\title{
Protecting-group-free syntheses of ent-kaurane diterpenoids: [3+2+1] cycloaddition/cycloalkenylation approach
}

Jin Wang, ${ }^{\dagger, \ddagger}, \square$ Benke Hong, ${ }^{\dagger, \ddagger, \square}$ Dachao Hu, ${ }^{\dagger, \ddagger}$ Yuichiro Kadonaga, ${ }^{\dagger, \ddagger}$ Ruyao Tang, ${ }^{\dagger, \ddagger}$ and Xiaoguang Lei ${ }^{\star},+, \neq, \S$

†Beijing National Laboratory for Molecular Sciences, Key Laboratory of Bioorganic Chemistry and Molecular Engineering of Ministry of Education, College of Chemistry and Molecular Engineering, Peking University, Beijing 100871, China

‡Department of Chemical Biology, Synthetic and Functional Biomolecules Center, Peking University, Beijing 100871, China

§Peking-Tsinghua Center for Life Sciences, Peking University, Beijing 100871, China.

\section{Supporting Information}

\begin{tabular}{|l|l|}
\hline \multicolumn{2}{|c|}{ Table of Contents } \\
\hline 1. General information & $\mathrm{S} 2$ \\
\hline $\begin{array}{l}\text { 2. Supporting Tables } \\
\text { 2.1 Model study of catalytic enantioselective conjugate addition } \\
\text { 2.2 Optimization of the Rh-catalyzed [3+2+1] cycloaddition } \\
\text { 2.3 Reaction screening of the Pd-mediated cycloalkenylation } \\
\text { 2.4 Optimization for diastereoselective ketone reduction of 17 } \\
\text { 2.5 Reaction screening of the hydrongenation }\end{array}$ & $\begin{array}{l}\text { S3-S6 } \\
\text { S7-S8 } \\
\text { S9-S11 } \\
\text { S12-S13 } \\
\text { S14-S15 }\end{array}$ \\
\hline 3. Comparison of natural and synthetic 2, 22 and 24 & S16-S22 \\
\hline 4. Substrate synthesis for the Rh-catalyzed [3+2+1] cycloaddition & S23-S33 \\
\hline 5. Experimental procedures for Secheme 2 & S34-S40 \\
\hline 6. Experimental procedures for Secheme 3 & S41-S46 \\
\hline 7. NMR spectra & S47-S110 \\
\hline 8. X-Ray crystallographic data & $\mathrm{S} 111-\mathrm{S} 119$ \\
\hline 9. References & $\mathrm{S} 120$ \\
\hline
\end{tabular}




\section{General information}

NMR spectra were recorded on a Varian $400 \mathrm{MHz}$ spectrometer, Bruker $400 \mathrm{MHz}$ NMR spectrometer (ARX400) and Bruker $400 \mathrm{MHz}$ NMR spectrometer (AVANCE III) at ambient temperature with $\mathrm{CDCl}_{3}$ as the solvent unless otherwise stated. Chemical shifts are reported in parts per million relative to $\mathrm{CDCl} 3\left({ }^{1} \mathrm{H}, \delta 7.26 ;{ }^{13} \mathrm{C}, \delta 77.00\right)$. Data for ${ }^{1} \mathrm{H}$ NMR are reported as follows: chemical shift, integration, multiplicity $(s=$ singlet, $d=$ doublet, $t=$ triplet, $q=$ quartet, quint = quintet, sixt $=$ sixtet, $\mathrm{m}=$ multiplet) and coupling constants. Infrared spectra were recorded on a Thermo Fisher FT-IR200 spectrophotometer. High-resolution mass spectra were obtained at Peking University Mass Spectrometry Laboratory using a Bruker APEX Flash chromatography. Analytical thin layer chromatography was performed using $0.25 \mathrm{~mm}$ silica gel $60-\mathrm{F}$ plates, using $254 \mathrm{~nm}$ UV light as the visualizing agent and a solution of phosphomolybdic acid and heat as developing agents. Flash chromatography was performed using 200-400 mesh silica gel. Yields refer to chromatographically and spectroscopically pure materials, unless otherwise stated. The Xray diffraction data was collected at Peking University. Chiral HPLC analysis was performed on an Agilent 1200 series. All reagents were used as supplied by Sigma-Aldrich, J\&K, Alfa Aesar Chemicals, TCl. Tetrahydrofuran and diethyl ether were distilled from sodium/ benzophenone ketyl prior to use; the other solvents were distilled from calcium hydride unless otherwise noted. All reactions were carried out in oven-dried glassware under an argon atmosphere unless otherwise noted. 


\section{Supporting Tables}

\subsection{Model study of catalytic enantioselective conjugate addition}

Table S1: Reaction screening of the copper-catalyzed asymmertric conjugate addition ${ }^{a}$
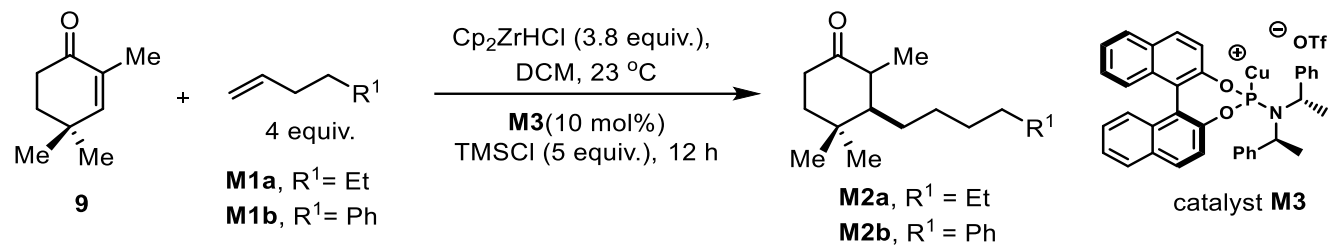

\begin{tabular}{|c|c|c|c|c|}
\hline entry & substrate & changes from "Standard Conditions" & Yield $^{b}\left(\right.$ d.r. $\left.{ }^{c}\right)$ & e.e. $(\%)^{d}$ \\
\hline 1 & M1a & 1.0 equiv $\mathrm{CuBr} \cdot \mathrm{Me}_{2} \mathrm{~S}$ instead of $\mathbf{M} 3$ & $65(2: 1)$ & -e \\
\hline 2 & M1a & None & $44(2: 1)$ & - \\
\hline 3 & M1b & 1.0 equiv $\mathrm{CuBr} \cdot \mathrm{Me}_{2} \mathrm{~S}$ instead of $\mathbf{M} 3$ & $65(3: 1)$ & 0 \\
\hline 4 & M1b & None & $20(3: 1)$ & 23 \\
\hline
\end{tabular}

aStandard conditions: substrate $\mathbf{M} 1 \mathbf{a}$ or $\mathbf{M} 1 \mathbf{b}$ (1.0 mmol, 4 equiv), $\mathrm{Cp}_{2} \mathrm{ZrHCl}$ (0.94 mmol, 3.75 equiv), DCM (0.5 mL), copper catalyst M3 (0.025 mmol, 0.1 equiv.), enone 9 (0.25 mmol, 1 equiv), TMSCI (1.25 mmol, 5 equiv.), $23^{\circ} \mathrm{C}, 12 \mathrm{~h}$. blsolated yields. ${ }^{c}$ Determined by ${ }^{1} \mathrm{C}-\mathrm{NMR}$ analysis or HPLC. dDetermined by chiral HPLC. eM2a could not react with (+)-(R,R)-DPEN, which was usually used to determine the enatiomeric purity of substituted cyclohexanones. ${ }^{1}$

General procedure: Copper catalyst $\mathbf{M} 3$ was prepared according to literature ${ }^{2}$ and used in our previous total synthesis of (+)-jungermatrobrunin $A .{ }^{3}$ To a stirred solution of alkene substrate $\mathbf{M} 1 \mathbf{a}$ (127 $\mu \mathrm{L}, 1.0 \mathrm{mmol}, 4$ equiv) or M1b (132 $\mathrm{LL}, 1.0 \mathrm{mmol}, 4$ equiv) in $0.5 \mathrm{~mL}$ dry dichloromethane was added $\mathrm{Cp}_{2} \mathrm{ZrHCl}$ (241 mg, $0.94 \mathrm{mmol}, 3.75$ equiv.) at $23^{\circ} \mathrm{C}$ and stirred for $1 \mathrm{~h}$, then copper catalyst M3 (19 mg, $0.025 \mathrm{mmol}, 0.1$ equiv.) or $\mathrm{CuBr} \bullet \mathrm{Me}_{2} \mathrm{~S}$ (51.4 mg, $0.25 \mathrm{mmol}, 1.0$ equiv) was added and stirred for additional $10 \mathrm{~min}$. Then enone $9(34.5 \mu \mathrm{L}, 0.25 \mathrm{mmol}, 1.0$ equiv.) was added dropwise. 5 min later, chlorotrimethylsilane ( $129 \mu \mathrm{L}, 1.25 \mathrm{mmol}, 5.0$ equiv.) was added. After $12 \mathrm{~h}$, the excess reagents were quenched by saturated aqueous $\mathrm{NaHCO}_{3}$ solution $(2 \mathrm{~mL})$, the resulting mixture was extracted with $\mathrm{Et}_{2} \mathrm{O}(2 \mathrm{~mL} \times 3)$, washed with brine $(2 \mathrm{~mL})$, the combined organic phases were dried over anhydrous $\mathrm{MgSO}_{4}$, concentrated in vacuo to afford a crude oil, which was purified by flash chromatography (Petroleum ether/ Diethyl ether $=80 / 1$ ) to afford $\mathbf{M} 2 \mathbf{a}$ or $\mathbf{M} 2 \mathbf{b}$ as colorless oil.

Data of M2a: ${ }^{1} \mathrm{H}$ NMR (400 MHz, $\left.\mathrm{CDCl}_{3}\right) \delta 2.47$ (td, $\left.J=13.9,6.2 \mathrm{~Hz}, 1 \mathrm{H}\right), 2.26$ (dq, $J=14.4,7.1$ $\mathrm{Hz}, 2 \mathrm{H}), 1.69$ (ddd, $J=13.5,6.2,2.7 \mathrm{~Hz}, 1 \mathrm{H}), 1.58$ (td, $J=13.7,4.4 \mathrm{~Hz}, 2 \mathrm{H}), 1.48-1.40(\mathrm{~m}, 1 \mathrm{H})$, 
$1.25(\mathrm{~m}, 14 \mathrm{H}), 1.05(\mathrm{~m}, 6 \mathrm{H}), 1.01-0.98(\mathrm{~m}, 3 \mathrm{H}), 0.97(\mathrm{~s}, 3 \mathrm{H}), 0.87(\mathrm{~m}, 4 \mathrm{H})$;

${ }^{13} \mathrm{C}$ NMR $\left(100 \mathrm{MHz}, \mathrm{CDCl}_{3}\right) \delta$ 213.8, 54.0, 47.2, 41.4, 38.2, 34.3, 31.7, 31.2, 31.0, 29.8, 29.3, 22.7, 19.6, 14.1, 12.6;

IR (film, cm-1) 2957, 2929, 2858, 1712, 1469, 1389, 1368,1152, 1009, 912;

HRMS(ESI) $[\mathrm{M}+\mathrm{H}]^{+}$calculated for $\mathrm{C}_{15} \mathrm{H}_{29} \mathrm{O}: 225.2213$, found: 225.2217 .

TLC: $\mathrm{Rf}=0.50($ Petroleum ether/Ethyl acetate $=20 / 1)$.

Data of M2b: ${ }^{1} \mathrm{H}$ NMR (400 MHz, $\left.\mathrm{CDCl}_{3}\right)$ ס 7.30-7.26(m, 2H), 7.19-7.17 (m, 3H), $2.61(\mathrm{t}, \mathrm{J}=7.9 \mathrm{~Hz}$, $2 \mathrm{H}$ ), $2.47(\mathrm{td}, J=14.2,6.1 \mathrm{~Hz}, 1 \mathrm{H}), 2.31-2.22(\mathrm{~m}, 2 \mathrm{H}), 1.69$ (ddd, $J=13.4,6.1,2.6 \mathrm{~Hz}, 1 \mathrm{H}), 1.63-$ $1.52(\mathrm{~m}, 4 \mathrm{H}), 1.52-1.37(\mathrm{~m}, 2 \mathrm{H}), 1.31(\mathrm{dq}, J=12.5,5.5 \mathrm{~Hz}, 2 \mathrm{H}), 1.20(\mathrm{td}, J=9.4,8.9,3.4 \mathrm{~Hz}, 1 \mathrm{H})$, 1.13-1.06 (m, 1H), 1.04-1.03 (m, 6H), 1.00-0.98(t, J = 0.99 Hz, 2H), $0.97(\mathrm{~s}, 3 \mathrm{H})$.

${ }^{13} \mathrm{C} \mathrm{NMR}\left(100 \mathrm{MHz}, \mathrm{CDCl}_{3}\right) \delta 213.7,142.5,128.2,125.6,53.9,47.2,41.3,38.2,35.8,34.3,31.9$, $30.9,30.8,29.4,19.6,12.6$;

IR (film, cm-1) 2935, 2859, 1710, 1603, 1496, 1389 1152, 1009, 789;

HRMS(ESI) $[\mathrm{M}+\mathrm{H}]^{+}$calculated for $\mathrm{C}_{19} \mathrm{H}_{29} \mathrm{O}: 273.2213$, found: 273.2205 ;

TLC: $\mathrm{Rf}=0.30($ Petroleum ether/Ethyl acetate $=20 / 1)$. 
Table S2: Reaction screening of the tandem Michael-methylation reaction

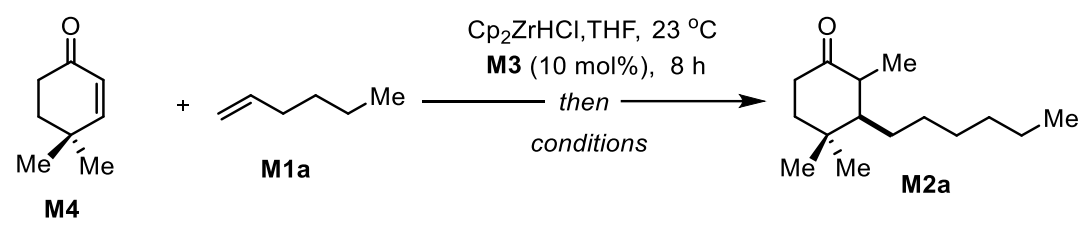

\begin{tabular}{lll}
\hline entry & Conditions & yield \\
\hline 1 & $\mathrm{CH}_{3} \mathrm{l}(10$ equiv.) & trace \\
2 & MeLi (4 equiv), HMPA (10 equiv), Mel (10 equiv.), $23^{\circ} \mathrm{C}$ & $23 \%$ \\
3 & MeLi (4 equiv), HMPA (10 equiv), Mel (20 equiv.), $23^{\circ} \mathrm{C}$ & $25 \%$ \\
4 & MeLi (4 equiv), HMPA (10 equiv), Mel (10 equiv.) $60^{\circ} \mathrm{C}$ & Complex mixture \\
\hline
\end{tabular}

General Procedure: To a stirred solution of alkene substrate M1a (127 $\mu \mathrm{L}, 1.0 \mathrm{mmol}, 2$ equiv) in $0.5 \mathrm{~mL}$ dry THF was added $\mathrm{Cp}_{2} \mathrm{ZrHCl}\left(206 \mathrm{mg}, 0.8 \mathrm{mmol}, 2\right.$ equiv.) at $23^{\circ} \mathrm{C}$ and stirred for $1 \mathrm{~h}$, then copper catalyst M3 (30 mg, $0.04 \mathrm{mmol}, 0.1$ equiv.) was added and stirred for additional $10 \mathrm{~min}$. Then enone M4 (50 $\mu \mathrm{L}, 0.4 \mathrm{mmol}, 1.0$ equiv.) was added dropwise. After $12 \mathrm{~h}$, for entry 1 , Mel (10 equiv.) was added. For entry $2-4$, the reaction mixture was cooled to $-78{ }^{\circ} \mathrm{C}$, MeLi $(1 \mathrm{~mL}, 1.6 \mathrm{mmol}$, 1.6 $\mathrm{M}$ in THF, 4 equiv) and HMPA (704 uL, $4 \mathrm{mmol}, 10$ equiv.) were added. After stirring at $-78{ }^{\circ} \mathrm{C}$ for $2 \mathrm{~h}$, Mel ( $250 \mathrm{uL}, 4 \mathrm{mmol}, 10$ equiv. or $500 \mathrm{uL}, 8 \mathrm{mmol}, 20$ equiv.) was added. Then the reaction mixture was stirred at indicated temperature. After another $12 \mathrm{~h}$, the excess reagents were quenched by saturated aqueous $\mathrm{NaHCO}_{3}$ solution $(2 \mathrm{~mL})$, the resulting mixture was extracted with $\mathrm{Et}_{2} \mathrm{O}(2 \mathrm{~mL} \times 3)$, washed with brine $(2 \mathrm{~mL})$, the combined organic phases were dried over anhydrous $\mathrm{MgSO}_{4}$, concentrated in vacuo to afford a crude oil, which was purified with flash column chromatography to afford corresponding product. 
Table S3: Reaction screening of the 2-step Michael-methylation reaction

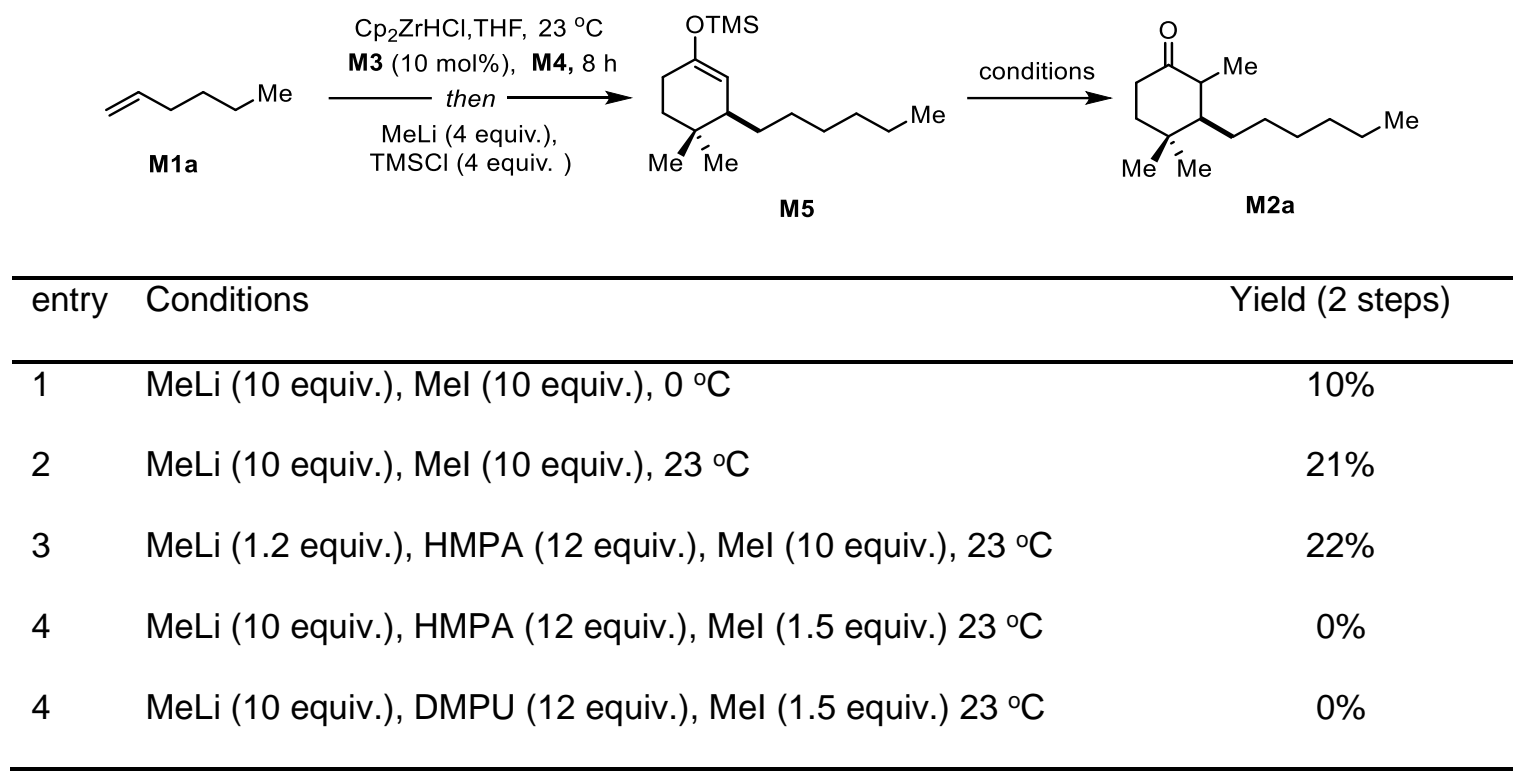

General procedure: To a stirred solution of alkene substrate M1a (2 equiv.) in $0.5 \mathrm{~mL}$ dry THF was added $\mathrm{Cp}_{2} \mathrm{ZrHCl}$ ( 2 equiv.) at $23^{\circ} \mathrm{C}$ and stirred for $1 \mathrm{~h}$, then copper catalyst $\mathbf{M} 3$ ( 0.1 equiv.) was added and stirred for additional $10 \mathrm{~min}$. Then enone M4 (1.0 equiv.) was added dropwise. After 12 $\mathrm{h}$, the reaction mixture was cooled to $-78^{\circ} \mathrm{C}$, MeLi (4 equiv) was added. After stirring at $-78{ }^{\circ} \mathrm{C}$ for $2 \mathrm{~h}, \mathrm{TMSCl}$ (10 equiv.) was added. Then the reaction mixture was allowed to warm to $23^{\circ} \mathrm{C}$. After another $12 \mathrm{~h}$, the excess reagents were quenched by saturated aqueous $\mathrm{NaHCO}_{3}$ solution, the resulting mixture was extracted with $\mathrm{Et}_{2} \mathrm{O}$, washed with brine, the combined organic phases were dried over anhydrous $\mathrm{MgSO}_{4}$, concentrated in vacuo to afford a crude oil, which was filtered through a pad of silica gel $\left(0.1 \% \mathrm{Et}_{3} \mathrm{~N}\right.$ neutralized) quickely to afford M5. M5 is very unstable, which was quickly used in next step. To an ice-cooled solution of M5 in dry THF were added MeLi (equiv. as indicated) and HMPA (12 equiv.) or DMPU (12 equiv.). The resulting solution was stirred for a futher $0.5 \mathrm{~h}$ at $0^{\circ} \mathrm{C}$. Then Mel (equiv. as indicated) was added and strirred at indicated temperature. After 12 hours, excess reagents were quench with saturated aqueous $\mathrm{NaHCO}_{3}$ solution, the resulting mixture was extracted with EA, washed with brine, the combined organic phases were dried over anhydrous $\mathrm{Na}_{2} \mathrm{SO}_{4}$, concentrated in vacuo and purified with flash column chromatography to afford the corresponding product. 


\subsection{Optimization of the Rh-catalyzed [3+2+1] cycloaddition}

Table S4: Reaction screening of the Rh-catalyzed [3+2+1] cycloadditiona

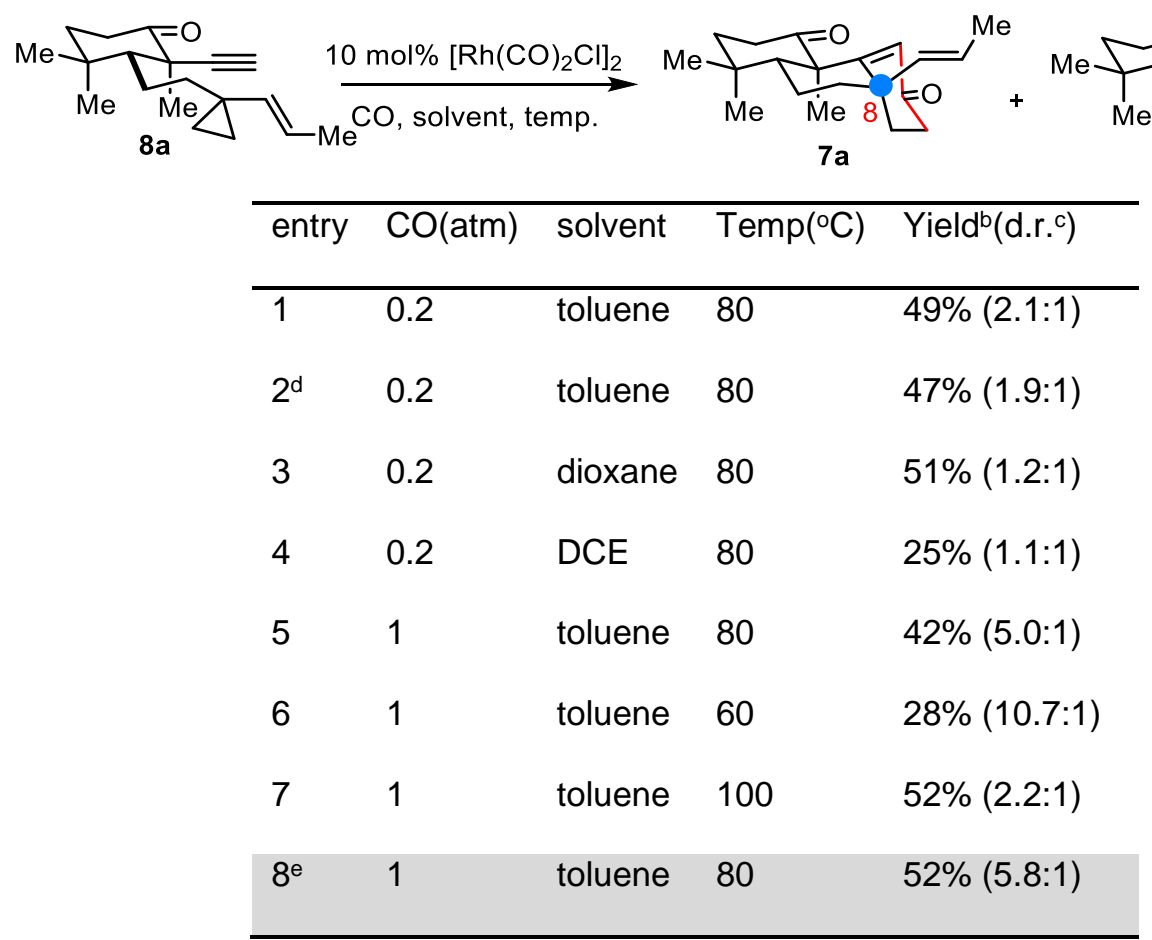

aUnless state otherwise, the reactions were performed with $8 \mathrm{a}(0.055 \mathrm{mmol})$ and $10 \mathrm{~mol} \%$ $\left[\mathrm{Rh}(\mathrm{CO})_{2} \mathrm{Cl}\right]_{2}$ in solvent $(1 \mathrm{~mL})$ under a balloon of $\mathrm{CO}$ for $18 \mathrm{~h}$. blsolated combined yields. 'Determined by ${ }^{1} \mathrm{H}-\mathrm{NMR}$ analysis. d.r. $=7 \mathrm{a} / 7 \mathrm{a}$ ' $\mathrm{d}\left[\mathrm{Rh}(\mathrm{COD})_{2} \mathrm{Cl}\right]_{2}$ was used instead of $\left[\mathrm{Rh}(\mathrm{CO})_{2} \mathrm{Cl}\right]_{2}$. e20 mol\% $\left[\mathrm{Rh}(\mathrm{CO})_{2} \mathrm{Cl}\right]_{2}$ was used instead of $10 \mathrm{~m} \%\left[\mathrm{Rh}(\mathrm{CO})_{2} \mathrm{Cl}\right]_{2}$.

General procedure: A solution of $8 \mathrm{a}(15 \mathrm{mg}, 0.055 \mathrm{mmol})$ and $\left[\mathrm{Rh}(\mathrm{CO}){ }_{2} \mathrm{Cl}\right]_{2}(2.1 \mathrm{mg}, 0.0055 \mathrm{mmol}$, 0.1 equiv. or $4.2 \mathrm{mg}, 0.011 \mathrm{mmol}, 0.2$ equiv.) in anhydrous solvents ( $1 \mathrm{~mL}$ ) was degassed by bubbling $\mathrm{CO}$ or $\mathrm{CO} / \mathrm{N}_{2}$ (balloon pressured mixed gas of $\mathrm{CO}$ and $\mathrm{N}_{2}$ ) for $10 \mathrm{~min}$. Then the reaction mixture was immersed in an $80^{\circ} \mathrm{C}$ (or $60^{\circ} \mathrm{C}$ or $100{ }^{\circ} \mathrm{C}$ ) oil bath and stirred under the above atmosphere. When TLC indicated the disappearance of the starting material, the reaction mixture was cooled to $23^{\circ} \mathrm{C}$ and concentrated in vacuo. The crude mixture was analyzed by ${ }^{1} \mathrm{H}$ NMR to determine the diastereoisomeric ratio and submitted to flash column chromatography on silica gel to afford the corresponding product.

Data of 7a: ${ }^{1} \mathrm{H}$ NMR (400 MHz, $\left.\mathrm{CDCl}_{3}\right) \delta 6.25(\mathrm{~s}, 1 \mathrm{H}), 5.42-5.27(\mathrm{~m}, 2 \mathrm{H}), 2.68$ (ddd, $J=13.6,10.1$, $4.9 \mathrm{~Hz}, 1 \mathrm{H}), 2.51-2.39(\mathrm{~m}, 1 \mathrm{H}), 2.40-2.27(\mathrm{~m}, 2 \mathrm{H}), 2.17(\mathrm{dt}, J=11.4,8.5 \mathrm{~Hz}, 1 \mathrm{H}), 1.92-1.86(\mathrm{~m}$, $1 \mathrm{H}), 1.85-1.81(\mathrm{~m}, 1 \mathrm{H}), 1.80-1.75(\mathrm{~m}, 1 \mathrm{H}), 1.74-1.69(\mathrm{~m}, 3 \mathrm{H}), 1.64(\mathrm{dd}, J=3.3,1.3 \mathrm{~Hz}, 3 \mathrm{H}), 1.61-$ $1.58(\mathrm{~m}, 1 \mathrm{H}), 1.57-1.51(\mathrm{~m}, 1 \mathrm{H}), 1.44(\mathrm{~s}, 3 \mathrm{H}), 1.04(\mathrm{~s}, 3 \mathrm{H}), 0.91(\mathrm{~s}, 3 \mathrm{H})$;

${ }^{13} \mathrm{C} \mathrm{NMR}\left(100 \mathrm{MHz}, \mathrm{CDCl}_{3}\right)$ ठ 211.3, 200.4, 167.0, 134.8, 129.9, 126.7, 53.4, 42.8, 41.9, 40.5, 37.9, $36.1,33.0,32.9,32.7,31.5,24.8,23.0,17.9,17.6$; 
IR (film, cm-1) 2948, 1711, 1669, 1448, 1334 1256, 980;

HRMS(ESI) $[\mathrm{M}+\mathrm{H}]^{+}$calculated for $\mathrm{C}_{20} \mathrm{H}_{29} \mathrm{O}_{2}: 301.2162$, found: 301.2167 .

TLC: $\mathrm{Rf}=0.20($ Petroleum ether/Ethyl acetate $=8 / 1)$.

Data of 7a': ${ }^{1} \mathrm{H}$ NMR $\left(400 \mathrm{MHz}, \mathrm{CDCl}_{3}\right) \delta 6.26(\mathrm{~s}, 1 \mathrm{H}), 5.54(\mathrm{~m}, 1 \mathrm{H}), 5.41(\mathrm{dd}, J=15.8,1.3 \mathrm{~Hz}$, 1H), 2.63 (ddd, $J=14.6,13.6,4.6 \mathrm{~Hz}, 1 \mathrm{H}$ ), 2.49 (ddd, $J=17.3,14.7,5.2 \mathrm{~Hz}, 1 \mathrm{H}$ ), 2.30 (ddd, $J=$ $13.5,4.5,2.9 \mathrm{~Hz}, 1 \mathrm{H}), 2.25-2.14(\mathrm{~m}, 2 \mathrm{H}), 1.92-1.82(\mathrm{~m}, 1 \mathrm{H}), 1.81-1.74(\mathrm{~m}, 2 \mathrm{H}), 1.74-1.69(\mathrm{~m}, 3 \mathrm{H})$, 1.69 -1.66 (m, 1H), 1.65-1.59 (m, 2H), 1.51-1.42 (m, 2H), $1.31(\mathrm{~s}, 3 \mathrm{H}), 1.06(\mathrm{~s}, 3 \mathrm{H}), 0.95(\mathrm{~s}, 3 \mathrm{H})$;

${ }^{13} \mathrm{C} \mathrm{NMR}\left(100 \mathrm{MHz}, \mathrm{CDCl}_{3}\right) \delta$ 214.3, 200.8, 164.6, 134.8, 126.5, 126.2, 54.0, 50.9, 42.0, 41.2, 39.9, $37.5,36.4,33.1,32.2,31.0,25.8,23.8,19.7,18.0$;

IR (film, cm-1) 2931, 1707, 1668, 1467, 1324 1262, 1018, 975;

HRMS(ESI) $[\mathrm{M}+\mathrm{H}]^{+}$calculated for $\mathrm{C}_{20} \mathrm{H}_{29} \mathrm{O}_{2}: 301.2162$, found: 301.2157 ;

TLC: $\mathrm{Rf}=0.20($ Petroleum ether/Ethyl acetate $=8 / 1)$. 


\subsection{Optimization of the Pd-mediated cycloalkenylation}

Table S5: Reaction screening of the Pd-mediated cycloalkenylation
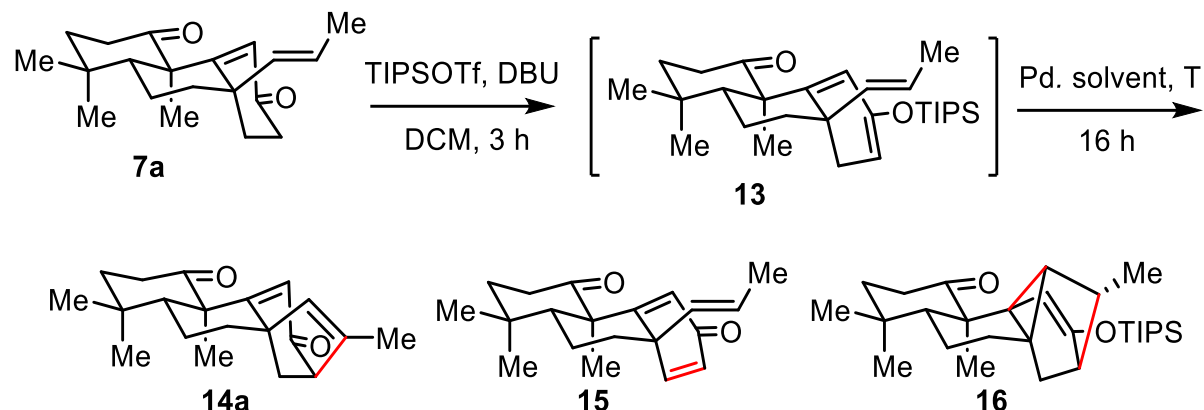

\begin{tabular}{|c|c|c|c|c|c|c|}
\hline \multirow[t]{2}{*}{ entry } & \multirow{2}{*}{$\begin{array}{l}\mathrm{Pd} \\
\text { source }\end{array}$} & \multirow{2}{*}{$\begin{array}{l}\text { Temp } \\
\left({ }^{\circ} \mathrm{C}\right)\end{array}$} & \multirow[t]{2}{*}{ solvent } & \multicolumn{3}{|c|}{ conversion $^{\mathrm{b}}$} \\
\hline & & & & $14 a$ & 15 & 16 \\
\hline 1 & $\mathrm{Pd}(\mathrm{OAc})_{2}$ & 50 & DMSO & $24 \%$ & $65 \%$ & $8 \%$ \\
\hline 2 & $\mathrm{PdCl}_{2}$ & 50 & DMSO & $11 \%$ & $89 \%$ & $0 \%$ \\
\hline 3 & $\mathrm{Pd}(\mathrm{TFA})_{2}$ & 50 & DMSO & $0 \%$ & $63 \%$ & $0 \%$ \\
\hline 4 & $\mathrm{Pd}(\mathrm{OAc})_{2}$ & 50 & Dioxane & $42 \%$ & $12 \%$ & $33 \%$ \\
\hline 5 & $\mathrm{Pd}(\mathrm{OAc})_{2}$ & 50 & $\mathrm{MeCN}$ & $22 \%$ & $78 \%$ & $0 \%$ \\
\hline 6 & $\mathrm{Pd}(\mathrm{OAc})_{2}$ & 50 & DMF & $23 \%$ & $63 \%$ & $0 \%$ \\
\hline 7 & $\mathrm{Pd}(\mathrm{OAc})_{2}$ & 50 & $t-\mathrm{BuOH}$ & $40 \%$ & $18 \%$ & $26 \%$ \\
\hline 8 & $\mathrm{Pd}(\mathrm{OAc})_{2}$ & 50 & THF & $39 \%$ & $12 \%$ & $26 \%$ \\
\hline 9 & $\mathrm{Pd}(\mathrm{OAc})_{2}$ & 50 & glyme & $33 \%$ & $10 \%$ & $27 \%$ \\
\hline $9^{c}$ & $\mathrm{Pd}(\mathrm{OAc})_{2}$ & 50 & Dioxane & $50 \%$ & $23 \%$ & $13 \%$ \\
\hline $10^{c}$ & $\mathrm{Pd}(\mathrm{OAc})_{2}$ & 35 & Dioxane & $57 \%$ & $20 \%$ & $12 \%$ \\
\hline $10^{c}$ & $\mathrm{Pd}(\mathrm{OAc})_{2}$ & 23 & Dioxane & $79 \%$ & $7 \%$ & $9 \%$ \\
\hline $11^{d}$ & $\mathrm{Pd}(\mathrm{OAc})_{2}$ & 23 & Dioxane & $0 \%$ & $0 \%$ & $0 \%$ \\
\hline 12 & - & 50 & Dioxane & $0 \%$ & $0 \%$ & $0 \%$ \\
\hline $13^{e}$ & $\mathrm{Pd}(\mathrm{OAc})_{2}$ & 50 & Dioxane & $16 \%$ & $16 \%$ & $68 \%$ \\
\hline
\end{tabular}

aReaction conditions: $7 \mathrm{a}(6.7 \mu \mathrm{mol}), \mathrm{DBU}$ (2 equiv.), TIPSOTf (1.8 equiv.), $\mathrm{CH}_{2} \mathrm{Cl}_{2}(0.3 \mathrm{~mL}), 3 \mathrm{~h}$

then Pd salt (1 equiv.), solvent ( $0.3 \mathrm{~mL}), 16 \mathrm{~h}$. ${ }^{b}$ Determined by ${ }^{1} \mathrm{HNMR}$ analysis. ${ }^{\mathrm{c}} 5$ equiv.

$\mathrm{Pd}(\mathrm{OAc})_{2}$ was used instead of 1 equiv $\mathrm{Pd}(\mathrm{OAc})_{2} .{ }^{\mathrm{d}} 0.2$ equiv $\mathrm{Pd}(\mathrm{OAc})_{2}$ was used under a balloon of $\mathrm{O}_{2}$ instead of 1 equiv $\mathrm{Pd}(\mathrm{OAc})_{2 .}{ }^{e}$ Microwave was used.

General procedure: To a solution of $7 \mathrm{a}(2 \mathrm{mg}, 6.7 \mu \mathrm{mol})$ in dry $\mathrm{CH}_{2} \mathrm{Cl}_{2}(0.3 \mathrm{~mL})$ at $23^{\circ} \mathrm{C}$ under $\mathrm{Ar}$ was added DBU ( $2 \mu \mathrm{L}, 13.5 \mu \mathrm{mol}, 2$ equiv.) and TIPSOTf ( $3 \mu \mathrm{L}, 12 \mu \mathrm{mol}, 1.8$ equiv.). The mixture was stirred until full conversion was observed by TLC. Then another solvent $(0.3 \mathrm{~mL})$ and Pd salts were added. The reaction mixture was immersed in a $50^{\circ} \mathrm{C}$ (or $35^{\circ} \mathrm{C}$ or $23^{\circ} \mathrm{C}$ ) oil bath and stirred for $16 \mathrm{~h}$. After quenching with water, the mixture was extracted with ether, and the combined organic layers were washed with brine, dried over $\mathrm{Na}_{2} \mathrm{SO}_{4}$, filtered and concentrated in vacuo. The crude 
reaction mixtures were analyzed by ${ }^{1} \mathrm{H}$ NMR to determine the conversion rate for each product.

Data of 14a: ${ }^{1} \mathrm{H} \mathrm{NMR}\left(400 \mathrm{MHz}, \mathrm{CDCl}_{3}\right) \delta 6.00(\mathrm{~s}, 1 \mathrm{H}), 5.22(\mathrm{~d}, J=1.0 \mathrm{~Hz}, 1 \mathrm{H}), 3.04(\mathrm{~d}, J=3.0 \mathrm{~Hz}$, $1 \mathrm{H}), 2.60-2.50(\mathrm{~m}, 1 \mathrm{H}), 2.37-2.32(\mathrm{~m}, 2 \mathrm{H}), 2.26$ (ddd, $J=14.1,6.4,4.4 \mathrm{~Hz}, 1 \mathrm{H}), 2.03-2.00(\mathrm{~m}, 1 \mathrm{H})$, 1.97-1.93 (m, 1H), 1.92-1.86 (m, 1H), 1.85-1.78 (m, 2H), $1.76(\mathrm{~d}, J=1.2 \mathrm{~Hz}, 3 \mathrm{H}), 1.75-1.67(\mathrm{~m}$, $1 \mathrm{H}), 1.64-1.56(\mathrm{~m}, 1 \mathrm{H}), 1.35(\mathrm{~s}, 3 \mathrm{H}), 1.01(\mathrm{~s}, 3 \mathrm{H}), 0.91(\mathrm{~s}, 3 \mathrm{H})$;

${ }^{13} \mathrm{C} \mathrm{NMR}\left(100 \mathrm{MHz}, \mathrm{CDCl}_{3}\right) \delta 212.9,199.9,172.0,143.3,139.5,115.0,61.2,57.4,51.9,50.6,43.7$, $38.4,35.6,32.5,30.6,27.0,24.4,20.1,17.5,15.5$;

IR (film, cm-1) 2929, 1709, 1672, 1464, 1240;

HRMS(ESI) $[\mathrm{M}+\mathrm{H}]^{+}$calculated for $\mathrm{C}_{20} \mathrm{H}_{27} \mathrm{O}_{2}: 299.2006$, found: 299.2002;

TLC: $\mathrm{Rf}=0.29($ Petroleum ether/Ethyl acetate $=10 / 1)$.

Data of 15: ${ }^{1} \mathrm{H}$ NMR $\left(400 \mathrm{MHz}, \mathrm{CDCl}_{3}\right) \delta 6.59(\mathrm{~d}, J=1.2 \mathrm{~Hz}, 1 \mathrm{H}), 6.54(\mathrm{~d}, J=9.8 \mathrm{~Hz}, 1 \mathrm{H}), 5.99$ (dd, $J=9.7,1.2 \mathrm{~Hz}, 1 \mathrm{H}), 5.36-5.28(\mathrm{~m}, 2 \mathrm{H}), 2.61-2.51(\mathrm{~m}, 2 \mathrm{H}), 2.39-2.29(\mathrm{~m}, 1 \mathrm{H}), 2.17-2.09(\mathrm{~m}$, 1H), 1.95-1.84 (m, 1H), 1.80 (ddd, $J=14.6,11.0,4.1 \mathrm{~Hz}, 1 \mathrm{H}), 1.71-1.60(\mathrm{~m}, 3 \mathrm{H}), 1.59$ (d, $J=4.8$ $\mathrm{Hz}, 3 \mathrm{H}), 1.43$ (s, 3H), 1.04 (s, 3H), 1.02 (s, 3H);

${ }^{13} \mathrm{C}$ NMR $\left(100 \mathrm{MHz}, \mathrm{CDCl}_{3}\right) \delta 210.9,187.2,164.9,153.9,132.2,131.0,127.0,123.0,53.2,45.5$, $41.9,37.4,35.9,31.9,31.5,29.1,24.2,24.0,17.9,16.7$;

IR (film, cm-1) 2954, 1714, 1659, 1469, 1125, 864;

HRMS(ESI) $[\mathrm{M}+\mathrm{H}]^{+}$calculated for $\mathrm{C}_{20} \mathrm{H}_{27} \mathrm{O}_{2}: 299.2006$, found: 299.2007;

TLC: $\mathrm{Rf}=0.10($ Petroleum ether/Ethyl acetate $=7 / 1)$.

Data of 16: ${ }^{1} \mathrm{H}$ NMR $\left(600 \mathrm{MHz}, \mathrm{CDCl}_{3}\right) \delta 4.93(\mathrm{~d}, J=2.3 \mathrm{~Hz}, 1 \mathrm{H}), 2.61-2.53(\mathrm{~m}, 1 \mathrm{H}), 2.21$ (ddd, $J$ $=14.0,7.5,4.3 \mathrm{~Hz}, 1 \mathrm{H}), 2.06(\mathrm{q}, J=4.4 \mathrm{~Hz}, 1 \mathrm{H}), 2.01-1.96(\mathrm{~m}, 1 \mathrm{H}), 1.93(\mathrm{dd}, J=13.6,8.3 \mathrm{~Hz}, 1 \mathrm{H})$, 1.88-1.77 (m, 1H), 1.72 (ddd, $J=12.1,7.5,4.6 \mathrm{~Hz}, 1 \mathrm{H}), 1.60$ (ddd, $J=14.7,10.9,4.4 \mathrm{~Hz}, 1 \mathrm{H}$ ), 1.51-1.37 (m, 4H), $1.34(\mathrm{~s}, 3 \mathrm{H}), 1.20-1.10(\mathrm{~m}, 3 \mathrm{H}), 1.08$ (dd, J = 10.6, 7.2 Hz, 18H), $1.04(\mathrm{~s}, 3 \mathrm{H})$, $0.99(\mathrm{~d}, J=11.1 \mathrm{~Hz}, 1 \mathrm{H}), 0.94(\mathrm{~s}, 3 \mathrm{H}), 0.82(\mathrm{~d}, J=2.3 \mathrm{~Hz}, 1 \mathrm{H}), 0.80(\mathrm{~d}, J=6.6 \mathrm{~Hz}, 3 \mathrm{H})$.

${ }^{13} \mathrm{C}$ NMR $\left(151 \mathrm{MHz}, \mathrm{CDCl}_{3}\right) \delta 215.5,148.9,98.8,48.9,45.4,42.9,39.3,37.8,36.2,35.7,32.4$, $32.4,30.6,29.1,26.2,24.5,23.0,19.4,18.7,18.1,18.0,13.5,12.6$;

IR (film, $\mathrm{cm}^{-1}$ ) 2944, 2866, 1713, 1551, 1464, 1381,1228, 1003, 883, 894;

HRMS(ESI) $[\mathrm{M}+\mathrm{H}]^{+}$calculated for $\mathrm{C}_{29} \mathrm{H}_{49} \mathrm{O}_{2} \mathrm{Si}: 457.3496$, found: 457.3484 ;

TLC: $\mathrm{Rf}=0.87($ Petroleum ether/Ethyl acetate $=7 / 1)$.

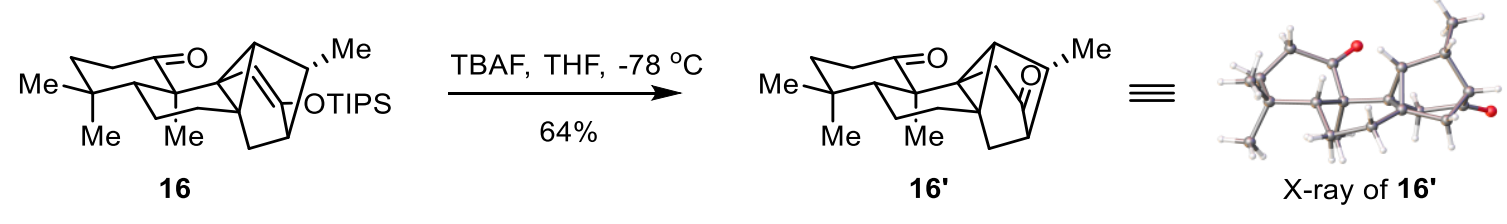

To a solution of $16(6.9 \mathrm{mg}, 0.015 \mathrm{mmol}, 1.0$ equiv.) in dry THF ( $3 \mathrm{~mL})$ at $-78{ }^{\circ} \mathrm{C}$ under Ar were added TBAF (1.0 M in THF, $23 \mu \mathrm{L}, 0.023 \mathrm{mmol}, 1.5$ equiv.) dropwise. The reation was stirred for 2 h. Then the excess reagents were quenched with a saturated aqueous solution of $\mathrm{NH}_{4} \mathrm{Cl}(2.0 \mathrm{~mL})$. 
The aqueous layer was extracted with $\mathrm{EA}(2 \times 3 \mathrm{~mL})$ and washed with brine $(2.0 \mathrm{~mL})$. The organic layer was then dried over anhydrous $\mathrm{Na}_{2} \mathrm{SO}_{4}$, filtered, and concentrated in vacuo. The residue was purified by flash chromatography on silica gel (Petroleum ether/acetone $=15 / 1)$ to afford 16' $(3.3$ $\mathrm{mg}, 73 \%)$ as a colorless solid.

Single crystals of $16^{\prime}$ ' suitable for X-ray crystallographic analysis were obtained by a single recrystallization at $23{ }^{\circ} \mathrm{C}$ using $n$-hexane/ $\mathrm{CHCl}_{3}$ as a solvent by slow evaporation. The relative configuration was determined by X-ray crystallographic analysis. See S111.

Data of 16': ' ${ }^{1} \mathrm{H}$ NMR $\left(500 \mathrm{MHz}, \mathrm{CDCl}_{3}\right) \delta 2.95(\mathrm{~d}, J=20.1 \mathrm{~Hz}, 1 \mathrm{H}), 2.55$ (ddd, $J=14.8,10.2,4.6$ $\mathrm{Hz}, 1 \mathrm{H}$ ), 2.47 (d, $J=20.0 \mathrm{~Hz}, 2 \mathrm{H}$ ), $2.28(\mathrm{t}, J=5.2 \mathrm{~Hz}, 1 \mathrm{H}), 2.21$ (ddd, $J=14.7,8.0,4.5 \mathrm{~Hz}, 1 \mathrm{H}$ ), 2.03-1.89 (m, 2H), 1.89-1.74 (m, 2H), 1.73 (d, $J=12.9 \mathrm{~Hz}, 1 \mathrm{H}$ ), 1.61 (ddd, $J=14.3,10.2,4.5 \mathrm{~Hz}$, $1 \mathrm{H}), 1.50-1.38(\mathrm{~m}, 2 \mathrm{H}), 1.33(\mathrm{dd}, J=11.8,2.9 \mathrm{~Hz}, 1 \mathrm{H}), 1.29(\mathrm{~s}, 3 \mathrm{H}), 1.10(\mathrm{~d}, J=3.5 \mathrm{~Hz}, 1 \mathrm{H}), 1.04$ (s, 3H), 1.04 (d, J = $7.9 \mathrm{~Hz}, 3 \mathrm{H}), 0.96(\mathrm{~s}, 3 \mathrm{H})$;

${ }^{13} \mathrm{C}$ NMR (126 MHz, CDCl $) \delta 215.7,212.2,52.4,48.9,45.4,38.8,37.6,36.8,36.2,35.9,32.5$, $32.230 .0,26.9,26.1,25.6,23.2,18.7,17.7,15.0$.

IR (film, cm-1) 2957, 2928, 2875, 1709, 1461, 1378, 1330, 1030, 733 ;

HRMS(ESI) $[\mathrm{M}+\mathrm{H}]^{+}$calculated for $\mathrm{C}_{20} \mathrm{H}_{29} \mathrm{O}_{2}: 301.2162$, found: 301.2161 ;

TLC: $\mathrm{Rf}=0.36($ Petroleum ether/actone $=9 / 1)$. 


\subsection{Optimization for diastereoselective ketone reduction of 17}

Table S6: Reaction screening of the reduction of 17

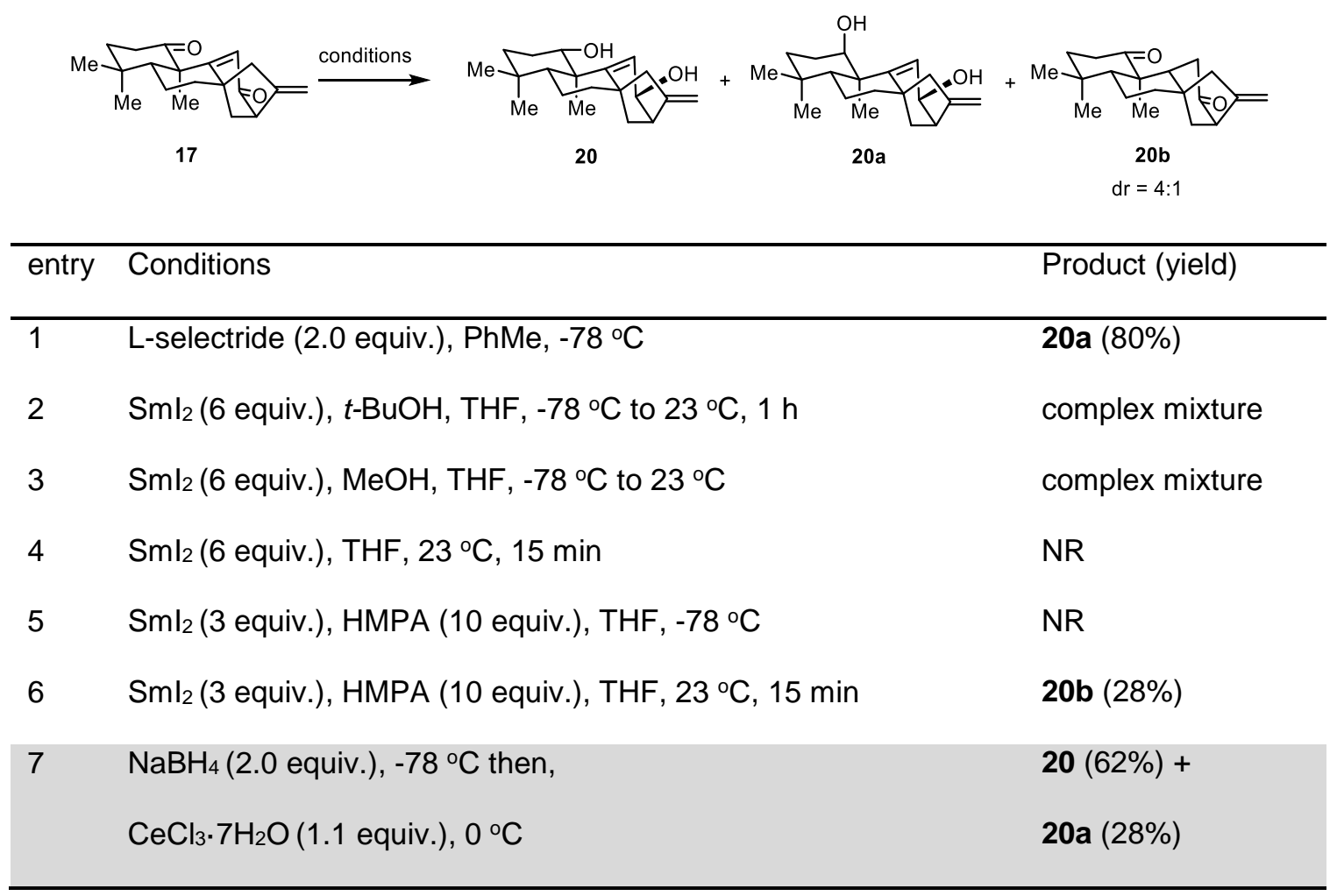

Procedure for entry 1: To a solution of $17(5 \mathrm{mg}, 0.167 \mathrm{mmol}, 1.0$ equiv.) in toluene $(1 \mathrm{~mL})$ was added L-selectride (42 uL, $1.0 \mathrm{M}$ in THF, $0.42 \mathrm{mmol}, 2.5$ equiv.) at $-78{ }^{\circ} \mathrm{C}$, the resulting mixture was stirred at this temperature for $2 \mathrm{~h}$. Then excess reagents were quenched with saturated $\mathrm{NaHCO}_{3}$ $(2 \mathrm{~mL})$, the resulting mixture was extracted with ethyl acetate $(3 \mathrm{~mL} \times 3)$, washed with brine $(3 \mathrm{~mL})$, the combined organic phases were dried over anhydrous $\mathrm{Na}_{2} \mathrm{SO}_{4}$, concentrated in vacuo to afford a crude oil, which was purified by flash chromatography (Petroleum ether/Ethyl acetate $=3 / 1$ ) to afford 20 a as a yellow oil (4 mg, $80 \%$ ).

Data of 20a: ${ }^{1} \mathrm{H}$ NMR (600 MHz, $\left.\mathrm{CDCl}_{3}\right) \delta 5.27(\mathrm{~s}, 1 \mathrm{H}), 5.08(\mathrm{~d}, \mathrm{~J}=12.8 \mathrm{~Hz}, 2 \mathrm{H}), 4.41-4.35(\mathrm{~m}$, 1H), 3.85-3.80 (m, 1H), $2.78(\mathrm{t}, \mathrm{J}=5.5 \mathrm{~Hz}, 1 \mathrm{H}), 2.52(\mathrm{~d}, \mathrm{~J}=16.1 \mathrm{~Hz}, 1 \mathrm{H}), 2.25(\mathrm{dt}, \mathrm{J}=16.1,2.7$ $\mathrm{Hz}, 1 \mathrm{H}), 1.93(\mathrm{~d}, \mathrm{~J}=12.0 \mathrm{~Hz}, 1 \mathrm{H}), 1.89-1.68(\mathrm{~m}, 8 \mathrm{H}), 1.59-1.58(\mathrm{~m}, 1 \mathrm{H}), 1.54-1.51(\mathrm{~m}, 1 \mathrm{H}), 1.13$ (dt, J = 13.1, 3.5 Hz, 1H), 1.10 (s, 3H), 0.92 (s, 3H), 0.88 (s, 3H).;

${ }^{13} \mathrm{C}$ NMR $\left(150 \mathrm{MHz}, \mathrm{CDCl}_{3}\right) \delta 155.6,151.0,119.2,110.1,70.7,70.7,48.9,47.4,46.3,44.4,42.9$, $37.2,34.6,33.9,32.6,28.6,24.2,23.5,21.3,17.2$.

IR (film, cm-1) 3417, 2937, 2859, 1457, 1389, 1064, 988, 908;

HRMS(ESI) $\left[\mathrm{M}+\mathrm{NH}_{4}\right]^{+}$calculated for $\mathrm{C}_{20} \mathrm{H}_{34} \mathrm{NO}_{2}: 320.2584$, found: 320.2581 ;

TLC: $\mathrm{Rf}=0.24($ Petroleum ether/Ethyl acetate $=4 / 1)$. 
Procedure for entry 6: To a solution of $17(35 \mathrm{mg}, 0.117 \mathrm{mmol}, 1.0$ equiv.) in THF (2 mL) and HMPA (203 uL, 1.17 mmol, 10 equiv.) was added Sml (3.5 mL, $0.1 \mathrm{M}$ in THF, $0.351 \mathrm{mmol}, 3$ equiv.) at $23{ }^{\circ} \mathrm{C}$, the resulting mixture was stirred at this temperature for $1 \mathrm{~h}$. Then excess reagents were quenched with saturated $\mathrm{NaHCO}_{3}(2 \mathrm{~mL})$, the resulting mixture was extracted with ethyl acetate (5 $\mathrm{mL} \times 3)$, washed with brine $(3 \mathrm{~mL})$, the combined organic phases were dried over anhydrous $\mathrm{Na}_{2} \mathrm{SO}_{4}$, concentrated in vacuo to afford a crude oil, which was purified by flash chromatography (Petroleum ether/Ethyl acetate $=4 / 1)$ to afford $20 \mathrm{~b}(10 \mathrm{mg}, 28 \%)$ as a yellow oil.

Data of 20b: ${ }^{1} \mathrm{H}$ NMR (600 MHz, $\left.\mathrm{CDCl}_{3}\right) \delta 5.00(\mathrm{~s}, 1 \mathrm{H}), 4.89(\mathrm{~s}, 1 \mathrm{H}), 3.21(\mathrm{~d}, \mathrm{~J}=4.9 \mathrm{~Hz}, 1 \mathrm{H}), 2.95$ (td, $J=13.4,5.8 \mathrm{~Hz}, 1 \mathrm{H}), 2.83(\mathrm{dd}, J=17.6,9.6 \mathrm{~Hz}, 1 \mathrm{H}), 2.48-2.43(\mathrm{~m}, 1 \mathrm{H}), 2.39-2.34(\mathrm{~m}, 1 \mathrm{H})$, 2.30 (dt, $J=6.3,3.6 \mathrm{~Hz}, 1 \mathrm{H}), 2.27(\mathrm{dd}, J=9.6,1.5 \mathrm{~Hz}, 1 \mathrm{H}), 2.23-2.16(\mathrm{~m}, 1 \mathrm{H}), 2.13-2.07(\mathrm{~m}, 1 \mathrm{H})$, 1.83-1.79 (m, 1H), 1.70-1.66 (m, 1H), 1.65-1.63 (m, 1H), 1.60 (ddd, J = 10.6, 5.3, 2.7 Hz, 3H), 1.55$1.52(\mathrm{~m}, 1 \mathrm{H}), 1.28(\mathrm{~s}, 3 \mathrm{H}), 1.22-1.20(\mathrm{~m}, 1 \mathrm{H}), 1.05(\mathrm{~s}, 3 \mathrm{H}), 0.93(\mathrm{~s}, 3 \mathrm{H})$;

${ }^{13} \mathrm{C}$ NMR $\left(150 \mathrm{MHz}, \mathrm{CDCl}_{3}\right)$ ठ 216.0, 211.9, 148.3, 108.0, 60.3, 57.1, 54.4, 48.4, 48.1, 43.8, 42.8, 39.7, 39.3, 38.2, 34.8, 33.3, 31.9, 29.7, 22.2, 20.3;

IR (film, cm ${ }^{-1}$ ) 2939, 1720, 1709, 1660, 1465, 1267, 887;

HRMS(ESI) $[\mathrm{M}+\mathrm{H}]^{+}$calculated for $\mathrm{C}_{20} \mathrm{H}_{29} \mathrm{O}_{2}: 301.2162$, found: 301.2167 ;

TLC: $\mathrm{Rf}=0.45($ Petroleum ether/Ethyl acetate $=5 / 1)$.

Procedure for entry 7: To a solution of $17(6.5 \mathrm{mg}, 0.02 \mathrm{mmol})$ in $\mathrm{MeOH}(2 \mathrm{~mL})$ was added $\mathrm{NaBH}_{4}$ (1.6 mg, $0.04 \mathrm{mmol}, 2.0$ equiv.) at $-78{ }^{\circ} \mathrm{C}$. After stirring for $3 \mathrm{~h}$ at $-78{ }^{\circ} \mathrm{C}, \mathrm{CeCl}_{3} \cdot 7 \mathrm{H}_{2} \mathrm{O}(13.7 \mathrm{mg}$, $0.0369 \mathrm{mmol}, 1.1$ equiv.) was added and the reaction mixture was stirring at $0{ }^{\circ} \mathrm{C}$ for $15 \mathrm{~min}$. The excess resgents were quenched by addition of saturated aqueous $\mathrm{NaHCO}_{3}(5 \mathrm{~mL})$ and the resulting mixture was extracted with ethyl acetate $(3 \times 5 \mathrm{~mL})$. The combined organic phases were washed with brine $(5 \mathrm{~mL})$, dried over $\mathrm{Na}_{2} \mathrm{SO}_{4}$, filterred and concentrated in vacuo. The residue was purified on silica gel chromatography (Petroleum ether/acetone $=15 / 1$ to $9 / 1)$ to provide alcohol $20(4.0 \mathrm{mg}$, $62 \%)$ and $20 \mathrm{a}(1.8 \mathrm{mg}, 28 \%)$ as colorless oil.

Data of ketone 20: ${ }^{1} \mathrm{H}$ NMR (400 MHz, CDCl $) \delta 6.09(\mathrm{~s}, 1 \mathrm{H}), 5.05(\mathrm{~s}, 1 \mathrm{H}), 5.00(\mathrm{~s}, 1 \mathrm{H}), 4.39$ (dd, $J=5.3,2.7 \mathrm{~Hz}, 1 \mathrm{H}), 3.68-3.58(\mathrm{~m}, 1 \mathrm{H}), 2.76(\mathrm{t}, J=5.4 \mathrm{~Hz}, 1 \mathrm{H}), 2.51(\mathrm{~d}, J=16.0 \mathrm{~Hz}, 1 \mathrm{H}), 2.26$ (dt, $J=16.1,2.6 \mathrm{~Hz}, 1 \mathrm{H}), 1.95-1.86(\mathrm{~m}, 1 \mathrm{H}), 1.83-1.72(\mathrm{~m}, 2 \mathrm{H}), 1.71-1.67(\mathrm{~m}, 1 \mathrm{H}), 1.64-1.62(\mathrm{~m}, 1 \mathrm{H})$, 1.60-1.57 (m, 2H), 1.47-1.44 (m, 1H), 1.41-1.35 (m, 1H), 1.34-1.27 (m, 2H), $1.10(\mathrm{~s}, 3 \mathrm{H}), 0.90(\mathrm{~s}$, $3 \mathrm{H}), 0.83(\mathrm{~s}, 3 \mathrm{H})$;

${ }^{13} \mathrm{C}$ NMR $\left(100 \mathrm{MHz}, \mathrm{CDCl}_{3}\right) \delta 157.6,151.3,120.0,109.1,78.3,70.6,50.4,48.5,46.1,43.9,43.7$, 43.3, 39.8, 33.6, 32.0, 29.9, 29.4, 20.8, 18.8, 17.6;

IR (film, cm-1) 3399, 2936, 1458, 1387, 1029, 911, 734;

HRMS(ESI) $[\mathrm{M}+\mathrm{Na}]^{+}$calculated for $\mathrm{C}_{20} \mathrm{H}_{30} \mathrm{NaO}_{2}$ : 325.2138, found: 325.2137;

TLC: $\mathrm{Rf}=0.31($ Petroleum ether/Ethyl acetate $=2 / 1)$. 


\subsection{Optimization of the diastereoselective hydrongenation}

Table S7: Reaction screening of the diastereoselective hydrongenation of 19/20 with various catalysts

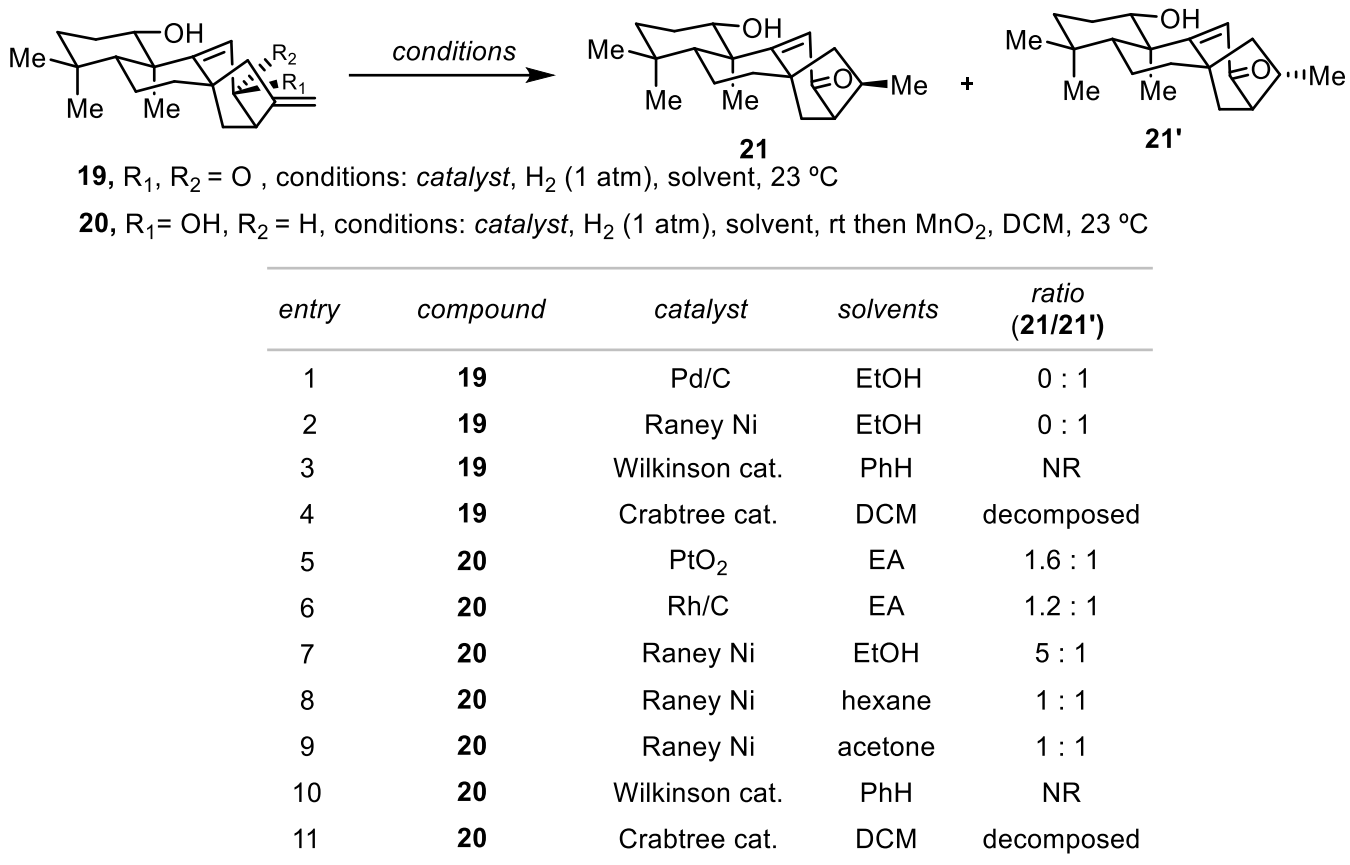

General procedure: To a solution of substrate in the solvent was added catalyst at $23^{\circ} \mathrm{C}$. This suspension was degassed at $-78^{\circ} \mathrm{C}$ and backfilled with $\mathrm{H}_{2}$ three times. After $12 \mathrm{~h}$, the reaction was concentrated in vacuo. For 19 , the crude reaction mixtures were analyzed by ${ }^{1} \mathrm{H}$ NMR to determine the ratio. For 20 , the residue was redissolved in $\mathrm{DCM}$ and $\mathrm{MnO}_{2}$ (10 equiv) was added. After stirred at $23^{\circ} \mathrm{C}$ for $2 \mathrm{~h}$, the reaction mixture was filtered through Celite ${ }^{\circledR}$, concentrated in vacuo, the crude reaction mixtures were analyzed by ${ }^{1} \mathrm{H}$ NMR to determine the ratio of $21 / 21$ '. 
Table S8: Failed attempts for the diastereoselective hydrogenation of the trisubstituted double bond

\begin{tabular}{|c|c|c|c|c|c|}
\hline \multicolumn{4}{|c|}{$\begin{array}{l}14 b, R_{1}, R_{2}=O \\
14 b^{\prime}, R_{1}=O H, R_{2}=H\end{array}$} & \multicolumn{2}{|c|}{$\begin{array}{l}21, R_{1}, R_{2}=O \\
21 a, R_{1}=O H, R_{2}=H\end{array}$} \\
\hline entry & compound & catalyst & $\mathrm{H}_{2}$ & solvents & result \\
\hline 1 & $14 b$ & Raney Ni & 1 to $30 \mathrm{~atm}$ & $\mathrm{EtOH}$ & NR \\
\hline 2 & $14 b$ & Wilkinson cat. & 1 to $30 \mathrm{~atm}$ & $\mathrm{PhH}$ & NR \\
\hline 3 & $14 \mathrm{~b}$ & Crabtree cat. & $1 \mathrm{~atm}$ & DCM & decomposed \\
\hline 4 & $14 b^{\prime}$ & Raney Ni & 1 to $30 \mathrm{~atm}$ & $\mathrm{EtOH}$ & NR \\
\hline 5 & $14 b^{\prime}$ & Wilkinson cat. & 1 to $30 \mathrm{~atm}$ & $\mathrm{PhH}$ & NR \\
\hline 6 & $14 b^{\prime}$ & Crabtree cat. & $1 \mathrm{~atm}$ & DCM & decomposed \\
\hline
\end{tabular}

General procedure: To a solution of substrate in the solvent was added catalyst at $23^{\circ} \mathrm{C}$. This suspension was degassed at $-78^{\circ} \mathrm{C}$ and backfilled with $\mathrm{H}_{2}$ three times (1 atm or $30 \mathrm{~atm}$ ). After 12 $\mathrm{h}$, the reaction was concentrated in vacuo. The crude reaction mixtures were analyzed by ${ }^{1} \mathrm{H}$ NMR to determine the conversion.

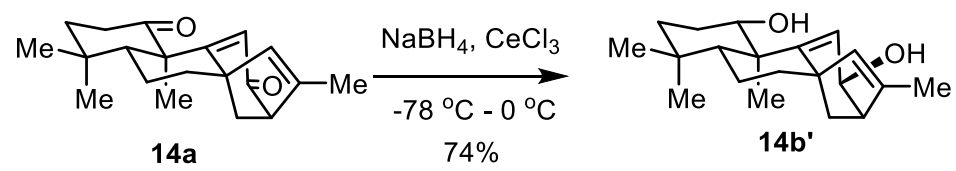

To a solution of $14 \mathrm{a}(16 \mathrm{mg}, 0.05 \mathrm{mmol})$ in $\mathrm{MeOH}(3 \mathrm{~mL})$ was added $\mathrm{NaBH}_{4}(4.2 \mathrm{mg}, 0.11 \mathrm{mmol}$, 2.0 equiv.) at $-78^{\circ} \mathrm{C}$. After stirring for $3 \mathrm{~h}$ at $-78{ }^{\circ} \mathrm{C}, \mathrm{CeCl}_{3} \cdot 7 \mathrm{H}_{2} \mathrm{O}(20.4 \mathrm{mg}, 0.055 \mathrm{mmol}, 1.1$ equiv.) was added and the reaction mixture was stirring at $0{ }^{\circ} \mathrm{C}$ for $15 \mathrm{~min}$. The excess resgents were quenched by addition of saturated aqueous $\mathrm{NaHCO}_{3}(5 \mathrm{~mL})$ and the resulting mixture was extracted with ethyl acetate $(3 \times 5 \mathrm{~mL})$. The combined organic phases were washed with brine $(5 \mathrm{~mL})$, dried over $\mathrm{Na}_{2} \mathrm{SO}_{4}$, filterred and concentrated in vacuo. The residue was purified on silica gel chromatography (Petroleum ether/acetone $=15 / 1$ to $8 / 1)$ to provide alcohol $14 b(12.0 \mathrm{mg}, 74 \%)$ as colorless oil.

Data of 14b': ${ }^{1} \mathrm{H}$ NMR (500 MHz, $\left.\mathrm{CDCl}_{3}\right) \delta 5.86(\mathrm{~s}, 1 \mathrm{H}), 5.72(\mathrm{~s}, 1 \mathrm{H}), 4.45(\mathrm{~s}, 1 \mathrm{H}), 3.76(\mathrm{dd}, \mathrm{J}=$ 15.3, $5.5 \mathrm{~Hz}, 1 \mathrm{H}), 2.80(\mathrm{t}, \mathrm{J}=5.0 \mathrm{~Hz}, 1 \mathrm{H}), 1.93-1.86(\mathrm{~m}, 1 \mathrm{H}), 1.85(\mathrm{dd}, \mathrm{J}=9.6,5.1 \mathrm{~Hz}, 1 \mathrm{H}), 1.81$ $(\mathrm{d}, \mathrm{J}=1.6 \mathrm{~Hz}, 3 \mathrm{H}), 1.69(\mathrm{dt}, \mathrm{J}=13.1,9.6 \mathrm{~Hz}, 1 \mathrm{H}), 1.64-1.58(\mathrm{~m}, 4 \mathrm{H}), 1.47-1.42(\mathrm{~m}, 1 \mathrm{H}), 1.42-1.37$ $(\mathrm{m}, 1 \mathrm{H}), 1.28-1.21(\mathrm{~m}, 3 \mathrm{H}), 1.08(\mathrm{~s}, 3 \mathrm{H}), 0.91(\mathrm{~s}, 3 \mathrm{H}), 0.86(\mathrm{~s}, 3 \mathrm{H})$;

${ }^{13} \mathrm{C} \mathrm{NMR}\left(125 \mathrm{MHz}, \mathrm{CDCl}_{3}\right) \delta 161.6,139.7,138.9,116.4,77.9,68.3,52.0,50.5,47.4,44.5,43.3$, $39.9,33.7,31.9,29.5,27.0,21.0,19.0,18.7,16.5$;

IR (film, $\mathrm{cm}^{-1}$ ) 3330, 2922, 2862, 1446, 1386, 1041, 993, 812;

HRMS(ESI) $[\mathrm{M}+\mathrm{H}]^{+}$calculated for $\mathrm{C}_{20} \mathrm{H}_{31} \mathrm{O}_{2}: 303.2139$, found: 303.2313 ;

TLC: $\mathrm{Rf}=0.45($ Petroleum ether/acetone $=4 / 1)$. 


\section{Comparison of natural and synthetic 2,22 and 24}

Table S9. Comparison of natural and synthetic ent-1a-hydroxykauran-12-one (2) ( ${ }^{1} \mathrm{H}$ NMR)

\begin{tabular}{|c|c|c|c|}
\hline & $\begin{array}{c}\text { Reported }{ }^{4} \\
{ }^{1} \mathrm{H} \mathrm{NMR}\left(400 \mathrm{MHz} \mathrm{CDCl}_{3}\right) \\
\delta[\mathrm{ppm}, \text { mult, } J(\mathrm{~Hz})]\end{array}$ & $\begin{array}{c}\text { Synthetic } \\
{ }^{1} \mathrm{H} \mathrm{NMR}\left(400 \mathrm{MHz}, \mathrm{CDCl}_{3}\right) \\
\delta[p p m, \text { mult, } J(\mathrm{~Hz})]\end{array}$ & $\begin{array}{c}\Delta \bar{\delta} \\
(\text { Synthetic-Natural) } \\
(\mathrm{ppm})\end{array}$ \\
\hline 1 & $3.26(\mathrm{dd}, 10,5)$ & $3.28(\mathrm{dd}, 10.8,4.2)$ & +0.02 \\
\hline \multirow[t]{2}{*}{2} & 1.55 & $1.56-1.54(\mathrm{~m})$ & 0 \\
\hline & 1.63 & $1.65-1.62(\mathrm{~m})$ & +0.01 \\
\hline \multirow[t]{2}{*}{3} & 1.22 & $1.30-1.27(\mathrm{~m})$ & +0.06 \\
\hline & $1.33(\mathrm{~m}, 13,4)$ & $1.36-1.34(\mathrm{~m})$ & +0.02 \\
\hline 5 & $0.71(\mathrm{dd}, 12,2)$ & $0.73(\mathrm{dd}, 11.9,1.5)$ & +0.02 \\
\hline \multirow[t]{2}{*}{6} & 1.34 & $1.39-1.37(\mathrm{~m})$ & +0.04 \\
\hline & 1.58 & $1.62-1.61(\mathrm{~m})$ & +0.03 \\
\hline 7 & 1.58 & $1.62-1.61(\mathrm{~m})$ & +0.02 \\
\hline 9 & $1.68(\mathrm{dd}, 10,2)$ & $1.69(\mathrm{~d}, 9.7 \mathrm{~Hz})$ & +0.01 \\
\hline \multirow[t]{2}{*}{11} & $2.46(\mathrm{dd}, 17,10)$ & $2.48(\mathrm{dd}, 17.1,9.5)$ & +0.02 \\
\hline & $3.65(\mathrm{dd}, 17,1)$ & $3.65(d, 17)$ & 0 \\
\hline 13 & $2.29(\mathrm{~d}, 5)$ & $2.31(\mathrm{~d}, 4.6)$ & +0.02 \\
\hline \multirow[t]{2}{*}{14} & $2.23(\mathrm{dd}, 13,2)$ & $2.25(\mathrm{~d}, 12.3)$ & +0.02 \\
\hline & $1.48(\mathrm{ddd}, 13,5,2)$ & $1.51-1.48(\mathrm{~m})$ & +0.02 \\
\hline \multirow[t]{2}{*}{15} & $1.96(\mathrm{ddd}, 13,8,1)$ & $1.99(\mathrm{dd}, 13.6,1.7)$ & +0.03 \\
\hline & $1.16(\mathrm{dd}, 13,5)$ & $1.18(\mathrm{dd}, 13.6,4.7)$ & +0.02 \\
\hline 16 & $2.12(\mathrm{~m})$ & $2.17-2.11(\mathrm{~m})$ & +0.02 \\
\hline 17 & $0.99(d, 7)$ & $1.00(\mathrm{~d}, 7.0)$ & +0.01 \\
\hline 18 & $0.83 \mathrm{~s}$ & $0.85 \mathrm{~s}$ & +0.02 \\
\hline 19 & $0.77 \mathrm{~s}$ & $0.78 \mathrm{~s}$ & +0.01 \\
\hline 20 & $0.92 \mathrm{~s}$ & $0.93 \mathrm{~s}$ & +0.01 \\
\hline
\end{tabular}


Table S10. Comparison of natural and synthetic ent-1a-hydroxykauran-12-one (2) ( $\left.{ }^{13} \mathrm{C} \mathrm{NMR}\right)$

\begin{tabular}{|c|c|c|c|}
\hline & $\begin{array}{c}\text { Reported }^{4} \\
{ }^{13} \mathrm{C} \mathrm{NMR}\left(100 \mathrm{MHz}, \mathrm{CDCl}_{3}\right) \\
\delta(\mathrm{ppm})\end{array}$ & $\begin{array}{c}\text { Synthetic } \\
{ }^{13} \mathrm{C} \mathrm{NMR}\left(100 \mathrm{MHz}, \mathrm{CDCl}_{3}\right) \\
\delta(\mathrm{ppm})\end{array}$ & $\begin{array}{c}\Delta \delta \\
\text { (Synthetic-Natural) } \\
(\mathrm{ppm})\end{array}$ \\
\hline 1 & 81.9 & 82.0 & +0.1 \\
\hline 2 & 29.8 & 29.9 & +0.1 \\
\hline 3 & 39.8 & 39.8 & 0 \\
\hline 4 & 33.2 & 33.2 & 0 \\
\hline 5 & 54.3 & 54.3 & 0 \\
\hline 6 & 20.4 & 20.5 & +0.1 \\
\hline 7 & 40.1 & 40.1 & 0 \\
\hline 8 & 46.0 & 46.0 & 0 \\
\hline 9 & 57.8 & 57.8 & 0 \\
\hline 10 & 44.6 & 44.6 & 0 \\
\hline 11 & 37.4 & 37.5 & +0.1 \\
\hline 12 & 216.9 & 216.8 & -0.1 \\
\hline 13 & 59.9 & 59.7 & -0.1 \\
\hline 14 & 36.8 & 36.8 & 0 \\
\hline 15 & 50.2 & 50.3 & +0.1 \\
\hline 16 & 35.2 & 35.2 & 0 \\
\hline 17 & 22.9 & 22.9 & 0 \\
\hline 18 & 33.0 & 33.0 & 0 \\
\hline 19 & 21.2 & 21.2 & 0 \\
\hline 20 & 12.5 & 12.6 & +0.1 \\
\hline
\end{tabular}


NMR spectra of synthetic ent-1 $\alpha$-hydroxykauran-12-one (2) ${ }^{5}$

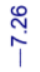

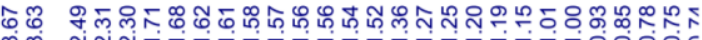
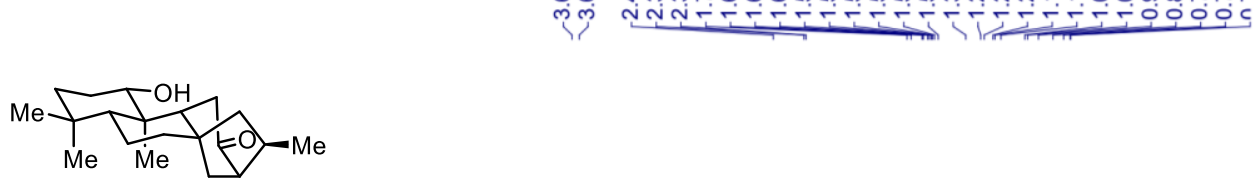

ent-1 $\alpha$-hydroxykauran-12-one (2)

${ }^{1} \mathrm{H}-\mathrm{NMR}, \mathrm{CDCl}_{3}$

$400 \mathrm{MHz}, 298 \mathrm{~K}$
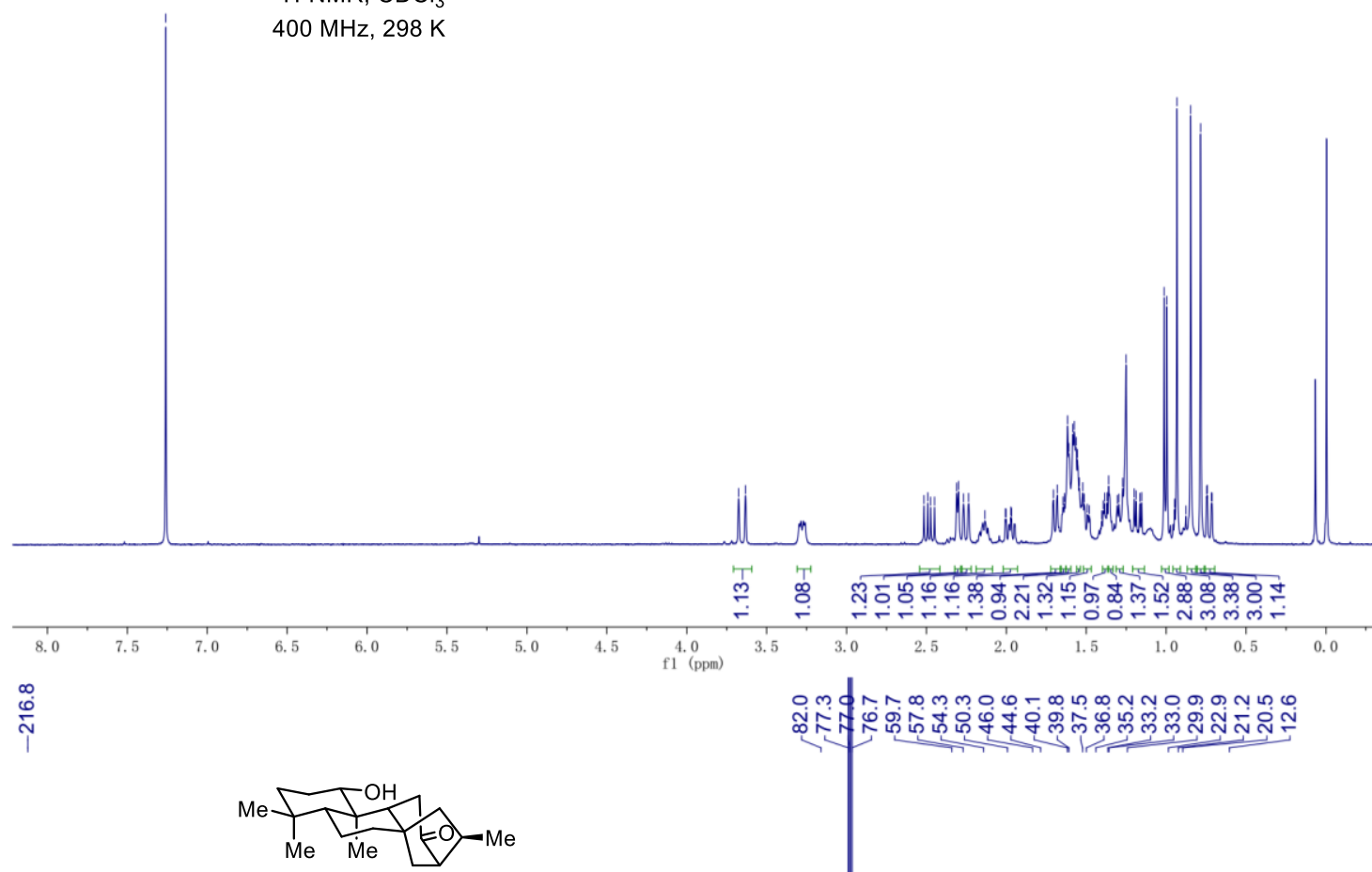

ent-1 $\alpha$-hydroxykauran-12-one (2)

${ }^{13} \mathrm{C}-\mathrm{NMR}, \mathrm{CDCl}_{3}$

$100 \mathrm{MHz}, 298 \mathrm{~K}$

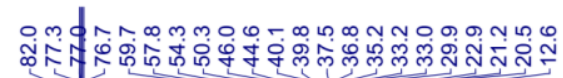

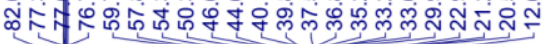


Table S11. Comparison of natural and synthetic 12-oxo-9,11-dehydrokaurene (22) ( ${ }^{1} \mathrm{H}$ NMR)

\begin{tabular}{|c|c|c|}
\hline $\begin{array}{c}\text { Natural }{ }^{6} \\
{ }^{1} \mathrm{H} \mathrm{NMR}\left(600 \mathrm{MHz} \mathrm{CDCl}_{3}\right) \\
\delta[\mathrm{ppm}, \text { mult, } J(\mathrm{~Hz})]\end{array}$ & $\begin{array}{c}\text { Synthetic } \\
{ }^{1} \mathrm{H} \text { NMR }\left(400 \mathrm{MHz}, \mathrm{CDCl}_{3}\right) \\
\delta[\mathrm{ppm}, \text { mult, } J(\mathrm{~Hz})]\end{array}$ & $\begin{array}{c}\Delta \delta \\
\text { (Synthetic-Natural) } \\
(\mathrm{ppm})\end{array}$ \\
\hline $0.88 \mathrm{~s}$ & $0.88 \mathrm{~s}$ & - \\
\hline $0.97 \mathrm{~s}$ & $0.96 \mathrm{~s}$ & -0.01 \\
\hline $1.18 \mathrm{~s}$ & $1.17 \mathrm{~s}$ & -0.01 \\
\hline $3.38 \mathrm{br} \mathrm{s}$ & $3.37 \mathrm{~d}(4.6)$ & -0.01 \\
\hline 4.98 br s & $4.97 \mathrm{br} \mathrm{s}$ & -0.01 \\
\hline $5.24 \mathrm{br} \mathrm{s}$ & $5.24 \mathrm{br} \mathrm{s}$ & - \\
\hline $5.71 \mathrm{br} \mathrm{s}$ & $5.70 \mathrm{br} \mathrm{s}$ & -0.01 \\
\hline
\end{tabular}


NMR spectra of synthetic 12-oxo-9,11-dehydrokaurene $(22)^{7}$
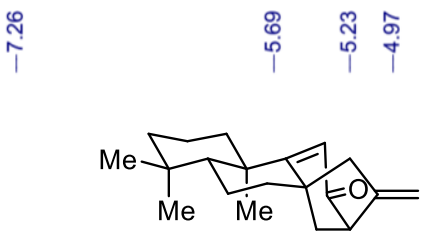

12-oxo-9,11-dehydrokaurene (22)

${ }^{1} \mathrm{H}-\mathrm{NMR}, \mathrm{CDCl}_{3}$

$400 \mathrm{MHz}, 298 \mathrm{~K}$
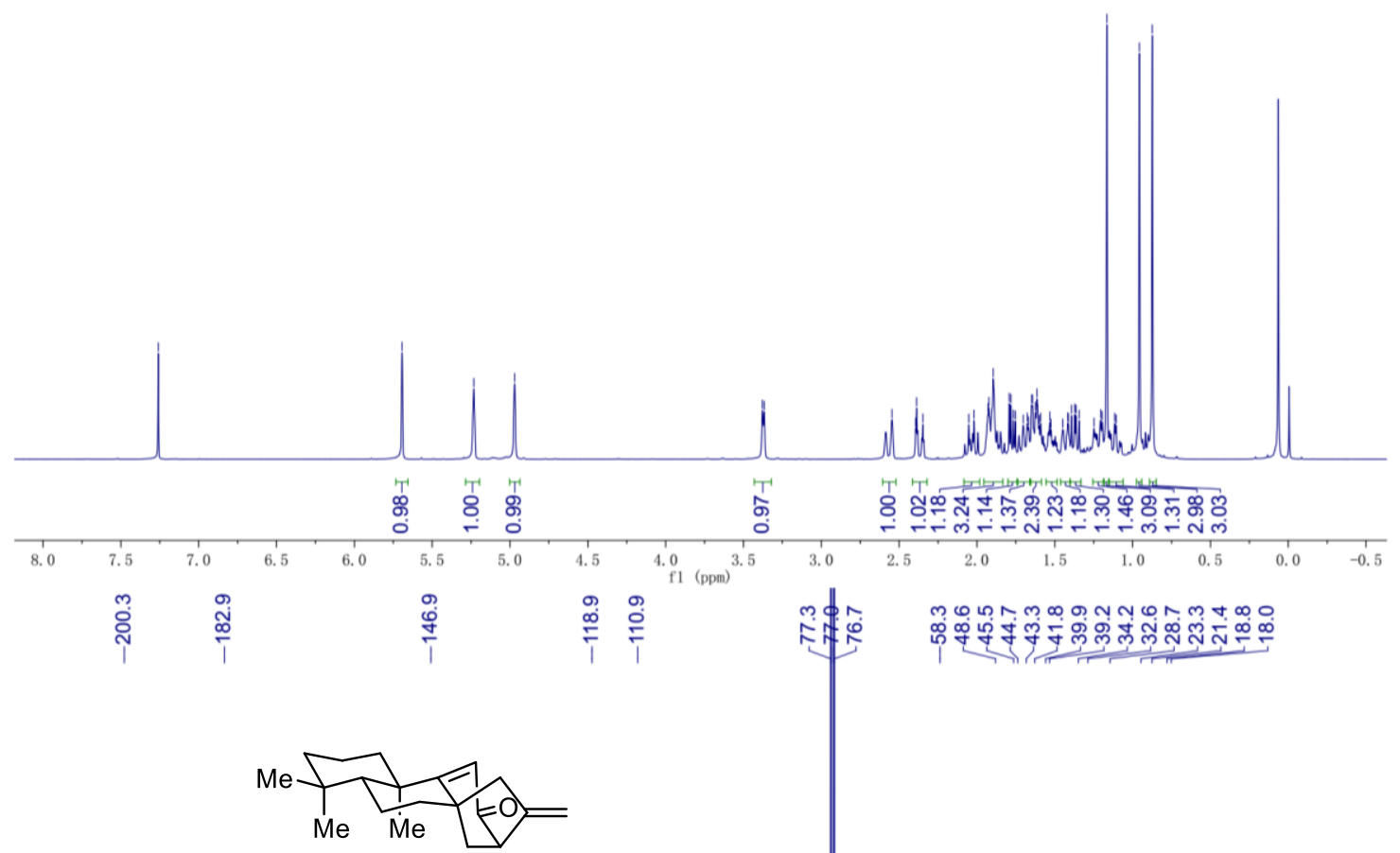

12-oxo-9,11-dehydrokaurene (22)

${ }^{13} \mathrm{C}-\mathrm{NMR}, \mathrm{CDCl}_{3}$

$100 \mathrm{MHz}, 298 \mathrm{~K}$

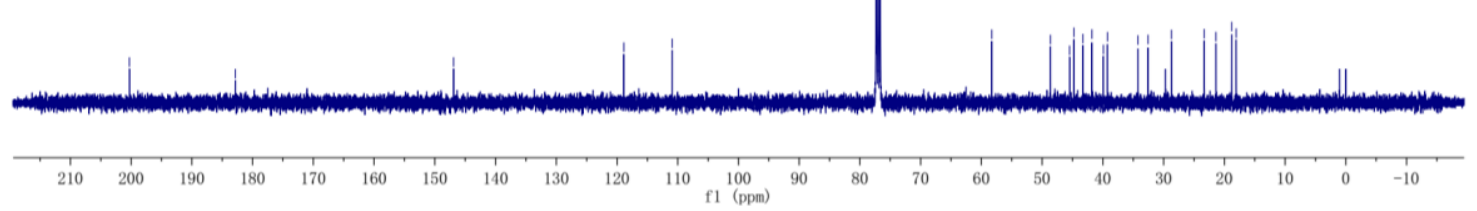


Table S12. Comparison of natural and synthetic 12a-hydroxy-9,11-dehydrokaurene (24) ( ${ }^{1} \mathrm{H}$ NMR)

\begin{tabular}{|c|c|c|}
\hline $\begin{array}{c}\text { Natural }^{6} \\
{ }^{1} \mathrm{H} \mathrm{NMR}\left(600 \mathrm{MHz}^{\left.-\mathrm{CDCl}_{3}\right)}\right. \\
\delta[\mathrm{ppm}, \text { mult, } J(\mathrm{~Hz})]\end{array}$ & $\begin{array}{c}\text { Synthetic } \\
{ }^{1} \mathrm{H} \text { NMR }\left(400 \mathrm{MHz}, \mathrm{CDCl}_{3}\right) \\
\delta[\mathrm{ppm}, \text { mult, } J(\mathrm{~Hz})]\end{array}$ & $\begin{array}{c}\Delta \delta \\
\text { (Synthetic-Natural) } \\
(\mathrm{ppm})\end{array}$ \\
\hline $0.84 \mathrm{~s}$ & $0.84 \mathrm{~s}$ & - \\
\hline $0.92 \mathrm{~s}$ & $0.92 \mathrm{~s}$ & 0 \\
\hline $1.10 \mathrm{~s}$ & $1.10 \mathrm{~s}$ & 0 \\
\hline $1.82 \mathrm{br} \mathrm{s}^{8}$ & - & - \\
\hline $2.85 \mathrm{br} \mathrm{s}$ & $2.85 \mathrm{br} \mathrm{s}$ & 0 \\
\hline $3.95 \mathrm{dd}(4.0,3.5)$ & $3.94 \mathrm{t}(3.4)$ & -0.01 \\
\hline $4.90 \mathrm{br} \mathrm{s}$ & $4.90 \mathrm{br} \mathrm{s}$ & 0 \\
\hline $5.05 \mathrm{br} \mathrm{s}$ & $5.04 \mathrm{br} \mathrm{s}$ & -0.01 \\
\hline $5.30 \mathrm{br} \mathrm{s}$ & $5.29 \mathrm{~d}(3.9)$ & -0.01 \\
\hline
\end{tabular}


NMR spectra of synthetic 12a-hydroxy-9,11-dehydrokaurene (24) ${ }^{9}$
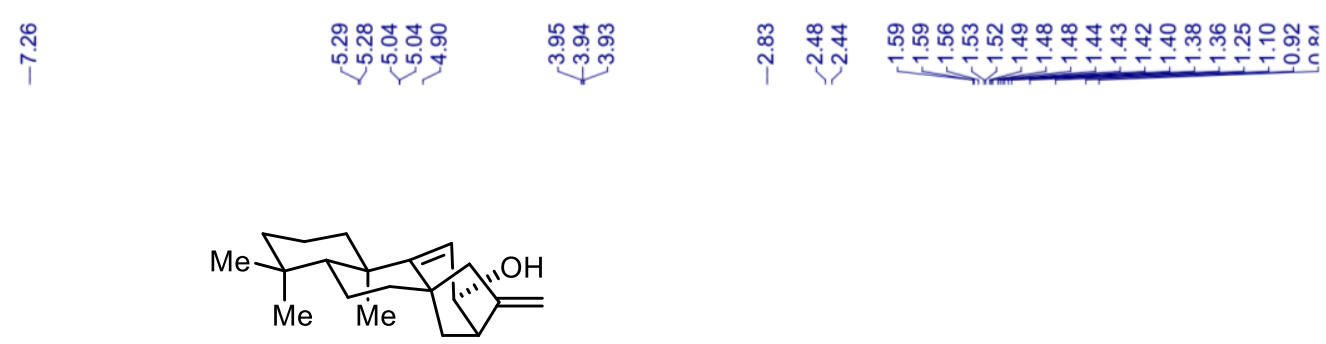

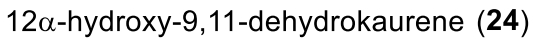

${ }^{1} \mathrm{H}-\mathrm{NMR}, \mathrm{CDCl}_{3}$ $400 \mathrm{MHz}, 298 \mathrm{~K}$
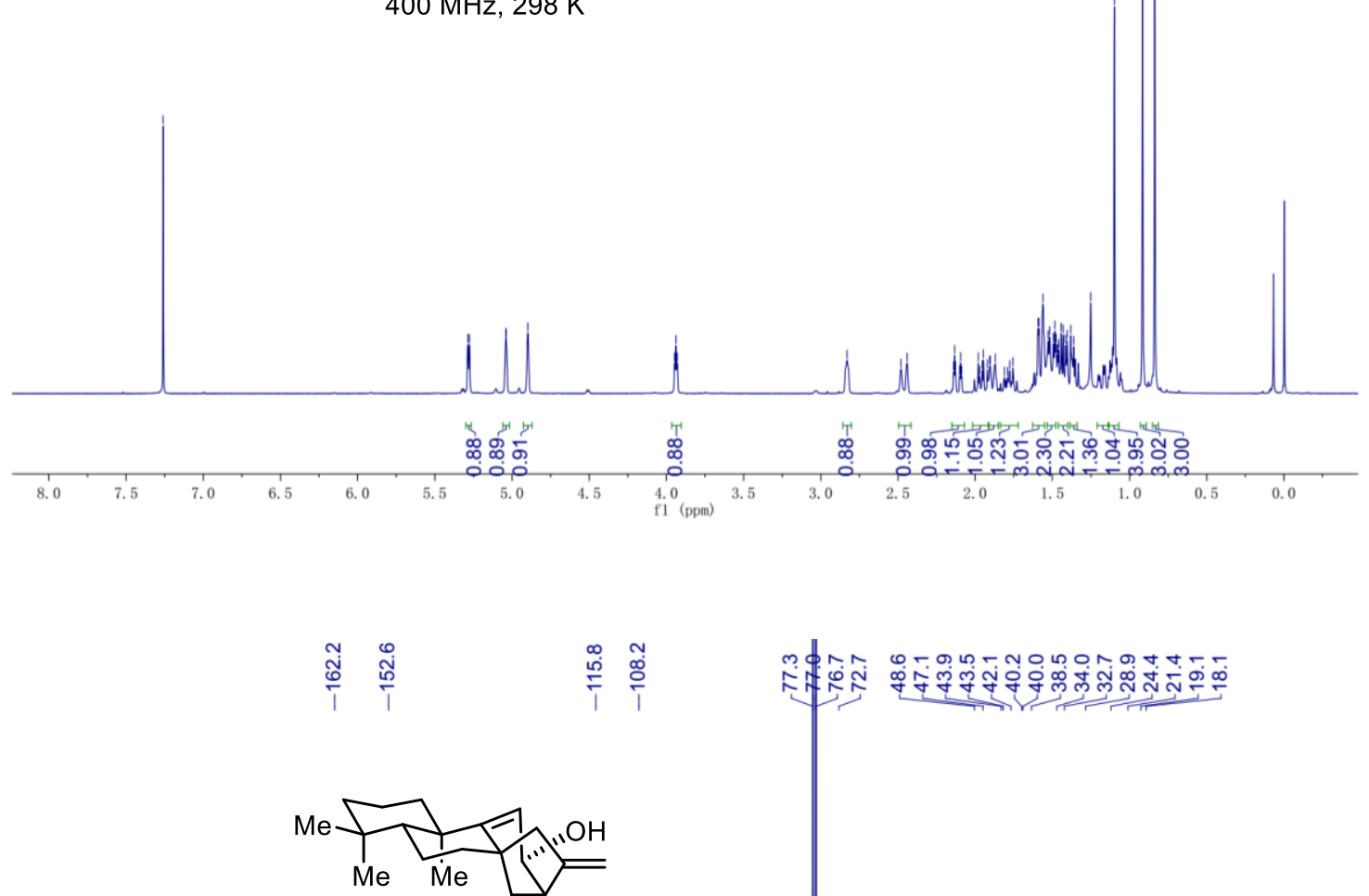

12 $\alpha$-hydroxy-9,11-dehydrokaurene(24)

${ }^{13} \mathrm{C}-\mathrm{NMR}, \mathrm{CDCl}_{3}$

$100 \mathrm{MHz}, 298 \mathrm{~K}$

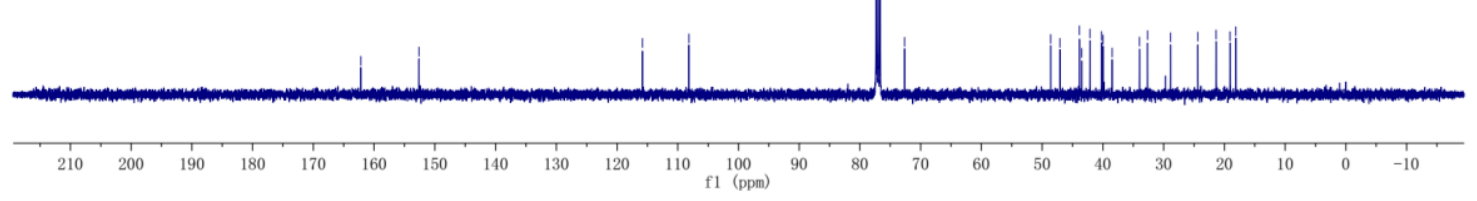




\section{Substrate synthesis for the Rh-catalyzed $[3+2+1]$ cycloaddition}

\subsection{Synthesis of $8 a \& 8 b \& 8 c$}

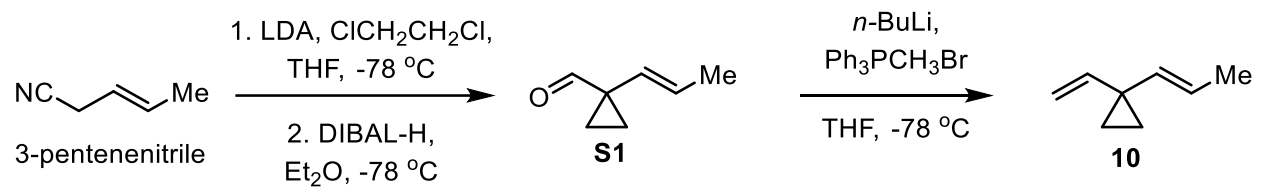

Aldehyde S1 (45.5 g, $412.7 \mathrm{mmol}$ ) was prepared from 3-pentenenitrile $(50 \mathrm{~g}, 616 \mathrm{mmol})$ in 2 steps as literature reported without futher purification. ${ }^{10}$

To a solution of $\mathrm{Ph}_{3} \mathrm{PCH}_{3} \mathrm{Br}\left(194 \mathrm{~g}, 544 \mathrm{mmol}, 1.3\right.$ equiv.) in THF $(800 \mathrm{~mL})$ at $0{ }^{\circ} \mathrm{C}$ was added $n$ BuLi (2.4 M in hexane, $190 \mathrm{~mL}, 454 \mathrm{mmol}, 1.3$ equiv.) dropwise over 30 minutes. After stirring at this temperature for 30 minutes, aldehyde $\mathbf{S 1}$ (crude from last two steps, 1.0 equiv.) was added dropwise over 30 minutes. After $1 \mathrm{~h}$ the reaction was warmed to $23^{\circ} \mathrm{C}$ and the excess reagents were quenched with saturated aq. $\mathrm{NH}_{4} \mathrm{Cl}(400 \mathrm{~mL})$ and the resulting mixture was extracted with $\mathrm{Et}_{2} \mathrm{O}(3 \times 300 \mathrm{~mL})$. The organic layers were combined, washed with $\mathrm{H}_{2} \mathrm{O}(500 \mathrm{~mL})$, brine $(500 \mathrm{~mL})$, dried $\left(\mathrm{Na}_{2} \mathrm{SO} 4\right)$, filtered and concentrated in vacuo (below $20^{\circ} \mathrm{C}$ ) to afford a crude oil. The crude oil thus obtained was distilled at aspirator vacuum to give a solution of 10 (2.92 M in THF, $54 \mathrm{~mL}$, $26 \%$ for three step).

Data of 10: $\left(400 \mathrm{MHz}, \mathrm{CDCl}_{3}\right) \delta 5.66(\mathrm{dd}, J=17.2,10.4 \mathrm{~Hz}, 1 \mathrm{H}), 5.47(\mathrm{dd}, J=15.3,1.3 \mathrm{~Hz}, 1 \mathrm{H})$, $5.36(\mathrm{dt}, J=9.0,6.2 \mathrm{~Hz}, 1 \mathrm{H}), 4.94-4.77(\mathrm{~m}, 2 \mathrm{H}), 1.61(\mathrm{dd}, J=6.2,1.3 \mathrm{~Hz}, 3 \mathrm{H}), 0.69(\mathrm{dt}, J=10.4$, $2.4 \mathrm{~Hz}, 4 \mathrm{H})$;

${ }^{13} \mathrm{C}$ NMR $\left(100 \mathrm{MHz}, \mathrm{CDCl}_{3}\right) \delta 142.9,133.7,123.8,111.6,67.9,25.6,14.7$;

HRMS(EI) [M] + calculated for $\mathrm{C}_{8} \mathrm{H}_{12}: 108.0934$, found: 108.0935;

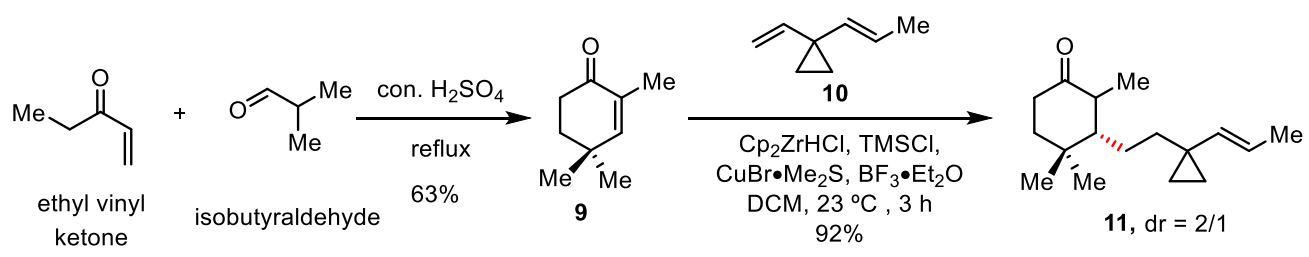

Enone 9 is commercially available or can be prepared from ethyl vinyl ketone and isobutyraldehyde in 1 step as literature reported. ${ }^{11}$ To a stirred solution of alkene 10 (31 mL in THF, $2.92 \mathrm{mM}, 90.4$ mmol, 4.0 equiv.) in $50 \mathrm{~mL}$ dry dichloromethane was added $\mathrm{Cp}_{2} \mathrm{ZrHCl}$ (18.6 g, $72.3 \mathrm{mmol}, 3.2$ equiv.) at $23{ }^{\circ} \mathrm{C}$ and stirred for $20 \mathrm{~min}$, then $\mathrm{CuBr} \cdot \mathrm{Me}_{2} \mathrm{~S}$ ( $4.65 \mathrm{~g}, 22.6 \mathrm{mmol}, 1.0$ equiv.) was added and stirred for additional $40 \mathrm{~min}$. Then enone 9 ( $3.4 \mathrm{~mL}, 22.6 \mathrm{mmol}, 1.0$ equiv.) was added dropwise. 5 min later, chlorotrimethylsilane $\left(9.8 \mathrm{~mL}, 113.4 \mathrm{mmol}, 5.0\right.$ equiv.) and $\mathrm{BF}_{3} \cdot \mathrm{Et}_{2} \mathrm{O}(2.8 \mathrm{~mL}, 22.6 \mathrm{mmol}$, 1.0 equiv.) was added. After $4 \mathrm{~h}$, the excess reagents were quenched by saturated aqueous $\mathrm{NH}_{4} \mathrm{Cl}$ solution $(250 \mathrm{~mL})$, the resulting mixture was extracted with dichloromethane (200 $\mathrm{mL} \times 3)$, washed 
with brine $(200 \mathrm{~mL})$, the combined organic phases were dried over anhydrous $\mathrm{Na}_{2} \mathrm{SO}_{4}$, concentrated in vacuo to afford a crude oil, which was purified by flash chromatography (Petroleum ether/Ethyl acetate $=10 / 1)$ to afford 11 as a yellow oil $(5.16 \mathrm{~g}, 92 \%)$.

Data of 11: ${ }^{1} \mathrm{H}$ NMR (400 MHz, $\left.\mathrm{CDCl}_{3}\right)$ ס 5.41-5.16 (m, 2H), 2.87-2.77 (m, 0.2H), 2.52-2.40 (m, $0.7 \mathrm{H}), 2.40-2.31(\mathrm{~m}, 0.3 \mathrm{H}), 2.30-2.20(\mathrm{~m}, 1.7 \mathrm{H}), 1.86-1.76(\mathrm{~m}, 0.4 \mathrm{H}), 1.73-1.69(\mathrm{~m}, 0.3 \mathrm{H}), 1.68-$ $1.62(\mathrm{~m}, 3 \mathrm{H}), 1.62-1.54(\mathrm{~m}, 3 \mathrm{H}), 1.54-1.45(\mathrm{~m}, 1.4 \mathrm{H}), 1.39-1.34(\mathrm{~m},, 0.5 \mathrm{H}), 1.33-1.25(\mathrm{~m}, 1.6 \mathrm{H})$, 1.07-0.92 (m, 9H), 0.52-0.40 (m, 2H);

${ }^{13} \mathrm{C} \mathrm{NMR}\left(100 \mathrm{MHz}, \mathrm{CDCl}_{3}\right) \delta$ 214.3, 213.6, 135.8, 135.7, 122.0, 121.9, 54.2, 53.4, 47.3, 45.0, 41.4, $39.5,39.0,38.2,37.8,36.2,34.5,29.4,28.4,27.7,27.4,23.8,22.2,22.1,19.6,17.9,13.7,13.6$, 13.6, 12.7, 12.5;

IR (film, cm-1) 2961, 2870, 1710, 1451,1368, 1012, 964;

HRMS(ESI) $\left[\mathrm{M}+\mathrm{H}^{+}\right.$calculated for $\mathrm{C}_{17} \mathrm{H}_{29} \mathrm{O}: 249.2213$, found: 249.2212;

TLC: $\mathrm{Rf}=0.68($ Petroleum ether/Ethyl acetate $=10 / 1)$.
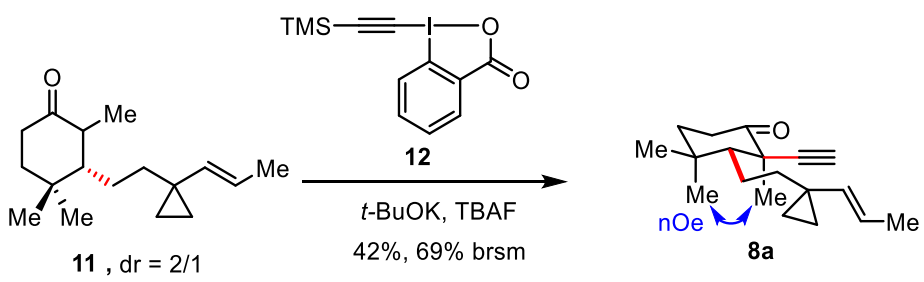

To a solution of 11 (1.04 g, $4.19 \mathrm{mmol}, 1.0$ equiv.) in THF $(40 \mathrm{~mL})$ was added a solution of $t$-BuOK (1 $\mathrm{M}$ in THF, $5.4 \mathrm{~mL}, 5.4 \mathrm{mmol}, 1.28$ equiv.) at $23^{\circ} \mathrm{C}$. After $1 \mathrm{~h}$, the solution was cooled to $-78{ }^{\circ} \mathrm{C}$, TMS-EBX 12 (2.88 g, 8.37 mmol, 2.0 equiv.) and TBAF (1 M in THF, $8.37 \mathrm{~mL}, 8.37 \mathrm{mmol}, 2.0$ equiv.) were added sequentially. The reaction mixture was stirred for another $2.5 \mathrm{~h}$ then the excess reagents were quenched by saturated aqueous $\mathrm{NH}_{4} \mathrm{Cl}$ solution $(50 \mathrm{~L})$, the resulting mixture was extracted with ethyl acetate $(50 \mathrm{~mL} \times 3)$, washed with brine $(50 \mathrm{~mL})$, the combined organic phases were dried over anhydrous $\mathrm{Na}_{2} \mathrm{SO}_{4}$, concentrated in vacuo to afford a crude oil, which was purified by flash chromatography (Petroleum ether/Ethyl acetate $=200 / 1$ ) to afford 8 a as a yellow oil (479 $\mathrm{mg}, 42 \%$ ) and recover 11 (406 mg, 39\%).

Data of 8a: ${ }^{1} \mathrm{H}$ NMR $\left(400 \mathrm{MHz}, \mathrm{CDCl}_{3}\right) \delta 5.45-5.35(\mathrm{~m}, 1 \mathrm{H}), 5.22(\mathrm{dd}, J=15.4,1.5 \mathrm{~Hz}, 1 \mathrm{H}), 2.63$ (ddd, $J=14.8,12.4,6.1 \mathrm{~Hz}, 1 \mathrm{H}), 2.41(\mathrm{dt}, J=14.8,4.6 \mathrm{~Hz}, 1 \mathrm{H}), 2.33(\mathrm{~s}, 1 \mathrm{H}), 1.73-1.67(\mathrm{~m}, 1 \mathrm{H})$, $1.66(\mathrm{dd}, J=6.4,1.5 \mathrm{~Hz}, 3 \mathrm{H}), 1.61-1.56(\mathrm{~m}, 2 \mathrm{H}), 1.55-1.45(\mathrm{~m}, 2 \mathrm{H}), 1.56-1.44(\mathrm{~m}, 2 \mathrm{H}), 1.42(\mathrm{~s}$, $3 \mathrm{H}), 1.04(\mathrm{~s}, 3 \mathrm{H}), 1.02(\mathrm{~s}, 3 \mathrm{H}), 0.52-0.43(\mathrm{~m}, 4 \mathrm{H})$;

${ }^{13} \mathrm{C}$ NMR $\left(100 \mathrm{MHz}, \mathrm{CDCl}_{3}\right) \delta$ 209.6, 135.9, 121.7, 87.2, 72.0, 54.8, 50.6, 39.8, 39.8, 34.4, 34.3, $31.9,25.5,22.3,22.0,21.5,17.9,14.0,13.7$;

IR (film, cm-1) 3308, 2926, 1719, 1455, 1013, 1967, 635;

HRMS(ESI) $[\mathrm{M}+\mathrm{H}]^{+}$calculated for $\mathrm{C}_{19} \mathrm{H}_{29} \mathrm{O}: 273.2213$, found: 273.2215 ;

TLC: $\mathrm{Rf}=0.5($ Petroleum ether/Ethyl acetate $=10 / 1)$. 


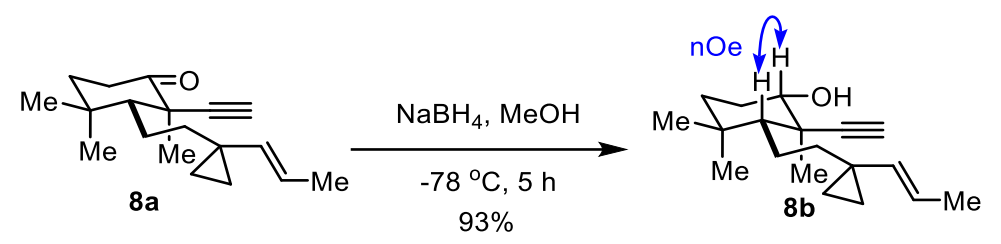

To a solution of ketone $8 \mathrm{a}$ (30 mg, $0.11 \mathrm{mmol}, 1.0$ equiv.) in $\mathrm{MeOH}(15 \mathrm{~mL})$ was added $\mathrm{NaBH}_{4}(8.4$ $\mathrm{mg}, 0.22 \mathrm{mmol}, 2.0$ equiv.) at $-78{ }^{\circ} \mathrm{C}$. After stirring at $-78{ }^{\circ} \mathrm{C}$ for $5 \mathrm{~h}$, the excess reagents were quenched by addition of saturated aqueous $\mathrm{NH}_{4} \mathrm{Cl}(10 \mathrm{~mL})$ and the resulting mixture was extracted with ethyl acetate $(3 \times 15 \mathrm{~mL})$. The combined organic phases were washed with brine $(15 \mathrm{~mL})$, dried over $\mathrm{Na}_{2} \mathrm{SO}_{4}$, filterred and concentrated in vacuo. The residue was purified on silica gel chromatography (Petroleum ether/Ethyl acetate $=20 / 1$ ) to provide alcohol $\mathbf{8 b}$ as colorless oil $(28$ mg, 93\%).

Data of alcohol 8b: ${ }^{1} \mathrm{H}$ NMR $\left(500 \mathrm{MHz}, \mathrm{CDCl}_{3}\right) \delta 5.43$ (dq, $\left.J=15.4,6.4 \mathrm{~Hz}, 1 \mathrm{H}\right), 5.24(\mathrm{dd}, J=$ 15.5, $1.4 \mathrm{~Hz}, 1 \mathrm{H}$ ), 3.60 (ddd, $J=11.7,3.9,2.2 \mathrm{~Hz}, 1 \mathrm{H}), 2.14(\mathrm{~s}, 1 \mathrm{H}), 2.08(\mathrm{~d}, J=2.4 \mathrm{~Hz}, 1 \mathrm{H})$, 1.70-1.64 (m, 5H), 1.63-1.57 (m, 1H), 1.55-1.52 (m, 1H), 1.51-1.40 (m, 3H), $1.29(\mathrm{dd}, J=13.6$, $3.9 \mathrm{~Hz}, 1 \mathrm{H}), 1.17(\mathrm{~s}, 3 \mathrm{H}), 1.14(\mathrm{t}, J=3.6 \mathrm{~Hz}, 1 \mathrm{H}), 0.88(\mathrm{~s}, 3 \mathrm{H}), 0.85(\mathrm{~s}, 3 \mathrm{H}), 0.55-0.45(\mathrm{~m}, 4 \mathrm{H})$; ${ }^{13} \mathrm{C}$ NMR $\left(126 \mathrm{MHz}, \mathrm{CDCl}_{3}\right) \delta 136.2,121.5,92.2,77.8,68.9,52.7,43.3,40.5,39.4,34.4,32.8$, 25.7, 25.1, 22.3, 22.0, 17.9, 15.3, 14.1, 13.8;

IR (film, cm-1) 3305, 3073, 2990, 2941, 2860, 1459, 1388, 1074, 1035, 1016, 964; HRMS(ESI) $[\mathrm{M}+\mathrm{H}]^{+}$calculated for $\mathrm{C}_{19} \mathrm{H}_{31} \mathrm{O}: 275.2369$, found: 275.2366 ;

TLC: $\mathrm{Rf}=0.43$ (Petroleum ether/Ethyl acetate $=10 / 1)$.

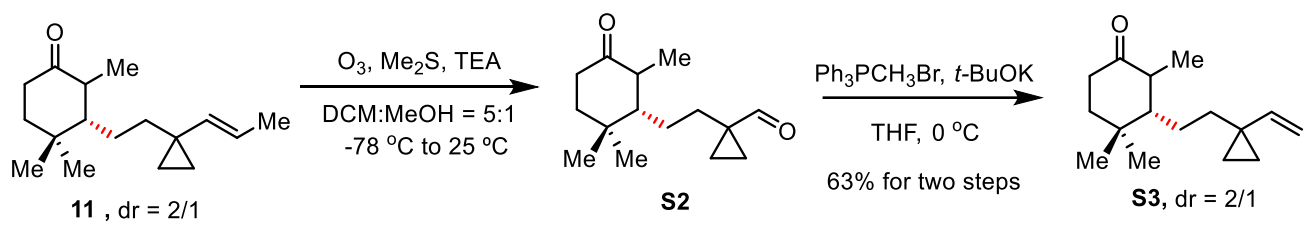

Ozone was bubbled through a solution of compound 11 (150 mg, $0.60 \mathrm{mmol}, 1.0$ equiv.) in $15 \mathrm{~mL}$ $\mathrm{DCM} / \mathrm{MeOH}(\mathrm{v}: \mathrm{v}=5: 1)$ at $-78{ }^{\circ} \mathrm{C}$ until a pale blue color persisted. The mixture was purged with argon to remove excess ozone before $\mathrm{Me}_{2} \mathrm{~S}$ (446 uL, $6.03 \mathrm{mmol}, 10.0$ equiv.) and $\mathrm{Et}_{3} \mathrm{~N}$ (840 uL, 6.03 mmol, 10.0 equiv.) were introduced. After stirring for $10 \mathrm{~min}$ at $-78{ }^{\circ} \mathrm{C}$, the mixture was allowed to reach ambient temperature. After stirring for $30 \mathrm{~min}$, the mixture was concentrated in vacuo to afford a crude oil. The crude residue $\mathbf{S} 2$ was directed used in the next step.

To a solution of $\mathrm{Ph}_{3} \mathrm{PCH}_{3} \mathrm{Br}$ (232 mg, $0.65 \mathrm{mmol}, 1.08$ equiv.) in THF (20 mL) was added $t$-BuOK (1 $\mathrm{M}$ in THF, $650 \mathrm{uL}, 0.65 \mathrm{mmol}, 1.08$ equiv.) at $0{ }^{\circ} \mathrm{C}$ dropwise. The reaction was stirred at $0{ }^{\circ} \mathrm{C}$ for $15 \mathrm{~min}$ and warmed to $23^{\circ} \mathrm{C}$ for $45 \mathrm{~min}$ then cooled to $0^{\circ} \mathrm{C}$. A solution of $\mathbf{S} 2$ in THF $(2 \mathrm{~mL})$ was added to the mixture dropwise at $0{ }^{\circ} \mathrm{C}$, and the reaction mixture was stirred at $0{ }^{\circ} \mathrm{C}$ for $1 \mathrm{~h}$. After the reaction was completed, the excess reagents were quenched by saturated aqueous $\mathrm{NH}_{4} \mathrm{Cl}$ 
solution $(20 \mathrm{~mL})$, the resulting mixture was extracted with ethyl acetate $(20 \mathrm{~mL} \times 3)$, washed with brine $(50 \mathrm{~mL})$, the combined organic phases were dried over anhydrous $\mathrm{Na}_{2} \mathrm{SO}_{4}$, concentrated in vacuo to afford a crude oil, which was purified by flash chromatography (Petroleum ether/Ethyl acetate $=30 / 1$ ) to afford $\mathbf{S 3}$ as a white solid ( $89 \mathrm{mg}, 63 \%$ for two steps).

Data of alcohol S3: ${ }^{1} \mathrm{H}$ NMR $\left(400 \mathrm{MHz}, \mathrm{CDCl}_{3}\right) \delta$ 5.66-5.51 (m, 1H), 4.96-4.86 (m, 2H), 2.53$2.40(\mathrm{~m}, 1 \mathrm{H}), 2.33-2.21(\mathrm{~m}, 2 \mathrm{H}), 1.86-1.47(\mathrm{~m}, 4 \mathrm{H}), 1.40-1.20(\mathrm{~m}, 3 \mathrm{H}), 1.07-0.95(\mathrm{~m}, 9 \mathrm{H}), 0.63$ $-0.48(\mathrm{~m}, 4 \mathrm{H})$;

${ }^{13} \mathrm{C}$ NMR $\left(100 \mathrm{MHz}, \mathrm{CDCl}_{3}\right) \delta 213.5,143.5,110.8,54.1,47.2,41.3,38.2,38.0,34.5,29.3,28.3$, 23.1, 19.6, 14.1, 14.1, 12.7;

IR (film, cm-1) 2965, 2870, 1710, 1450, 1426, 1152, 1012, 992, 894;

HRMS(ESI) $[\mathrm{M}+\mathrm{H}]^{+}$calculated for $\mathrm{C}_{16} \mathrm{H}_{27} \mathrm{O}: 235.2056$, found: 235.2052;

TLC: $\mathrm{Rf}=0.60($ Petroleum ether/Ethyl acetate $=10 / 1)$.

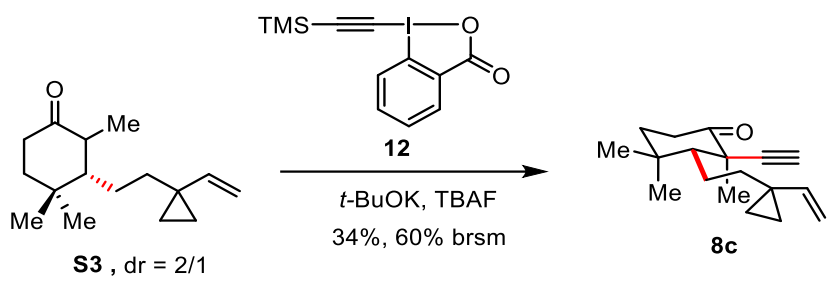

To a solution of $\mathbf{S} 3$ ( $89 \mathrm{mg}, 0.38 \mathrm{mmol}, 1.0$ equiv.) in THF (3 mL) was added a solution of $t$-BuOK (1 $\mathrm{M}$ in THF, $380 \mathrm{uL}, 0.38 \mathrm{mmol}, 1.0$ equiv.) at $23^{\circ} \mathrm{C}$. After $1 \mathrm{~h}$, the solution was cooled to $-78{ }^{\circ} \mathrm{C}$, TMS-EBX 12 (262 mg, 0.76 mmol, 2.0 equiv.) and TBAF (1 M in THF, $760 \mathrm{uL}, 0.76 \mathrm{mmol}, 2.0$ equiv.) were added sequentially. The reaction mixture was stirred for $2 \mathrm{~h}$ then the excess reagents were quenched by saturated aqueous $\mathrm{NH}_{4} \mathrm{Cl}$ solution $(5 \mathrm{~mL})$, the resulting mixture was extracted with ethyl acetate $(10 \mathrm{~mL} \times 3)$, washed with brine $(10 \mathrm{~mL})$, the combined organic phases were dried over anhydrous $\mathrm{Na}_{2} \mathrm{SO}_{4}$, concentrated in vacuo to afford a crude oil, which was purified by flash chromatography (Petroleum ether/Ethyl acetate $=40 / 1$ ) to afford $8 \mathrm{c}$ as a white solid (33 $\mathrm{mg}, 34 \%$ ) and recover $\mathbf{S 3} 35 \mathrm{mg}$ (39\%).

Data of 8c: ${ }^{1} \mathrm{H}$ NMR $\left(400 \mathrm{MHz}, \mathrm{CDCl}_{3}\right) \delta 5.56(\mathrm{dd}, J=17.4,10.6 \mathrm{~Hz}, 1 \mathrm{H}), 4.96(\mathrm{ddd}, J=14.0$, 11.9, 1.2 Hz, 2H), 2.66 (ddd, J = 14.8, 12.7, $6.1 \mathrm{~Hz}, 1 \mathrm{H}), 2.41$ (dt, $J=14.8,4.5 \mathrm{~Hz}, 1 \mathrm{H}), 2.35$ $(\mathrm{s}, 1 \mathrm{H}), 1.76-1.60(\mathrm{~m}, 5 \mathrm{H}), 1.57-1.47(\mathrm{~m}, 2 \mathrm{H}), 1.43(\mathrm{~s}, 3 \mathrm{H}), 1.04(\mathrm{~d}, J=12.1 \mathrm{~Hz}, 6 \mathrm{H}), 0.61-$ $0.49(\mathrm{~m}, 4 \mathrm{H})$;

${ }^{13} \mathrm{C}$ NMR $\left(126 \mathrm{MHz}, \mathrm{CDCl}_{3}\right)$ ठ 209.6, 143.6, 110.8, 100.0, 87.1, 72.1, 54.8, 50.6, 39.8, 38.9, 34.4, $34.3,31.9,25.5,23.2,21.9,21.5,14.5,14.3$;

IR (film, cm-1) 2957, 2888, 1718, 1636, 1456, 1427, 1392, 1142, 1013, 897;

HRMS(ESI) $[\mathrm{M}+\mathrm{H}]^{+}$calculated for $\mathrm{C}_{18} \mathrm{H}_{27} \mathrm{O}: 259.2056$, found: 259.2055 ;

TLC: $\mathrm{Rf}=0.50($ Petroleum ether/Ethyl acetate $=10 / 1)$. 


\subsection{Synthesis of $8 e$}

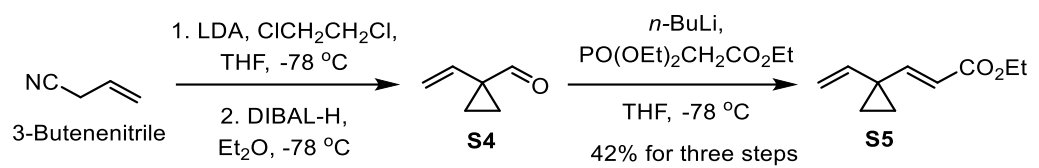

A dry $2 \mathrm{~L}$ flask equipped with a mechanical stirrer and addition funnel was charged with dry THF $(750 \mathrm{~mL})$ and diisopropylamine $(115 \mathrm{~mL}, 820 \mathrm{mmol}, 2.75$ equiv.). The mixture was cooled in a dry ice-acetone bath to an internal temperature of $-60^{\circ} \mathrm{C}$. A $2.4 \mathrm{M}$ solution of $n$-butyllithium $(310 \mathrm{~mL}$, $745 \mathrm{mmol}, 2.5$ equiv.) in hexane was then added dropwise over $30 \mathrm{~min}$. After the addition was completed, the solution was stirred for an additional $20 \mathrm{~min}$, then DMPU (22 mL) was added. A solution of 3-butenenitirile ( $24 \mathrm{~mL}, 298 \mathrm{mmol}, 1.0$ equiv.) in THF (26 mL) was then added dropwise over $30 \mathrm{~min}$. After another $30 \mathrm{~min}$, the mixture was allowed to warm gradually to $-30{ }^{\circ} \mathrm{C}$ over 45 $\min$. The orange homogenous solution was subsequently cooled to $-65^{\circ} \mathrm{C}$, and 1,2 -dichloroethane (118 mL, $1.49 \mathrm{~mol}, 5.0$ equiv.) was then added dropwise over 20 mins. The solution was then allowed to warm to $-10^{\circ} \mathrm{C}$ for $0.5-1 \mathrm{~h}$ at which time the reaction was monitored to be completed by $\mathrm{GC}$ analysis of an aliquot of reaction mixture. The excess reagents were quenched by the addition of saturated $\mathrm{NH}_{4} \mathrm{Cl}(150 \mathrm{~mL})$ solution. The mixture was diluted with $\mathrm{Et}_{2} \mathrm{O}(800 \mathrm{~mL})$, and the organic phase was extracted with $\mathrm{Et}_{2} \mathrm{O}$, washed with dilute $\mathrm{HCl}$ until the washings were acidic, followed by water, saturated $\mathrm{NaHCO}_{3}$, and brine. The organic phase was dried over $\mathrm{Na}_{2} \mathrm{SO}_{4}$, filtered and concentrated in vacuo (below $23^{\circ} \mathrm{C}$ ) to afford a crude oil, which was used for the next step without further purification.

A dry $2 \mathrm{~L}$ flask under Ar was charged with ether $(600 \mathrm{~mL})$ and the crude product from last step. This solution was cooled to ${ }^{\circ} \mathrm{C}$ and a solution of $1.0 \mathrm{M}$ DIBAL-H in hexane $(330 \mathrm{~mL}, 330 \mathrm{mmol}, 1.1$ equiv.) was added dropwise over $30 \mathrm{~min}$. The mixture was kept at $0{ }^{\circ} \mathrm{C}$ for $3 \mathrm{~h}$, then cannulated in a slow stream into a vigorously stirred suspension of $10 \%$ sulfuric acid $(650 \mathrm{~mL})$ in ether $(500 \mathrm{~mL})$ cooled in a large ice bath. The resulting yellow solution was stirred for $30 \mathrm{~min}$ at $0{ }^{\circ} \mathrm{C}$, and the layers were then separated. The aqueous layer was extracted with ether $(300 \mathrm{~mL})$, the ether extracts were combined and washed with water, saturated $\mathrm{NaHCO}_{3}$, and brine. After dried over $\mathrm{Na}_{2} \mathrm{SO}_{4}$, the mixture was filtered and concentrated in vacuo (below $23^{\circ} \mathrm{C}$ ) to afford a crude oil, which was used for the next step without further purification.

To a solution of triethyl phosphonoacetate $(65 \mathrm{~mL}, 328 \mathrm{mmol}, 1.1$ equiv. $)$ in dry THF (700 mL) at 0 ${ }^{\circ} \mathrm{C}$ was added $\mathrm{NaH}$ (60\% dispersion in mineral oil, $13.12 \mathrm{~g}, 328 \mathrm{mmol}, 1.1$ equiv.) in five batches over 20 minutes. After stirring at this temperature for 30 minutes, the aldehyde $\mathbf{S} 4$ was added dropwise. After 30 minutes, the reaction was warmed to $23^{\circ} \mathrm{C}$ and excess reagents were quenched with saturated aq. $\mathrm{NH}_{4} \mathrm{Cl}(400 \mathrm{~mL})$ and the resulting mixture was extracted with $\mathrm{Et}_{2} \mathrm{O}(3 \times 300 \mathrm{~mL})$. The organic layers were combined, washed with $\mathrm{H}_{2} \mathrm{O}(500 \mathrm{~mL})$, brine $(500 \mathrm{~mL})$, dried $\left(\mathrm{Na}_{2} \mathrm{SO}\right)$, 
filtered and concentrated in vacuo (below $20^{\circ} \mathrm{C}$ ) to afford a crude oil, which was purified by flash chromatography (Petroleum ether/Ethyl acetate $=50 / 1)$ to afford S5 as a colerless oil $(20.8 \mathrm{~g}, 42 \%$ for 3 steps).

Data of alcohol S5: ${ }^{1} \mathrm{H}$ NMR $\left(400 \mathrm{MHz}, \mathrm{CDCl}_{3}\right) \delta 6.72(\mathrm{~d}, J=15.6 \mathrm{~Hz}, 1 \mathrm{H}), 5.99(\mathrm{dd}, J=17.1$, $10.5 \mathrm{~Hz}, 1 \mathrm{H}), 5.76(\mathrm{~d}, J=15.6 \mathrm{~Hz}, 1 \mathrm{H}), 5.12-4.97(\mathrm{~m}, 2 \mathrm{H}), 4.16(\mathrm{q}, J=7.1 \mathrm{~Hz}, 2 \mathrm{H}), 1.27(\mathrm{t}, J=7.1$ $\mathrm{Hz}, 3 \mathrm{H}), 1.10-1.08(\mathrm{~m}, 2 \mathrm{H}), 1.01-0.98(\mathrm{~m}, 2 \mathrm{H})$; ${ }^{13} \mathrm{C}$ NMR $\left(100 \mathrm{MHz}, \mathrm{CDCl}_{3}\right) \delta$ 166.8, 153.9, 138.3, 117.9, 114.3, 60.1, 25.3, 17.0, 14.3;

IR (film, $\mathrm{cm}^{-1}$ ) 2982, 1714, 1643, 1162, 1036, 984;

HRMS(EI) [M] calculated for $\mathrm{C}_{10} \mathrm{H}_{14} \mathrm{O}_{2}: 166.0994$, found: 166.0989 ;

TLC: $\mathrm{Rf}=0.43($ Petroleum ether/Ethyl acetate $=10 / 1)$.

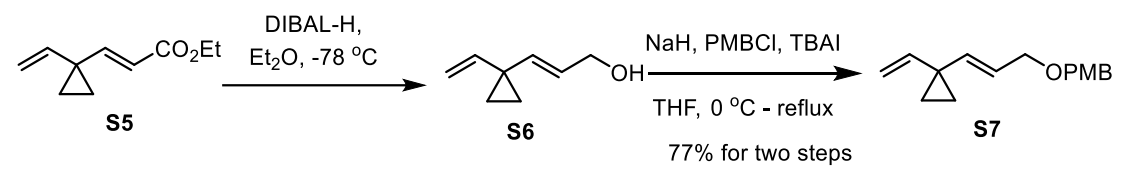

To a solution of $\mathbf{S} 5\left(20 \mathrm{~g}, 208 \mathrm{mmol}, 1.0\right.$ equiv.) in $\mathrm{CH}_{2} \mathrm{Cl}_{2}(650 \mathrm{~mL})$ at $-78{ }^{\circ} \mathrm{C}$ was added $1.0 \mathrm{M}$ DIBAL-H in hexane (458 mL, $458 \mathrm{mmol}, 2.2$ equiv.) dropwise over 30 minutes. The solution was stirred at this temperature until the consumption of starting material was observed by TLC, at which point the excess reagents were quenched by careful addition of water $(100 \mathrm{~mL})$. The reaction was allowed to warm to $23^{\circ} \mathrm{C}$, then saturated aq. potassium sodium tartrate $(1.3 \mathrm{~L})$ was added and the mixture was stirred vigorously for 1 hour. The phases were then separated, and the aqueous phase was extracted with $\mathrm{Et}_{2} \mathrm{O}(3 \times 300 \mathrm{~mL})$, the combined organic phases were dried over anhydrous $\mathrm{Na}_{2} \mathrm{SO}_{4}$, filtered and concentrated in vacuo to afford a crude oil, which was used directly in the next step.

To a solution of alcohol $\mathbf{S 6}$ in THF $(260 \mathrm{~mL})$ at $0{ }^{\circ} \mathrm{C}, \mathrm{NaH}(8.7 \mathrm{~g}, 217.5 \mathrm{mmol}, 60 \%$ in mineral oil, 1.05 equiv.) was added followed by the addition of tetra- $n$-butyl ammonium iodide $(6.71 \mathrm{~g}, 18.1$ mmol, 0.09 equiv.). The solution was allowed to reach $23^{\circ} \mathrm{C}$ for $1 \mathrm{~h}$. 4-Methoxybenzyl chloride (29.4 $\mathrm{mL}, 218 \mathrm{mmol}, 1.05$ equiv.) was added and the reaction was heated to reflux for $8 \mathrm{~h}$. After quenching by cold water and the resulting mixture was extracted with $\mathrm{Et}_{2} \mathrm{O}$, the organic layer was washed with brine and dried over $\mathrm{Na}_{2} \mathrm{SO}_{4}$, concentrated in vacuo to afford a crude oil, which was purified by flash chromatography (Petroleum ether/Ethyl acetate $=50 / 1$ ) to afford $\mathbf{S} 7$ as a colorless oil $(38.4 \mathrm{~g}, 77 \%)$.

Data of S7: ${ }^{1} \mathrm{H}$ NMR (400 MHz, $\left.\mathrm{CDCl}_{3}\right) \delta 7.26(\mathrm{~d}, J=8.6 \mathrm{~Hz}, 2 \mathrm{H}), 6.87(\mathrm{~d}, J=8.6 \mathrm{~Hz}, 2 \mathrm{H}), 5.82$ (dd, $J=17.0,10.6 \mathrm{~Hz}, 1 \mathrm{H}$ ), 5.70 (d, $J=15.5 \mathrm{~Hz}, 1 \mathrm{H}$ ), 5.56 (dt, $J=15.5,6.1 \mathrm{~Hz}, 1 \mathrm{H}$ ), 4.98 (dd, $J=7.4,1.2 \mathrm{~Hz}, 1 \mathrm{H}) .4 .95(\mathrm{~s}, 1 \mathrm{H}), 4.43(\mathrm{~s}, 2 \mathrm{H}), 4.00-3.94(\mathrm{~m}, 2 \mathrm{H}), 3.79(\mathrm{~s}, 3 \mathrm{H}), 0.84(\mathrm{~s}, 4 \mathrm{H})$;

${ }^{13} \mathrm{C}$ NMR $(100 \mathrm{MHz}, \mathrm{CDCl} 3) \delta 159.1,141.6,137.3,130.4,129.3,124.6,113.7,112.3,71.5$, 70.4, 55.3, 24.4, 15.2; 
IR (film, cm-1) 2836, 1612, 1512, 1245, 1034, 819;

HRMS(ESI) $[\mathrm{M}+\mathrm{H}]^{+}$calculated for $\mathrm{C}_{16} \mathrm{H}_{21} \mathrm{O}_{2}: 245.1536$, found: 245.1535 ;

TLC: $R f=0.47($ Petroleum ether/Ethyl acetate $=10 / 1)$.

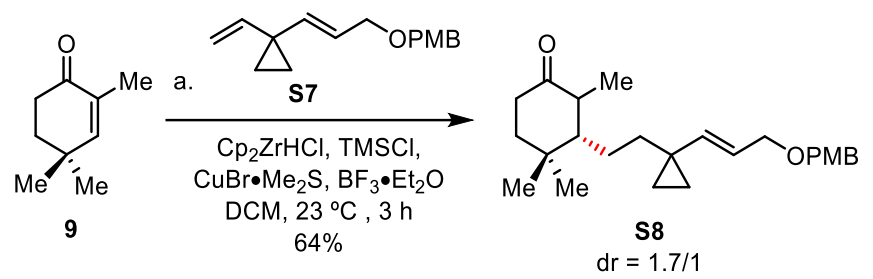

To a stirred solution of alkene $\mathbf{S} 7(2.3 \mathrm{~g}, 9.42 \mathrm{mmol}, 4.0$ equiv.) in $40 \mathrm{~mL}$ dry dichloromethane was added $\mathrm{Cp}_{2} \mathrm{ZrHCl}\left(1.94 \mathrm{~g}, 7.53 \mathrm{mmol}, 3.2\right.$ equiv.) at $23^{\circ} \mathrm{C}$ and stirred for $20 \mathrm{~min}$, then $\mathrm{CuBr} \cdot \mathrm{Me}_{2} \mathrm{~S}$ (484 mg, $2.354 \mathrm{mmol}, 1.0$ equiv.) was added and stirred for additional $40 \mathrm{~min}$. Then enone 9 (352 uL, $2.354 \mathrm{mmol}, 1.0$ equiv.) was added dropwise. $5 \mathrm{~min}$ later, chlorotrimethylsilane (1.02 $\mathrm{mL}, 11.77$ mmol, 5.0 equiv.) and $\mathrm{BF}_{3} \cdot \mathrm{Et}_{2} \mathrm{O}$ (290 uL, $2.354 \mathrm{mmol}, 1.0$ equiv.) was added. After $3 \mathrm{~h}$, the excess reagents were quenched by saturated aqueous $\mathrm{NH}_{4} \mathrm{Cl}$ solution $(50 \mathrm{~mL})$, the resulting mixture was extracted with dichloromethane $(30 \mathrm{~mL} \times 3)$, washed with brine $(30 \mathrm{~mL})$. The combined organic phases were dried over anhydrous $\mathrm{Na}_{2} \mathrm{SO}_{4}$, concentrated in vacuo to afford a crude oil, which was purified by flash chromatography (Petroleum ether/Ethyl acetate $=10 / 1$ ) to afford $\mathbf{S} 8$ as a yellow oil (583 mg, 64\%).

Data of S8: ${ }^{1} \mathrm{H}$ NMR $\left(400 \mathrm{MHz}, \mathrm{CDCl}_{3}\right) \delta 7.26(\mathrm{~d}, J=8.4 \mathrm{~Hz}, 2 \mathrm{H}), 6.87(\mathrm{~d}, J=8.6 \mathrm{~Hz}, 2 \mathrm{H}), 5.52-$ $5.25(\mathrm{~m}, 2 \mathrm{H}), 4.43-4.41(\mathrm{~m}, 2 \mathrm{H}), 3.98-3.91(\mathrm{~m}, 2 \mathrm{H}), 3.80(\mathrm{~s}, 3 \mathrm{H}), 2.87-2.19(\mathrm{~m}, 3 \mathrm{H}), 1.85-1.65(\mathrm{~m}$, 1H), 1.65-1.44 (m, 3H), 1.39-1.29 (m, 3H), 1.07-0.95 (m, 9H), 0.65-0.46 (m, 4H);

${ }^{13} \mathrm{C}$ NMR $\left(100 \mathrm{MHz}, \mathrm{CDCl}_{3}\right) \delta 214.0,213.4,159.1,159.1,139.4,139.4,130.5,130.4,129.3,129.3$, 128.6, 123.1, 123.0, 113.9, 113.7, 71.4, 71.4, 70.6, 70.6, 55.2, 54.1, 53.3, 47.2, 44.9, 41.3, 38.7, $38.3,38.1,37.7,36.2,34.5,29.4,28.4,27.6,27.4,23.7,22.1,22.0,19.6,14.3,14.2,14.2,14.1$, 12.7, 12.5;

IR (film, $\left.\mathrm{cm}^{-1}\right)$ 2936, 2857, 1708, 1512,1246, 1035, 820;

HRMS(ESI) $[\mathrm{M}+\mathrm{H}]^{+}$calculated for $\mathrm{C}_{25} \mathrm{H}_{37} \mathrm{O}_{3}: 385.2737$, found: 385.2731 ;

TLC: $R f=0.23($ Petroleum ether/Ethyl acetate $=4 / 1)$.

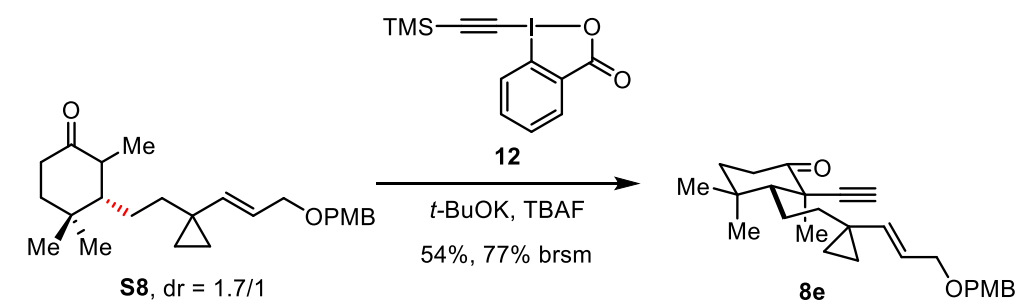

To a solution of $\mathbf{S} 8$ (523 mg, $1.36 \mathrm{mmol}, 1.0$ equiv.) in THF $(15 \mathrm{~mL})$ was added a solution of $t$-BuOK (1 $\mathrm{M}$ in THF, $1.36 \mathrm{~mL}, 1.36 \mathrm{mmol}, 1.0$ equiv.) at $23^{\circ} \mathrm{C}$. After $1 \mathrm{~h}$, the solution was cooled to $-78{ }^{\circ} \mathrm{C}$, TMS-EBX 12 (929 mg, 2.7 mmol, 1.99 equiv.) and TBAF (1 M in THF, $2.7 \mathrm{~mL}, 2.7$ mmol, 1.99 equiv.) 
were added sequentially. The reaction mixture was stirred for another $2.5 \mathrm{~h}$, the excess reagents were quenched by saturated aqueous $\mathrm{NH}_{4} \mathrm{Cl}$ solution $(20 \mathrm{~m} \mathrm{~L})$. The reaction mixture was extracted with ethyl acetate $(20 \mathrm{~mL} \times 3)$, washed with brine $(20 \mathrm{~mL})$. The combined organic phases were dried over anhydrous $\mathrm{Na}_{2} \mathrm{SO}_{4}$, concentrated in vacuo to afford a crude oil, which was purified by flash chromatography (Petroleum ether//Ethyl acetate $=25 / 1$ ) to afford $8 \mathbf{e}$ as a yellow oil $(300 \mathrm{mg}$, $54 \%)$ and recover $156 \mathrm{mg} \mathbf{S 8}(30 \%)$.

Data of 8e: ${ }^{1} \mathrm{H}$ NMR $\left(400 \mathrm{MHz}, \mathrm{CDCl}_{3}\right) \delta 7.26(\mathrm{~J}=8.4 \mathrm{~Hz}, 2 \mathrm{H}), 6.87(\mathrm{~d}, J=8.6 \mathrm{~Hz}, 2 \mathrm{H}), 5.57(\mathrm{dt}, J$ $=15.6,6.1 \mathrm{~Hz}, 1 \mathrm{H}), 5.46(\mathrm{~d}, J=15.6 \mathrm{~Hz}, 1 \mathrm{H}), 4.43(\mathrm{~s}, 2 \mathrm{H}), 3.96(\mathrm{~d}, J=6.1 \mathrm{~Hz}, 2 \mathrm{H}), 3.80(\mathrm{~s}, 3 \mathrm{H})$, 2.65 (ddd, $J=14.8,12.6,6.1 \mathrm{~Hz}, 1 \mathrm{H}), 2.41$ (dt, $J=14.8,4.5 \mathrm{~Hz}, 1 \mathrm{H}), 2.35$ (s, 1H), 1.76-1.47 (m, $7 \mathrm{H}), 1.42(\mathrm{~s}, 3 \mathrm{H}), 1.05(\mathrm{~s}, 3 \mathrm{H}), 1.02(\mathrm{~s}, 3 \mathrm{H}), 0.62-0.52(\mathrm{~m}, 4 \mathrm{H})$;

${ }^{13} \mathrm{C}$ NMR $\left(100 \mathrm{MHz}, \mathrm{CDCl}_{3}\right) \delta 209.5,159.1,139.7,130.5,129.3,123.0,113.7,87.1,72.1,71.4$, $70.7,55.3,54.8,50.6,39.8,39.2,34.4,34.3,31.9,25.5,22.3,22.0,21.5,14.5,14.4$;

IR (film, cm-1) 3288, 2924, 1717, 1512, 1246, 1035, 820, 637;

HRMS(ESI) $[\mathrm{M}+\mathrm{H}]^{+}$calculated for $\mathrm{C}_{27} \mathrm{H}_{37} \mathrm{O}_{3}: 409.2737$, found: 409.2738;

TLC: $\mathrm{Rf}=0.3($ Petroleum ether/Ethyl acetate $=5 / 1)$.

\subsection{Synthesis of $8 f \& 8 d \& 8 g$}

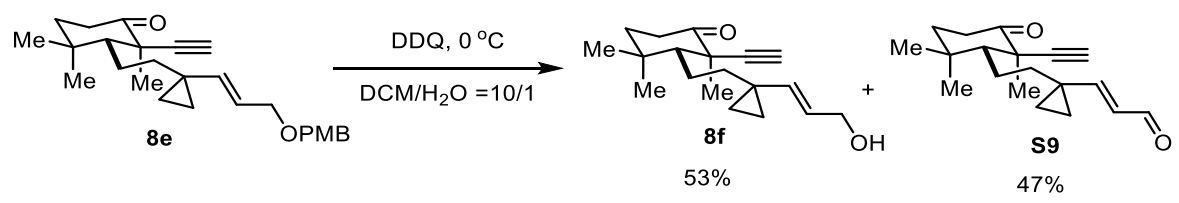

Substrate $8 \mathrm{e}$ (140 mg, $0.34 \mathrm{mmol}, 1.0$ equiv.) was dissolved in $10: 1$ mixture of $\mathrm{CH}_{2} \mathrm{Cl}_{2}: \mathrm{H}_{2} \mathrm{O}$ (30 $\mathrm{mL}: 3 \mathrm{~mL}$ ) and cooled to $0{ }^{\circ} \mathrm{C}$. Then, 2,3-dichloro-5,6-dicyano-1,4-benzo-quinone (DDQ) (115 mg, $0.51 \mathrm{mmol}, 1.5$ equiv.) was added. Upon completion indicated by TLC, the reaction was diluted in ethyl acetate $(10 \mathrm{~mL})$ and the excess reagents were quenched with saturated $\mathrm{NaHCO}_{3}$ solution (10 $\mathrm{mL})$. The reaction mixture was extracted with ethyl acetate, washed with brine $(10 \mathrm{~mL})$. The combined organic phases were dried over anhydrous $\mathrm{Na}_{2} \mathrm{SO}_{4}$, concentrated in vacuo to afford a crude oil, which was purified by flash chromatography (Petroleum ether//Ethyl acetate $=6 / 1$ to $4 / 1$ ) to afford $8 \mathrm{f}$ as a colorless solid ( $52 \mathrm{mg}, 53 \%$ ) and aldehyde $\mathbf{S 9}$ as a colorless solid (46 $\mathrm{mg}, 47 \%$ ).

Data of 8f: ${ }^{1} \mathrm{H}$ NMR $\left(600 \mathrm{MHz}, \mathrm{CDCl}_{3}\right) \delta 5.63(\mathrm{dt}, J=15.6,6.1 \mathrm{~Hz}, 1 \mathrm{H}), 5.44(\mathrm{dt}, J=15.6,1.2 \mathrm{~Hz}$, 1H), 4.11 (dd, $J=6.1,1.2 \mathrm{~Hz}, 2 \mathrm{H}$ ), 2.65 (ddd, $J=14.8,12.8,5.8 \mathrm{~Hz}, 1 \mathrm{H}$ ), 2.42 (dt, $J=14.8,4.6 \mathrm{~Hz}$, $1 \mathrm{H}), 2.36(\mathrm{~s}, 1 \mathrm{H}), 1.74-1.50(\mathrm{~m}, 8 \mathrm{H}), 1.43(\mathrm{~s}, 3 \mathrm{H}), 1.06(\mathrm{~s}, 3 \mathrm{H}), 1.03(\mathrm{~s}, 3 \mathrm{H}), 0.58(\mathrm{qd}, \mathrm{J}=9.3,3.3$ $\mathrm{Hz}, 4 \mathrm{H})$;

${ }^{13} \mathrm{C}$ NMR $\left(150 \mathrm{MHz}, \mathrm{CDCl}_{3}\right) \delta 209.4,138.5,125.5,87.2,72.1,63.9,54.8,50.6,39.8,39.2,34.4$, $34.3,31.9,25.5,22.2,22.0,21.5,14.6,14.4$;

IR (film, cm-1) 3463, 3305, 2954, 2866, 1716, 1456, 1392, 1376, 1142, 1087, 1014, 968; 
HRMS(ESI) $\left[\mathrm{M}+\mathrm{NH}_{4}\right]^{+}$calculated for $\mathrm{C}_{19} \mathrm{H}_{32} \mathrm{NO}_{2}: 306.2428$, found: 306.2425 ;

TLC: $\mathrm{Rf}=0.15($ Petroleum ether/Ethyl acetate $=4 / 1)$.

Data of S9: ${ }^{1} \mathrm{H}$ NMR $\left(400 \mathrm{MHz}, \mathrm{CDCl}_{3}\right) \delta 9.44(\mathrm{~d}, J=7.7 \mathrm{~Hz}, 1 \mathrm{H}), 6.36(\mathrm{~d}, J=15.7 \mathrm{~Hz}, 1 \mathrm{H}), 6.16$ (dd, $J=15.7,7.7 \mathrm{~Hz}, 1 \mathrm{H}), 2.65$ (td, $J=13.9,13.0,6.0 \mathrm{~Hz}, 1 \mathrm{H}), 2.43-2.35(\mathrm{~m}, 2 \mathrm{H}), 1.87-1.77$ (m, $1 \mathrm{H}), 1.74-1.53(\mathrm{~m}, 6 \mathrm{H}), 1.41(\mathrm{~s}, 3 \mathrm{H}), 1.05(\mathrm{~s}, 3 \mathrm{H}), 1.01(\mathrm{~s}, 3 \mathrm{H}), 0.99-0.89(\mathrm{~m}, 4 \mathrm{H})$;

${ }^{13} \mathrm{C}$ NMR $\left(100 \mathrm{MHz}, \mathrm{CDCl}_{3}\right) \delta 209.0,193.5,165.9,128.9,87.0,72.4,54.7,50.7,39.7,37.6,34.3$, 34.1, 32.0, 25.4, 24.6, 21.8, 21.4, 17.8, 17.6;

IR (film, $\mathrm{cm}^{-1}$ ) 2957, 2867, 2746, 1716, 1677, 1622, 1130, 938;

HRMS(ESI) $\left[\mathrm{M}+\mathrm{NH}_{4}\right]^{+}$calculated for $\mathrm{C}_{19} \mathrm{H}_{30} \mathrm{NO}_{2}: 304.2271$, found: 304.2268 ;

TLC: $\mathrm{Rf}=0.41($ Petroleum ether/Ethyl acetate $=4 / 1)$.

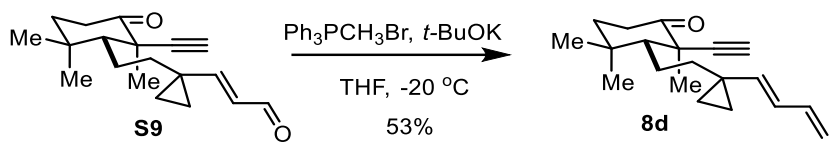

To a solution of $\mathrm{Ph}_{3} \mathrm{PCH}_{3} \mathrm{Br}(75 \mathrm{mg}, 0.21 \mathrm{mmol}, 1.9$ equiv.) in THF (15 mL) was added $t$-BuOK (1 $\mathrm{M}$ in THF, $210 \mathrm{uL}, 0.21 \mathrm{mmol}, 1.9$ equiv.) at $0{ }^{\circ} \mathrm{C}$ dropwise. The reaction was stirred at $0{ }^{\circ} \mathrm{C}$ for 15 min and warmed to $23^{\circ} \mathrm{C}$ for $45 \mathrm{~min}$ then cooled to $-20^{\circ} \mathrm{C}$. A solution of $\mathbf{S 9}(30 \mathrm{mg}, 0.11 \mathrm{mmol}, 1.0$ equiv.) in THF $(5 \mathrm{~mL})$ was added to the mixture dropwise at $-20^{\circ} \mathrm{C}$, and the reaction mixture was stirred at $-20^{\circ} \mathrm{C}$ for $1.5 \mathrm{~h}$. After the reaction was completed, the excess reagents were quenched by saturated aqueous $\mathrm{NH}_{4} \mathrm{Cl}$ solution $(20 \mathrm{~mL})$, the mixture was extracted with ethyl acetate $(20 \mathrm{~mL}$ $x 3$ ), washed with brine $(50 \mathrm{~mL})$. The combined organic phases were dried over anhydrous $\mathrm{Na}_{2} \mathrm{SO}_{4}$, concentrated in vacuo to afford a crude oil, which was purified by flash chromatography (Petroleum ether/Ether $=40 / 1$ to $20 / 1$ ) to afford $\mathbf{8 d}$ as a white solid $(15.9 \mathrm{mg}, 53 \%$ ).

Data of 8d: ${ }^{1} \mathrm{H}$ NMR $\left(500 \mathrm{MHz}, \mathrm{CDCl}_{3}\right) \delta 6.31(\mathrm{dt}, J=16.9,10.2 \mathrm{~Hz}, 1 \mathrm{H}), 6.07(\mathrm{dd}, J=15.4,10.4$ $\mathrm{Hz}, 1 \mathrm{H}$ ), 5.47 (d, J = 15.4 Hz, 1H), 5.07 (d, J=17.0 Hz, 1H), 4.96-4.91 (m, 1H), 2.65 (ddd, $J=14.8$, 12.6, 6.0 Hz, 1H), $2.42(\mathrm{dt}, \mathrm{J}=14.8,4.6 \mathrm{~Hz}, 1 \mathrm{H}), 2.36(\mathrm{~s}, 1 \mathrm{H}), 1.79-1.62(\mathrm{~m}, 5 \mathrm{H}), 1.62-1.53(\mathrm{~m}$, $1 \mathrm{H}), 1.50$ (dd, $J=12.5,4.9 \mathrm{~Hz}, 1 \mathrm{H}), 1.44(\mathrm{~s}, 3 \mathrm{H}), 1.06(\mathrm{~s}, 3 \mathrm{H}), 1.04(\mathrm{~s}, 3 \mathrm{H}), 0.66-0.59(\mathrm{~m}, 4 \mathrm{H})$;

${ }^{13} \mathrm{C}$ NMR $\left(126 \mathrm{MHz}, \mathrm{CDCl}_{3}\right) \delta 209.4,140.4,137.3,127.7,114.1,87.3,72.1,54.8,50.6,39.8,39.3$, $34.4,34.3,31.9,25.6,22.7,22.0,21.5,15.1,14.9$;

IR (film, $\mathrm{cm}^{-1}$ ) 2960, 1720, 1644, 1455, 1376, 1005, 895, 800, 636;

HRMS(ESI) $[\mathrm{M}+\mathrm{H}]^{+}$calculated for $\mathrm{C}_{20} \mathrm{H}_{29} \mathrm{O}: 285.2213$, found: 285.2207;

TLC: $\mathrm{Rf}=0.75($ Petroleum ether/Ethyl acetate $=8 / 1)$.

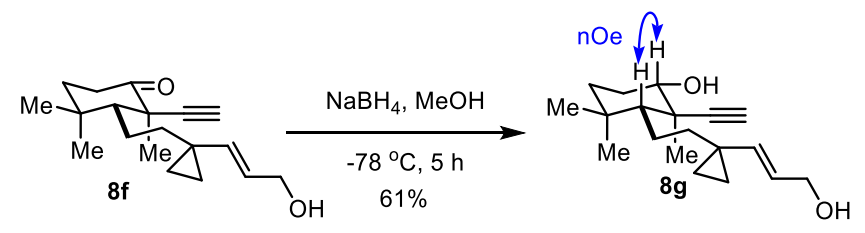


To a solution of ketone $\mathbf{8 f}(26 \mathrm{mg}, 0.09 \mathrm{mmol}, 1.0$ equiv. $)$ in $\mathrm{MeOH}(10 \mathrm{~mL})$ was added $\mathrm{NaBH}_{4}(6.8$ $\mathrm{mg}, 0.18 \mathrm{mmol}, 2.0$ equiv.) at $-78{ }^{\circ} \mathrm{C}$. After stirring at $-78{ }^{\circ} \mathrm{C}$ for $5 \mathrm{~h}$, the excess reagents were quenched by addition of saturated aqueous $\mathrm{NH}_{4} \mathrm{Cl}(10 \mathrm{~mL})$ and the resulting mixture was extracted with ethyl acetate $(3 \times 10 \mathrm{~mL})$. The combined organic phases were washed with brine $(10 \mathrm{~mL})$, dried over $\mathrm{Na}_{2} \mathrm{SO}_{4}$, filterred and concentrated in vacuo. The residue was purified on silica gel chromatography (Petroleum ether/Ethyl acetate $=4 / 1$ to $2 / 1$ ) to provide alcohol $\mathbf{8 g}$ as colorless oil (16 mg, 61\%).

Data of alcohol 8g: ${ }^{1} \mathrm{H}$ NMR $\left(500 \mathrm{MHz}, \mathrm{CDCl}_{3}\right) \delta 5.66(\mathrm{dt}, J=15.6,6.1 \mathrm{~Hz}, 1 \mathrm{H}), 5.44(\mathrm{~d}, J=$ $15.6 \mathrm{~Hz}, 1 \mathrm{H}), 4.11(\mathrm{dd}, J=6.1,1.1 \mathrm{~Hz}, 2 \mathrm{H}), 3.61(\mathrm{dd}, J=11.7,4.2 \mathrm{~Hz}, 1 \mathrm{H}), 2.16(\mathrm{~s}, 1 \mathrm{H}), 1.74$ (td, $J=14.5,13.7,4.3 \mathrm{~Hz}, 1 \mathrm{H}), 1.69-1.57(\mathrm{~m}, 3 \mathrm{H}), 1.56-1.46(\mathrm{~m}, 3 \mathrm{H}), 1.45-1.40(\mathrm{~m}, 1 \mathrm{H}), 1.30$ (dd, $J=13.7,3.8 \mathrm{~Hz}, 1 \mathrm{H}), 1.17(\mathrm{~s}, 3 \mathrm{H}), 1.15(\mathrm{t}, J=4.0 \mathrm{~Hz}, 1 \mathrm{H}), 0.88(\mathrm{~s}, 3 \mathrm{H}), 0.85(\mathrm{~s}, 3 \mathrm{H}), 0.66$ $-0.54(\mathrm{~m}, 4 \mathrm{H})$;

${ }^{13} \mathrm{C}$ NMR $\left(126 \mathrm{MHz}, \mathrm{CDCl}_{3}\right) \delta 138.9,125.4,92.2,77.8,69.1,64.0,52.7,43.3,39.8,39.3,34.3$, 32.9, 25.6, 25.1, 22.2, 22.0, 15.3, 14.7, 14.5;

IR (film, cm-1) 3304, 2993, 2940, 2867, 1460, 1389, 1088, 1017, 968;

HRMS(ESI) $\left[\mathrm{M}+\mathrm{NH}_{4}\right]^{+}$calculated for $\mathrm{C}_{19} \mathrm{H}_{34} \mathrm{NO}_{2}: 308.2584$, found: 308.2581 ;

TLC: $\mathrm{Rf}=0.13($ Petroleum ether/Ethyl acetate $=4 / 1)$.

\subsection{Synthesis of $8 \mathrm{~h} \& 8 \mathrm{i}$}

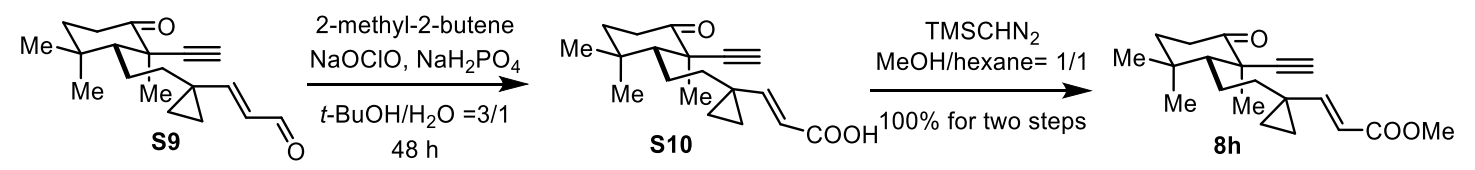

To a stirred solution of aldehyde $\mathbf{S 9}\left(10 \mathrm{mg}, 0.035 \mathrm{mmol}, 1.0\right.$ equiv.) in $t-\mathrm{BuOH}(1.5 \mathrm{~mL})$ at $23^{\circ} \mathrm{C}$ was added 2-methyl-2-butene ( $0.3 \mathrm{~mL}, 3.5 \mathrm{mmol}, 10.0$ equiv.). To the resulting mixture was added a solution of $\mathrm{NaH}_{2} \mathrm{PO}_{4}\left(43 \mathrm{mg}, 0.24 \mathrm{mmol}, 6.9\right.$ equiv.) and $\mathrm{NaClO}_{2}(80 \% \mathrm{wt} / \mathrm{wt}, 7.4 \mathrm{mg}, 0.084 \mathrm{mmol}$, 2.4 equiv.) in $\mathrm{H}_{2} \mathrm{O}(0.5 \mathrm{~mL})$. The resulting mixture was stirred for $48 \mathrm{~h}$ before the excess reagents were quenched with water $(2 \mathrm{~mL})$ and diluted with EtOAc $(2 \mathrm{~mL})$. The layers were then separated and the aqueous layer was extracted with EtOAc $(2 \times 3 \mathrm{~mL})$. The combined organic phases were washed with brine $(10 \mathrm{~mL})$, dried over $\mathrm{Na}_{2} \mathrm{SO}_{4}$, filterred and concentrated in vacuo. The crude residue $\mathbf{S} 10$ was directed used in the next step.

To a solution of $\mathbf{S 1 0}$ (from last step) in hexane $(1 \mathrm{~mL})$ and $\mathrm{MeOH}(1 \mathrm{~mL})$ was added a solution of $\mathrm{TMSCHN}_{2}$ (2M in hexane, $16.5 \mu \mathrm{L}, 0.033 \mathrm{mmol}, 0.94$ equiv.). The solution was stirred at $23^{\circ} \mathrm{C}$ for 90 minutes and the excess reagents were quenched with $\mathrm{AcOH}$ until no bubbles came out. The volatiles were removed in vacuo and the residue was purified on silica gel chromatography (Petroleum ether/Ethyl acetate $=6 / 1)$ to provide ester $\mathbf{8} \mathbf{h}$ as colorless oil $(11 \mathrm{mg}, 100 \%)$. 
Data of ester 8h: ${ }^{1} \mathrm{H}$ NMR (400 MHz, $\left.\mathrm{CDCl}_{3}\right) \delta 6.57(\mathrm{~d}, J=15.8 \mathrm{~Hz}, 1 \mathrm{H}), 5.86(\mathrm{~d}, J=15.8 \mathrm{~Hz}$, $1 \mathrm{H}), 3.72(\mathrm{~s}, 3 \mathrm{H}), 2.67$ (ddd, $J=14.7,12.8,6.1 \mathrm{~Hz}, 1 \mathrm{H}), 2.44-2.36(\mathrm{~m}, 2 \mathrm{H}), 1.86-1.78(\mathrm{~m}, 1 \mathrm{H})$, 1.76-1.61 (m, 4H), 1.57 (dt, J = 7.8, $4.4 \mathrm{~Hz}, 2 \mathrm{H}), 1.43(\mathrm{~s}, 3 \mathrm{H}), 1.06(\mathrm{~s}, 3 \mathrm{H}), 1.03(\mathrm{~s}, 3 \mathrm{H}), 0.83$ (m, 4H);

${ }^{13} \mathrm{C} \mathrm{NMR}\left(126 \mathrm{MHz}, \mathrm{CDCl}_{3}\right) \delta$ 209.2, 167.5, 155.8, 116.7, 87.1, 72.4, 54.8, 51.4, 50.7, 39.8, 37.9, 34.3, 34.2, 32.0, 25.4, 23.6, 21.9, 21.5, 16.6, 16.6;

IR (film, $\left.\mathrm{cm}^{-1}\right)$ 2954, 1719, 1642, 1434, 1313, 1264, 1170, 1020, 800;

HRMS(ESI) $[\mathrm{M}+\mathrm{H}]^{+}$calculated for $\mathrm{C}_{20} \mathrm{H}_{29} \mathrm{O}_{3}: 317.2112$, found: 317.2109 ;

TLC: $\mathrm{Rf}=0.67$ (Petroleum ether/Ethyl acetate $=3 / 1)$.

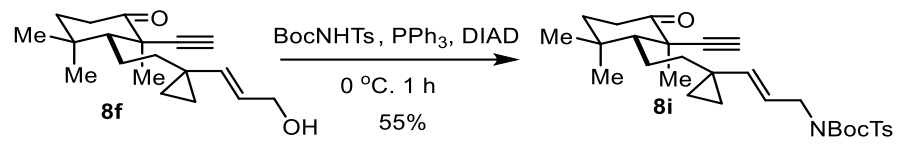

To a solution of $8 \mathbf{f}(9.0 \mathrm{mg}, 0.031 \mathrm{mmol}, 1.0$ equiv.), triphenyl phosphine $(20 \mathrm{mg}, 0.0762 \mathrm{mmol}, 2.45$ equiv.) and N-Boc p-toluenesulfonamide (12.7 mg, $0.047 \mathrm{mmol}, 1.5$ equiv.) in THF (2 mL) was added diisopropyl azodicarboxylate $(15.4 \mu \mathrm{L}, 0.078 \mathrm{mmol}, 2.5$ equiv. $)$. After being stirred at $0{ }^{\circ} \mathrm{C}$ for $1 \mathrm{~h}$, the resulting mixture was concentrated in vacuo to give a yellow oil. The residue was purified by column chromatography (Petroleum ether/Ethyl acetate $=15 / 1$ to $10 / 1)$ to give $8 \mathbf{i}(9.5 \mathrm{mg}, 55 \%)$ as colorless oil.

Data of 8i: ${ }^{1} \mathrm{H}$ NMR $\left(500 \mathrm{MHz}, \mathrm{CDCl}_{3}\right) \delta 7.78(\mathrm{~d}, J=8.3 \mathrm{~Hz}, 2 \mathrm{H}), 7.28(\mathrm{~d}, J=8.1 \mathrm{~Hz}, 2 \mathrm{H}), 5.63$ $-5.49(\mathrm{~m}, 2 \mathrm{H}), 4.41$ (d, J = 5.9 Hz, 2H), 2.64 (ddd, J = 14.7, 12.8, $6.0 \mathrm{~Hz}, 1 \mathrm{H}$ ), $2.42(\mathrm{~s}, 3 \mathrm{H})$, 2.42-2.38 (m, 1H), $2.38(\mathrm{~s}, 1 \mathrm{H}), 1.75-1.60(\mathrm{~m}, 5 \mathrm{H}), 1.57-1.52(\mathrm{~m}, 2 \mathrm{H}), 1.40(\mathrm{~s}, 3 \mathrm{H}), 1.33(\mathrm{~s}$, $9 \mathrm{H}), 1.03(\mathrm{~s}, 3 \mathrm{H}), 1.01(\mathrm{~s}, 3 \mathrm{H}), 0.61(\mathrm{~m}, 4 \mathrm{H})$;

${ }^{13} \mathrm{C}$ NMR $\left(126 \mathrm{MHz}, \mathrm{CDCl}_{3}\right) \delta 209.4,150.8,143.9,140.8,137.6,129.1,128.1,121.5,87.0,84.0$, 72.4, 54.8, 50.7, 48.5, 39.9, 39.2, 34.4, 34.3, 31.9, 27.9, 25.5, 22.3, 21.9, 21.6, 21.5, 14.6, 14.3;

IR (film, $\mathrm{cm}^{-1}$ ) 2960, 2926, 2867, 1720, 1358, 1154, 1088, 672, 584;

HRMS(ESI) $\left[\mathrm{M}+\mathrm{NH}_{4}\right]^{+}$calculated for $\mathrm{C}_{31} \mathrm{H}_{47} \mathrm{~N}_{2} \mathrm{O}_{5}: 559.3200$, found: 559.3194;

TLC: $\mathrm{Rf}=0.58($ Petroleum ether/Ethyl acetate $=6 / 1)$. 


\section{Experimental details for the Rh-catalyzed [3+2+1] cycloaddition/Pd-mediated cycloalkenylation (Scheme 2)}

\subsection{Experiment procedures and characterization data for the Rh-catalyzed $[3+2+1]$ cycloaddtion}

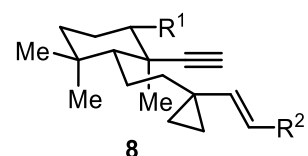

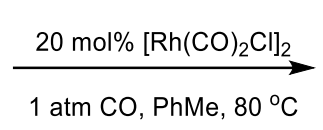

1 atm CO, PhMe, $80^{\circ} \mathrm{C}$

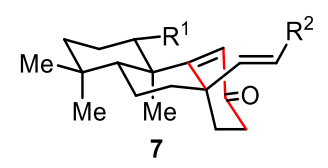

General procedure A: A solution of 1-yne-VCP substrate 7 and $\left[\mathrm{Rh}(\mathrm{CO})_{2} \mathrm{Cl}\right]_{2}(78 \mathrm{mg}$ per mmol substrate, $20 \mathrm{~mol} \%)$ in anhydrous toluene $(20 \mathrm{~mL}$ per mmol) was degassed by bubbling CO for 10 $\min$. Then the reaction mixture was immersed in an $80^{\circ} \mathrm{C}$ oil bath and stirred under the above atmosphere. When TLC indicated the disappearance of the starting material, the reaction mixture was cooled to $23^{\circ} \mathrm{C}$ and concentrated in vacuo. The crude mixture was submitted to flash column chromatography on silica gel to afford the corresponding product.

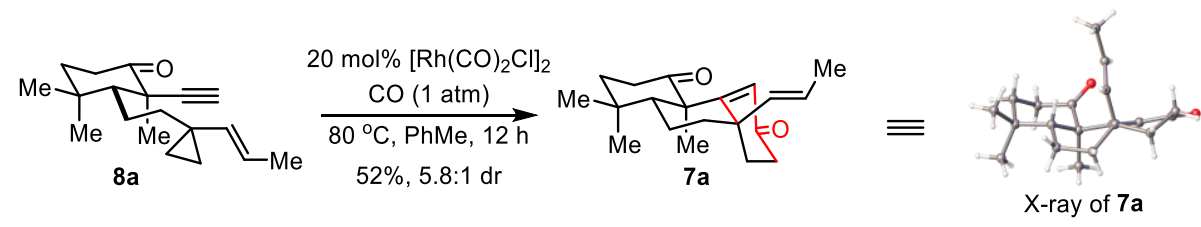

Following the general procedure A, 1-yne-VCP $8 \mathrm{a}(300 \mathrm{mg}, 1.1 \mathrm{mmol})$ was converted to enone $7 \mathrm{a}$ (172 $\mathrm{mg}, 52 \%$ ) in $12 \mathrm{~h}$ as a $5.8: 1$ mixture of diastereomers that was purified by flash chromatography (Petroleum ether/Ethyl acetate $=7 / 1$ ). This mixture was futher purified by flash chromatography (Petroleum ether/Ethyl acetate $=20 / 1)$ to obatain pure $7 a(140 \mathrm{mg}, 43 \%)$ and $7 \mathrm{a}$ ' (20 mg, 6\%).

Single crystals of 7 a suitable for X-ray crystallographic analysis were obtained by a single recrystallization at $23{ }^{\circ} \mathrm{C}$ using $n$-hexane/ $\mathrm{CHCl}_{3}$ as a solvent by slow evaporation. The relative configuration was determined by X-ray crystallographic analysis. See S112.

Data of 7a: ${ }^{1} \mathrm{H}$ NMR $\left(400 \mathrm{MHz}, \mathrm{CDCl}_{3}\right) \delta 6.25(\mathrm{~s}, 1 \mathrm{H}), 5.42-5.27(\mathrm{~m}, 2 \mathrm{H}), 2.68$ (ddd, $J=13.6,10.1$, $4.9 \mathrm{~Hz}, 1 \mathrm{H}), 2.51-2.39(\mathrm{~m}, 1 \mathrm{H}), 2.40-2.27(\mathrm{~m}, 2 \mathrm{H}), 2.17(\mathrm{dt}, J=11.4,8.5 \mathrm{~Hz}, 1 \mathrm{H}), 1.92-1.86(\mathrm{~m}$, $1 \mathrm{H}), 1.85-1.81(\mathrm{~m}, 1 \mathrm{H}), 1.80-1.75(\mathrm{~m}, 1 \mathrm{H}), 1.74-1.69(\mathrm{~m}, 3 \mathrm{H}), 1.64(\mathrm{dd}, J=3.3,1.3 \mathrm{~Hz}, 3 \mathrm{H}), 1.61-$ $1.58(\mathrm{~m}, 1 \mathrm{H}), 1.57-1.51(\mathrm{~m}, 1 \mathrm{H}), 1.44(\mathrm{~s}, 3 \mathrm{H}), 1.04(\mathrm{~s}, 3 \mathrm{H}), 0.91(\mathrm{~s}, 3 \mathrm{H})$;

${ }^{13} \mathrm{C} \mathrm{NMR}\left(100 \mathrm{MHz}, \mathrm{CDCl}_{3}\right) \delta$ 211.3, 200.4, 167.0, 134.8, 129.9, 126.7, 53.4, 42.8, 41.9, 40.5, 37.9, $36.1,33.0,32.9,32.7,31.5,24.8,23.0,17.9,17.6$;

IR (film, cm-1) 2948, 1711, 1669, 1448, 1334 1256, 980;

HRMS(ESI) $[\mathrm{M}+\mathrm{H}]^{+}$calculated for $\mathrm{C}_{20} \mathrm{H}_{29} \mathrm{O}_{2}: 301.2162$, found: 301.2167 . 
TLC: $\mathrm{Rf}=0.20($ Petroleum ether/Ethyl acetate $=8 / 1)$.

Data of 7a': ${ }^{1} \mathrm{H}$ NMR $\left(400 \mathrm{MHz}, \mathrm{CDCl}_{3}\right) \delta 6.26(\mathrm{~s}, 1 \mathrm{H}), 5.54(\mathrm{~m}, 1 \mathrm{H}), 5.41(\mathrm{dd}, J=15.8,1.3 \mathrm{~Hz}$, 1H), 2.63 (ddd, $J=14.6,13.6,4.6 \mathrm{~Hz}, 1 \mathrm{H}$ ), 2.49 (ddd, $J=17.3,14.7,5.2 \mathrm{~Hz}, 1 \mathrm{H}$ ), 2.30 (ddd, $J=$ 13.5, 4.5, $2.9 \mathrm{~Hz}, 1 \mathrm{H}), 2.25-2.14(\mathrm{~m}, 2 \mathrm{H}), 1.92-1.82(\mathrm{~m}, 1 \mathrm{H}), 1.81-1.74(\mathrm{~m}, 2 \mathrm{H}), 1.74-1.69(\mathrm{~m}, 3 \mathrm{H})$, 1.69 -1.66 (m, 1H), 1.65-1.59 (m, 2H), 1.51-1.42 (m, 2H), $1.31(\mathrm{~s}, 3 \mathrm{H}), 1.06(\mathrm{~s}, 3 \mathrm{H}), 0.95(\mathrm{~s}, 3 \mathrm{H})$; ${ }^{13} \mathrm{C}$ NMR $\left(100 \mathrm{MHz}, \mathrm{CDCl}_{3}\right) \delta 214.3,200.8,164.6,134.8,126.5,126.2,54.0,50.9,42.0,41.2,39.9$, $37.5,36.4,33.1,32.2,31.0,25.8,23.8,19.7,18.0$;

IR (film, $\mathrm{cm}^{-1}$ ) 2931, 1707, 1668, 1467, 1324 1262, 1018, 975;

HRMS(ESI) $[\mathrm{M}+\mathrm{H}]^{+}$calculated for $\mathrm{C}_{20} \mathrm{H}_{29} \mathrm{O}_{2}: 301.2162$, found: 301.2157 ;

TLC: $\mathrm{Rf}=0.20($ Petroleum ether/Ethyl acetate $=8 / 1)$.

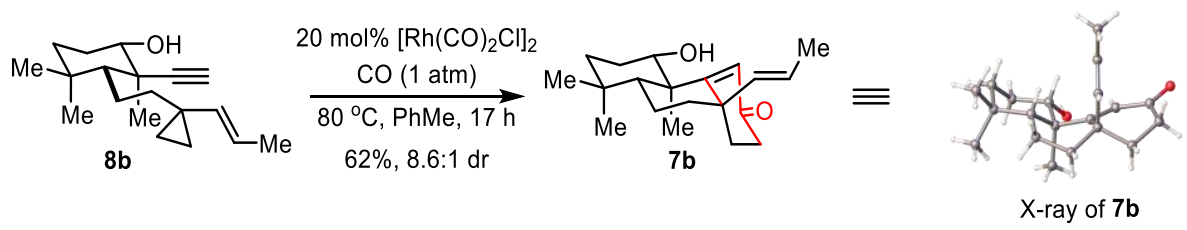

Following the general procedure A, 1-yne-VCP $8 \mathbf{b}(15 \mathrm{mg}, 0.055 \mathrm{mmol})$ was converted to enone $7 \mathrm{~b}(10.3 \mathrm{mg}, 62 \%)$ in $17 \mathrm{~h}$ as a $8.3: 1$ mixture of diastereomers that was purified by flash chromatography (Petroleum ether/Ethyl acetate $=4 / 1$ to $2 / 1$ ).

Single crystals of $\mathbf{7 b}$ suitable for X-ray crystallographic analysis were obtained by a single recrystallization at $23{ }^{\circ} \mathrm{C}$ using $n$-hexane/ $\mathrm{CHCl}_{3}$ as a solvent by slow evaporation. The relative configuration was determined by X-ray crystallographic analysis. See S113.

Data of $7 \mathbf{b}:{ }^{1} \mathrm{H}$ NMR $\left(500 \mathrm{MHz}, \mathrm{CDCl}_{3}\right) \delta 7.18(\mathrm{~s}, 1 \mathrm{H}), 5.57-5.27(\mathrm{~m}, 2 \mathrm{H}), 3.61(\mathrm{dd}, J=10.5,5.5$ $\mathrm{Hz}, 1 \mathrm{H}), 2.52-2.37(\mathrm{~m}, 1 \mathrm{H}), 2.26-2.10(\mathrm{~m}, 1 \mathrm{H}), 1.86-1.49(\mathrm{~m}, 13 \mathrm{H}), 1.38(\mathrm{dt}, \mathrm{J}=13.4,3.5 \mathrm{~Hz}, 1 \mathrm{H})$, 1.23-1.17(m, 1H), $1.20(\mathrm{~s}, 3 \mathrm{H}), 0.89(\mathrm{~s}, 3 \mathrm{H}), 0.78(\mathrm{~s}, 3 \mathrm{H})$;

${ }^{13} \mathrm{C}$ NMR $\left(126 \mathrm{MHz}, \mathrm{CDCl}_{3}\right) \delta 202.4,177.3,135.3,126.9,126.1,77.0,45.1,42.4,41.5,39.7,38.2$, $33.5,33.3,32.4,31.8,30.2,20.9,18.4,17.9,17.8$;

IR (film, cm-1) 3401, 2924, 2853, 1649, 1591, 1455, 1355, 1259, 1044, 987, 754;

HRMS(ESI) $[\mathrm{M}+\mathrm{H}]^{+}$calculated for $\mathrm{C}_{20} \mathrm{H}_{31} \mathrm{O}_{2}: 303.2319$, found: 303.2311 ;

TLC: $\mathrm{Rf}=0.67($ Petroleum ether/Ethyl acetate $=1 / 1)$.
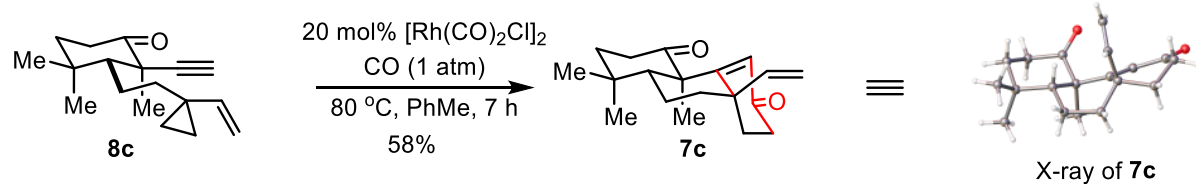

Following the general procedure A, 1-yne-VCP 8c (13 mg, $0.05 \mathrm{mmol}$ ) was converted to enone 7c $(8.4 \mathrm{mg}, 58 \%)$ in $7 \mathrm{~h}$ as a single diastereomer that was purified by flash chromatography (Petroleum 
ether/Ethyl acetate $=7 / 1$ to $5 / 1$ ).

Single crystals of 7c suitable for X-ray crystallographic analysis were obtained by a single recrystallization at $23{ }^{\circ} \mathrm{C}$ using $n$-hexane/ $\mathrm{CHCl}_{3}$ as a solvent by slow evaporation. The relative configuration was determined by X-ray crystallographic analysis. See S114.

Data of 7c: ${ }^{1} \mathrm{H}$ NMR $\left(400 \mathrm{MHz}, \mathrm{CDCl}_{3}\right) \delta 6.30(\mathrm{~s}, 1 \mathrm{H}), 5.78(\mathrm{dd}, J=17.5,10.5 \mathrm{~Hz}, 1 \mathrm{H}), 5.14(\mathrm{~d}, J$ $=10.5 \mathrm{~Hz}, 1 \mathrm{H}), 4.99(\mathrm{~d}, J=17.5 \mathrm{~Hz}, 1 \mathrm{H}), 2.69(\mathrm{ddd}, J=13.7,10.0,5.0 \mathrm{~Hz}, 1 \mathrm{H}), 2.48(\mathrm{ddd}, J=$ 17.1, 14.1, $5.6 \mathrm{~Hz}, 1 \mathrm{H}), 2.39-2.30(\mathrm{~m}, 2 \mathrm{H}), 2.20(\mathrm{dt}, J=17.0,3.0 \mathrm{~Hz}, 1 \mathrm{H}), 2.00-1.92(\mathrm{~m}, 1 \mathrm{H}), 1.91$ -1.79 (m, 1H), 1.77-1.58 (m, 6H), $1.46(\mathrm{~s}, 3 \mathrm{H}), 1.06(\mathrm{~s}, 3 \mathrm{H}), 0.92(\mathrm{~s}, 3 \mathrm{H})$;

${ }^{13} \mathrm{C} \mathrm{NMR}\left(126 \mathrm{MHz}, \mathrm{CDCl}_{3}\right) \delta 211.2,200.1,166.1,142.3,130.3,116.5,53.3,42.7,42.7,40.4,37.4$, $36.1,33.0,32.8,32.6,31.4,24.8,23.1,17.5$;

IR (film, $\mathrm{cm}^{-1}$ ) 2950, 2924, 1711, 1669, 1468, 1335, 1257, 1100, 1002, 925;

HRMS(ESI) $[\mathrm{M}+\mathrm{H}]^{+}$calculated for $\mathrm{C}_{19} \mathrm{H}_{27} \mathrm{O}_{2}: 287.2005$, found: 287.1998;

TLC: $\mathrm{Rf}=0.27($ Petroleum ether/Ethyl acetate $=8 / 1)$.

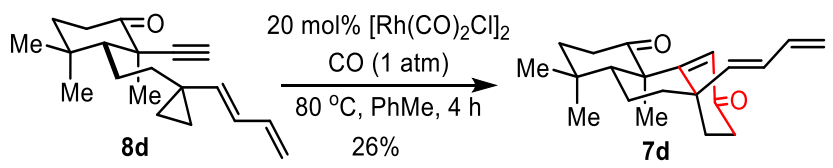

Following the general procedure A, 1-yne-VCP $8 \mathrm{~d}(14.2 \mathrm{mg}, 0.05 \mathrm{mmol})$ was converted to enone 7d $(4.1 \mathrm{mg}, 26 \%)$ in $4 \mathrm{~h}$ as a single diastereomer that was purified by flash chromatography $($ Petroleum ether/Ethyl acetate $=10 / 1$ to $5 / 1)$.

Data of $7 \mathrm{~d}:{ }^{1} \mathrm{H}$ NMR $\left(500 \mathrm{MHz}, \mathrm{CDCl}_{3}\right) \delta 6.33(\mathrm{~s}, 1 \mathrm{H}), 6.32-6.25(\mathrm{~m}, 1 \mathrm{H}), 5.95(\mathrm{dd}, J=15.7,10.3$ $\mathrm{Hz}, 1 \mathrm{H}), 5.63(\mathrm{~d}, J=15.7 \mathrm{~Hz}, 1 \mathrm{H}), 5.12(\mathrm{~d}, J=17.0 \mathrm{~Hz}, 1 \mathrm{H}), 5.03(\mathrm{~d}, \mathrm{~J}=10.2 \mathrm{~Hz}, 1 \mathrm{H}$ ), 2.68 (ddd, $J=13.7,9.9,4.9 \mathrm{~Hz}, 1 \mathrm{H}$ ), 2.44 (ddd, $J=17.0,14.2,5.5 \mathrm{~Hz}, 1 \mathrm{H}), 2.37-2.26(\mathrm{~m}, 2 \mathrm{H}), 2.21$ (dt, $J=$ 17.0, 3.0 Hz, 1H), 1.97 (ddd, $J=13.3,10.7,1.8 \mathrm{~Hz}, 1 \mathrm{H}), 1.89-1.81(\mathrm{~m}, 1 \mathrm{H}), 1.81-1.59(\mathrm{~m}, 6 \mathrm{H}), 1.47$ (s, 3H), $1.06(\mathrm{~s}, 3 \mathrm{H}), 0.91(\mathrm{~s}, 3 \mathrm{H})$.

${ }^{13} \mathrm{C}$ NMR $(126 \mathrm{MHz}, \mathrm{CDCl} 3) \delta 211.1,199.9,166.2,137.8,135.9,132.2,130.2,117.3,53.3,43.0$, $42.0,40.3,37.9,36.1,33.1,33.0,32.9,31.5,24.8,23.2,17.5$.

IR (film, cm ${ }^{-1}$ ) 2949, 2868, 1711, 1668, 1467, 1334, 1097, 1008, 899;

$\mathrm{HRMS}(\mathrm{ESI})[\mathrm{M}+\mathrm{H}]^{+}$calculated for $\mathrm{C}_{21} \mathrm{H}_{29} \mathrm{O}_{2}$ : 313.2162 , found: 313.2162 ;

TLC: $\mathrm{Rf}=0.24($ Petroleum ether $/$ Ethyl acetate $=10 / 1)$.

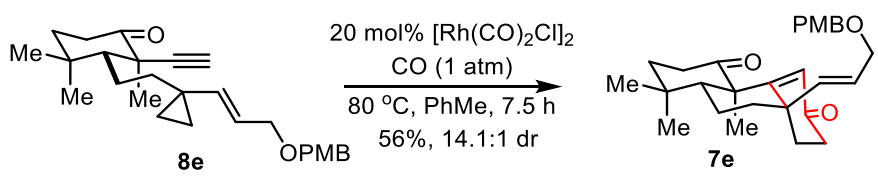

Following the general procedure A, 1-yne-VCP 8 e $(20 \mathrm{mg}, 0.05 \mathrm{mmol})$ was converted to enone $7 \mathbf{e}$ $(12.1 \mathrm{mg}, 62 \%)$ in $7.5 \mathrm{~h}$ as a $14.1: 1$ mixture of diastereomers that was purified by flash 
chromatography (Petroleum ether/Ethyl acetate $=4 / 1$ to $2 / 1$ ).

Data of 7e: ${ }^{1} \mathrm{H}$ NMR $\left(500 \mathrm{MHz}, \mathrm{CDCl}_{3}\right) \delta 7.22(\mathrm{~d}, J=8.6 \mathrm{~Hz}, 2 \mathrm{H}), 6.87(\mathrm{~d}, J=8.6 \mathrm{~Hz}, 2 \mathrm{H}), 6.30(\mathrm{~s}$, $1 \mathrm{H}), 5.69(\mathrm{~d}, J=15.9 \mathrm{~Hz}, 1 \mathrm{H}), 5.53(\mathrm{dt}, J=15.9,5.6 \mathrm{~Hz}, 1 \mathrm{H}), 4.40(\mathrm{~s}, 2 \mathrm{H}), 3.94(\mathrm{td}, J=4.6,1.2 \mathrm{~Hz}$, 2H), $3.80(\mathrm{~s}, 3 \mathrm{H}$ ), 2.67 (ddd, $J=13.7,10.0,4.8 \mathrm{~Hz}, 1 \mathrm{H}$ ), 2.45 (ddd, $J=17.0,14.0,5.7 \mathrm{~Hz}, 1 \mathrm{H}$ ), 2.39-2.31 (m, 2H), 2.20 (dt, J = 17.0, 3.0 Hz, 1H), 1.97 (ddd, $J=13.2,10.5,1.7 \mathrm{~Hz}, 1 \mathrm{H}$ ), 1.90-1.82 (m, 1H), 1.81-1.67 (m, 4H), 1.65-1.59 (m, 2H), $1.46(\mathrm{~s}, 3 \mathrm{H}), 1.05(\mathrm{~s}, 3 \mathrm{H}), 0.90(\mathrm{~s}, 3 \mathrm{H})$;

${ }^{13} \mathrm{C}$ NMR $\left(126 \mathrm{MHz}, \mathrm{CDCl}_{3}\right)$ б 211.2, 199.9, 166.3, 159.2, 136.8,130.3, 130.2, 129.1, 128.42, 113.8, 71.8, 69.6, 55.3, 53.3, 42.9, 41.8, 40.4, 37.7, 36.1, 33.0, 32.9, 32.8, 31.5, 24.8, 23.1, 17.5;

IR (film, cm ${ }^{-1}$ ) 2919, 2852, 1709, 1667, 1512, 1464, 1335, 1302, 1247, 1063, 1034, 820;

HRMS(ESI) $[\mathrm{M}+\mathrm{H}]^{+}$calculated for $\mathrm{C}_{28} \mathrm{H}_{37} \mathrm{O}_{4}: 437.2686$, found: 437.2679;

TLC: $R f=0.26($ Petroleum ether/Ethyl acetate $=1 / 4)$.
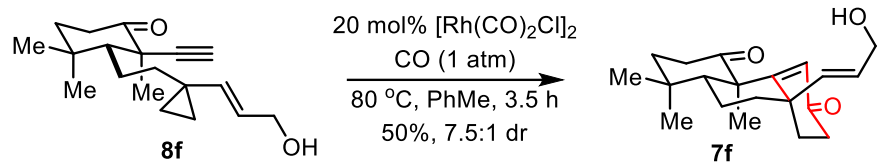

Following the general procedure A, 1-yne-VCP $8 f(15 \mathrm{mg}, 0.05 \mathrm{mmol}$ ) was converted to enone $7 \mathrm{e}$ (8.2 $\mathrm{mg}, 50 \%$ ) in $3.5 \mathrm{~h}$ as a $7.5: 1$ mixture of diastereomers that was purified by flash chromatography (Petroleum ether/Ethyl acetate $=1 / 1$ to $1 / 2$ ).

Data of 7f: ${ }^{1} \mathrm{H}$ NMR $\left(400 \mathrm{MHz}, \mathrm{CDCl}_{3}\right)$ ס 6.30-6.28 (m, 1H), 5.78-5.50 (m, 2H), 4.24-4.04 (m, 2H), 2.78-2.57 (m, 1H), 2.54-2.40 (m, 1H), 2.40-2.28 (m, 2H), 2.28-2.16 (m, 1H), 2.02-1.91 (m, 1H), 1.90 $-1.83(\mathrm{~m}, 1 \mathrm{H}), 1.83-1.69(\mathrm{~m}, 5 \mathrm{H}), 1.67-1.53(\mathrm{~m}, 2 \mathrm{H}), 1.47-1.34(\mathrm{~m}, 3 \mathrm{H}), 1.07(\mathrm{~s}, 3 \mathrm{H}), 0.95-0.93(\mathrm{~m}$, $3 \mathrm{H})$;

${ }^{13} \mathrm{C}$ NMR $\left(100 \mathrm{MHz}, \mathrm{CDCl}_{3}\right)$ ठ 214.3, 200.1, 166.5, 135.2, 130.8, 130.3, 62.8, 53.5, 43.1, 41.7, 40.5, 37.6, 36.1, 33.0, 32.9, 32.7, 31.5, 24.7, 23.0, 17.5;

IR (film, cm-1) 3409, 2947, 1708, 1657, 1512, 1465, 1336, 1202, 981, 898;

HRMS(ESI) $[\mathrm{M}+\mathrm{H}]^{+}$calculated for $\mathrm{C}_{20} \mathrm{H}_{29} \mathrm{O}_{3}: 317.2111$, found: 317.2107 ;

TLC: $\mathrm{Rf}=0.27($ Petroleum ether/Ethyl acetate $=1 / 1)$.
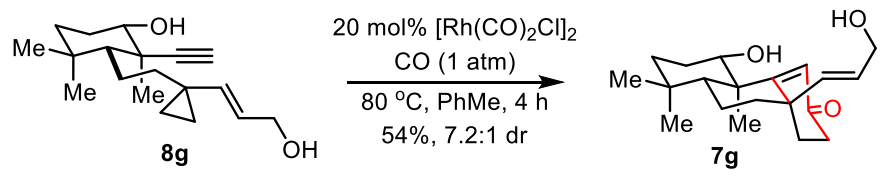

Following the general procedure A, 1-yne-VCP $8 \mathrm{~g}$ (14 $\mathrm{mg}, 0.05 \mathrm{mmol}$ ) was converted to enone $\mathbf{7 g}$ $(8.2 \mathrm{mg}, 50 \%)$ in $4 \mathrm{~h}$ as a $7.2: 1$ mixture of diastereomers that was purified by flash chromatography (Dichloromethane/Methanol= 200/1 to 50/1).

Data of $7 \mathrm{~g}:{ }^{1} \mathrm{H}$ NMR $\left(500 \mathrm{MHz}, \mathrm{CDCl}_{3}\right) \delta 7.21(\mathrm{~s}, 1 \mathrm{H}), 5.69-5.62(\mathrm{~m}, 2 \mathrm{H}), 4.15(\mathrm{~d}, J=4.1 \mathrm{~Hz}, 2 \mathrm{H})$, 3.64 (dd, $J=10.7,5.4 \mathrm{~Hz}, 1 \mathrm{H}$ ), 2.44 (ddd, $J=17.9,14.3,5.3 \mathrm{~Hz}, 1 \mathrm{H}), 2.26-2.18(\mathrm{~m}, 1 \mathrm{H}), 1.86-1.78$ 
(m, 3H), 1.74-1.57 (m, 8H), $1.38(\mathrm{dt}, J=13.5,3.4 \mathrm{~Hz}, 1 \mathrm{H}), 1.25-1.20(\mathrm{~m}, 1 \mathrm{H}), 1.21(\mathrm{~s}, 3 \mathrm{H}), 0.89(\mathrm{~s}$, $3 \mathrm{H}), 0.78(\mathrm{~s}, 3 \mathrm{H})$

${ }^{13} \mathrm{C}$ NMR $\left(126 \mathrm{MHz} \mathrm{CDCl}_{3}\right) \delta$ 202.1, 176.9, 136.2, 130.3, 127.2, 76.9, 63.1, 45.1, 42.2, 41.7, 39.7, 38.0, 33.5, 33.2, 32.4, 31.6, 30.1, 20.9, 18.4, 17.7.

IR (film, cm-1) 3400, 2945, 2867, 1647, 1590, 1457, 1337, 1043, 986, 732;

$\mathrm{HRMS}(E S I)[\mathrm{M}+\mathrm{H}]^{+}$calculated for $\mathrm{C}_{20} \mathrm{H}_{31} \mathrm{O}_{3}: 319.2267$, found: 319.2262 ;

TLC: $\mathrm{Rf}=0.25($ Dichloromethane/Methanol= 25/1).

\subsection{Experiment procedures and characterization data for the Pd-mediated cycloalkenylation}

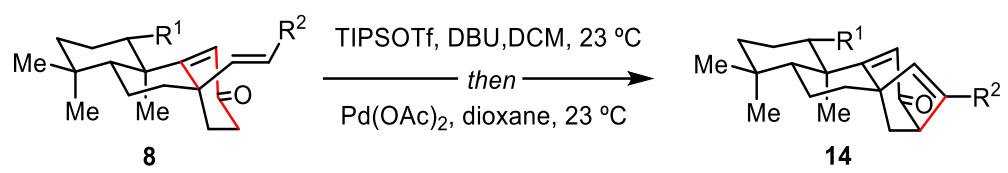

General procedure B: To a solution of enone 8 in DCM (60 mL per mmol) was added DBU (0.3 $\mathrm{mL}$ per mmol, 2 equiv. $)$ and TIPSOTf $(0.48 \mathrm{~mL}$ per mmol, 1.8 equiv. $)$ at $23^{\circ} \mathrm{C}$. After stirring at this temperature for $3 \mathrm{~h}$, dioxane $((60 \mathrm{~mL}$ per mmol $))$ and $\mathrm{Pd}(\mathrm{OAc})_{2}(1.12 \mathrm{~g}$ per mmol, 5 equiv.) were added. When TLC indicated the disappearance of the silyl enol ether, the excess reagents were quenched with saturated aq. $\mathrm{NH}_{4} \mathrm{Cl}$ solution and the resulting mixture was extracted with $\mathrm{DCM}$. The combined organic layers were washed with brine, dried over $\mathrm{Na}_{2} \mathrm{SO}_{4}$, filterred and concentrated in vacuo. The residue was purified on silica gel chromatography to afford the corresponding product.

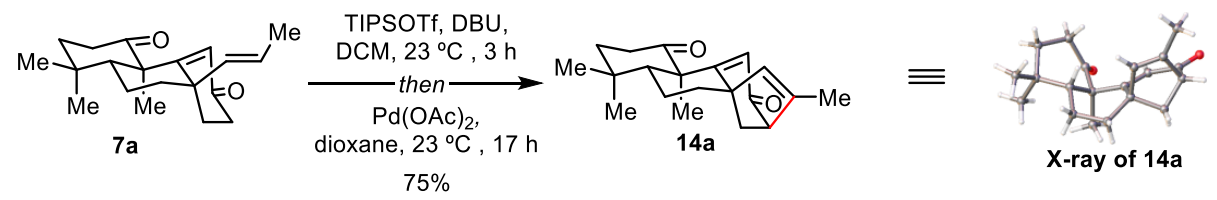

Following the general procedure $B$, enone $7 \mathrm{a}(100 \mathrm{mg}, 0.33 \mathrm{mmol})$ was converted to $14 \mathrm{a}(75 \mathrm{mg}$, $75 \%$ ) in $20 \mathrm{~h}$ as a coloreless solid that was purified by flash chromatography (Petroleum ether/Ethyl acetate $=15 / 1$ to $8 / 1$ ).

Single crystals of $14 \mathrm{a}$ suitable for X-ray crystallographic analysis were obtained by a single recrystallization at $23{ }^{\circ} \mathrm{C}$ using $n$-hexane/ $\mathrm{CHCl}_{3}$ as a solvent by slow evaporation. The relative configuration was determined by X-ray crystallographic analysis. See S115.

Data of 14a: ${ }^{1} \mathrm{H} \mathrm{NMR}\left(400 \mathrm{MHz}, \mathrm{CDCl}_{3}\right) \delta 6.00(\mathrm{~s}, 1 \mathrm{H}), 5.22(\mathrm{~d}, J=1.0 \mathrm{~Hz}, 1 \mathrm{H}), 3.04(\mathrm{~d}, J=3.0 \mathrm{~Hz}$, $1 \mathrm{H}), 2.60-2.50(\mathrm{~m}, 1 \mathrm{H}), 2.37-2.32(\mathrm{~m}, 2 \mathrm{H}), 2.26$ (ddd, $J=14.1,6.4,4.4 \mathrm{~Hz}, 1 \mathrm{H}), 2.03-2.00(\mathrm{~m}, 1 \mathrm{H})$, $1.97-1.93(\mathrm{~m}, 1 \mathrm{H}), 1.92-1.86(\mathrm{~m}, 1 \mathrm{H}), 1.85-1.78(\mathrm{~m}, 2 \mathrm{H}), 1.76(\mathrm{~d}, J=1.2 \mathrm{~Hz}, 3 \mathrm{H}), 1.75-1.67(\mathrm{~m}$, $1 \mathrm{H}), 1.64-1.56(\mathrm{~m}, 1 \mathrm{H}), 1.35(\mathrm{~s}, 3 \mathrm{H}), 1.01(\mathrm{~s}, 3 \mathrm{H}), 0.91(\mathrm{~s}, 3 \mathrm{H})$;

${ }^{13} \mathrm{C}$ NMR $\left(100 \mathrm{MHz}, \mathrm{CDCl}_{3}\right) \delta 212.9,199.9,172.0,143.3,139.5,115.0,61.2,57.4,51.9,50.6,43.7$, $38.4,35.6,32.5,30.6,27.0,24.4,20.1,17.5,15.5$; 
IR (film, cm-1) 2929, 1709, 1672, 1464, 1240;

HRMS(ESI) $[\mathrm{M}+\mathrm{H}]^{+}$calculated for $\mathrm{C}_{20} \mathrm{H}_{27} \mathrm{O}_{2}: 299.2006$, found: 299.2002;

TLC: $R f=0.29$ (Petroleum ether/Ethyl acetate $=10 / 1)$.

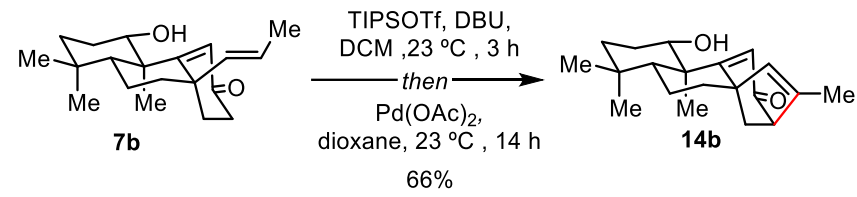

Following the general procedure $B$, enone $7 \mathbf{b}(9 \mathrm{mg}, 0.030 \mathrm{mmol})$ was converted to $14 \mathbf{b}(5.9 \mathrm{mg}$, $66 \%$ ) in $14 \mathrm{~h}$ as a coloreless solid that was purified by flash chromatography (Petroleum ether/Ethyl acetate $=5 / 1$ to $4 / 1$ )

Data of 14b: ${ }^{1} \mathrm{H}$ NMR $\left(500 \mathrm{MHz}, \mathrm{CDCl}_{3}\right) \delta 6.07(\mathrm{~d}, J=1.3 \mathrm{~Hz}, 1 \mathrm{H}), 6.00(\mathrm{~s}, 1 \mathrm{H}), 3.66(\mathrm{dd}, J=10.8$, $5.4 \mathrm{~Hz}, 1 \mathrm{H}), 3.04(\mathrm{~d}, J=3.6 \mathrm{~Hz}, 1 \mathrm{H}), 2.38-2.30(\mathrm{~m}, 2 \mathrm{H}), 1.99-1.81(\mathrm{~m}, 2 \mathrm{H}), 1.77(\mathrm{~d}, J=1.5 \mathrm{~Hz}, 3 \mathrm{H})$, 1.76-1.60 (m, 4H), $1.42(\mathrm{dt}, J=13.4,3.4 \mathrm{~Hz}, 2 \mathrm{H}), 1.29(\mathrm{dd}, J=13.3,4.3 \mathrm{~Hz}, 1 \mathrm{H}), 1.21-1.18(\mathrm{~m}$, $1 \mathrm{H}), 1.16(\mathrm{~s}, 3 \mathrm{H}), 0.95(\mathrm{~s}, 3 \mathrm{H}), 0.88(\mathrm{~s}, 3 \mathrm{H})$;

${ }^{13} \mathrm{C}$ NMR $\left(126 \mathrm{MHz}, \mathrm{CDCl}_{3}\right) \delta$ 201.9, 180.6, 142.6, 139.5, 115.9, 76.7, 61.2, 57.6, 51.2, 44.4, 43.2, $39.6,33.9,31.8,29.4,26.7,21.1,18.4,15.5,15.4$;

IR (film, $\mathrm{cm}^{-1}$ ) 3417, 2946, 2856, 1657, 1457, 1445, 1247, 1096, 1049, 812;

HRMS(ESI) $[\mathrm{M}+\mathrm{H}]^{+}$calculated for $\mathrm{C}_{20} \mathrm{H}_{29} \mathrm{O}_{2}: 301.2162$, found: 301.2160 ;

TLC: $\mathrm{Rf}=0.32($ Petroleum ether/Ethyl acetate $=4 / 1)$.

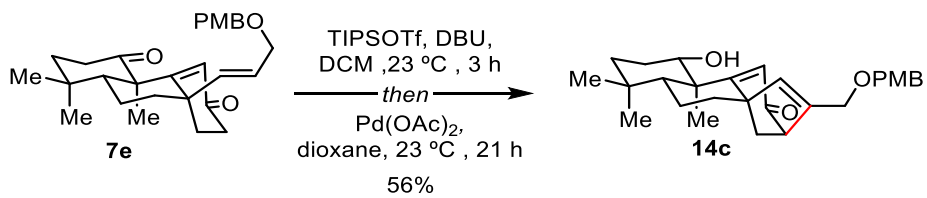

Following the general procedure $B$, enone $7 \mathrm{e}(10 \mathrm{mg}, 0.023 \mathrm{mmol})$ was converted to $14 \mathrm{c}(5.6 \mathrm{mg}$, $56 \%)$ in $24 \mathrm{~h}$ by using 15 equiv. $\mathrm{Pd}(\mathrm{OAc})_{2}(77 \mathrm{mg}, 0.345 \mathrm{mmol})$ as a coloreless oil that was purified by flash chromatography (Petroleum ether/Ethyl acetate $=6 / 1$ to $4 / 1$ ).

Data of 14c: ${ }^{1} \mathrm{H}$ NMR $\left(500 \mathrm{MHz}, \mathrm{CDCl}_{3}\right) \delta 7.24(\mathrm{~d}, J=8.6 \mathrm{~Hz}, 2 \mathrm{H}), 6.88(\mathrm{~d}, J=8.6 \mathrm{~Hz}, 2 \mathrm{H}), 6.30$ (s, 1H), 5.29 (d, J = $1.6 \mathrm{~Hz}, 1 \mathrm{H}), 4.43(\mathrm{~s}, 2 \mathrm{H}), 4.07-3.98(\mathrm{~m}, 2 \mathrm{H}), 3.80(\mathrm{~s}, 3 \mathrm{H}), 3.23(\mathrm{~d}, J=3.8 \mathrm{~Hz}$, $1 \mathrm{H}$ ), 2.54 (ddd, $J=14.2,10.1,8.6 \mathrm{~Hz}, 1 \mathrm{H}), 2.44-2.36(\mathrm{~m}, 2 \mathrm{H}), 2.28$ (ddd, $J=14.2,6.5,4.4 \mathrm{~Hz}, 1 \mathrm{H}$ ), 2.07-1.84 (m, 4H), 1.80 (ddd, $J=13.3,8.6,4.4 \mathrm{~Hz}, 1 \mathrm{H}), 1.77-1.68(\mathrm{~m}, 1 \mathrm{H}), 1.62$ (ddd, $J=13.8$, 10.1, $6.5 \mathrm{~Hz}, 1 \mathrm{H}), 1.37$ (s, 3H), $1.02(\mathrm{~s}, 3 \mathrm{H}), 0.93(\mathrm{~s}, 3 \mathrm{H})$.

${ }^{13} \mathrm{C}$ NMR $\left(126 \mathrm{MHz}, \mathrm{CDCl}_{3}\right) \delta 212.8,199.2,171.5,159.3,144.4,140.5,129.9,129.5,115.5,113.8$, 72.6, 67.0, 57.5, 57.3, 55.3, 51.9, 50.3, 43.8, 38.4, 35.7, 32.5, 30.6, 26.8, 24.4, 20.3, 17.5;

IR (film, $\mathrm{cm}^{-1}$ ) 2958, 2928, 2864, 1711, 1673, 1514, 1445, 1248, 1108, 1076, 1034, 820;

HRMS(ESI) $[\mathrm{M}+\mathrm{H}]^{+}$calculated for $\mathrm{C}_{28} \mathrm{H}_{35} \mathrm{O}_{4}$ : 435.2530, found: 435.2530;

TLC: $\mathrm{Rf}=0.30($ Petroleum ether/Ethyl acetate $=4 / 1)$. 


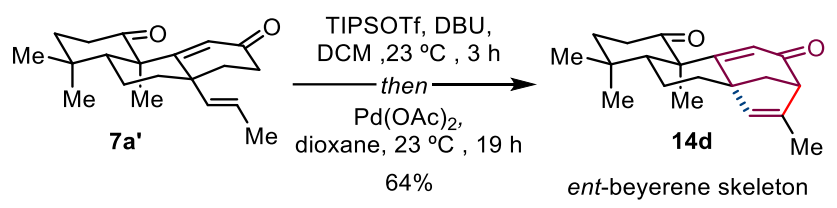

Following the general procedure $B$, enone $7 a^{\prime}$ ( $8 \mathrm{mg}, 0.023 \mathrm{mmol}$ ) was converted to $14 \mathrm{~d}(5.1 \mathrm{mg}$, $64 \%$ ) in $22 \mathrm{~h}$ as a coloreless solid that was purified by flash chromatography (Petroleum ether/Ethyl acetate $=8 / 1$ to $4 / 1$ ).

Data of 14d: ${ }^{1} \mathrm{H}$ NMR $\left(500 \mathrm{MHz}, \mathrm{CDCl}_{3}\right) \delta 6.07(\mathrm{~s}, 1 \mathrm{H}), 5.82(\mathrm{~s}, 1 \mathrm{H}), 3.06-3.03(\mathrm{~m}, 1 \mathrm{H}), 2.59-2.48$ (m, 2H), $2.46(\mathrm{~d}, J=9.9 \mathrm{~Hz}, 1 \mathrm{H}), 2.27(\mathrm{dd}, J=10.0,4.4 \mathrm{~Hz}, 1 \mathrm{H}), 1.98-1.91(\mathrm{~m}, 1 \mathrm{H}), 1.80-1.77(\mathrm{~m}$, $1 \mathrm{H}), 1.76(\mathrm{~d}, \mathrm{~J}=1.5 \mathrm{~Hz}, 4 \mathrm{H}), 1.74-1.67(\mathrm{~m}, 3 \mathrm{H}), 1.58(\mathrm{q}, \mathrm{J}=7.3,6.9 \mathrm{~Hz}, 1 \mathrm{H}), 1.39(\mathrm{~s}, 3 \mathrm{H}), 1.05(\mathrm{~s}$, $3 \mathrm{H}), 1.02(\mathrm{~s}, 3 \mathrm{H})$.

${ }^{13} \mathrm{C}$ NMR $\left(126 \mathrm{MHz}, \mathrm{CDCl}_{3}\right) \delta 212.6,200.2,170.3,142.2,139.9,118.9,60.8,57.11,52.5,50.7$, 49.8, 38.1, 36.9, 35.4, 32.6, 31.3, 24.8, 23.0, 20.1, 15.6;

IR (film, $\mathrm{cm}^{-1}$ ) 2952, 2867, 2864, 1711, 1673, 1514, 1445, 1248, 1108, 1076, 1034, 820;

$\mathrm{HRMS}(E S I)[\mathrm{M}+\mathrm{H}]^{+}$calculated for $\mathrm{C}_{20} \mathrm{H}_{27} \mathrm{O}_{2}: 299.2006$, found: 299.2002;

TLC: $\mathrm{Rf}=0.50($ Petroleum ether $/$ Ethyl acetate $=4 / 1)$. 


\section{Experimental procedures for Scheme 3}

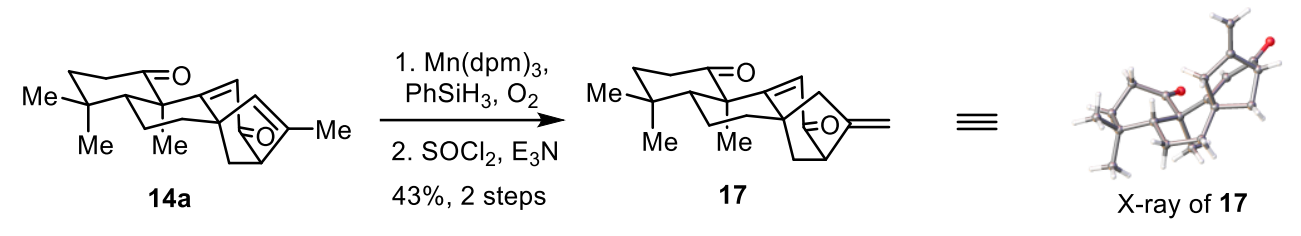

A solution of the $14 \mathrm{a}\left(50 \mathrm{mg}, 0.17 \mathrm{mmol}, 1.0\right.$ equiv.) in $\mathrm{EtOH}(10 \mathrm{~mL})$ was treated with $\mathrm{Mn}(\mathrm{dpm})_{3}$ (20.2 mg, $0.035 \mathrm{mmol}, 20 \mathrm{~mol} \%$ ) and $\mathrm{PhSiH}_{3}\left(46 \mu \mathrm{L}, 0.37 \mathrm{mmol}, 2.17\right.$ equiv.) at $23^{\circ} \mathrm{C}$. The flask was purged three times with oxygen and then closed. After being stirred for $5 \mathrm{~h}$ at this temperature, a solution of triphenyl phosphine $(210 \mathrm{mg}, 0.84 \mathrm{mmol}, 4.94$ equiv.) in dichloromethane $(10 \mathrm{~mL})$ was added at $0{ }^{\circ} \mathrm{C}$. After being stirred overnight, the mixture was was quenched by addition of saturated aqueous $\mathrm{NaHCO}_{3}(20 \mathrm{~mL})$ and the resulting mixture was extracted with ethyl acetate $(3 \times 30 \mathrm{~mL})$. The combined organic phases were washed with brine $(50 \mathrm{~mL})$, dried over $\mathrm{Na}_{2} \mathrm{SO}_{4}$, filterred and concentrated in vacuo. The residue was directly used in next step.

To a stirred solution of aboved residue in $\mathrm{CH}_{2} \mathrm{Cl}_{2}(5 \mathrm{~mL})$ were sequentially added $\mathrm{Et}_{3} \mathrm{~N}(70 \mu \mathrm{L}, 0.51$ mmol, 3.0 equiv. ) and $\mathrm{SOCl}_{2}(20 \mu \mathrm{L}, 0.26 \mathrm{mmol}, 1.5$ equiv. $)$ at $-78{ }^{\circ} \mathrm{C}$. The reaction mixture was stirred at that temperature for $10 \mathrm{~min}$ before the excess reagents were quenched with saturated aq. $\mathrm{NaHCO}_{3}$ solution $(5 \mathrm{~mL})$. The resulting mixture was extracted with $\mathrm{DCM}(3 \times 10 \mathrm{~mL})$. The combined organic phases were washed with brine $(20 \mathrm{~mL})$, dried over $\mathrm{Na}_{2} \mathrm{SO}_{4}$, filtered and concentrated in vacuo. The residue was purified on silica gel chromatography (Petroleum ether/Ethyl acetate $=15 / 1$ to $12 / 1)$ to provide the 17 as white solid (22 $\mathrm{mg}, 43 \%)$ and recover $14 \mathrm{a} 10 \mathrm{mg}(20 \%)$.

Single crystals of 17 suitable for X-ray crystallographic analysis were obtained by a single recrystallization at $23{ }^{\circ} \mathrm{C}$ using $n$-hexane/ $\mathrm{CHCl}_{3}$ as a solvent by slow evaporation. The relative configuration was determined by X-ray crystallographic analysis. See S116.

Data of 17: ${ }^{1} \mathrm{H}$ NMR $\left(400 \mathrm{MHz}, \mathrm{CDCl}_{3}\right) \delta 5.88(\mathrm{~s}, 1 \mathrm{H}), 5.22(\mathrm{~s}, 1 \mathrm{H}), 4.98(\mathrm{~s}, 1 \mathrm{H}), 3.37(\mathrm{~d}, J=4.3 \mathrm{~Hz}$, $1 \mathrm{H}), 2.66-2.56(\mathrm{~m}, 1 \mathrm{H}), 2.53-2.47(\mathrm{~m}, 1 \mathrm{H}), 2.45-2.38(\mathrm{~m}, 2 \mathrm{H}), 2.17-2.12(\mathrm{~m}, 1 \mathrm{H}), 2.07-2.02(\mathrm{~m}, 1 \mathrm{H})$, 1.95-1.90 (m, 2H), 1.84-1.80 (m, 1H), 1.78-1.71 (m, 3H), 1.68-1.61 (m, 1H), $1.41(\mathrm{~s}, 3 \mathrm{H}), 1.01(\mathrm{~s}$, $3 \mathrm{H}), 0.97(\mathrm{~s}, 3 \mathrm{H})$;

${ }^{13} \mathrm{C} \mathrm{NMR}\left(100 \mathrm{MHz}, \mathrm{CDCl}_{3}\right)$ ठ 212.5, 198.8, 170.3, 146.2, 121.6, 111.4, 57.9, 52.6, 48.5, 46.1, 45.3, 43.3, 38.9, 35.9, 32.7, 31.0, 29.2, 24.3, 22.1, 17.7;

IR (film, $\mathrm{cm}^{-1}$ ) 2929, 1709, 1672, 1464, 1240;

HRMS(ESI) $[\mathrm{M}+\mathrm{H}]^{+}$calculated for $\mathrm{C}_{20} \mathrm{H}_{27} \mathrm{O}_{2}: 299.2006$, found: 299.2002;

TLC: $\mathrm{Rf}=0.42($ Petroleum ether/Ethyl acetate $=5 / 1)$. 


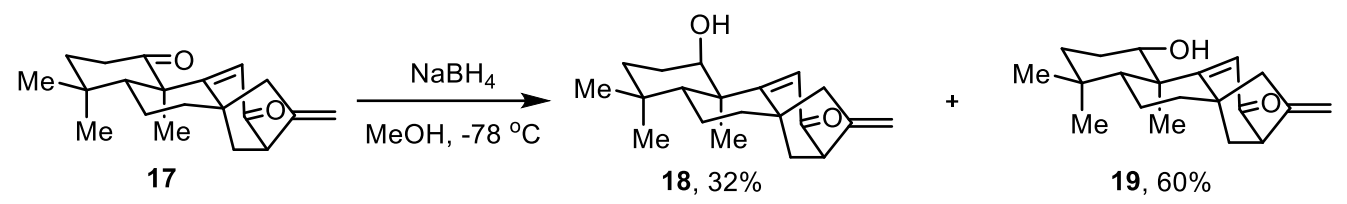

To a solution of 17 (50 mg, 0.168 mmol, 1.0 equiv.) in $\mathrm{MeOH}(5 \mathrm{~mL})$ was added $\mathrm{NaBH}_{4}(6.4 \mathrm{mg}$, $0.168 \mathrm{mmol}, 1.0$ equiv.) at $-78{ }^{\circ} \mathrm{C}$. After stirring for $3 \mathrm{~h}$ at $-78^{\circ} \mathrm{C}$, the excess reagents were quenched with sat. $\mathrm{NaHCO}_{3}(5 \mathrm{~mL})$. The resulting mixture was extracted with $\mathrm{EA}(3 \times 5 \mathrm{~mL})$. The combined organic phases were washed with brine $(5 \mathrm{~mL})$, dried over $\mathrm{Na}_{2} \mathrm{SO}_{4}$, filtered and concentrated in vacuo. The residue was purified on silica gel chromatography (Petroleum ether/Ethyl acetate $=20 / 1)$ to provide the $18(16 \mathrm{mg}, 32 \%)$ and $19(30 \mathrm{mg}, 60 \%)$ as white solid.

Data of 18: ${ }^{1} \mathrm{H}$ NMR $\left(400 \mathrm{MHz}, \mathrm{CDCl}_{3}\right) \delta 5.74(\mathrm{~s}, 1 \mathrm{H}), 5.24(\mathrm{~s}, 1 \mathrm{H}), 5.00(\mathrm{~d}, \mathrm{~J}=13.0 \mathrm{~Hz}, 1 \mathrm{H}), 3.91$ (s, 1H), $3.38(\mathrm{~d}, \mathrm{~J}=4.4 \mathrm{~Hz}, 1 \mathrm{H}), 2.56(\mathrm{~s}, 1 \mathrm{H}), 2.35(\mathrm{dt}, \mathrm{J}=15.9,2.5 \mathrm{~Hz}, 1 \mathrm{H}), 2.02-1.92(\mathrm{~m}, 2 \mathrm{H})$, 1.92-1.85 (m, 3H), 1.84-1.78 (m, 1H), 1.78-1.73 (m, 1H), $1.71(\mathrm{t}, \mathrm{J}=4.5 \mathrm{~Hz}, 2 \mathrm{H}), 1.69-1.63(\mathrm{~m}, 2 \mathrm{H})$, $1.20-1.15(\mathrm{~m}, 4 \mathrm{H}), 0.96(\mathrm{~s}, 3 \mathrm{H}), 0.91(\mathrm{~s}, 3 \mathrm{H})$;

${ }^{13} \mathrm{C}$ NMR $\left(100 \mathrm{MHz}, \mathrm{CDCl}_{3}\right) \delta 200.9,180.5,146.8,121.1,110.8,77.2,58.7,48.5,45.8,45.4,45.3$, 42.8, 39.5, 34.0, 31.9, 30.0, 29.0, 20.9, 18.5, 16.8;

IR (film, cm-1) 3450, 2947, 1677, 1440, 1257, 897;

HRMS(ESI) $[\mathrm{M}+\mathrm{H}]^{+}$calculated for $\mathrm{C}_{20} \mathrm{H}_{29} \mathrm{O}_{2}: 301.2162$, found: 301.2162 ;

TLC: $\mathrm{Rf}=0.61($ Petroleum ether/Ethyl acetate $=2 / 1)$.

Data of 19: ${ }^{1} \mathrm{H}$ NMR $\left(400 \mathrm{MHz}, \mathrm{CDCl}_{3}\right) \delta 6.71(\mathrm{~s}, 1 \mathrm{H}), 5.24(\mathrm{~s}, 1 \mathrm{H}), 4.96(\mathrm{~s}, 1 \mathrm{H}), 3.66$ (dd, $J=10.7$, $5.6 \mathrm{~Hz}, 1 \mathrm{H}), 3.38(\mathrm{~d}, J=4.5 \mathrm{~Hz}, 1 \mathrm{H}), 2.56(\mathrm{~d}, J=15.6 \mathrm{~Hz}, 1 \mathrm{H}), 2.39(\mathrm{dt}, J=16.0,2.5 \mathrm{~Hz}, 1 \mathrm{H}), 2.08-$ $2.01(\mathrm{~m}, 1 \mathrm{H}), 1.93(\mathrm{dd}, J=11.0,2.3 \mathrm{~Hz}, 1 \mathrm{H}), 1.91-1.84(\mathrm{~m}, 1 \mathrm{H}), 1.76(\mathrm{dd}, J=11.0,4.7 \mathrm{~Hz}, 1 \mathrm{H})$, 1.74-1.69 (m, 1H), 1.69-1.62 (m, 2H), 1.61-1.57 (m, 2H), $1.42(\mathrm{dt}, J=13.5,3.5 \mathrm{~Hz}, 1 \mathrm{H}), 1.35$ (dd, $J=11.4,8.2 \mathrm{~Hz}, 1 \mathrm{H}), 1.30-1.27(\mathrm{~m}, 1 \mathrm{H}), 1.21(\mathrm{~s}, 3 \mathrm{H}), 0.95(\mathrm{~s}, 3 \mathrm{H}), 0.87(\mathrm{~s}, 3 \mathrm{H})$;

${ }^{13} \mathrm{C} \mathrm{NMR}\left(100 \mathrm{MHz}, \mathrm{CDCl}_{3}\right) \delta$ 199.4, 179.2, 146.5, 119.2, 111.8, 71.1, 57.3, 48.3, 46.1, 45.5, 43.3, $36.6,34.3,34.1,32.5,28.4,24.0,23.2,21.4$;

IR (film, $\mathrm{cm}^{-1}$ ) 3459, 2941, 1656, 1458, 1250, 1044, 888;

HRMS(ESI) $[\mathrm{M}+\mathrm{H}]^{+}$calculated for $\mathrm{C}_{20} \mathrm{H}_{29} \mathrm{O}_{2}: 301.2162$, found: 301.2162 ;

TLC: $\mathrm{Rf}=0.32($ Petroleum ether/Ethyl acetate $=2 / 1)$.

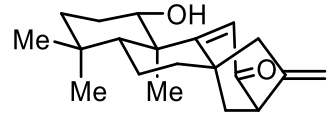

19

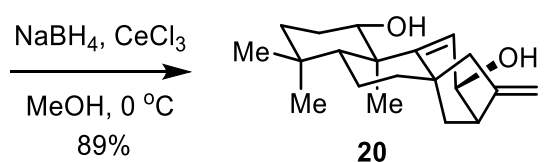

20

To a solution of 19 (9.5 mg, $0.0317 \mathrm{mmol}, 1.0$ equiv.) in $\mathrm{MeOH}(2 \mathrm{~mL})$ was added $\mathrm{CeCl}_{3} \cdot 7 \mathrm{H}_{2} \mathrm{O}(13$ $\mathrm{mg}, 0.0349 \mathrm{mmol}, 1.1$ equiv.) at $23^{\circ} \mathrm{C}$. After stirring at this temperature for $15 \mathrm{~min}$, the reaction was colled to $0{ }^{\circ} \mathrm{C}$ and $\mathrm{NaBH}_{4}\left(1.2 \mathrm{mg}, 0.0317 \mathrm{mmol}, 1.0\right.$ equiv.) was added. After stirring at $0{ }^{\circ} \mathrm{C}$ for 1 $h$, the excess reagents were quenched by addition of saturated aqueous $\mathrm{NaHCO}_{3}(5 \mathrm{~mL})$ and the 
resulting mixture was extracted with ethyl acetate $(3 \times 5 \mathrm{~mL})$. The combined organic phases were washed with brine $(5 \mathrm{~mL})$, dried over $\mathrm{Na}_{2} \mathrm{SO}_{4}$, filterred and concentrated in vacuo. The residue was purified on silica gel chromatography (Petroleum ether/Ethyl acetate $=10 / 1$ ) to provide alcohol 20 as colorless oil ( $8.5 \mathrm{mg}, 89 \%)$.

Data of ketone 20: ${ }^{1} \mathrm{H}$ NMR (400 MHz, $\left.\mathrm{CDCl}_{3}\right) \delta 6.09$ (s, 1H), 5.05 (s, 1H), 5.00 (s, 1H), 4.39 (dd, $J=5.3,2.7 \mathrm{~Hz}, 1 \mathrm{H}), 3.68-3.58(\mathrm{~m}, 1 \mathrm{H}), 2.76(\mathrm{t}, J=5.4 \mathrm{~Hz}, 1 \mathrm{H}), 2.51(\mathrm{~d}, J=16.0 \mathrm{~Hz}, 1 \mathrm{H}), 2.26$ (dt, $J=16.1,2.6 \mathrm{~Hz}, 1 \mathrm{H}), 1.95-1.86(\mathrm{~m}, 1 \mathrm{H}), 1.83-1.72(\mathrm{~m}, 2 \mathrm{H}), 1.71-1.67(\mathrm{~m}, 1 \mathrm{H}), 1.64-1.62(\mathrm{~m}, 1 \mathrm{H})$, 1.60-1.57 (m, 2H), 1.47-1.44 (m, 1H), 1.41-1.35 (m, 1H), 1.34-1.27 (m, 2H), $1.10(\mathrm{~s}, 3 \mathrm{H}), 0.90(\mathrm{~s}$, $3 \mathrm{H}), 0.83(\mathrm{~s}, 3 \mathrm{H})$;

${ }^{13} \mathrm{C}$ NMR $\left(100 \mathrm{MHz}, \mathrm{CDCl}_{3}\right) \delta 157.6,151.3,120.0,109.1,78.3,70.6,50.4,48.5,46.1,43.9,43.7$, 43.3, 39.8, 33.6, 32.0, 29.9, 29.4, 20.8, 18.8, 17.6;

IR (film, cm-1) 3399, 2936, 1458, 1387, 1029, 911, 734;

HRMS(ESI) [M + Na] $]^{+}$calculated for $\mathrm{C}_{20} \mathrm{H}_{30} \mathrm{NaO}_{2}: 325.2138$, found: 325.2137;

TLC: $\mathrm{Rf}=0.31($ Petroleum ether/Ethyl acetate $=2 / 1)$.

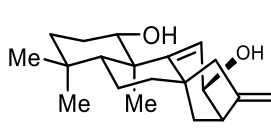

20

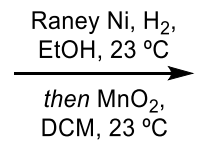

DCM, $23^{\circ} \mathrm{C}$

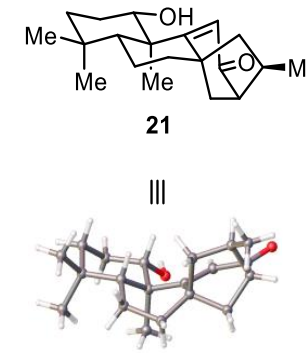

X-ray of 21

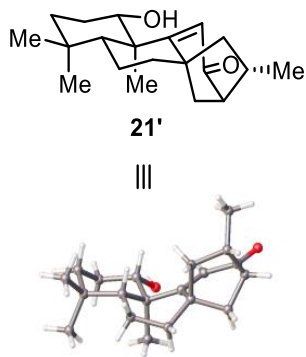

X-ray of $21^{\prime}$

To a solution of 20 (24 mg, $0.079 \mathrm{mmol}, 1.0$ equiv.) in $\mathrm{EtOH}(15 \mathrm{~mL})$ was added raney nickel at 23 ${ }^{\circ} \mathrm{C}$. This suspension was degassed at $-78{ }^{\circ} \mathrm{C}$ and backfilled with $\mathrm{H}_{2}$ three times. After $12 \mathrm{~h}$, the reaction was concentrated in vacuo. The residue was redissolved in $\mathrm{DCM}$ and $\mathrm{MnO}_{2}$ (69 mg, 0.79 mmol, 10.0 equiv.) was added. After stirred at $23^{\circ} \mathrm{C}$ for $2 \mathrm{~h}$, the reaction mixture was filtered through Celite ${ }^{\circledR}$, concentrated in vacuo and purified on prepared TLC silica gel (Dichloromethane / Ethyl acetate $=5 / 1)$ to afford $21(18 \mathrm{mg}, 75 \%)$ and $\mathbf{2 1}{ }^{\prime}(3 \mathrm{mg}, 13 \%)$.

Single crystals of $\mathbf{2 1}$ and 21' suitable for X-ray crystallographic analysis were obtained by a single recrystallization at $23{ }^{\circ} \mathrm{C}$ using $n$-hexane/ $\mathrm{CH}_{2} \mathrm{Cl}_{2}$ as a solvent by slow evaporation. The relative configuration was determined by X-ray crystallographic analysis. See S117-S118.

Data of 21: ${ }^{1} \mathrm{H}$ NMR $\left(400 \mathrm{MHz}, \mathrm{CDCl}_{3}\right) \delta 6.71(\mathrm{~d}, \mathrm{~J}=0.9 \mathrm{~Hz}, 1 \mathrm{H}), 3.68-3.63(\mathrm{~m}, 1 \mathrm{H}), 2.48-2.43(\mathrm{~m}$, $1 \mathrm{H}), 2.25-2.18(\mathrm{~m}, 1 \mathrm{H}), 2.07-2.00(\mathrm{~m}, 2 \mathrm{H}), 1.91-1.87(\mathrm{~m}, 1 \mathrm{H}), 1.86-1.81(\mathrm{~m}, 1 \mathrm{H}), 1.73-1.72(\mathrm{~m}, 2 \mathrm{H})$, 1.71-1.63 (m, 3H), $1.52(\mathrm{dd}, J=13.7,9.3 \mathrm{~Hz}, 1 \mathrm{H}), 1.41$ (dt, $J=13.5,3.4 \mathrm{~Hz}, 1 \mathrm{H}), 1.35$ (dd, $J=11.3$, $8.3 \mathrm{~Hz}, 1 \mathrm{H}), 1.28-1.25(\mathrm{~m}, 1 \mathrm{H}), 1.22(\mathrm{dd}, J=12.3,5.7 \mathrm{~Hz}, 1 \mathrm{H}), 1.18(\mathrm{~s}, 3 \mathrm{H}), 1.14$ (d, $J=7.0 \mathrm{~Hz}$, $3 \mathrm{H}), 0.94(\mathrm{~s}, 3 \mathrm{H}), 0.84(\mathrm{~s}, 3 \mathrm{H})$; 
${ }^{13} \mathrm{C}$ NMR $\left(100 \mathrm{MHz}, \mathrm{CDCl}_{3}\right)$ б 205.7, 182.3, 121.0, 57.7, 48.4, 47.3, 45.5, 45.4, 42.6, 39.6, 34.7, $33.9,31.9,29.8,29.7,29.3,22.4,20.9,18.7,16.6$;

IR (film, cm-1) 3408, 2948, 1650, 1460, 1248, 1045, 866;

HRMS(ESI) $[\mathrm{M}+\mathrm{H}]^{+}$calculated for $\mathrm{C}_{20} \mathrm{H}_{31} \mathrm{O}: 303.2318$, found: 303.2312;

TLC: $R f=0.35($ Petroleum ether/Ethyl acetate $=3 / 1)$.

Data of 21': ${ }^{1} \mathrm{H}$ NMR (400 MHz, $\left.\mathrm{CDCl}_{3}\right) \delta 6.70(\mathrm{~s}, 1 \mathrm{H}), 3.66$ (dd, $\left.J=10.3,5.9 \mathrm{~Hz}, 1 \mathrm{H}\right), 2.83-2.75$ (m, 1H), 2.58-2.50 (m, 1H), $2.04(\mathrm{dd}, J=12.6,10.5 \mathrm{~Hz}, 1 \mathrm{H}), 2.01-1.92(\mathrm{~m}, 1 \mathrm{H}), 1.89-1.81(\mathrm{~m}, 2 \mathrm{H})$, $1.75-1.68(\mathrm{~m}, 1 \mathrm{H}), 1.66-1.60(\mathrm{~m}, 3 \mathrm{H}), 1.53-1.46(\mathrm{~m}, 1 \mathrm{H}), 1.45-1.38(\mathrm{~m}, 3 \mathrm{H}), 1.37-1.27(\mathrm{~m}, 2 \mathrm{H})$, $1.17(\mathrm{~s}, 3 \mathrm{H}), 0.95(\mathrm{~s}, 3 \mathrm{H}), 0.92(\mathrm{~d}, J=7.2 \mathrm{~Hz}, 3 \mathrm{H}), 0.86(\mathrm{~s}, 3 \mathrm{H})$;

${ }^{13} \mathrm{C}$ NMR $\left(100 \mathrm{MHz}, \mathrm{CDCl}_{3}\right)$ б 204.8, 184.4, 122.5, 77.4, 56.3, 49.1, 46.7, 46.3, 45.4, 42.7, 39.6, $34.2,34.0,31.89,29.8,29.5,21.0,18.8,18.6,16.4$;

IR (film, cm-1) 3394, 2927, 1650, 1460, 1265, 1034, 734;

HRMS(ESI) $[\mathrm{M}+\mathrm{H}]^{+}$calculated for $\mathrm{C}_{20} \mathrm{H}_{31} \mathrm{O}: 303.2318$, found: 303.2315 ;

TLC: $\mathrm{Rf}=0.38($ Petroleum ether/Ethyl acetate $=3 / 1)$.

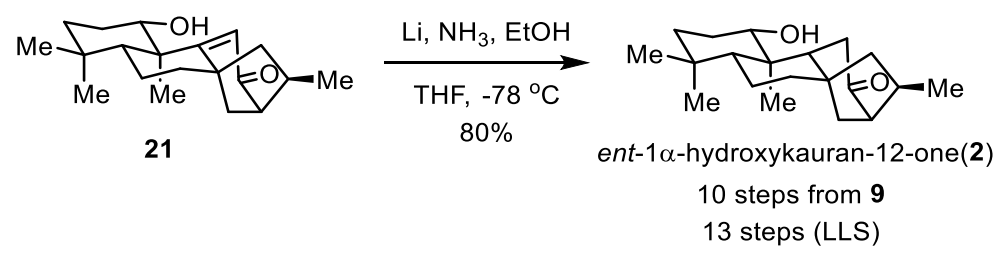

To a solution of 21 (5 mg, 0.0166 mmol, 1.0 equiv.) in THF ( $3 \mathrm{~mL}$ ) and liquid $\mathrm{NH}_{3}(5 \mathrm{~mL})$ was added $\mathrm{EtOH}$ (75 ul, 77 equiv.) and sodium (100 mg, 262 equiv.) at $-78^{\circ} \mathrm{C}$ to keep the solution in dark blue. The reaction mixture was stirred at $-78{ }^{\circ} \mathrm{C}$ for additional $10 \mathrm{~min}$ before the excess reagents were quenched by adding solid $\mathrm{NH}_{4} \mathrm{Cl}$ at $-78{ }^{\circ} \mathrm{C}$ and then warmed to $23^{\circ} \mathrm{C}$ slowly. The aqueous layer was extracted with EA ( $5 \mathrm{~mL} \times 3)$, and the combined organic extracts were dried over anhydrous $\mathrm{Na}_{2} \mathrm{SO}_{4}$ and concentrated in vacuo. The residue was purified by flash chromatography on silica gel (Petroleum ether/Ethyl acetate $=6 / 1)$ to afford $2(4 \mathrm{mg}, 80 \%)$ as a light-yellow oil.

Data of ent-1 $\alpha$-hydroxykauran-12-one (2): ${ }^{1} \mathrm{H}$ NMR $\left(500 \mathrm{MHz}, \mathrm{CDCl}_{3}\right) \delta 3.65(\mathrm{~d}, J=17.0 \mathrm{~Hz}, 1 \mathrm{H})$, 3.28 (dd, $J=10.8,4.2 \mathrm{~Hz}, 1 \mathrm{H}$ ), 2.48 (dd, $J=17.1,9.5 \mathrm{~Hz}, 1 \mathrm{H}$ ), 2.31 (d, $J=4.6 \mathrm{~Hz}, 1 \mathrm{H}), 2.25$ (d, $J$ $=12.3 \mathrm{~Hz}, 1 \mathrm{H}), 2.17-2.11(\mathrm{~m}, 1 \mathrm{H}), 1.99(\mathrm{dd}, J=13.6,1.7 \mathrm{~Hz}, 1 \mathrm{H}), 1.69(\mathrm{~d}, J=9.7 \mathrm{~Hz}, 1 \mathrm{H}), 1.65-$ $1.62(\mathrm{~m}, 1 \mathrm{H}), 1.61-1.62(\mathrm{~m}, 2 \mathrm{H}), 1.56-1.54(\mathrm{~m}, 1 \mathrm{H}), 1.51-1.48(\mathrm{~m}, 1 \mathrm{H}), 1 . .39-1.37(\mathrm{~m}, 1 \mathrm{H}), 1.36-$ $1.34(\mathrm{~m}, 1 \mathrm{H}), 1.27-1.30(\mathrm{~m}, 1 \mathrm{H}), 1.18(\mathrm{dd}, J=13.6,4.7 \mathrm{~Hz}, 1 \mathrm{H}), 1.00(\mathrm{~d}, J=7.0 \mathrm{~Hz}, 3 \mathrm{H}), 0.93(\mathrm{~s}$, $3 \mathrm{H}), 0.85(\mathrm{~s}, 3 \mathrm{H}), 0.78(\mathrm{~s}, 3 \mathrm{H}), 0.73(\mathrm{dd}, J=11.9,1.5 \mathrm{~Hz}, 1 \mathrm{H})$;

${ }^{13} \mathrm{C} \mathrm{NMR}\left(125 \mathrm{MHz}, \mathrm{CDCl}_{3}\right) \delta 216.8,82.0,59.7,57.8,54.3,50.3,46.0,44.6,40.1,39.8,37.5$, 36.9 35.2, 33.2, 33.0, 29.9, 22.9, 21.2, 20.5, 12.6;

IR (film, cm-1) 2923, 1727, 1460, 1054, 511, 469;

HRMS(ESI) $[\mathrm{M}+\mathrm{H}]^{+}$calculated for $\mathrm{C}_{20} \mathrm{H}_{33} \mathrm{O}_{2}: 305.2475$, found: 305.2474 ; 
TLC: $\mathrm{Rf}=0.32($ Petroleum ether/Ethyl acetate $=2 / 1)$.

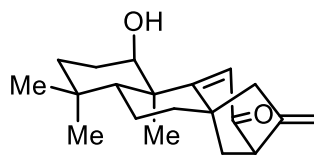

$18,32 \%$

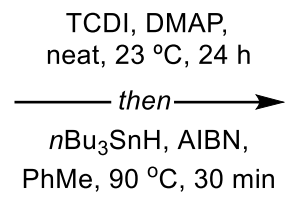

$72 \%$

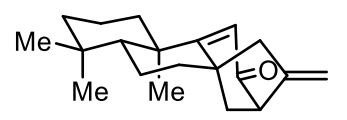

12-oxo-9,11-dehydrokaurene( 22 )

8 steps from 9

11 steps (LLS)

A solution of the alcohol 18 ( $15 \mathrm{mg}, 0.05 \mathrm{mmol}, 1.0$ equiv.), TCDI ( $36 \mathrm{mg}, 0.2 \mathrm{mmol}, 4.0$ equiv.) and DMAP (27.5 mg, $0.225 \mathrm{mmol}, 4.5$ equiv.) in DCM (1 mL) was concentrated in vacuo. The resulted mixture was stirred at $23^{\circ} \mathrm{C}$ for $24 \mathrm{~h}$ under $\mathrm{Ar}$ atmosphere. Then the mixture was redissolved in toluene, AIBN (0.8 g, $0.005 \mathrm{mmol}, 0.1$ equiv.) and $\mathrm{nBu} 3 \mathrm{SnH}$ (67 ul, $0.25 \mathrm{mmol}, 5.0$ equiv.) were added sequentially. After stirring for $30 \mathrm{~min}$ at $90^{\circ} \mathrm{C}$, the solution was cooled to $23^{\circ} \mathrm{C}$ and purified by flash chromatography (Petroleum ether/Ethyl acetate $=10 / 1$ ) to afford 12-oxo-9,11dehydrokaurene 22 as an oil (10.2 $\mathrm{mg}, 72 \%)$.

Data of 12-oxo-9,11-dehydrokaurene 22: ${ }^{1} \mathrm{H}$ NMR (400 MHz, $\left.\mathrm{CDCl}_{3}\right) \delta 5.69(\mathrm{~s}, 1 \mathrm{H}), 5.23(\mathrm{~s}, 1 \mathrm{H})$, $4.97(\mathrm{~s}, 1 \mathrm{H}), 3.38(\mathrm{~d}, J=4.6 \mathrm{~Hz}, 1 \mathrm{H}), 2.57(\mathrm{~d}, J=15.1 \mathrm{~Hz}, 1 \mathrm{H}), 2.37(\mathrm{dt}, J=16.0,2.6 \mathrm{~Hz}, 1 \mathrm{H})$, 2.08-2.00 (m, , 1H), 1.93-1.85 (m, 3H), $1.78(\mathrm{dd}, J=11.1,4.7 \mathrm{~Hz}, 1 \mathrm{H}), 1.73-1.69(\mathrm{~m}, 1 \mathrm{H}), 1.64-$ $1.59(\mathrm{~m}, 2 \mathrm{H}), 1.55-1.49(\mathrm{~m}, 1 \mathrm{H}), 1.43(\mathrm{dd}, J=13.1,1.6 \mathrm{~Hz}, 1 \mathrm{H}), 1.37(\mathrm{dd}, J=11.6,8.2 \mathrm{~Hz}, 1 \mathrm{H})$, $1.25-1.20(\mathrm{~m}, 1 \mathrm{H}), 1.17(\mathrm{~s}, 3 \mathrm{H}), 1.11(\mathrm{td}, J=13.4,3.8 \mathrm{~Hz}, 1 \mathrm{H}), 0.96(\mathrm{~s}, 3 \mathrm{H}), 0.88(\mathrm{~s}, 3 \mathrm{H})$;

${ }^{13} \mathrm{C}$ NMR $\left(100 \mathrm{MHz}, \mathrm{CDCl}_{3}\right) \delta 200.3,182.9,146.9,118.9,110.9,58.3,48.6,45.5,44.7,43.3,41.8$, $39.9,39.2,34.2,32.6,28.7,23.3,21.4,18.8,18.1$;

IR (film, cm-1) 2942, 2866, 1680, 1457, 1247, 1036, 921;

HRMS(ESI) $\left[\mathrm{M}+\mathrm{H}^{+}\right.$calculated for $\mathrm{C}_{20} \mathrm{H}_{29} \mathrm{O}: 285.2213$, found: 285.2212;

TLC: $\mathrm{Rf}=0.75($ Petroleum ether/Ethyl acetate $=4 / 1)$.

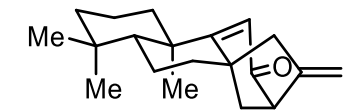

12-oxo-9,11-dehydrokaurene

22

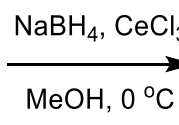

$88 \%$

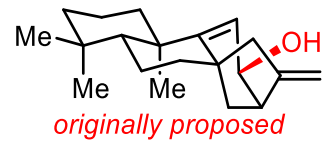

$12 \beta$-hydroxy-9,11dehydrokaurene (23)

To a solution of dienone 12-oxo-9,11-dehydrokaurene 22 (10.2 mg, $0.0359 \mathrm{mmol}, 1.0$ equiv.) in $\mathrm{MeOH}(2 \mathrm{~mL})$ was added $\mathrm{CeCl}_{3} \cdot 7 \mathrm{H}_{2} \mathrm{O}(14.7 \mathrm{mg}, 0.0395 \mathrm{mmol}, 1.1$ equiv. $)$ at $23^{\circ} \mathrm{C}$. After stirring at this temperature for $15 \mathrm{~min}$, the reaction was colling to $0^{\circ} \mathrm{C}$ and $\mathrm{NaBH}_{4}(1.4 \mathrm{mg}, 0.0359 \mathrm{mmol}, 1.0$ equiv.) was added. After stirring at $0{ }^{\circ} \mathrm{C}$ for $1 \mathrm{~h}$, the excess reagents were quenched by addition of saturated aqueous $\mathrm{NaHCO}_{3}(5 \mathrm{~mL})$ and the resulting mixture was extracted with ethyl acetate $(3 \times$ $5 \mathrm{~mL})$. The combined organic phases were washed with brine $(5 \mathrm{~mL})$, dried over $\mathrm{Na}_{2} \mathrm{SO}_{4}$, filterred and concentrated in vacuo. The residue was purified on silica gel chromatography (Petroleum ether/Ethyl acetate $=10 / 1)$ to provide alcohol 23 as colorless oil $(9 \mathrm{mg}, 88 \%)$. 
Data of 23: ${ }^{1} \mathrm{H}$ NMR $\left(400 \mathrm{MHz}, \mathrm{CDCl}_{3}\right) \delta 5.14(\mathrm{~s}, 1 \mathrm{H}), 5.05(\mathrm{~d}, J=1.2 \mathrm{~Hz}, 1 \mathrm{H}), 5.01(\mathrm{~s}, 1 \mathrm{H}), 4.35$ (ddd, $J=11.9,5.4,2.5 \mathrm{~Hz}, 1 \mathrm{H}), 2.76(\mathrm{t}, J=5.3 \mathrm{~Hz}, 1 \mathrm{H}), 2.49$ (d, $J=16.8 \mathrm{~Hz}, 1 \mathrm{H}), 2.24(\mathrm{dt}, J=16.0$, $2.6 \mathrm{~Hz}, 1 \mathrm{H}), 1.95-1.83(\mathrm{~m}, 3 \mathrm{H}), 1.83-1.73(\mathrm{~m}, 1 \mathrm{H}), 1.70(\mathrm{dd}, J=10.9,5.5 \mathrm{~Hz}, 1 \mathrm{H}), 1.60-1.55$ $(\mathrm{m}, 4 \mathrm{H}), 1.52-1.48(\mathrm{~m}, 1 \mathrm{H}), 1.47-1.43(\mathrm{~m}, 1 \mathrm{H}), 1.41-1.37(\mathrm{~m}, 1 \mathrm{H}), 1.31(\mathrm{dd}, J=11.7,8.1 \mathrm{~Hz}, 2 \mathrm{H})$, 1.16-1.07 (m, 2H), $1.06(\mathrm{~s}, 3 \mathrm{H}), 0.91(\mathrm{~s}, 3 \mathrm{H}), 0.84(\mathrm{~s}, 3 \mathrm{H})$;

${ }^{13} \mathrm{C}$ NMR $\left(100 \mathrm{MHz}, \mathrm{CDCl}_{3}\right) \delta 159.5,151.5,117.5,109.2,70.9,50.0,48.3,46.3,44.2,42.9,42.2$, $39.9,38.2,33.9,32.7,29.1,24.3,21.3,19.1,18.2$;

IR (film, cm-1) 3457, 2927, 2846, 1680, 1457, 11375, 1045, 887;

HRMS(ESI) $\left[\mathrm{M}-\mathrm{H}_{2} \mathrm{O}+\mathrm{H}\right]^{+}$calculated for $\mathrm{C}_{20} \mathrm{H}_{28}: 269.2269$, found: 269.2264;

TLC: $\mathrm{Rf}=0.76($ Petroleum ether/Ethyl acetate $=4 / 1)$.

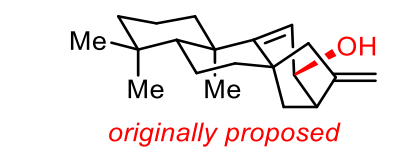

$12 \beta$-hydroxy-9,11-dehydrokaurene

(23)

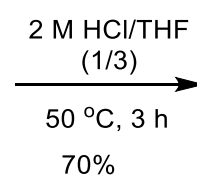

12.

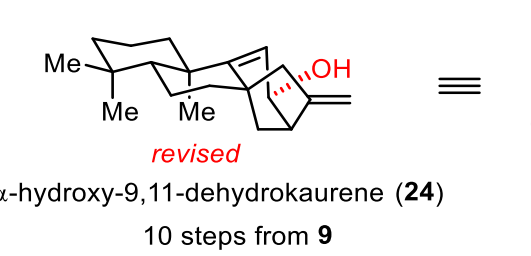

13 steps (LLS)

Alcohol 23 (9 mg, $0.031 \mathrm{mmol}, 1.0$ equiv.) was dissolved in THF/2 M HCl (1.0 mL/0.33 mL) and stirred at $50{ }^{\circ} \mathrm{C}$ for $3 \mathrm{~h}$. Then reaction mixture was cooling to $23^{\circ} \mathrm{C}$ and the excess reagents were quenched with saturated aqueous $\mathrm{NaHCO}_{3}(30 \mathrm{~mL})$, the resulting mixture was extracted with ethyl acetate $(3 \times 5 \mathrm{~mL})$. The combined organic phases were washed with brine $(5 \mathrm{~mL})$, dried over $\mathrm{Na}_{2} \mathrm{SO}_{4}$, filterred and concentrated in vacuo. The residue was purified on silica gel chromatography (Petroleum ether/Ethyl acetate $=10 / 1)$ to provide alcohol 24 as colorless solid $(6.3 \mathrm{mg}, 70 \%)$ and recover $23(1.3 \mathrm{mg})$.

Single crystals of $\mathbf{2 4}$ suitable for X-ray crystallographic analysis were obtained by a single recrystallization at $23{ }^{\circ} \mathrm{C}$ using $n$-hexane/MeOH as a solvent by slow evaporation. The relative configuration was determined by X-ray crystallographic analysis. See S119.

Data of 24: ${ }^{1} \mathrm{H}$ NMR $\left(400 \mathrm{MHz}, \mathrm{CDCl}_{3}\right) \delta 5.28(\mathrm{~d}, J=4.0 \mathrm{~Hz}, 1 \mathrm{H}), 5.04(\mathrm{~d}, J=1.1 \mathrm{~Hz}, 1 \mathrm{H}), 4.90$ (s, $1 \mathrm{H}), 3.94(\mathrm{t}, J=3.4 \mathrm{~Hz}, 1 \mathrm{H}), 2.83(\mathrm{~s}, 1 \mathrm{H}), 2.46(\mathrm{~d}, J=15.8 \mathrm{~Hz}, 1 \mathrm{H}), 2.11(\mathrm{dt}, J=15.6,2.6 \mathrm{~Hz}, 1 \mathrm{H})$, 2.01-1.92 (m, 1H), 1.90-1.85 (m, 1H), 1.84-1.73 (m, 1H), 1.62-1.54 (m, 3H), 1.53-1.48 (m, 2H), 1.46-1.39 (m, 2H), 1.39-1.32 (m, 1H), 1.20-1.14 (m, 1H), 1.12-1.06 (M, 1H), $1.10(\mathrm{~s}, 3 \mathrm{H}), 0.92(\mathrm{~s}$, $3 \mathrm{H}), 0.84(\mathrm{~s}, 3 \mathrm{H})$;

${ }^{13} \mathrm{C}$ NMR $\left(100 \mathrm{MHz}, \mathrm{CDCl}_{3}\right) \delta 162.2,152.6,115.8,108.2,72.7,48.6,47.1,43.9,43.5,42.1,40.3$, 40.0, 38.5, 34.0, 32.7, 28.9, 24.4, 21.4, 19.1, 18.1;

IR (film, cm-1) 3351, 2927, 2864, 1459, 1374, 1259, 1020, 879;

HRMS(ESI) $\left[\mathrm{M}-\mathrm{H}_{2} \mathrm{O}+\mathrm{H}\right]^{+}$calculated for $\mathrm{C}_{20} \mathrm{H}_{29}$ : 269.2269, found: 269.2262;

TLC: $\mathrm{Rf}=0.4$ (Petroleum ether/Ethyl acetate $=4 / 1)$. 


\section{NMR spectra}

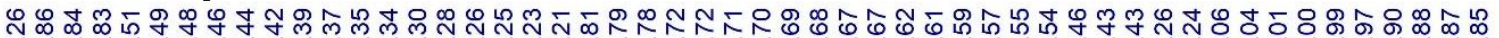

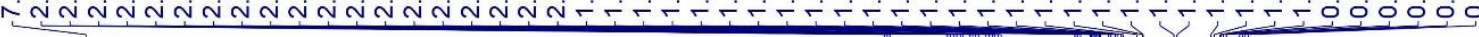

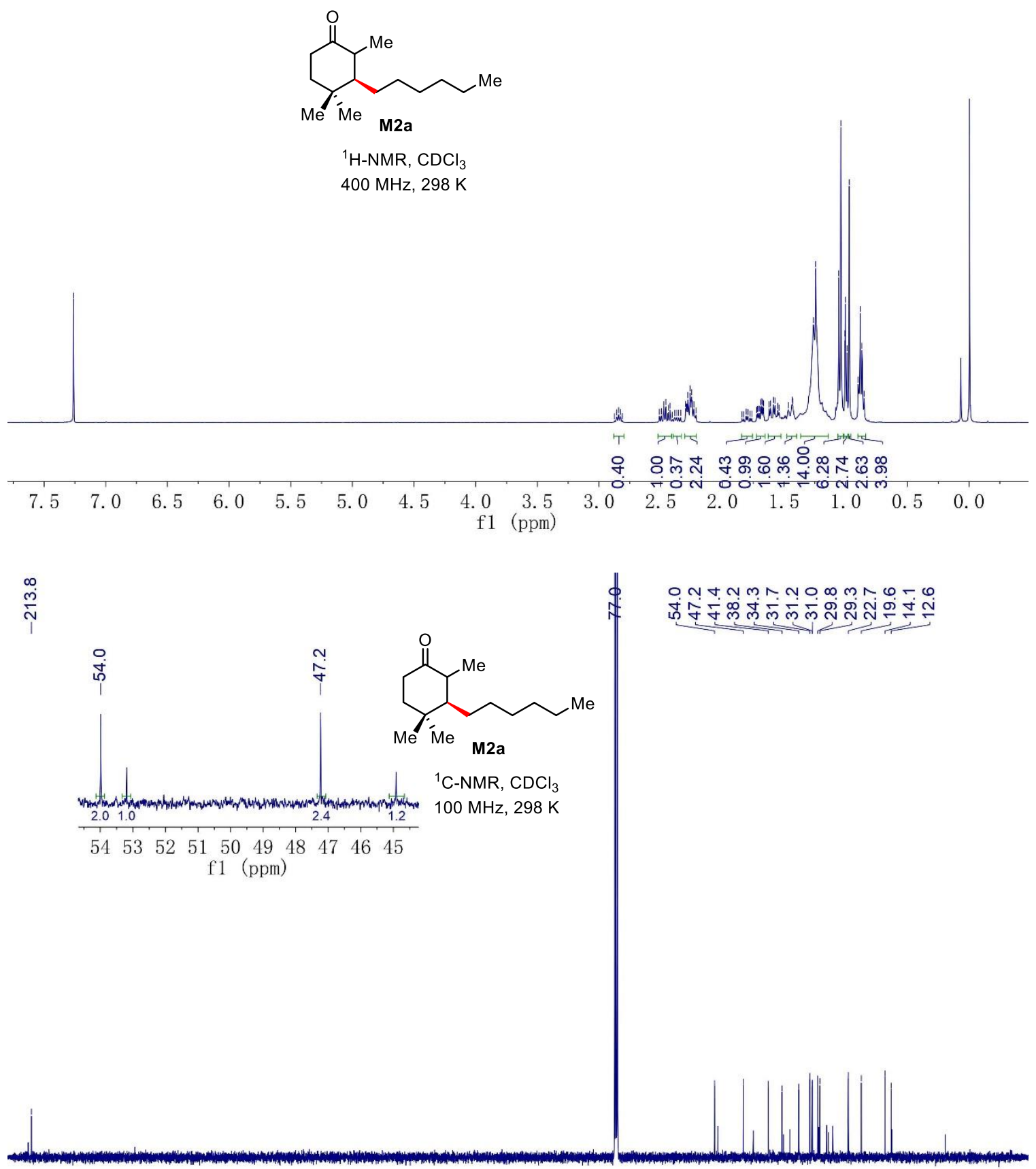

$\begin{array}{lllllllllllllllllllllll}210 & 200 & 190 & 180 & 170 & 160 & 150 & 140 & 130 & 120 & 110 & 100 & 90 & 80 & 70 & 60 & 50 & 40 & 30 & 20 & 10 & 0 & -10\end{array}$ f1 (ppm) 


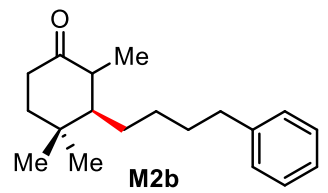

${ }^{1} \mathrm{H}-\mathrm{NMR}, \mathrm{CDCl}_{3}$ $400 \mathrm{MHz}, 298 \mathrm{~K}$
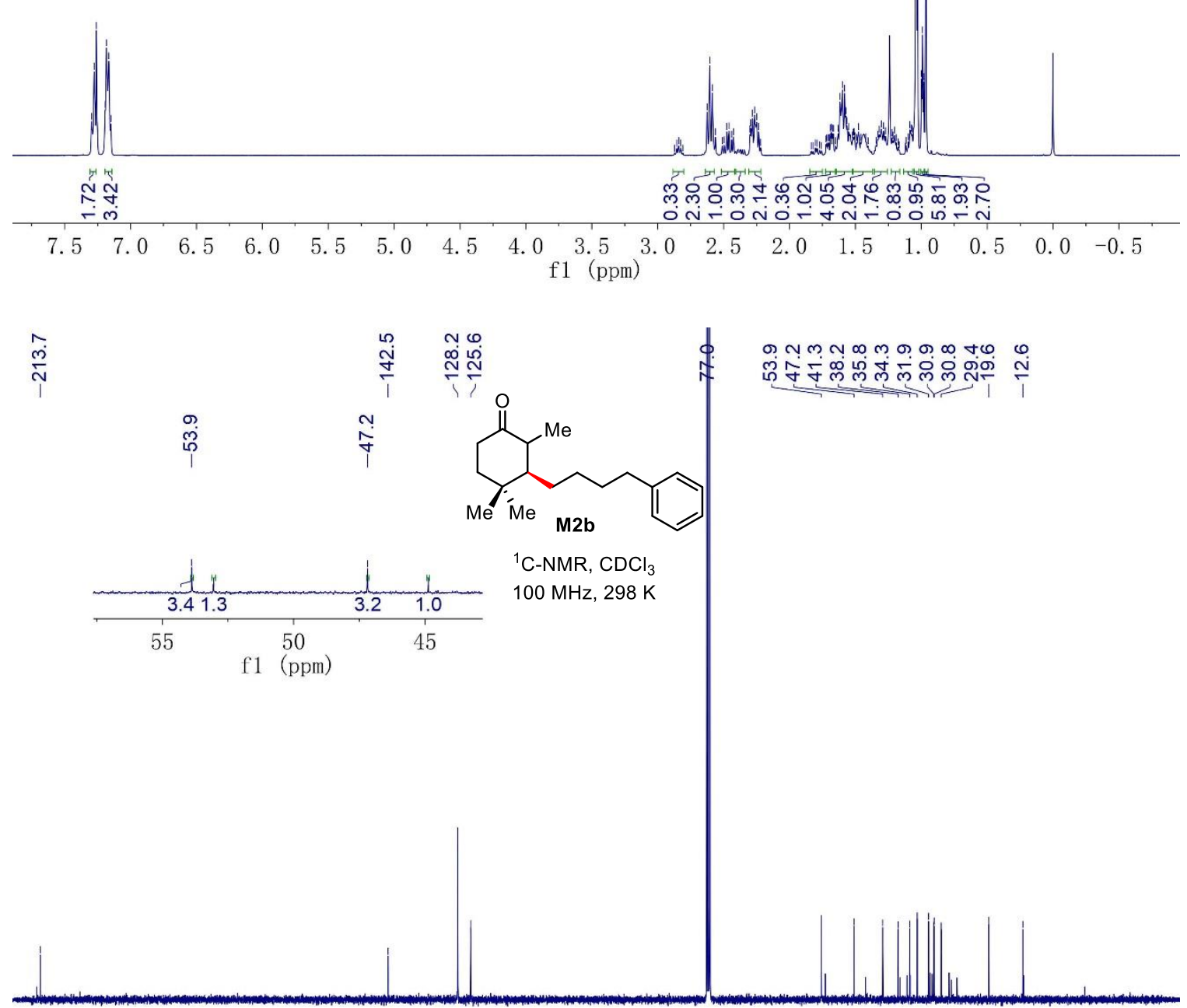

$\begin{array}{lllllllllllllllllllllll}210 & 200 & 190 & 180 & 170 & 160 & 150 & 140 & 130 & 120 & 110 & 100 & 90 & 80 & 70 & 60 & 50 & 40 & 30 & 20 & 10 & 0 & -10 \\ \text { f1 (ppm) }\end{array}$ 


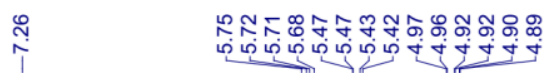

它他它

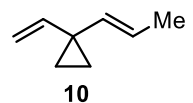

${ }^{1} \mathrm{H}-\mathrm{NMR}, \mathrm{CDCl}_{3}$

$400 \mathrm{MHz}, 298 \mathrm{~K}$

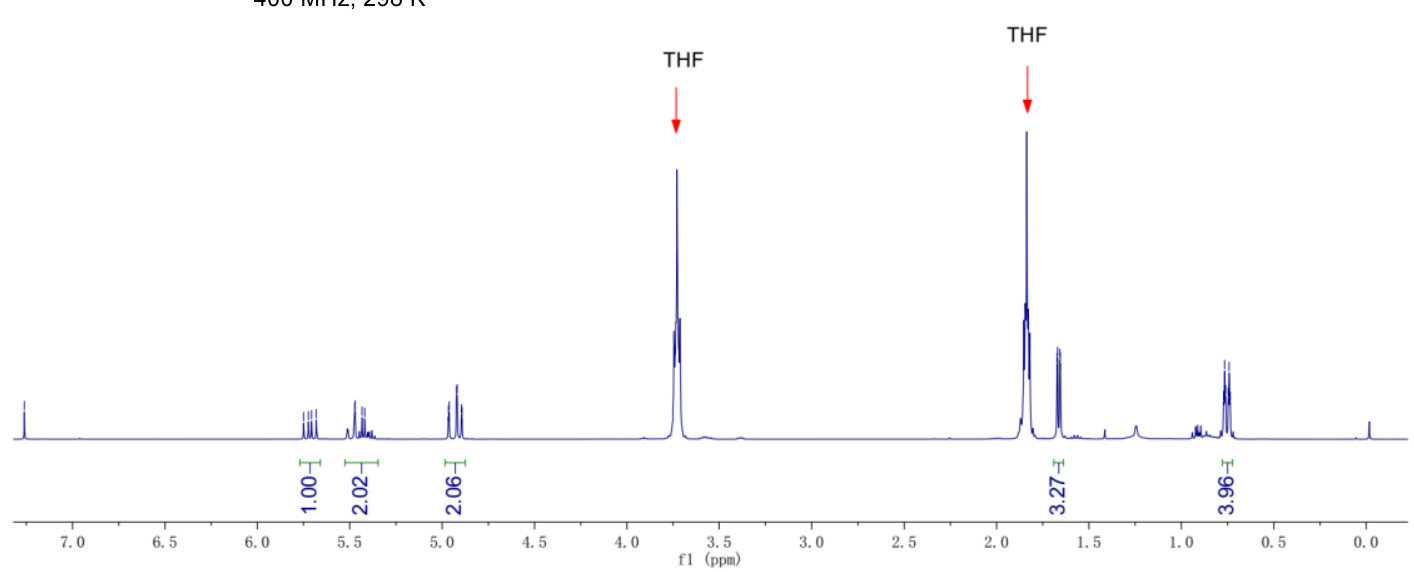

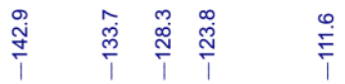

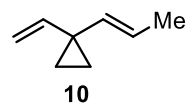

${ }^{13} \mathrm{C}-\mathrm{NMR}, \mathrm{CDCl}_{3}$

$100 \mathrm{MHz}, 298 \mathrm{~K}$

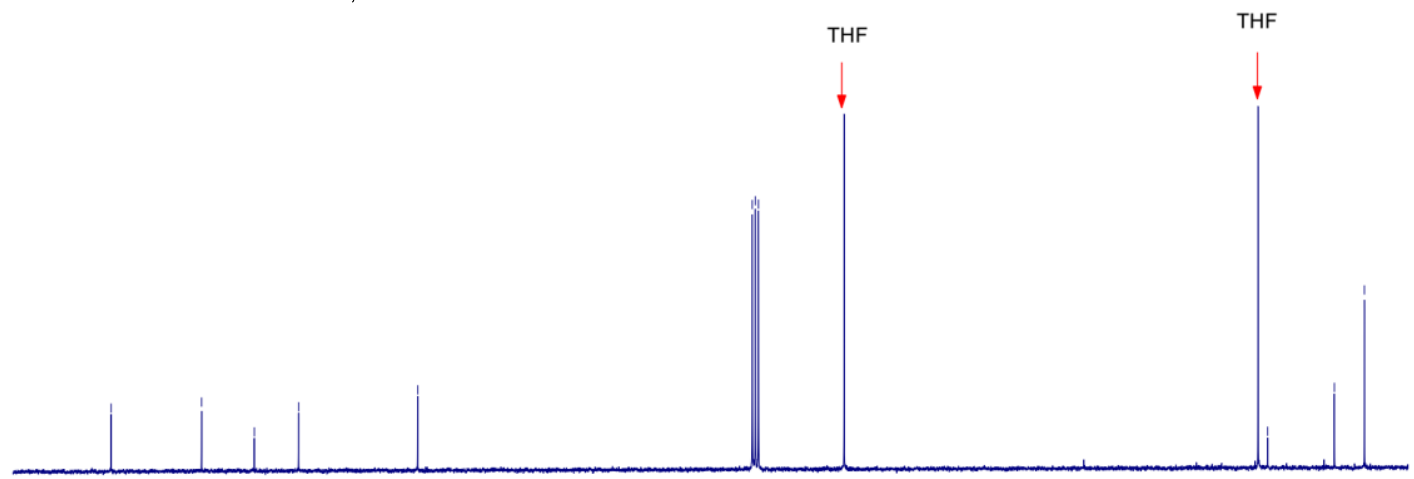

$\begin{array}{llllllllllllllllllllllllllllllllllllllll}150 & 145 & 140 & 135 & 130 & 125 & 120 & 115 & 110 & 105 & 100 & 95 & 90 & 85 & 80 & 75 & 70 & 65 & 60 & 55 & 50 & 45 & 40 & 35 & 30 & 25 & 20 & 15\end{array}$ 


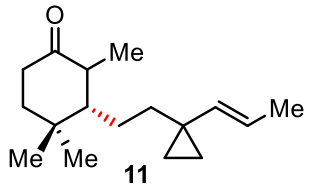

${ }^{1} \mathrm{H}-\mathrm{NMR}, \mathrm{CDCl}_{3}$ $400 \mathrm{MHz}, 298 \mathrm{~K}$

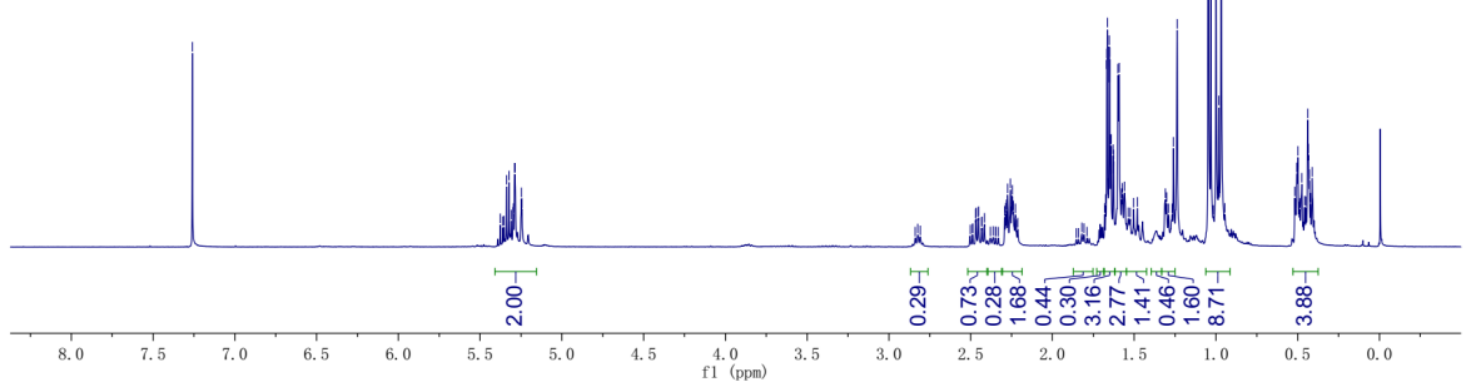

ำ

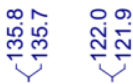

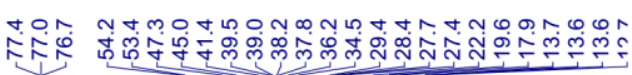<smiles>C/C=C/C1(CC[C@H]2C(C)C(=O)CCC2(C)C)CC1</smiles>

${ }^{13} \mathrm{C}-\mathrm{NMR}, \mathrm{CDCl}_{3}$

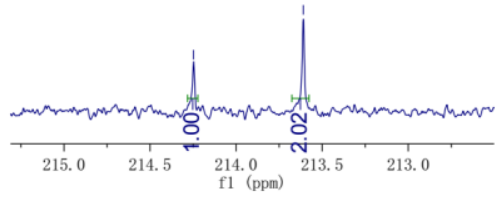

$100 \mathrm{MHz}, 298 \mathrm{~K}$

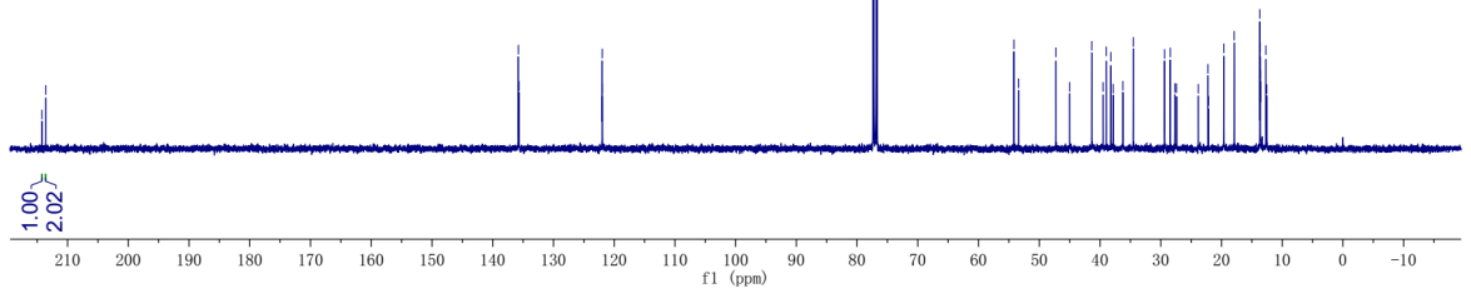




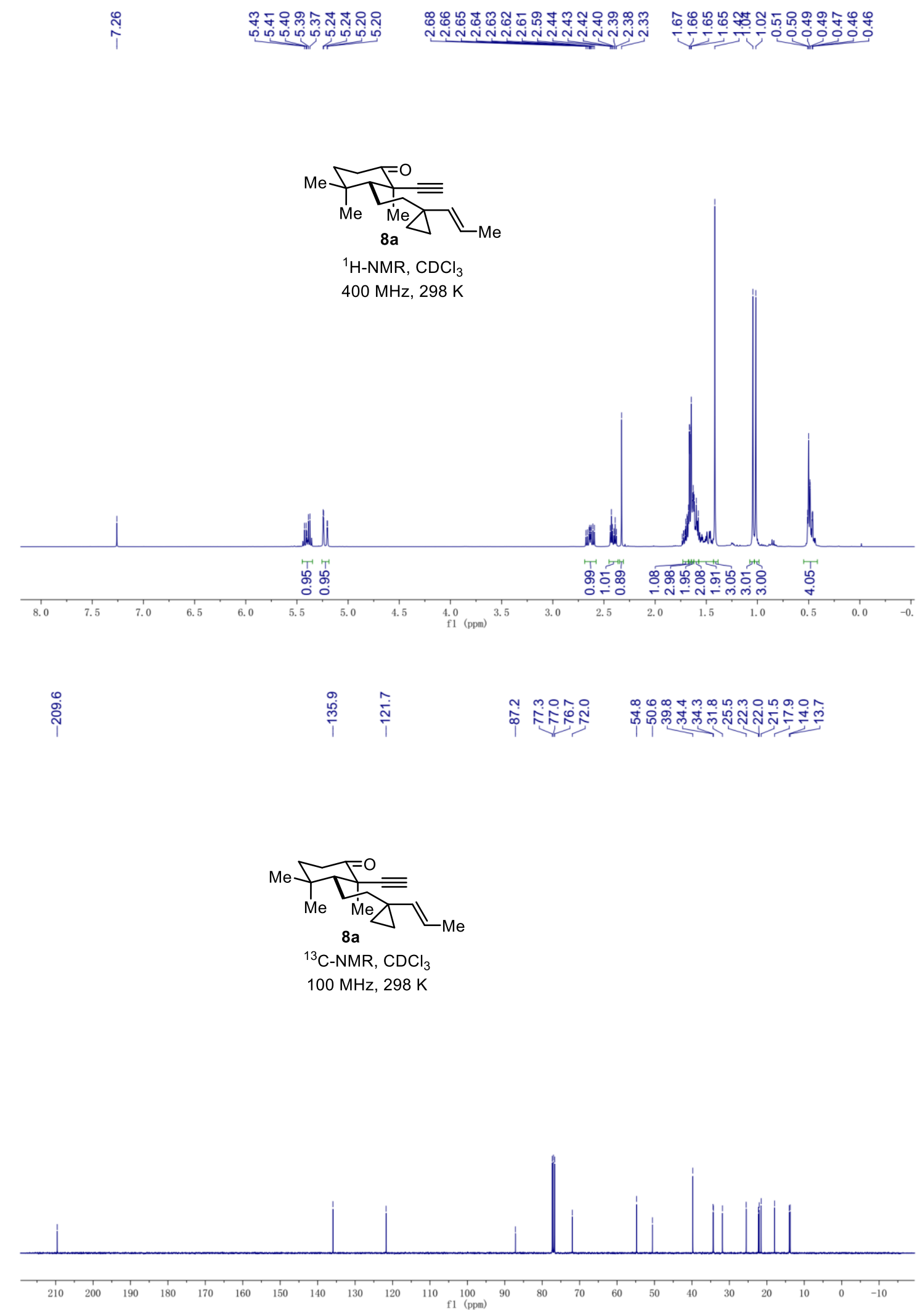


${ }^{1} \mathrm{H}-{ }^{1} \mathrm{H}$ COSY spectrum of $8 \mathrm{a}$
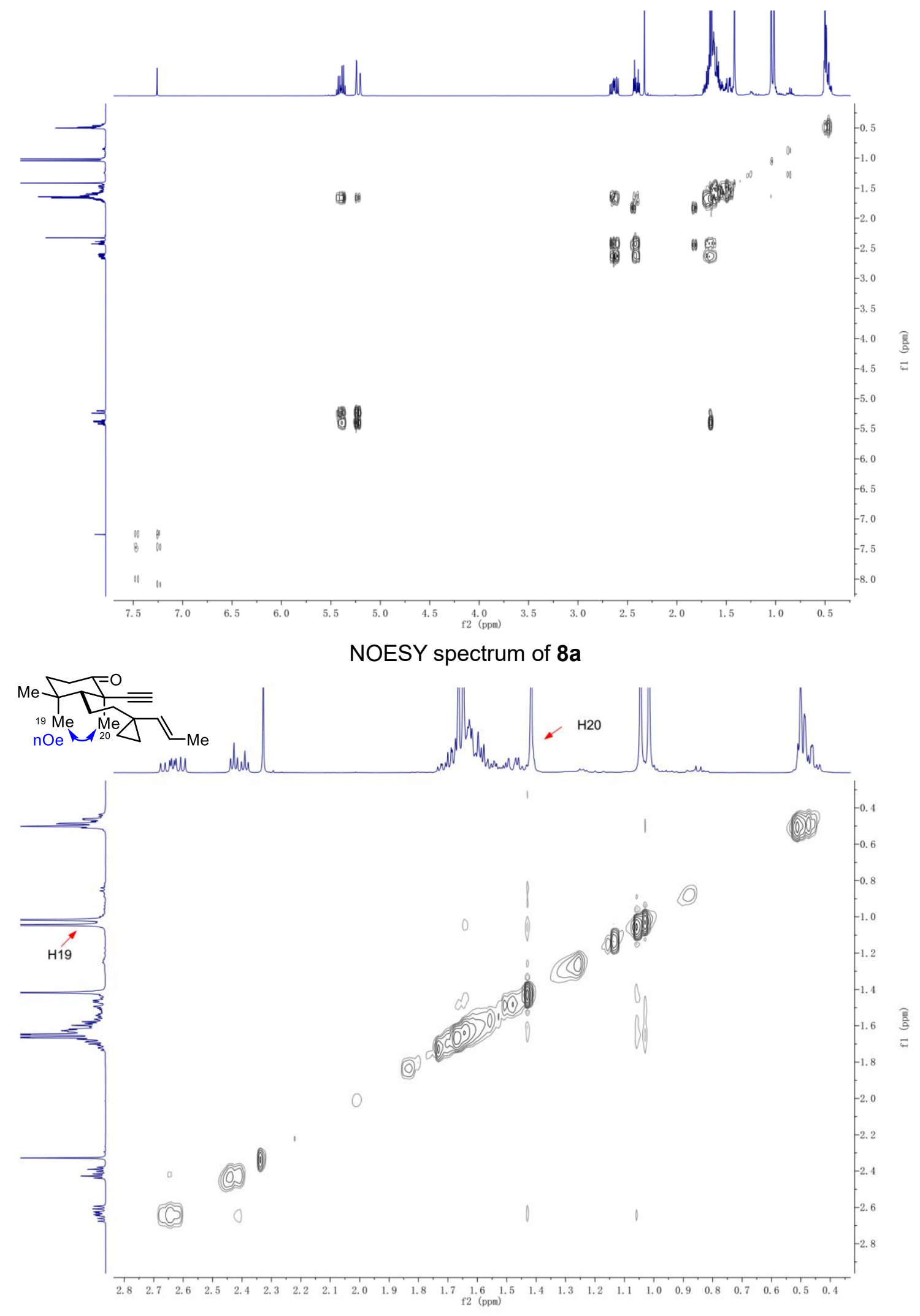


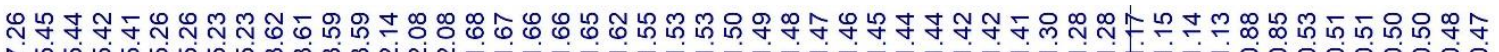

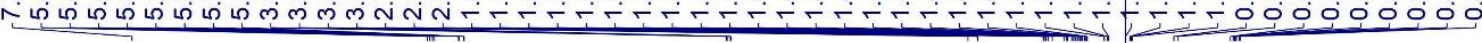
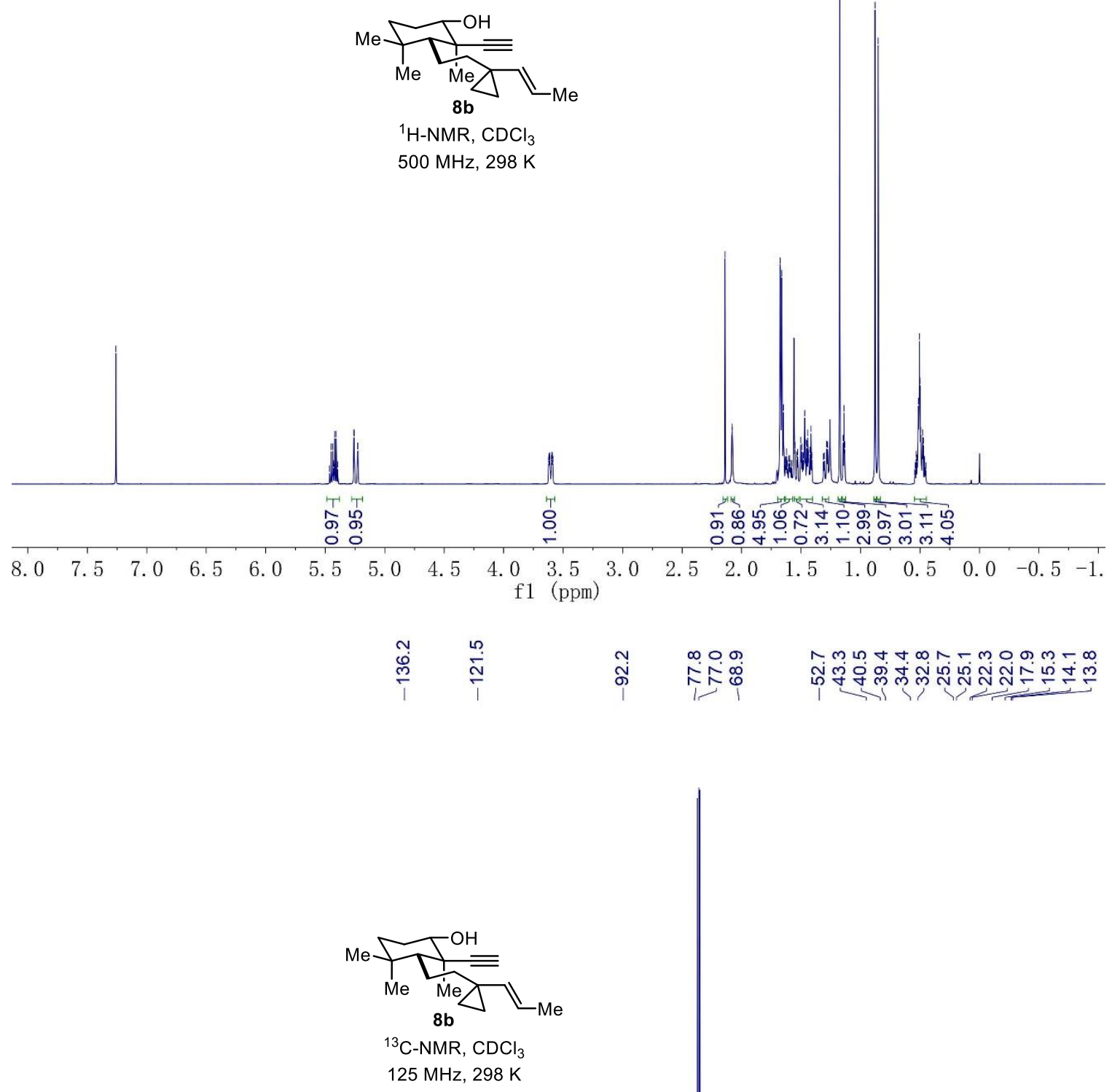

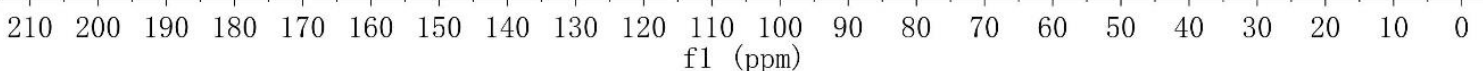




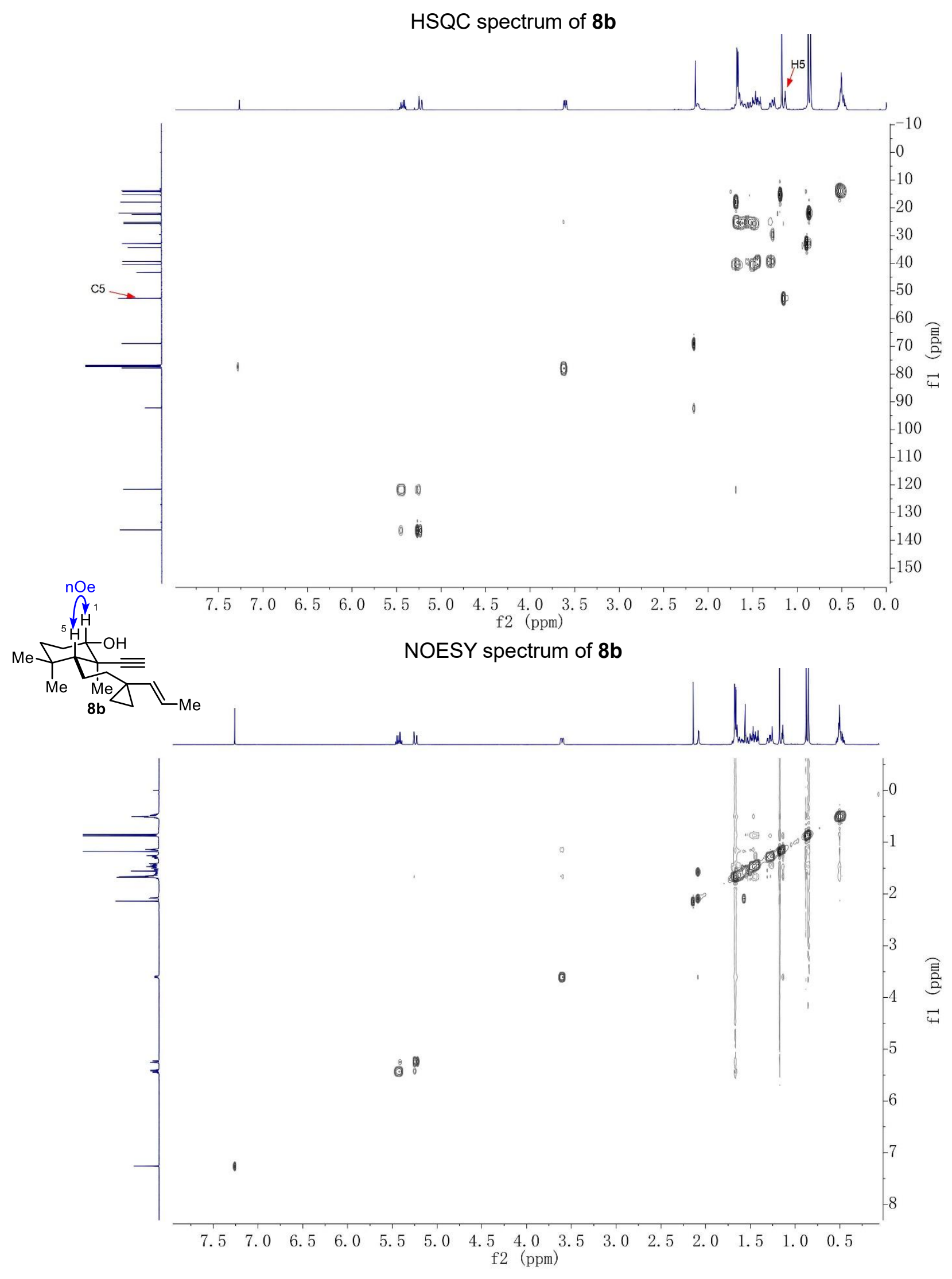




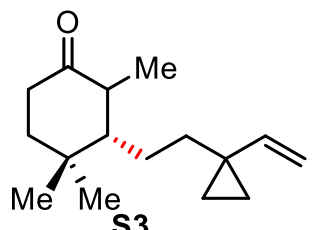

${ }^{1} \mathrm{H}-\mathrm{NMR}, \mathrm{CDCl}_{3}$ $400 \mathrm{MHz}, 298 \mathrm{~K}$
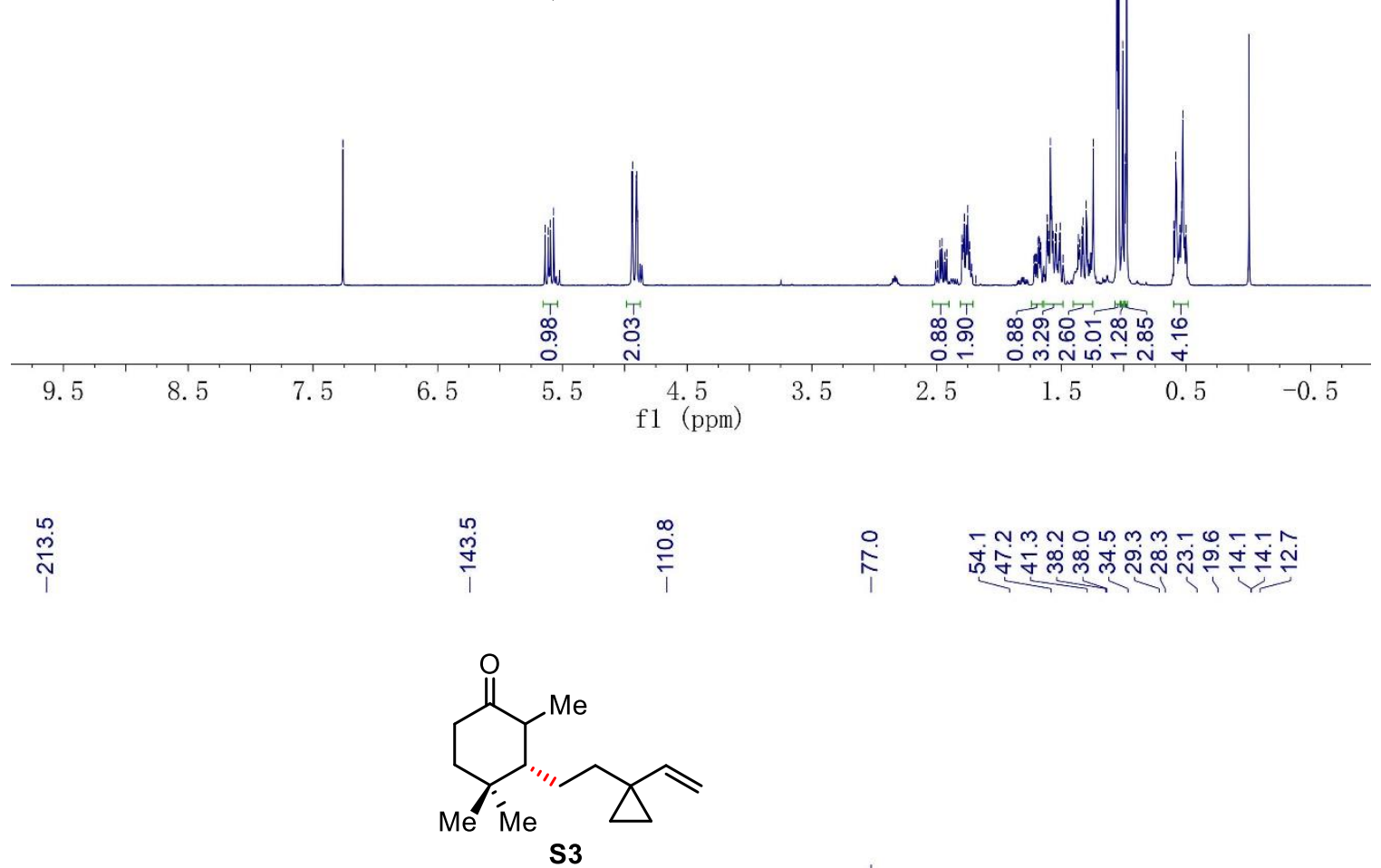

${ }^{13} \mathrm{C}-\mathrm{NMR}, \mathrm{CDCl}_{3}$ $100 \mathrm{MHz}, 298 \mathrm{~K}$

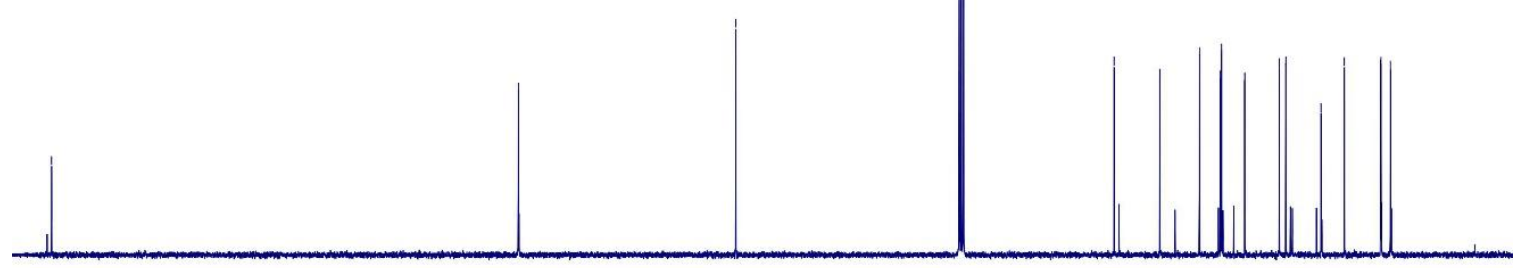

$\begin{array}{llllllllllllllllllllll}210 & 200 & 190 & 180 & 170 & 160 & 150 & 140 & 130 & 120 & \begin{array}{c}110 \\ \mathrm{f} 1\end{array}(\mathrm{ppm}) & 100 & 90 & 80 & 70 & 60 & 50 & 40 & 30 & 20 & 10 & 0\end{array}$ 


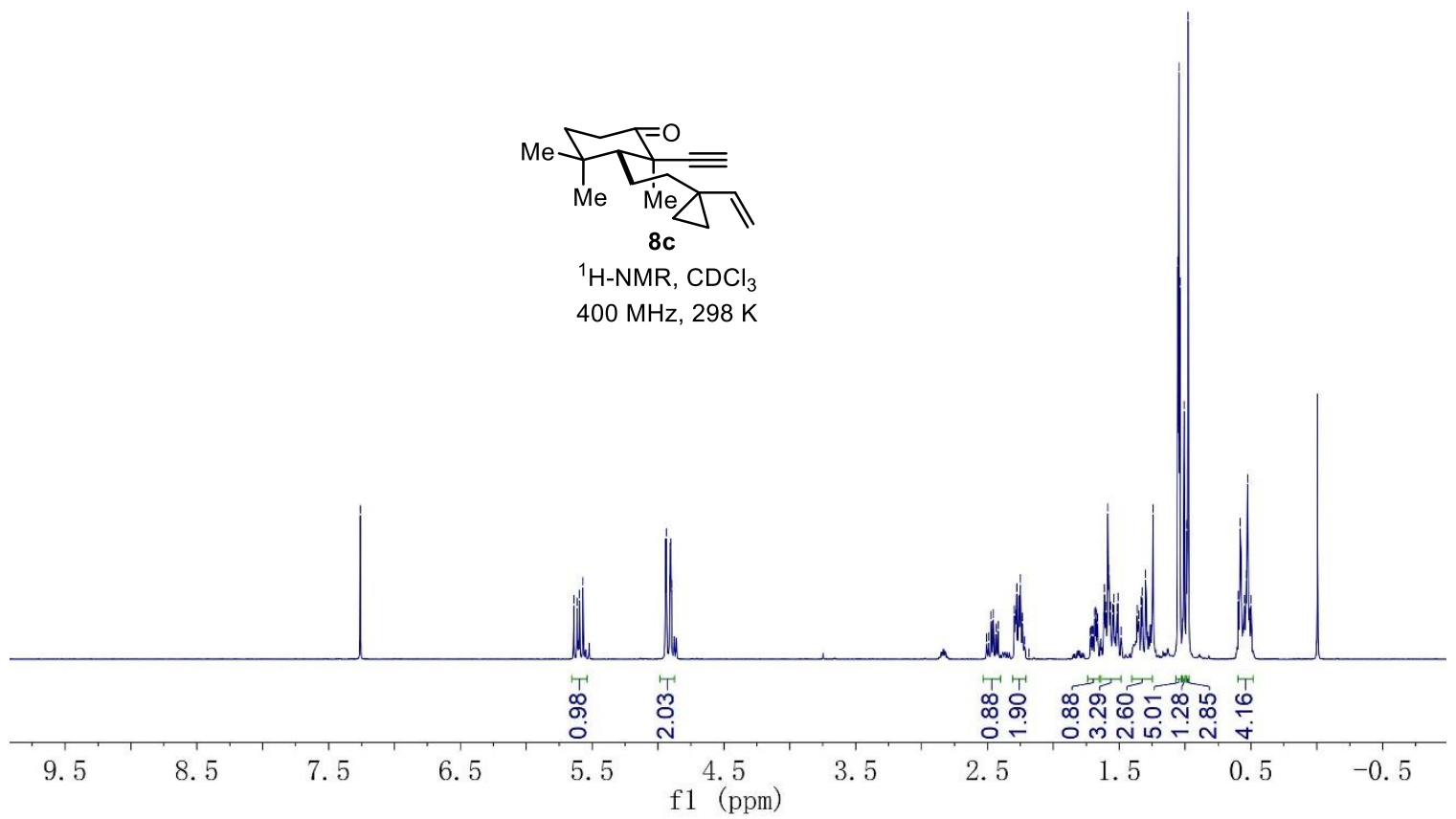

ํㅜㅇ
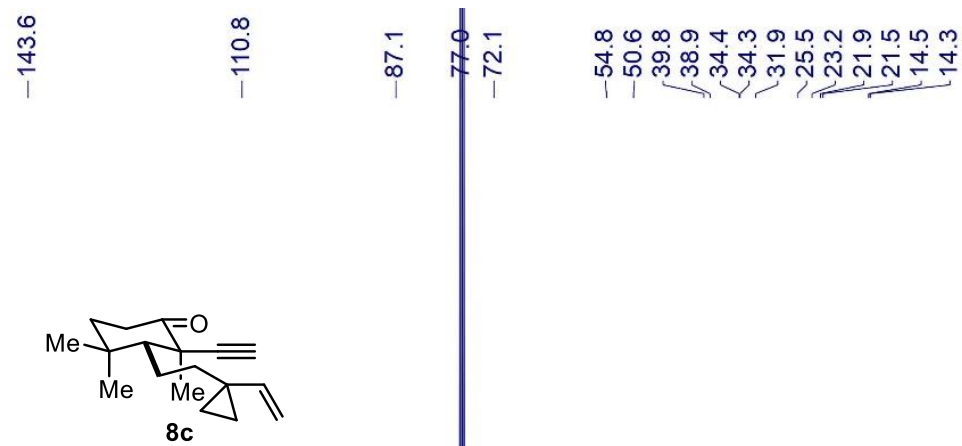

${ }^{13} \mathrm{C}-\mathrm{NMR}, \mathrm{CDCl}_{3}$

$125 \mathrm{MHz}, 298 \mathrm{~K}$

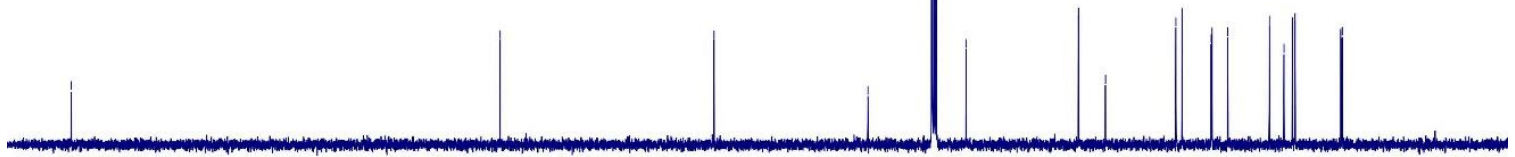

$\begin{array}{lllllllllllllllllllllll}210 & 200 & 190 & 180 & 170 & 160 & 150 & 140 & 130 & 120 & 110 & 100 & 90 & 80 & 70 & 60 & 50 & 40 & 30 & 20 & 10 & 0 & -1 \\ \mathrm{f} 1 & (\mathrm{ppm})\end{array}$ 

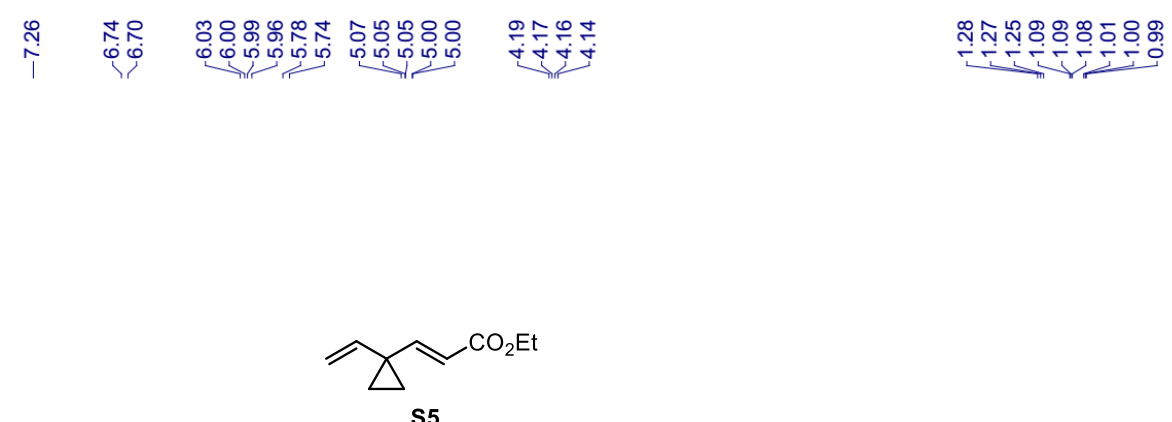

${ }^{1} \mathrm{H}-\mathrm{NMR}, \mathrm{CDCl}_{3}$ $400 \mathrm{MHz}, 298 \mathrm{~K}$
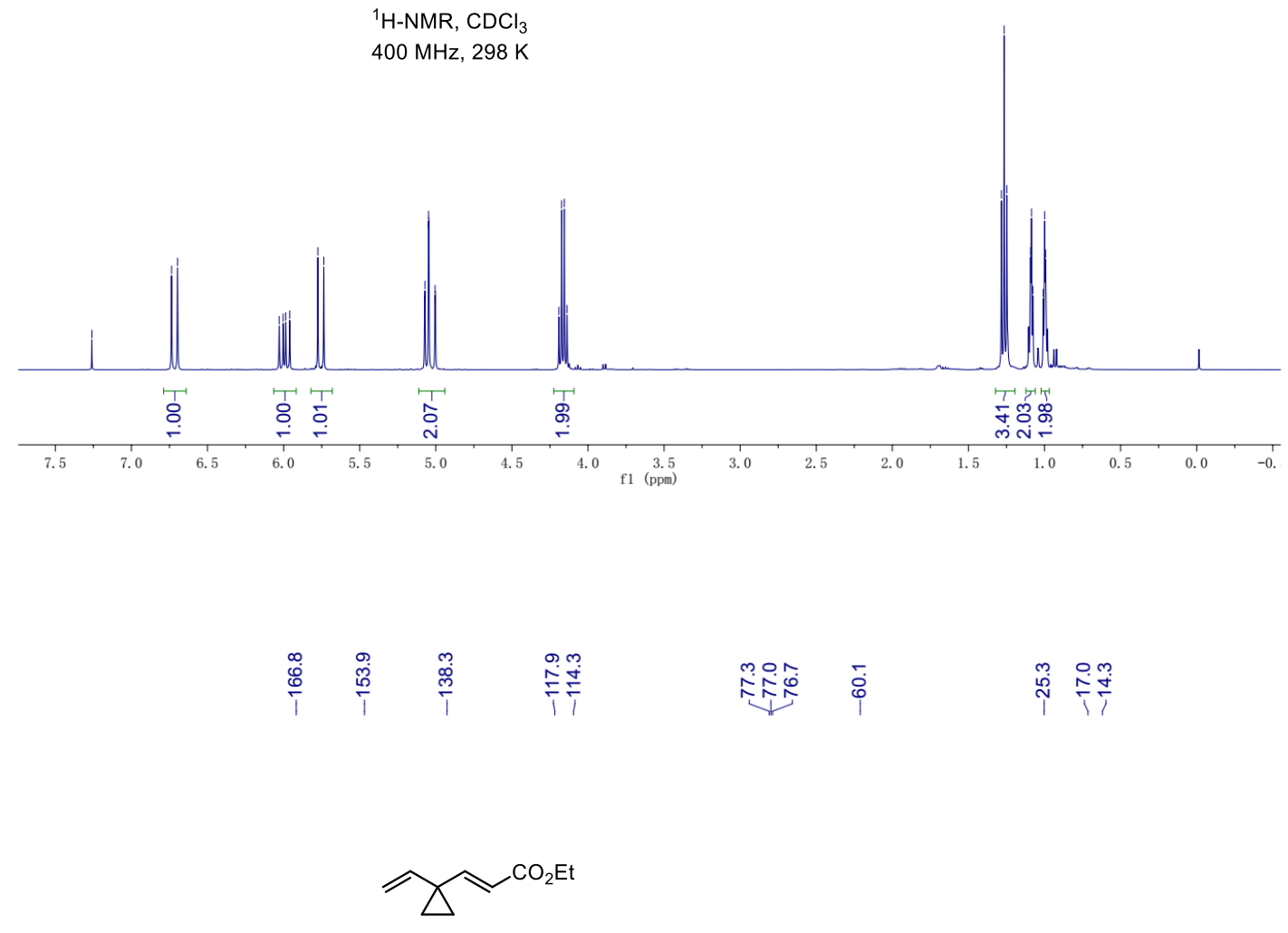

S5

${ }^{13} \mathrm{C}-\mathrm{NMR}, \mathrm{CDCl}_{3}$

$100 \mathrm{MHz}, 298 \mathrm{~K}$

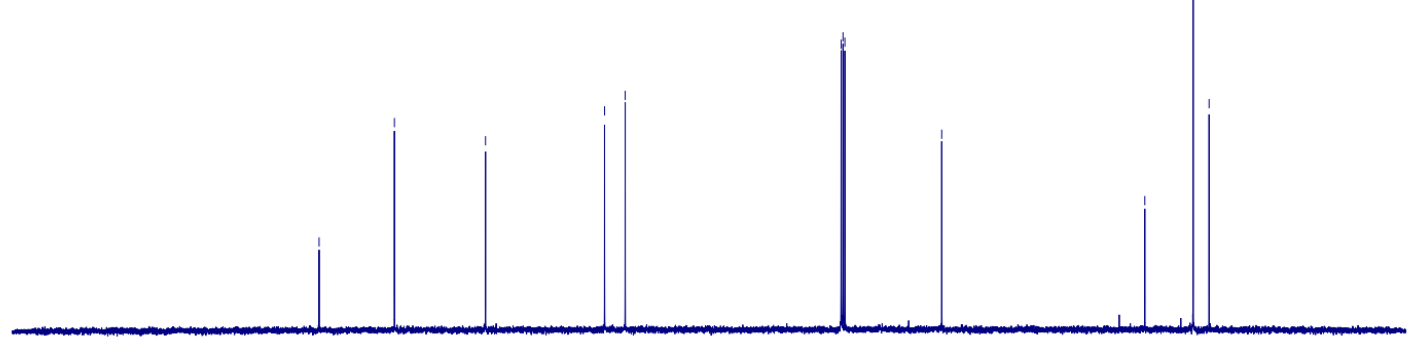

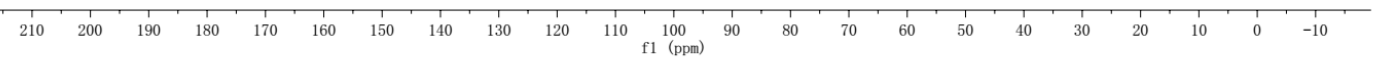




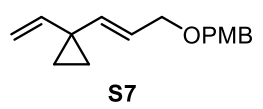

${ }^{1} \mathrm{H}-\mathrm{NMR}, \mathrm{CDCl}_{3}$ $400 \mathrm{MHz}, 298 \mathrm{~K}$
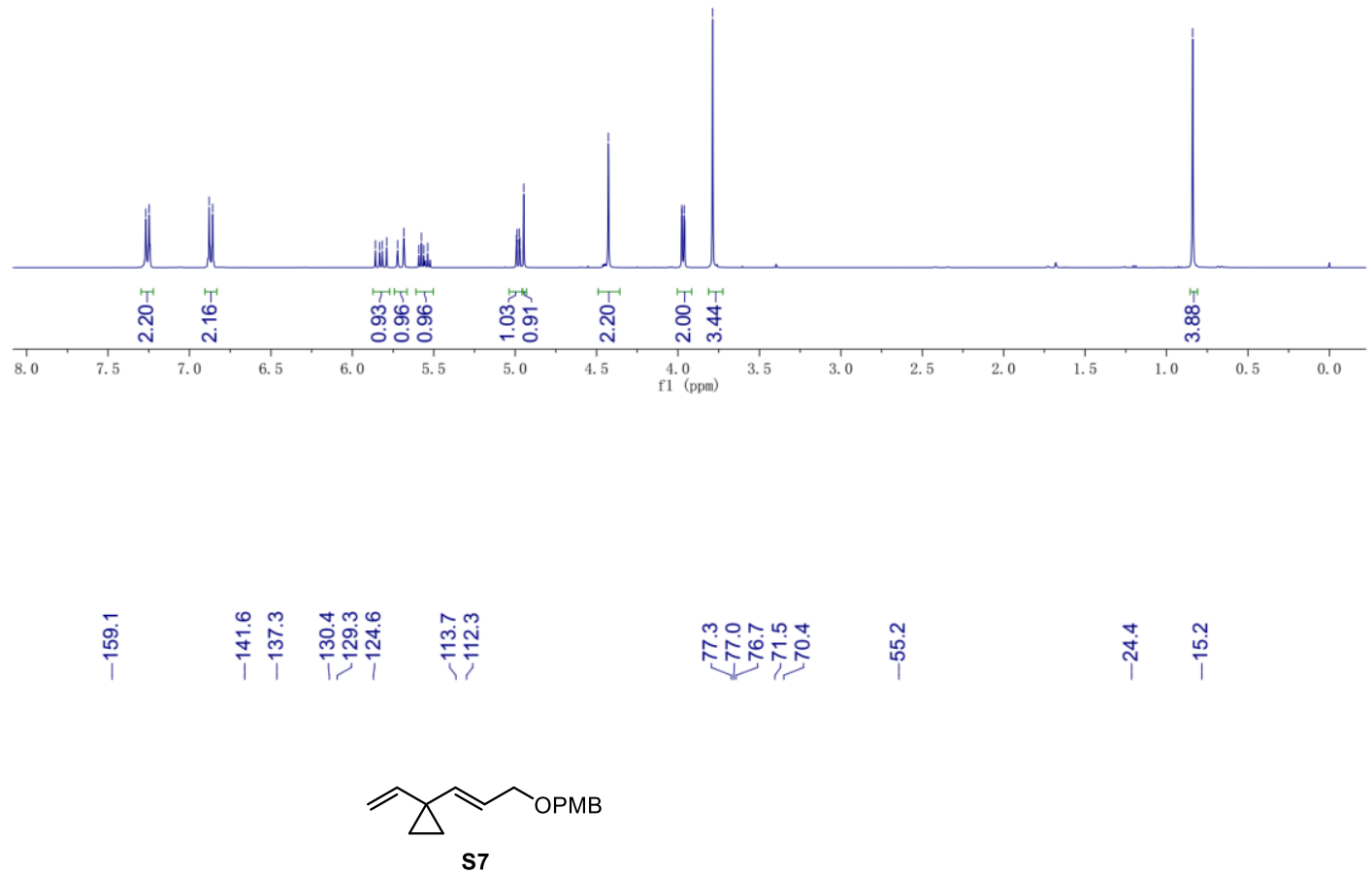

${ }^{13} \mathrm{C}-\mathrm{NMR}, \mathrm{CDCl}_{3}$ $100 \mathrm{MHz}, 298 \mathrm{~K}$
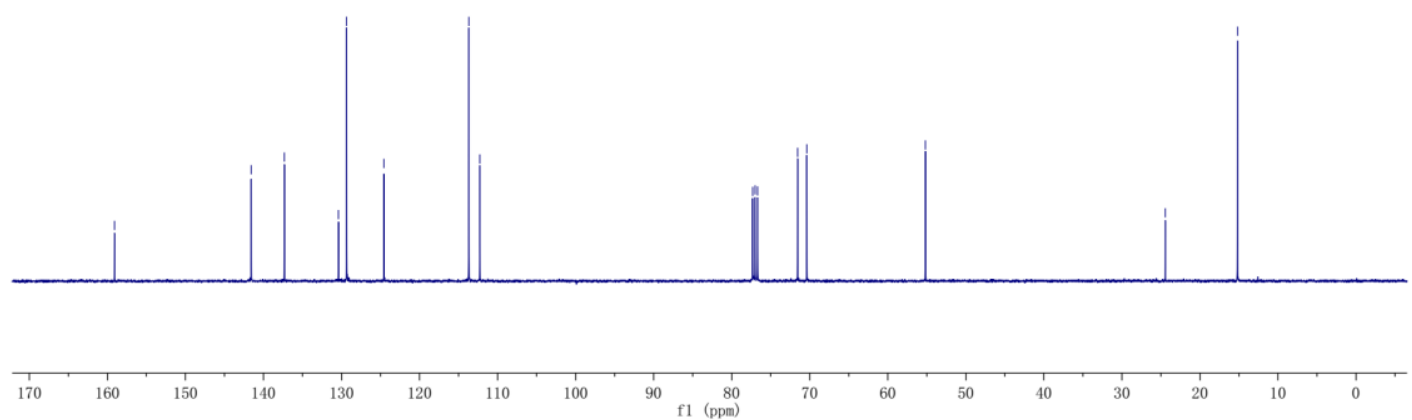

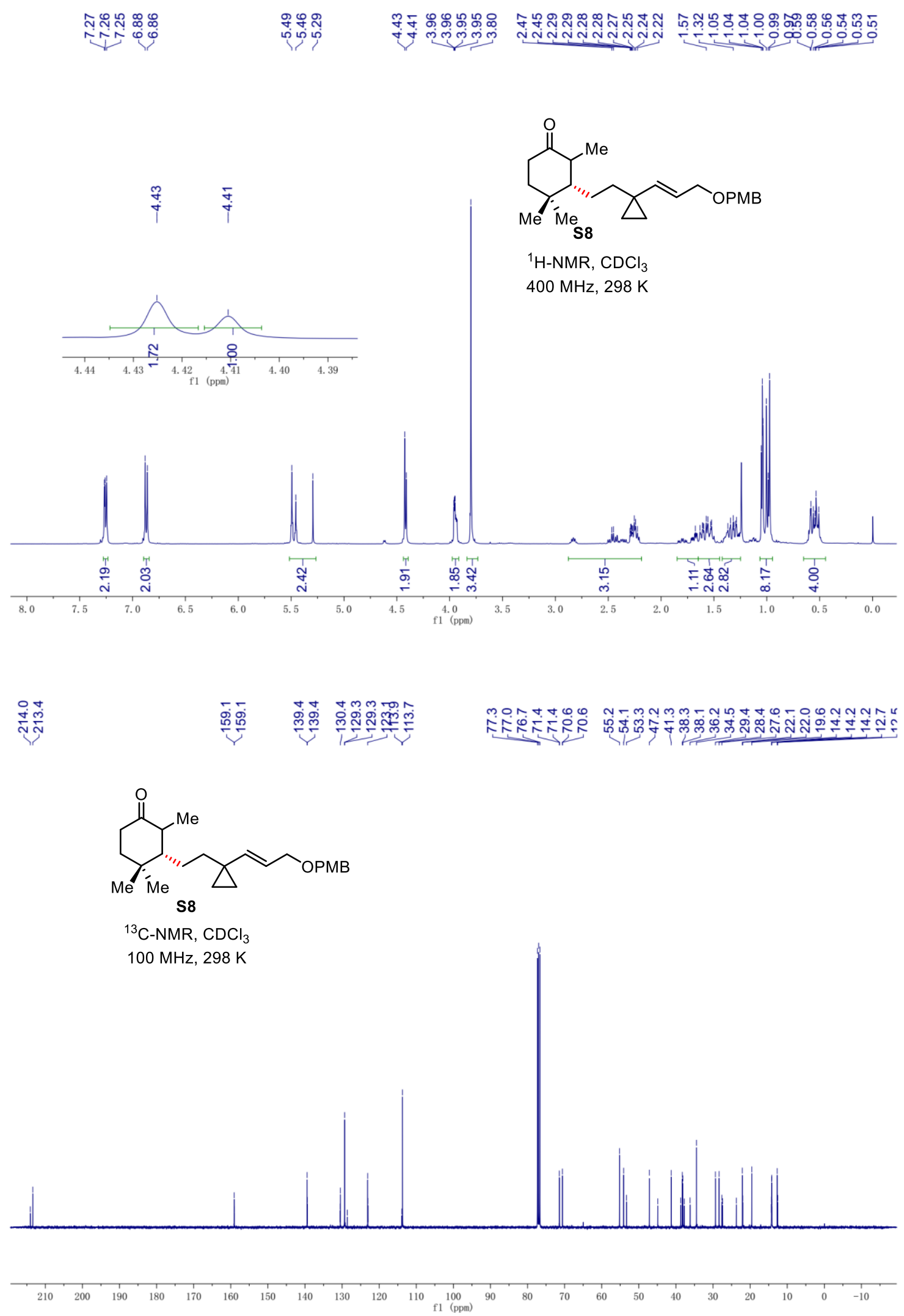

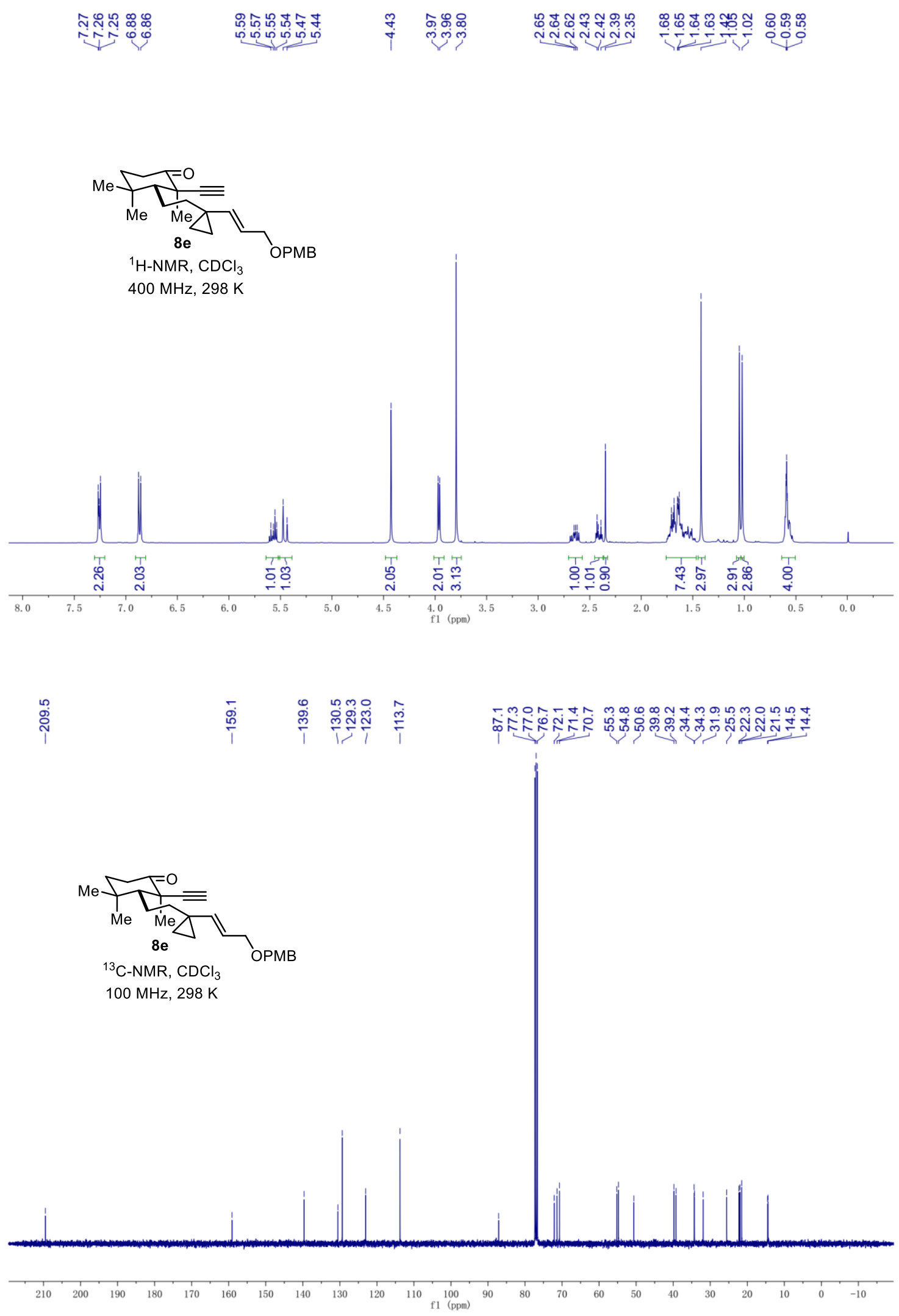

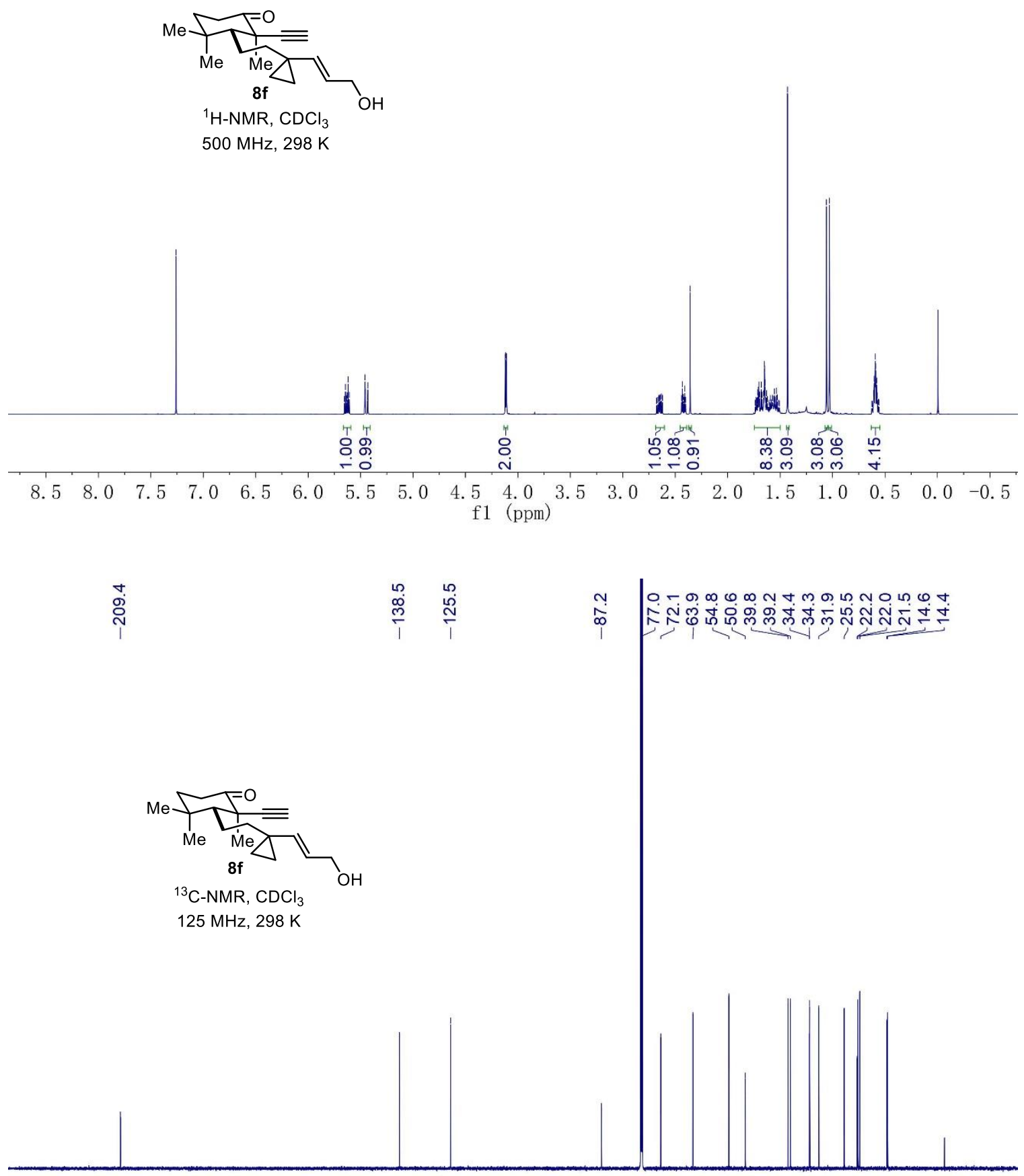

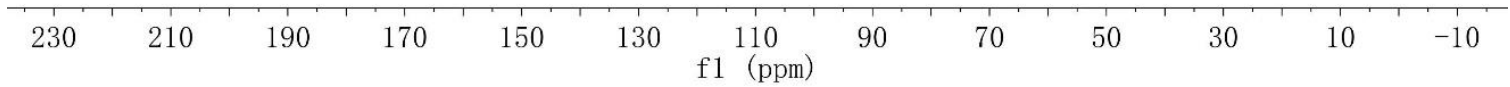




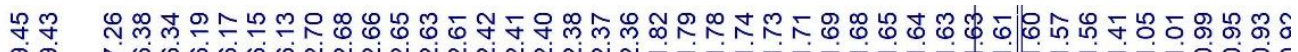

gु ก

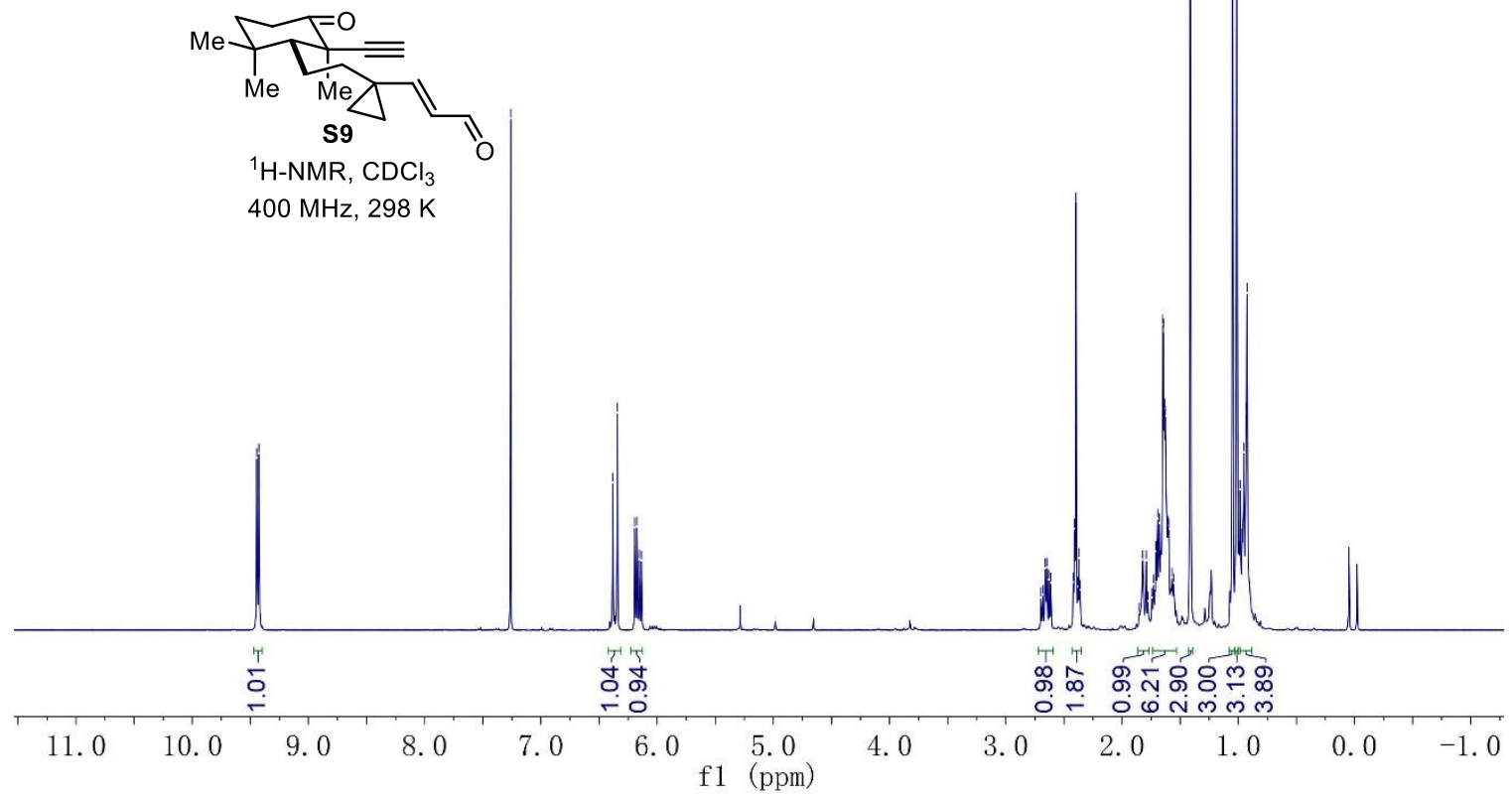

家
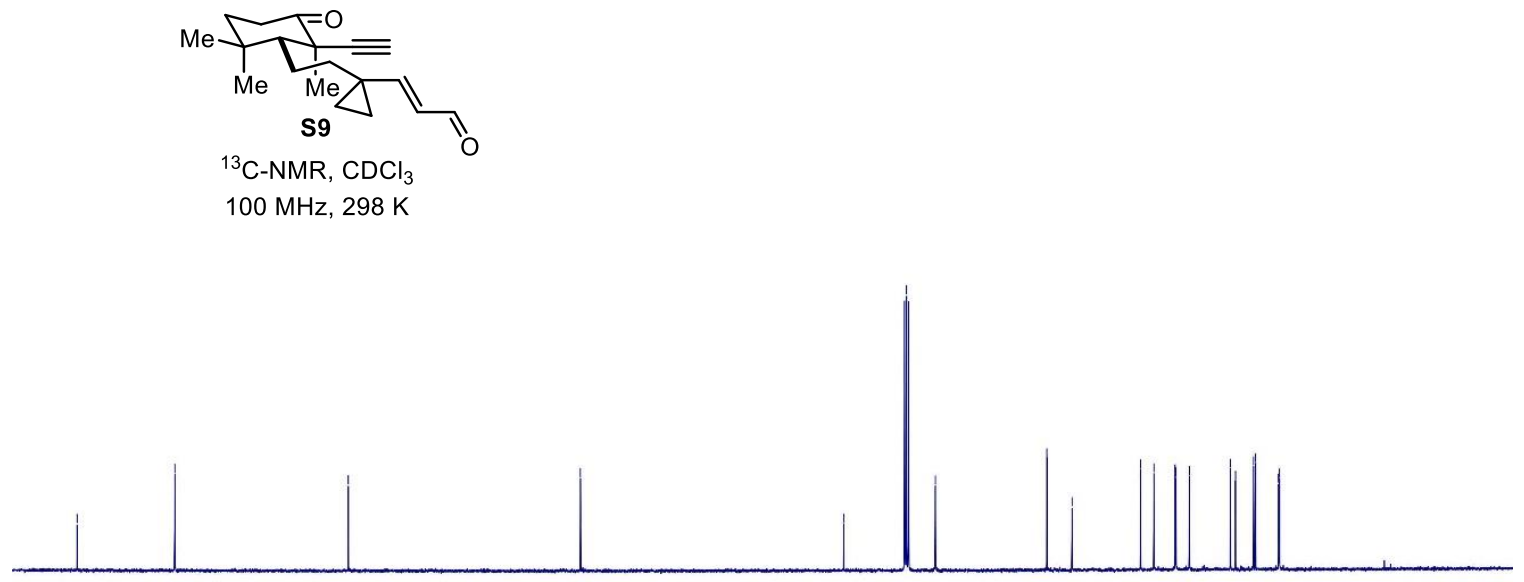

$\begin{array}{lllllllllllllllllllllll}210 & 200 & 190 & 180 & 170 & 160 & 150 & 140 & 130 & 120 & 110 & 100 & 90 & 80 & 70 & 60 & 50 & 40 & 30 & 20 & 10 & 0 & -10\end{array}$ f1 (ppm) 
꿌ㅆ rọ
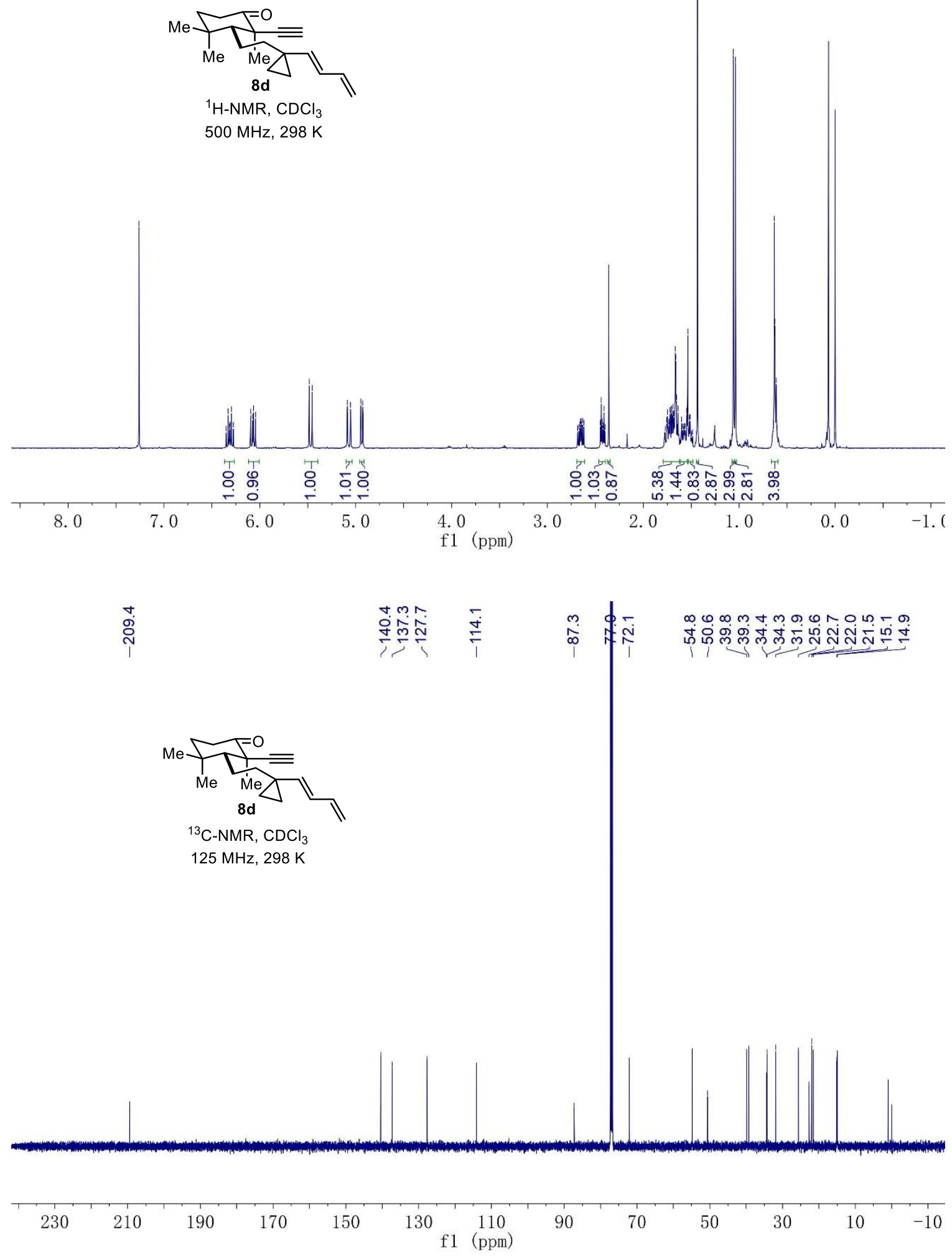


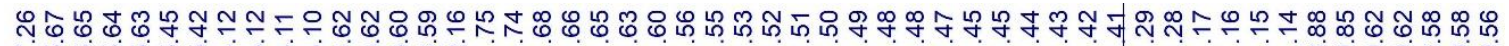

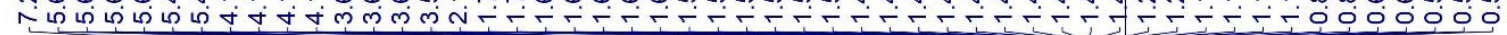
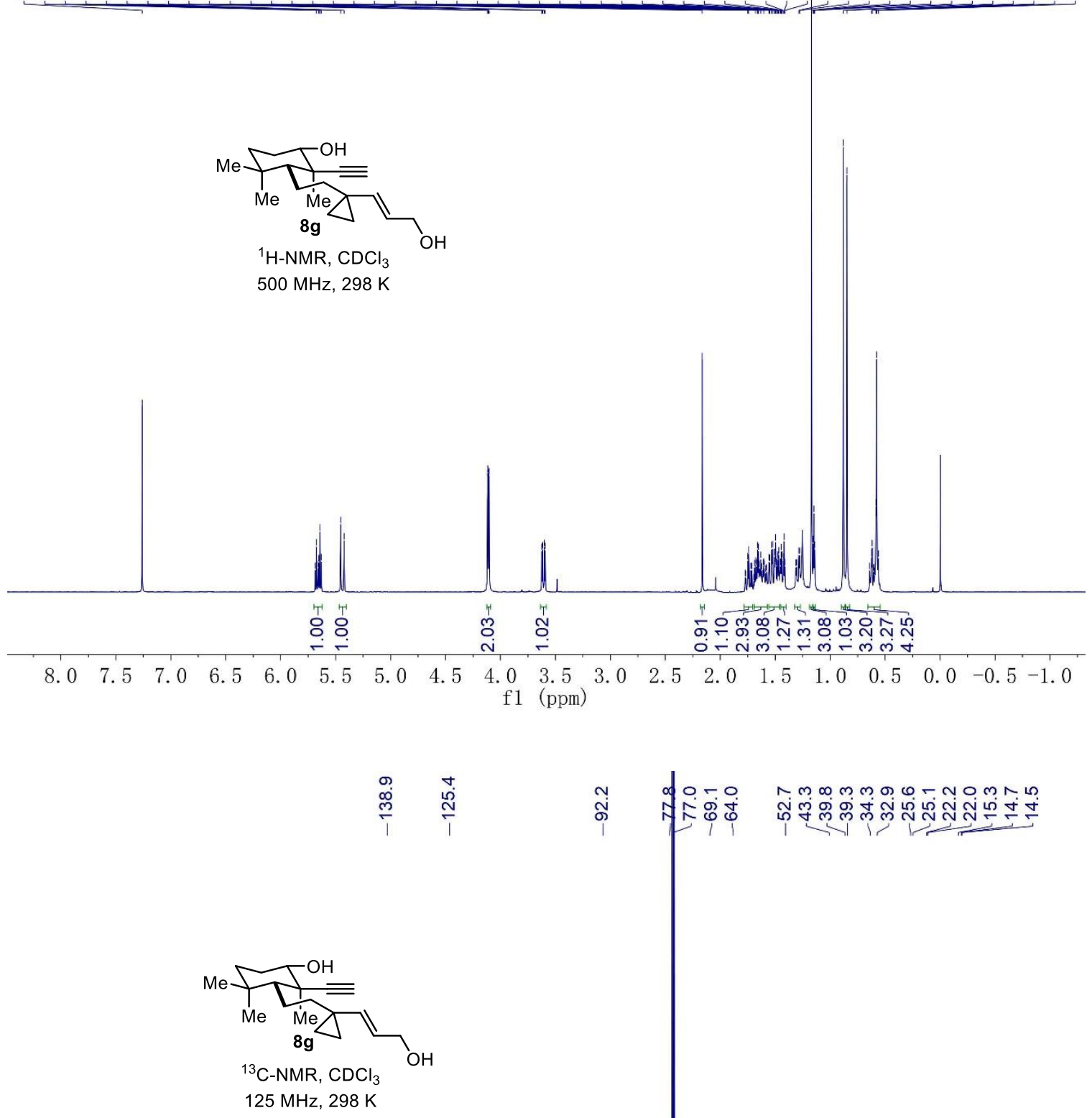

$\begin{array}{llllllllllllllllllllllll}20 & 210 & 200 & 190 & 180 & 170 & 160 & 150 & 140 & 130 & 120 & 110 & 100 & 90 & 80 & 70 & 60 & 50 & 40 & 30 & 20 & 10 & 0 & -1(\end{array}$ 


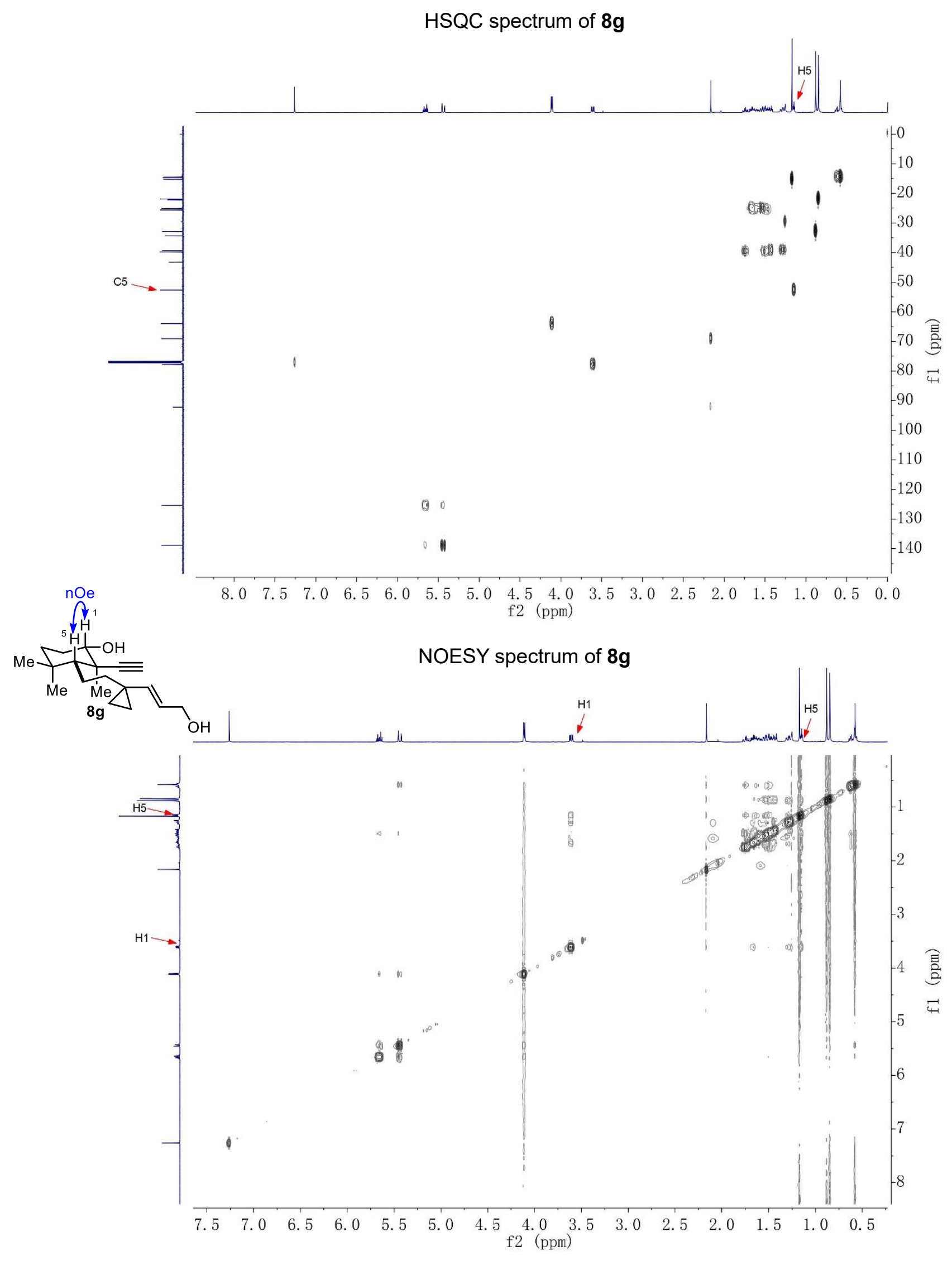



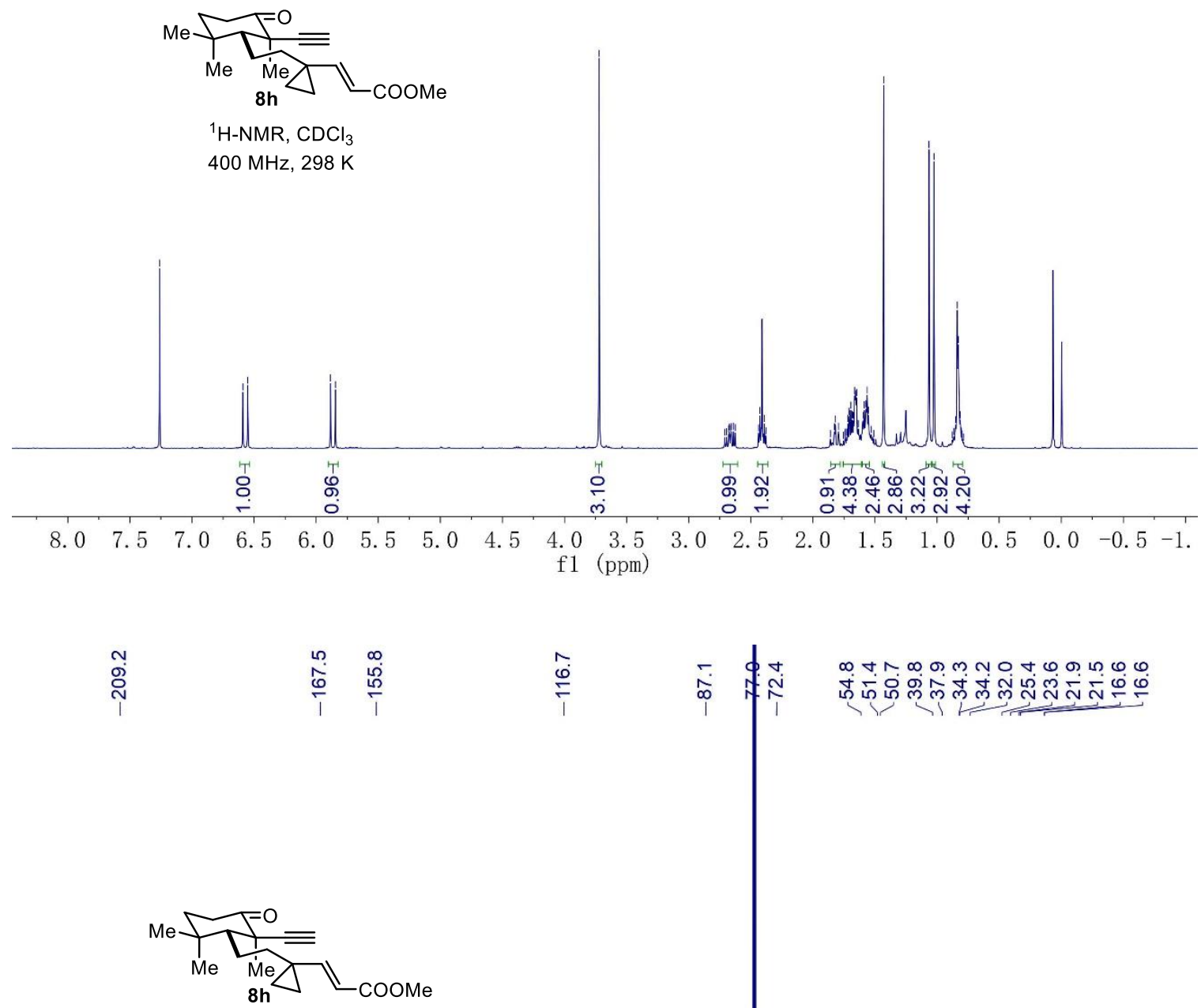

${ }^{13} \mathrm{C}-\mathrm{NMR}, \mathrm{CDCl}_{3}$

$125 \mathrm{MHz}, 298 \mathrm{~K}$

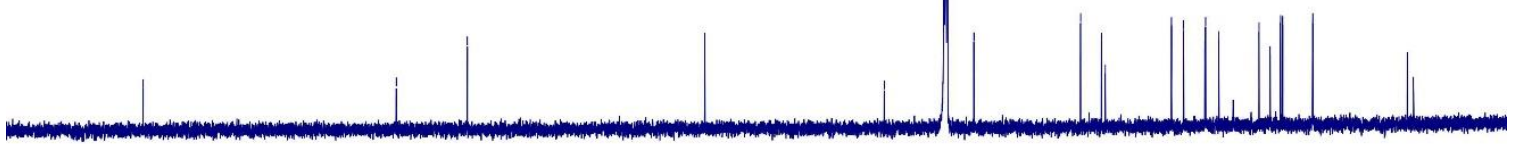

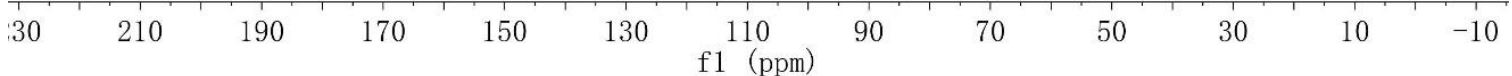



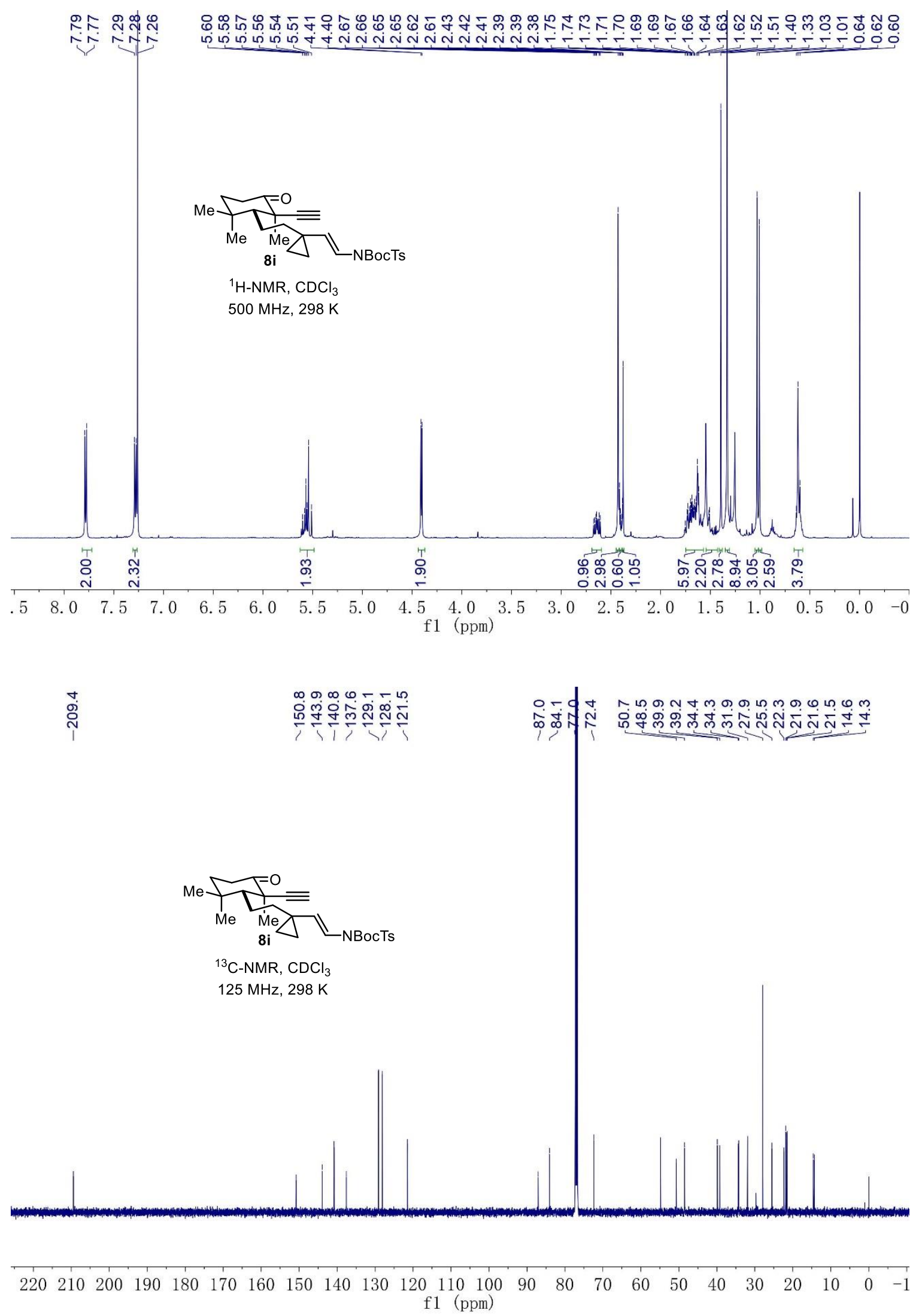


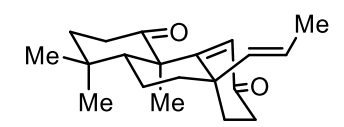

$7 a$

${ }^{1} \mathrm{H}-\mathrm{NMR}, \mathrm{CDCl}_{3}$ $400 \mathrm{MHz}, 298 \mathrm{~K}$

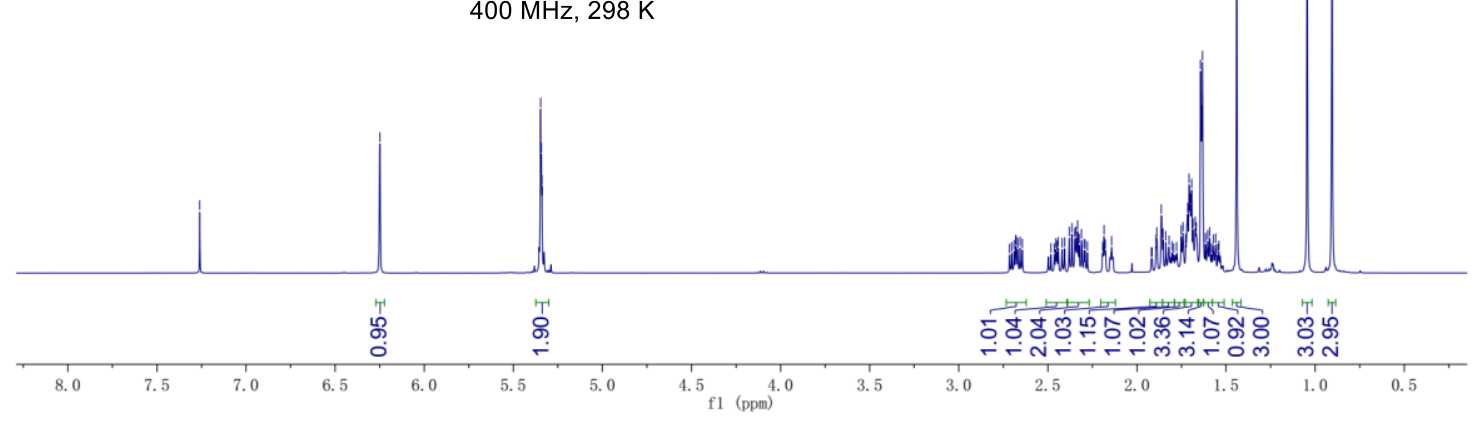

\begin{tabular}{|c|c|c|c|c|}
\hline ஷั่ & 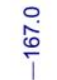 & 芦啇过 & mon & 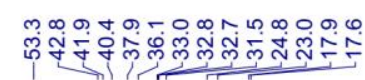 \\
\hline
\end{tabular}

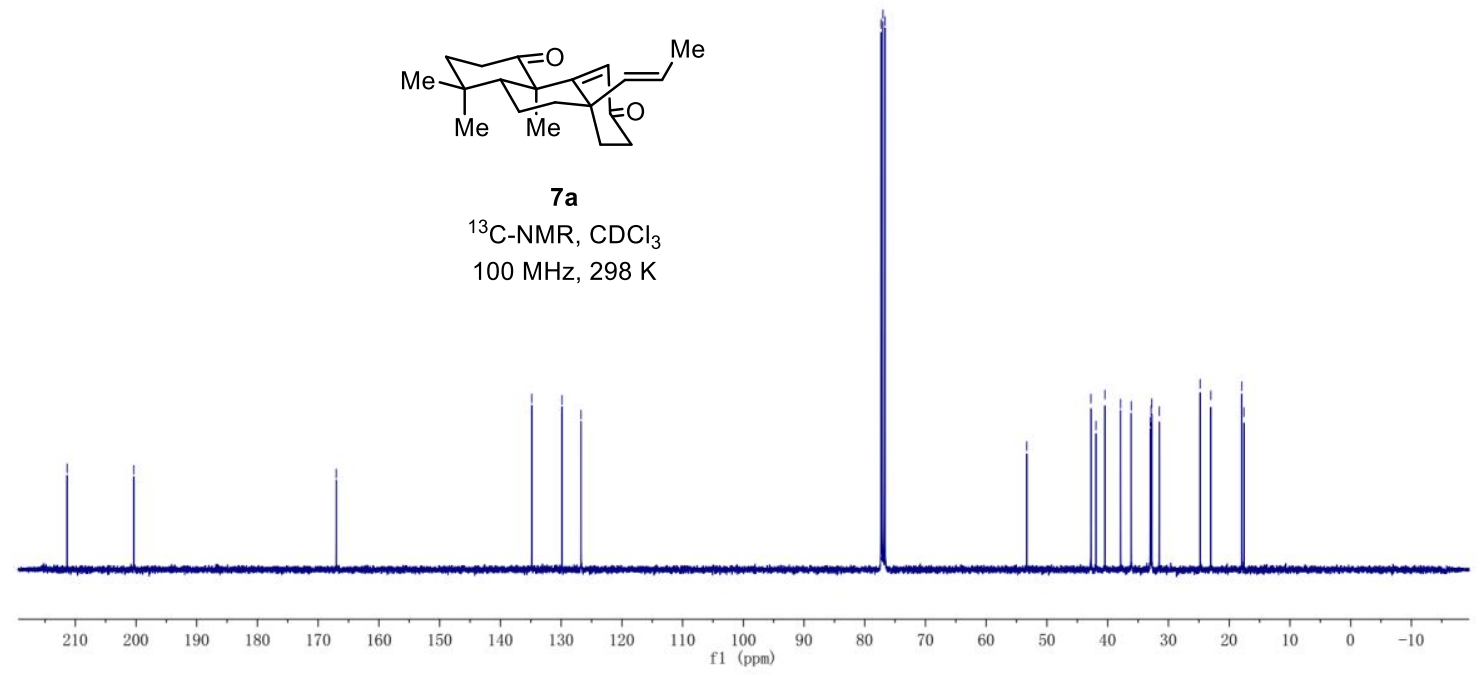


${ }^{1} \mathrm{H}-{ }^{1} \mathrm{H}$ COSY spectrum of $7 \mathrm{a}$

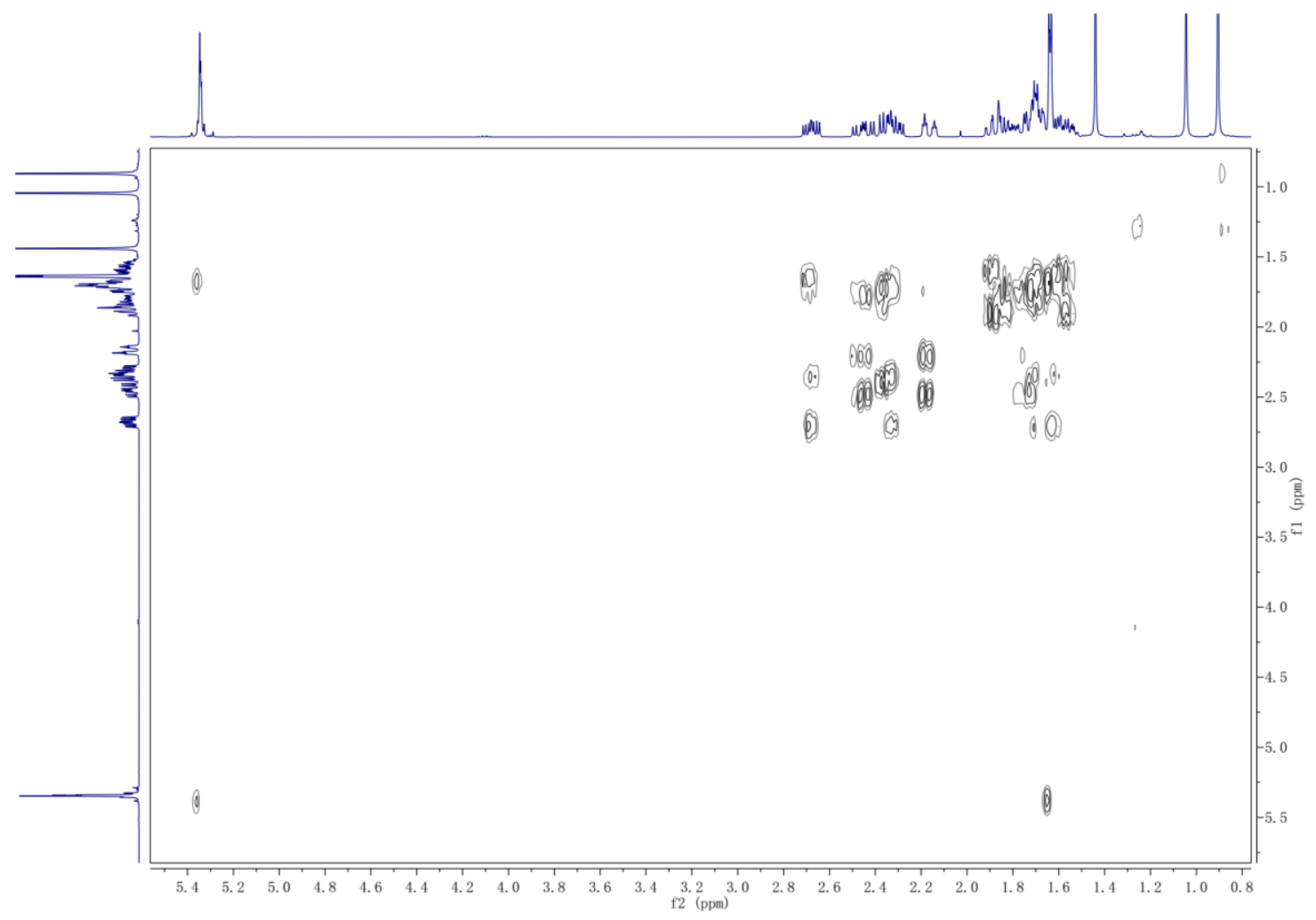

HSQC spectrum of $7 \mathbf{a}$

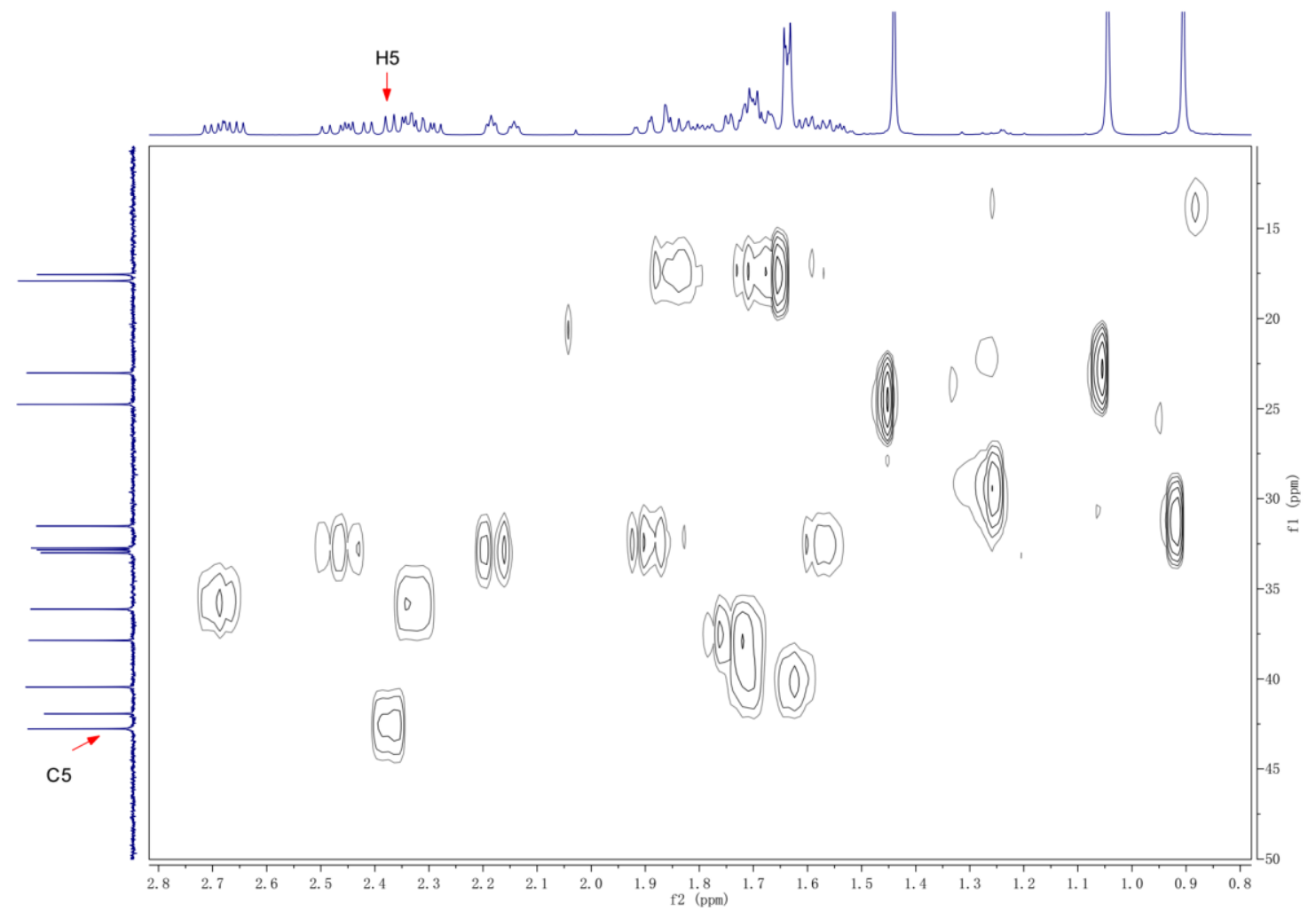


HMBC spectrum of $7 a$
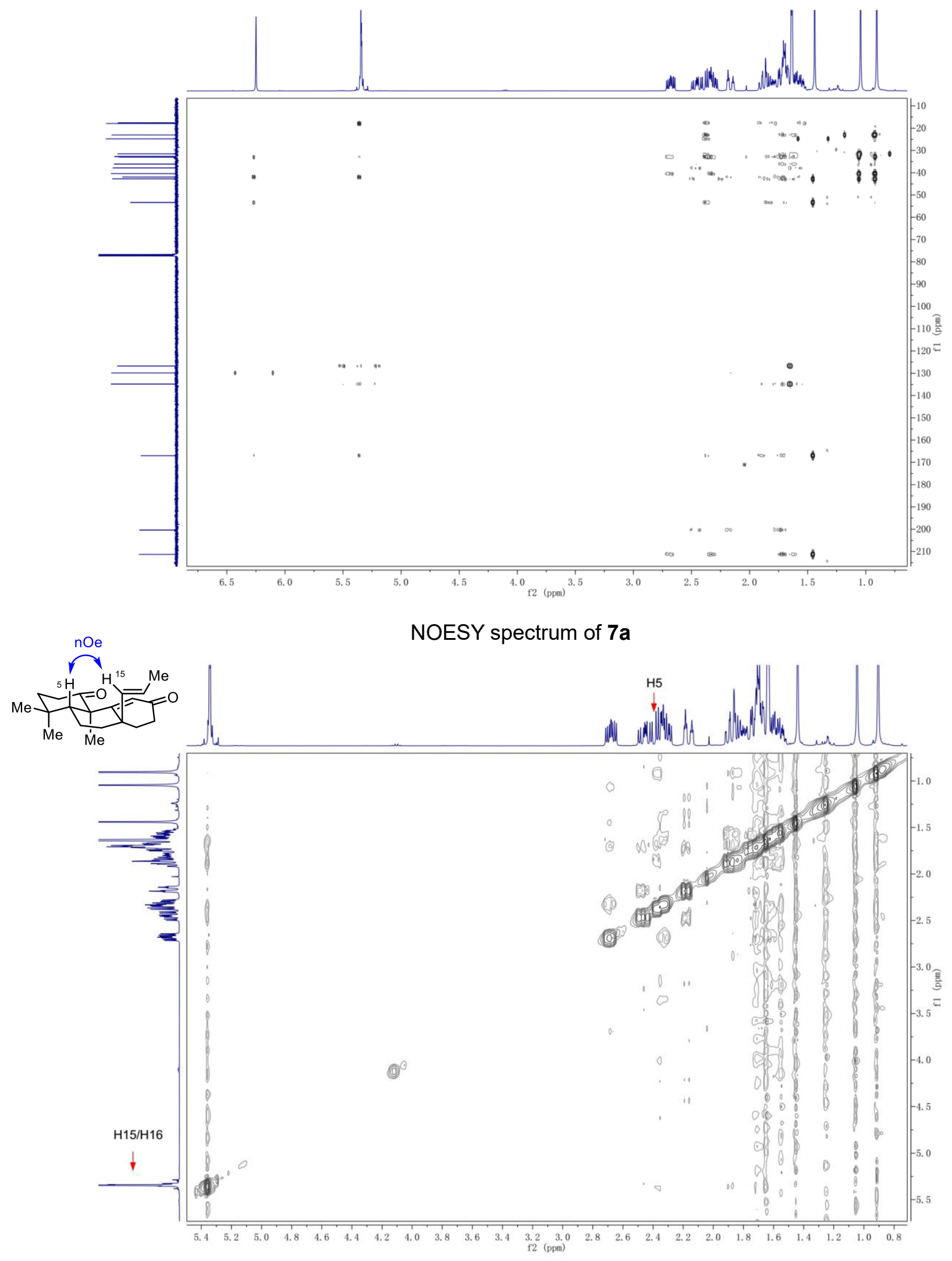

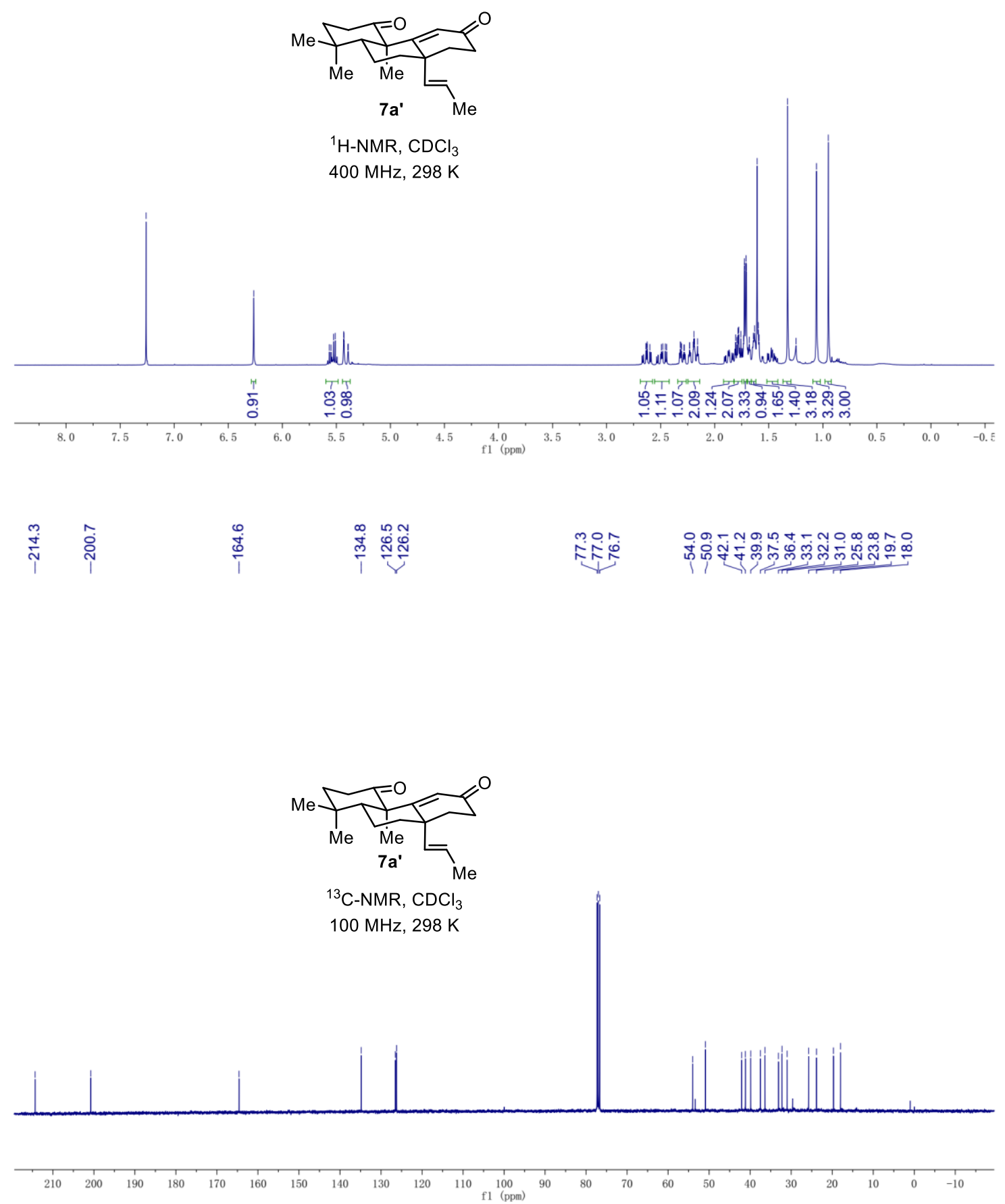


\section{${ }^{1} \mathrm{H}-{ }^{1} \mathrm{H}$ COSY spectrum of $7 \mathrm{a}^{\prime}$}

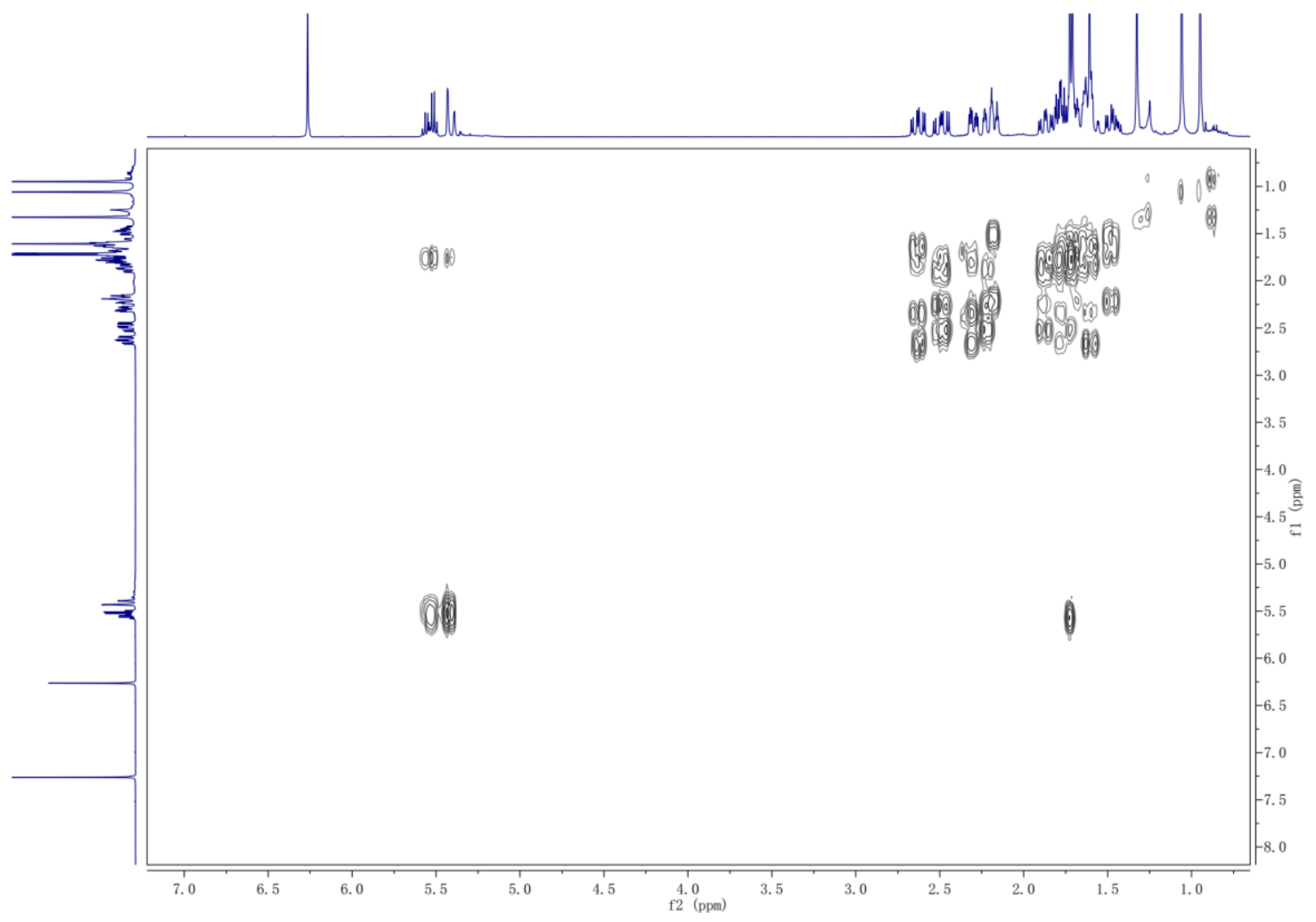

NOESY spectrum of $7 a^{\prime}$
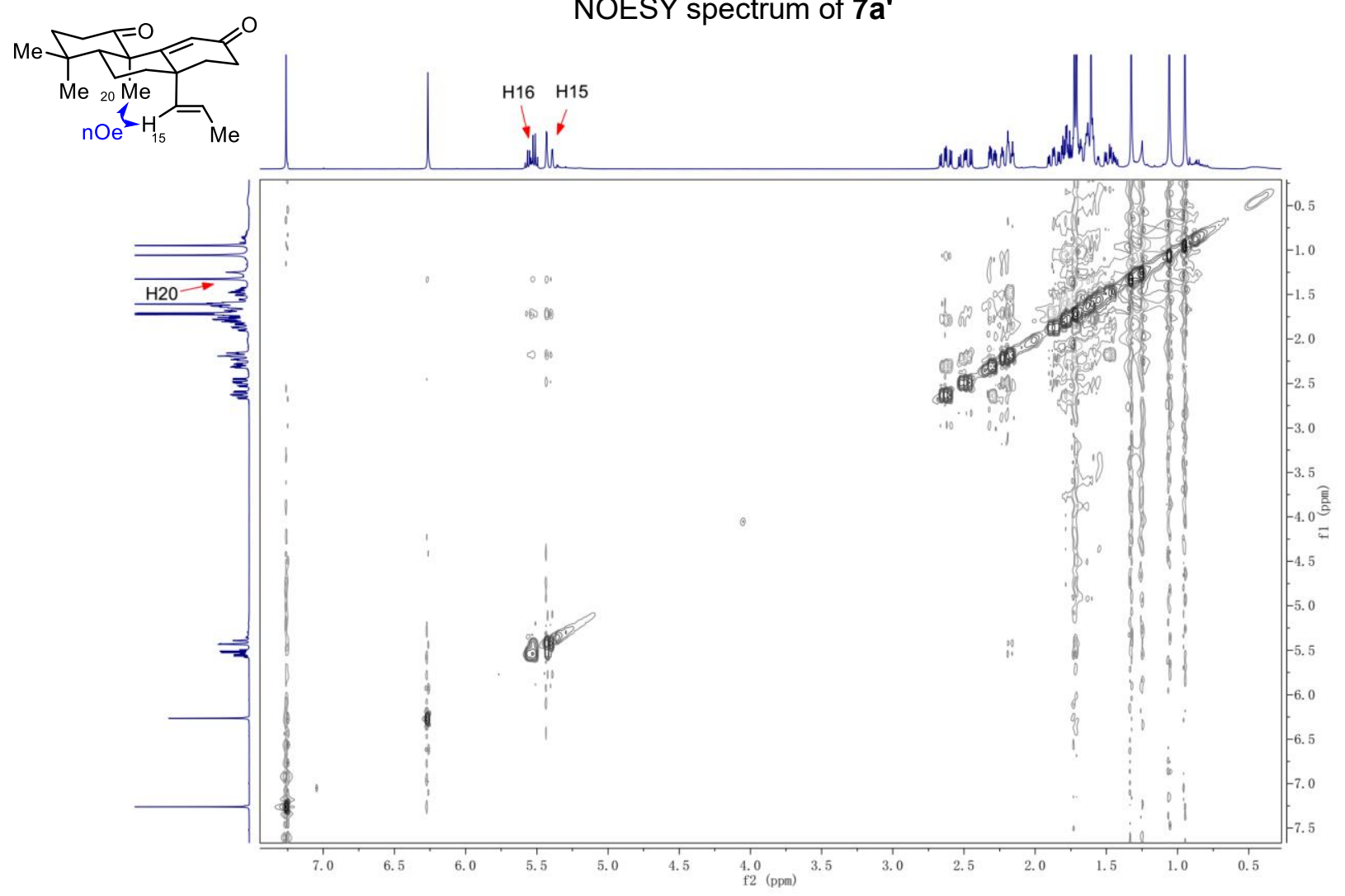
Z

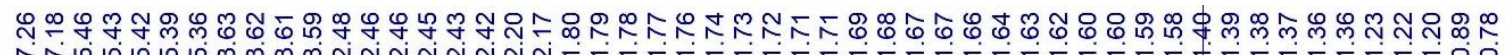

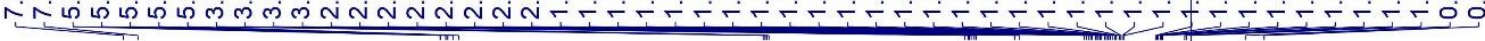
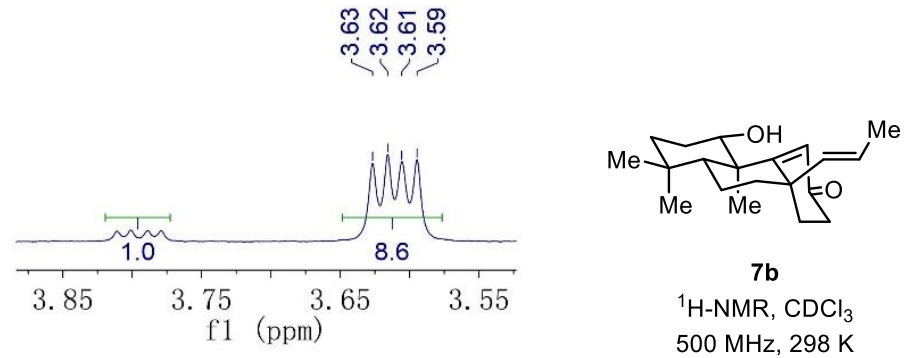

$7 b$ ${ }^{1} \mathrm{H}-\mathrm{NMR}, \mathrm{CDCl}_{3}$ $500 \mathrm{MHz}, 298 \mathrm{~K}$
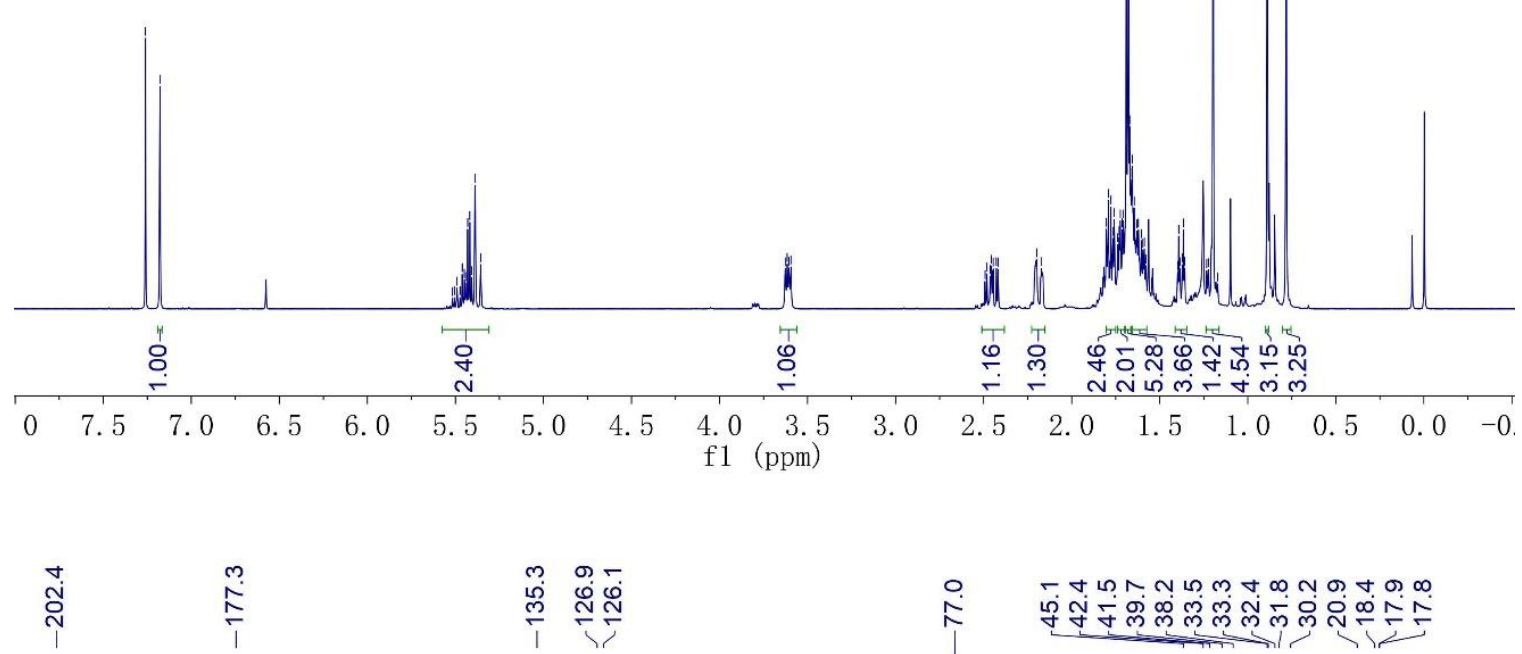

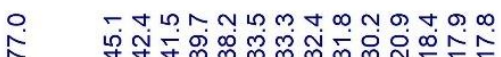

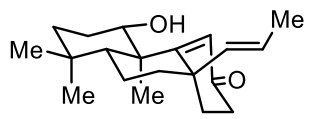

$7 b$

${ }^{13} \mathrm{C}-\mathrm{NMR}, \mathrm{CDCl}_{3}$

$125 \mathrm{MHz}, 298 \mathrm{~K}$

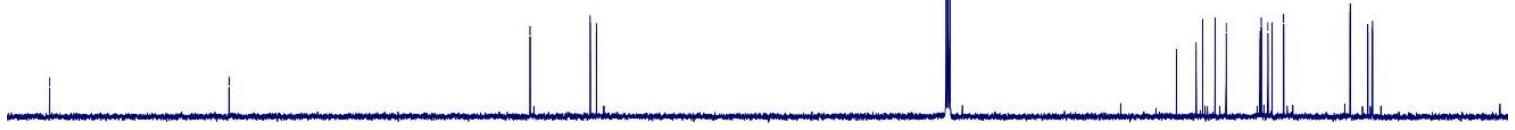

$\begin{array}{lllllllllllllllllllll}200 & 190 & 180 & 170 & 160 & 150 & 140 & 130 & 120 & \begin{array}{c}110 \\ \mathrm{f} 1\end{array} \underset{(\mathrm{ppm})}{100} & 90 & 80 & 70 & 60 & 50 & 40 & 30 & 20 & 10 & 0\end{array}$ 


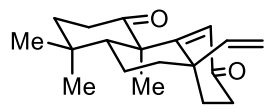

$7 \mathrm{c}$

${ }^{1} \mathrm{H}-\mathrm{NMR}, \mathrm{CDCl}_{3}$

$500 \mathrm{MHz}, 298 \mathrm{~K}$

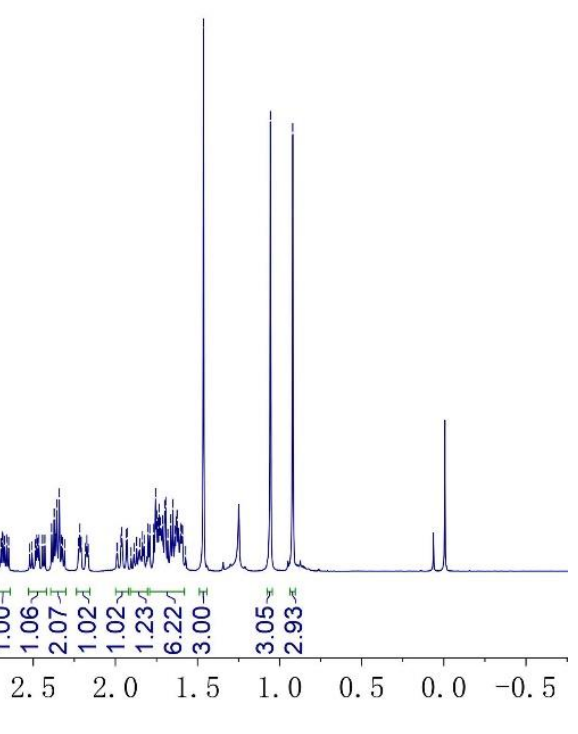

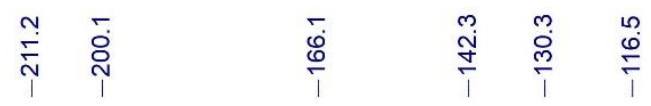

m人每古-

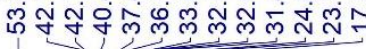

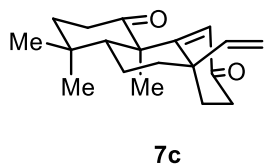

${ }^{13} \mathrm{C}-\mathrm{NMR}, \mathrm{CDCl}_{3}$

$125 \mathrm{MHz}, 298 \mathrm{~K}$

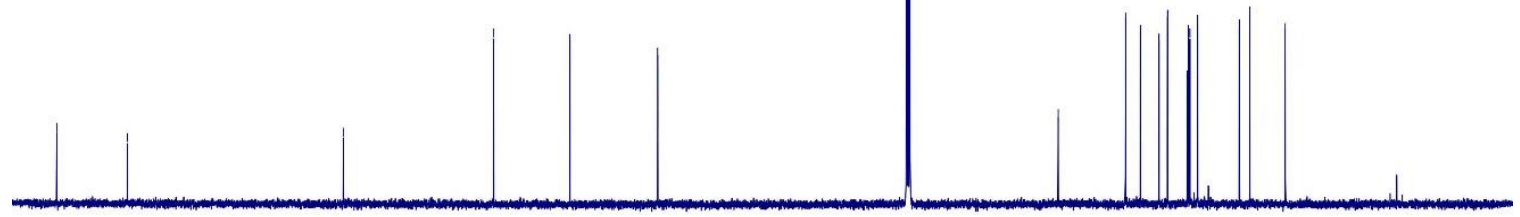

$\begin{array}{lllllllllllllllllllllll}210 & 200 & 190 & 180 & 170 & 160 & 150 & 140 & 130 & 120 & 110 & 100 & 90 & 80 & 70 & 60 & 50 & 40 & 30 & 20 & 10 & 0 & -10\end{array}$ 


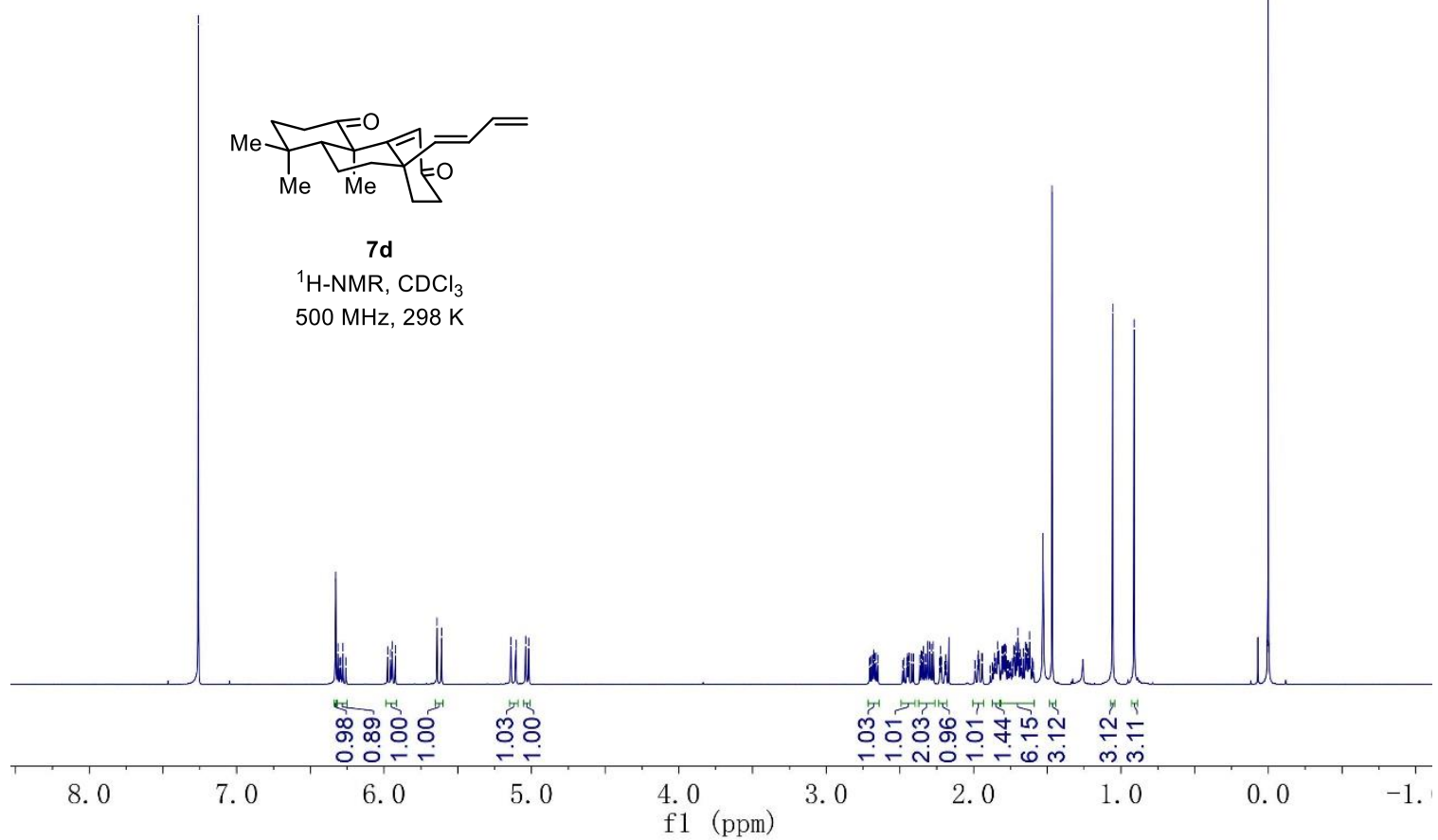

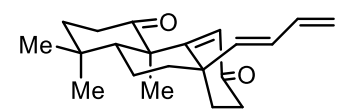

7d

${ }^{13} \mathrm{C}-\mathrm{NMR}, \mathrm{CDCl}_{3}$ $125 \mathrm{MHz}, 298 \mathrm{~K}$

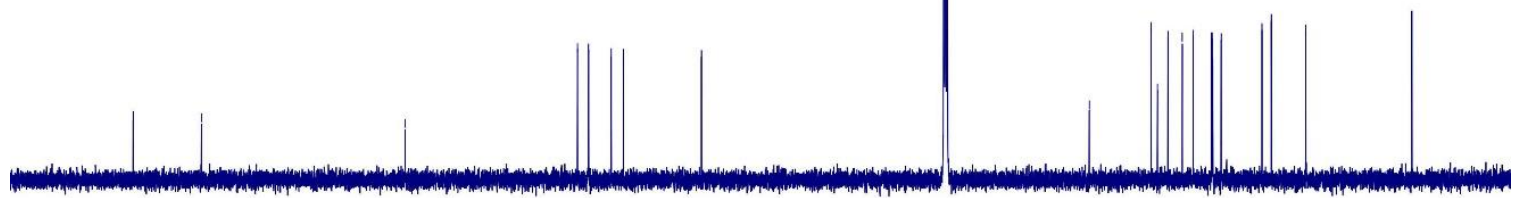

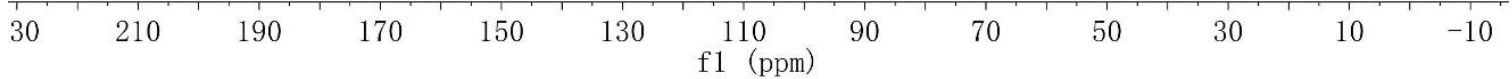




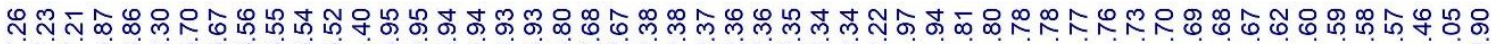

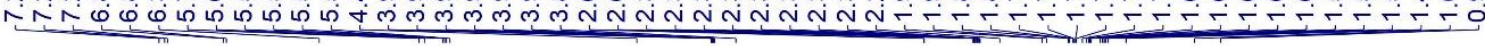

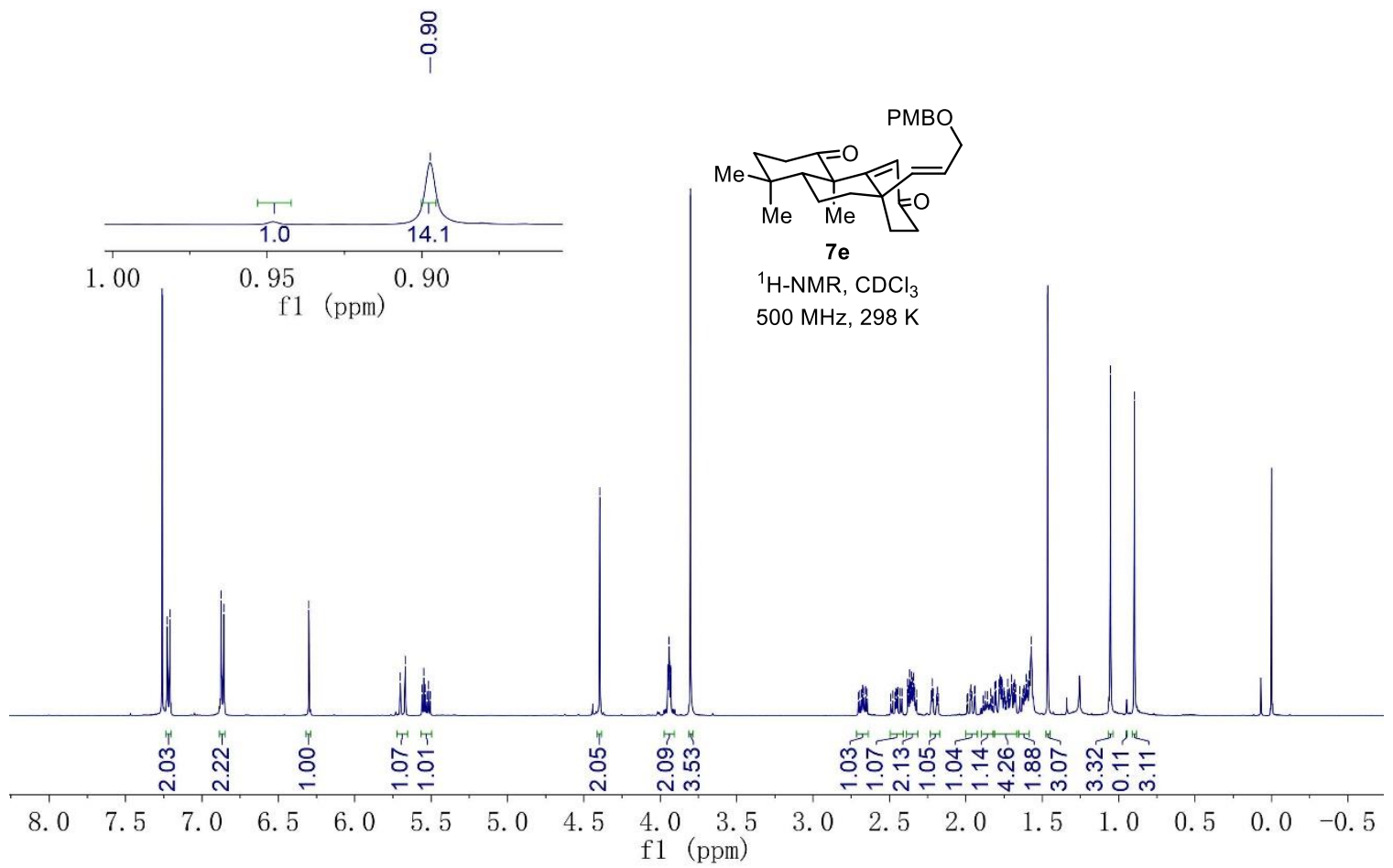

ㄱ.

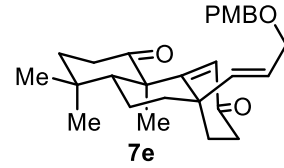

${ }^{13} \mathrm{C}-\mathrm{NMR}, \mathrm{CDCl}_{3}$

$125 \mathrm{MHz}, 298 \mathrm{~K}$

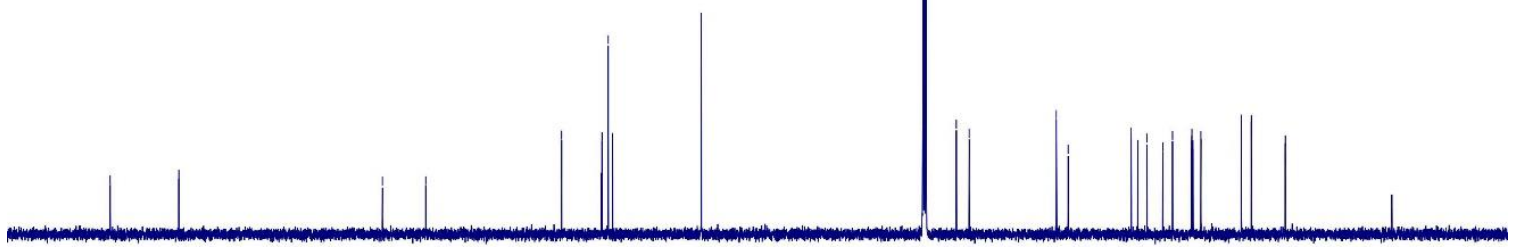

$\begin{array}{llllllllllllllllllllllll}220 & 210 & 200 & 190 & 180 & 170 & 160 & 150 & 140 & 130 & 120 & 110 & 100 & 90 & 80 & 70 & 60 & 50 & 40 & 30 & 20 & 10 & 0 & -10\end{array}$ f1 (ppm) 


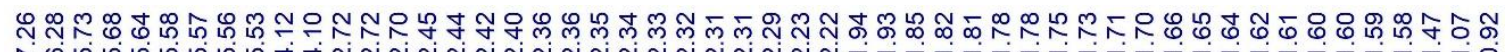

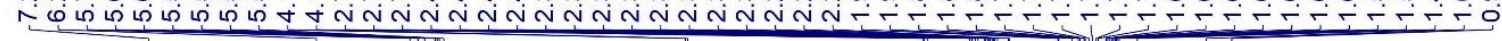
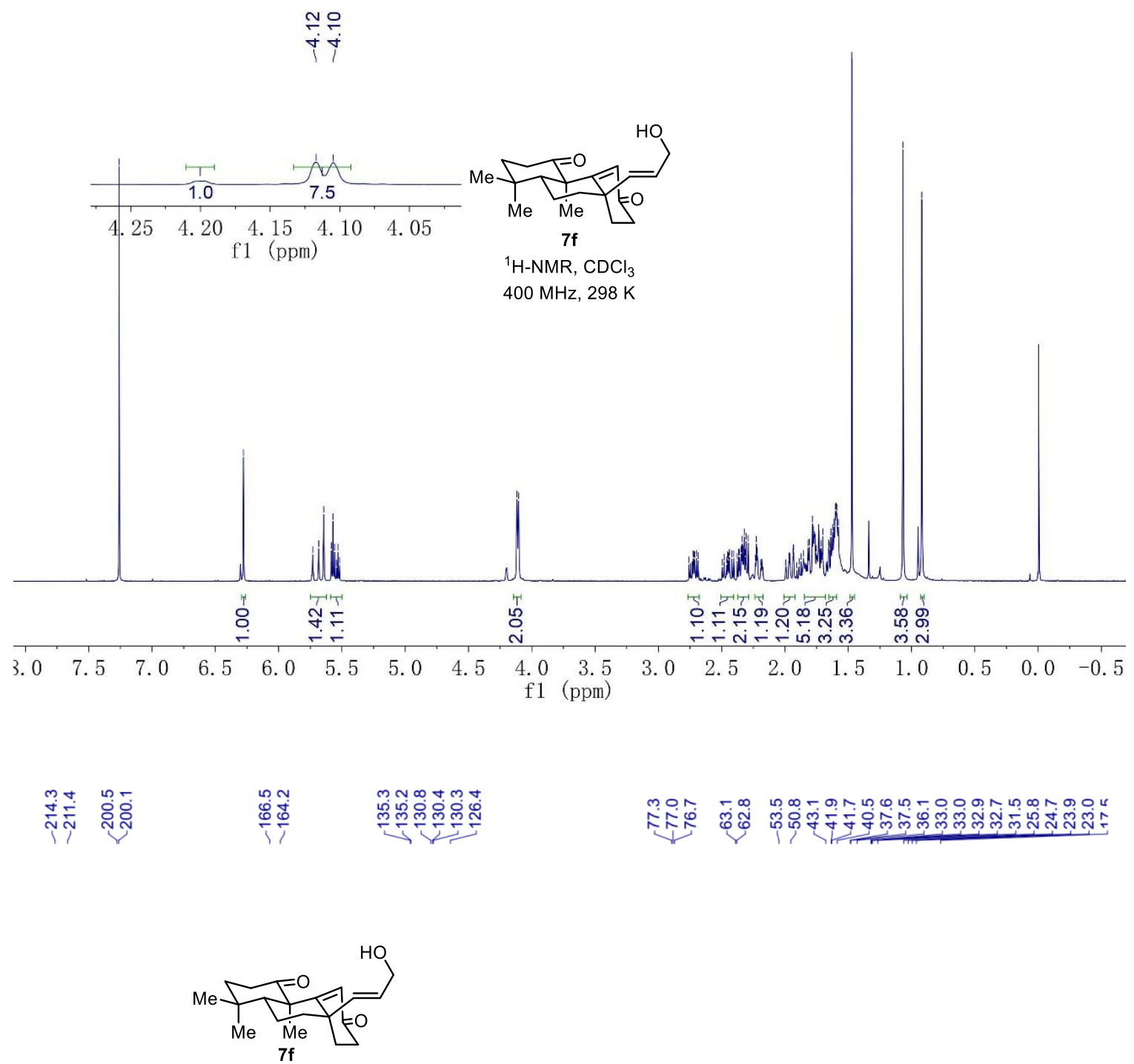

${ }^{13} \mathrm{C}-\mathrm{NMR}, \mathrm{CDCl}_{3}$

$100 \mathrm{MHz}, 298 \mathrm{~K}$
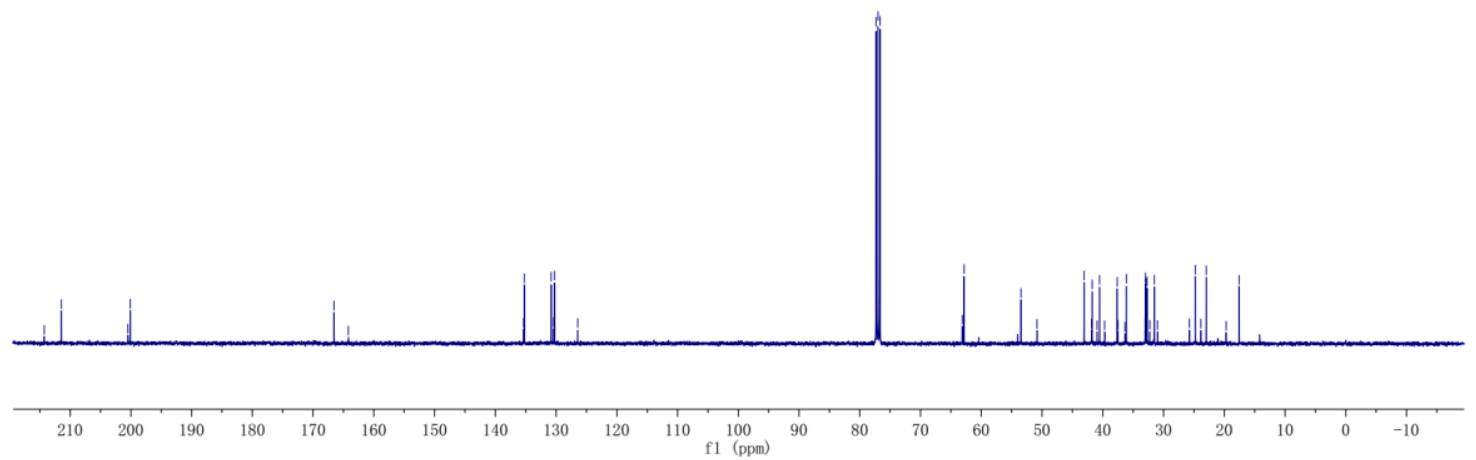
ํำฺ

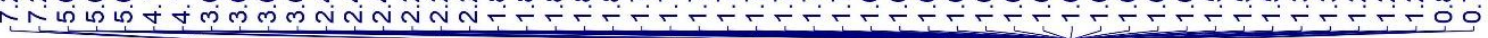
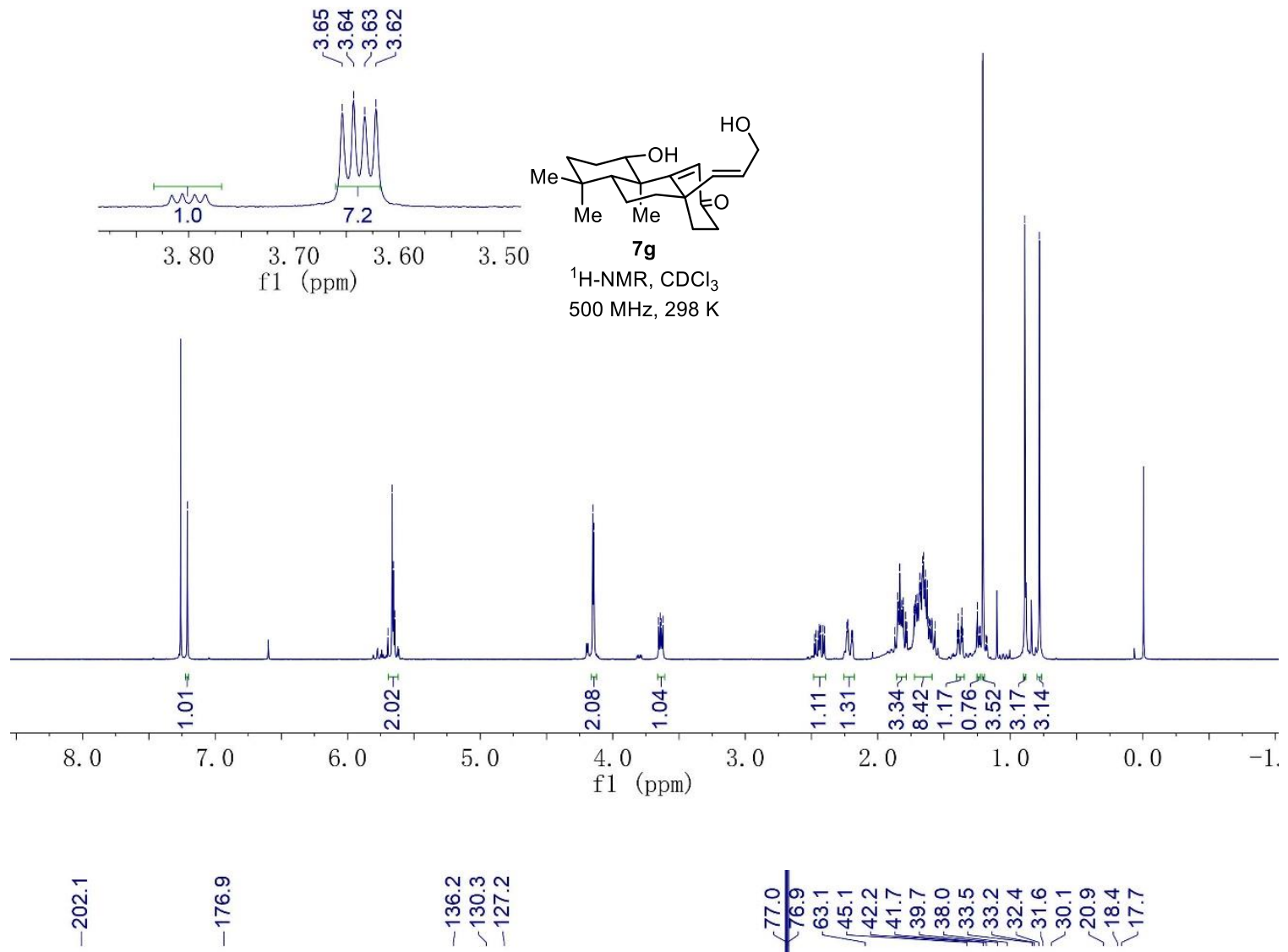

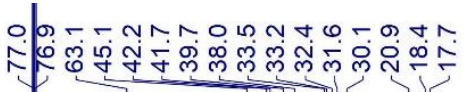

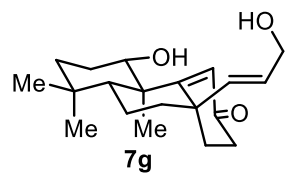

${ }^{13} \mathrm{C}-\mathrm{NMR}, \mathrm{CDCl}_{3}$

$125 \mathrm{MHz}, 298 \mathrm{~K}$

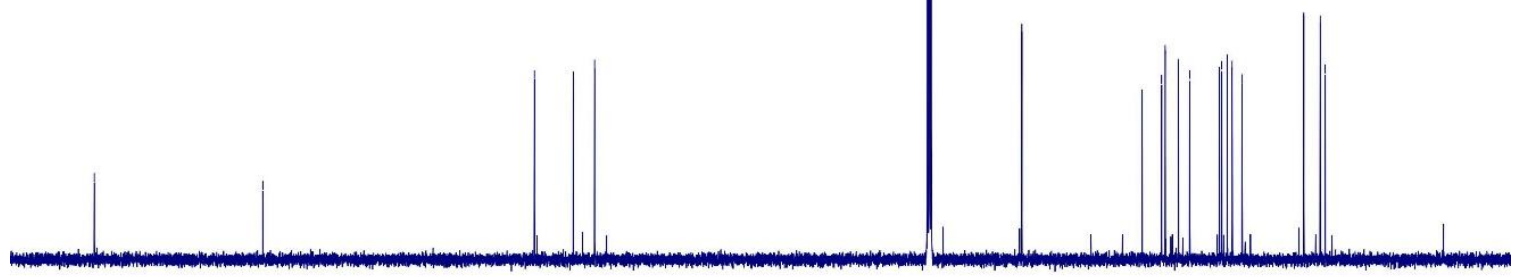

$\begin{array}{lllllllllllllllllllllll}210 & 200 & 190 & 180 & 170 & 160 & 150 & 140 & 130 & 120 & 110 & \begin{array}{l}100 \\ \mathrm{f} 1\end{array}(\mathrm{ppm})\end{array}$ 

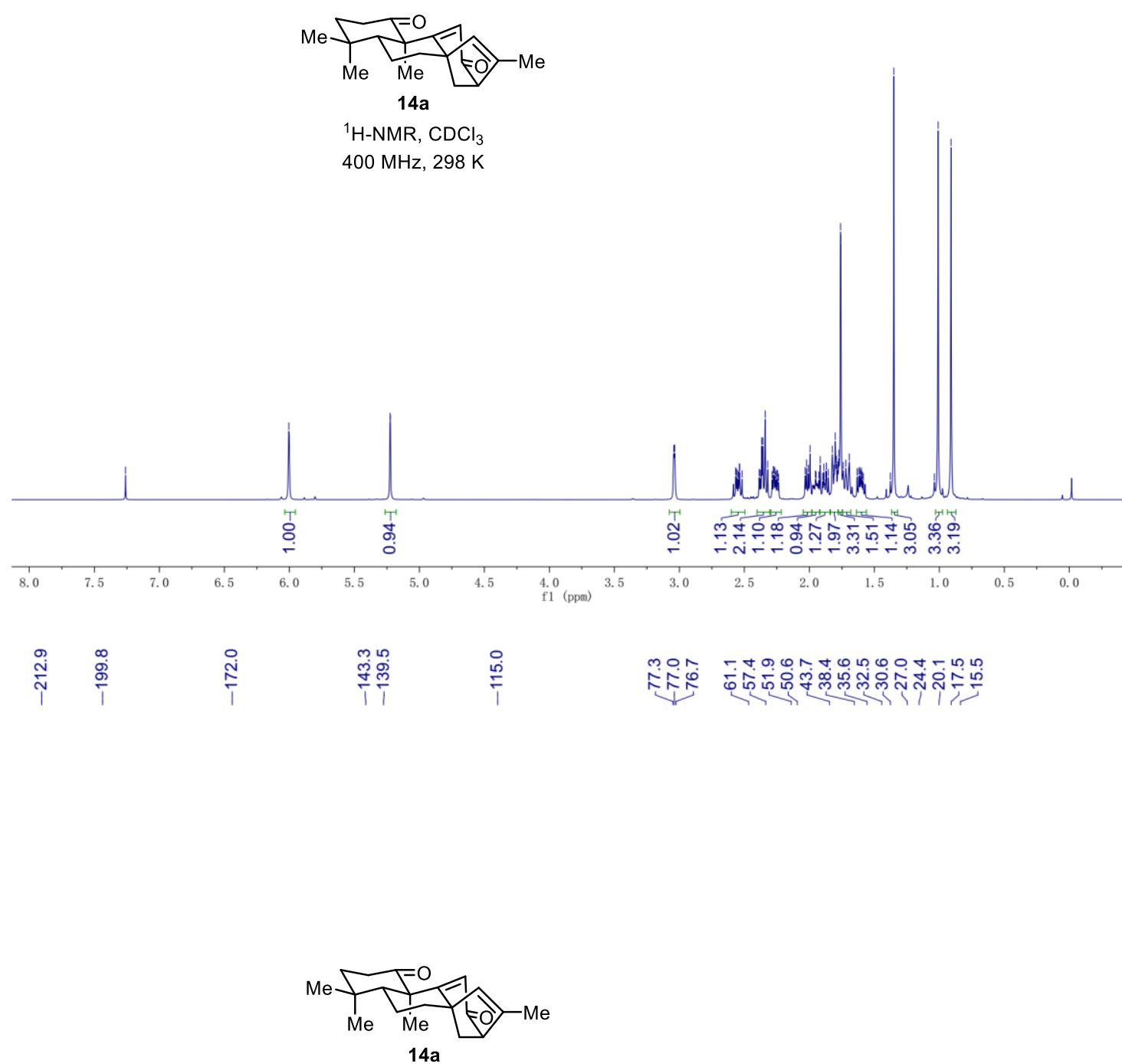

${ }^{13} \mathrm{C}-\mathrm{NMR}, \mathrm{CDCl}_{3}$ $100 \mathrm{MHz}, 298 \mathrm{~K}$

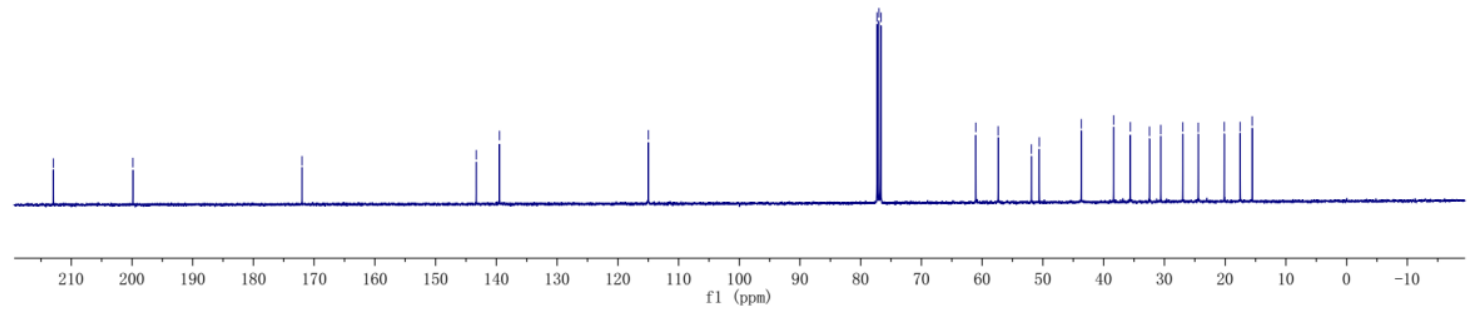




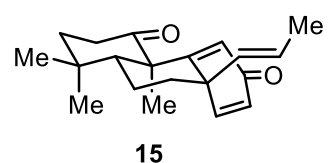

${ }^{1} \mathrm{H}-\mathrm{NMR}, \mathrm{CDCl}_{3}$

$400 \mathrm{MHz}, 298 \mathrm{~K}$

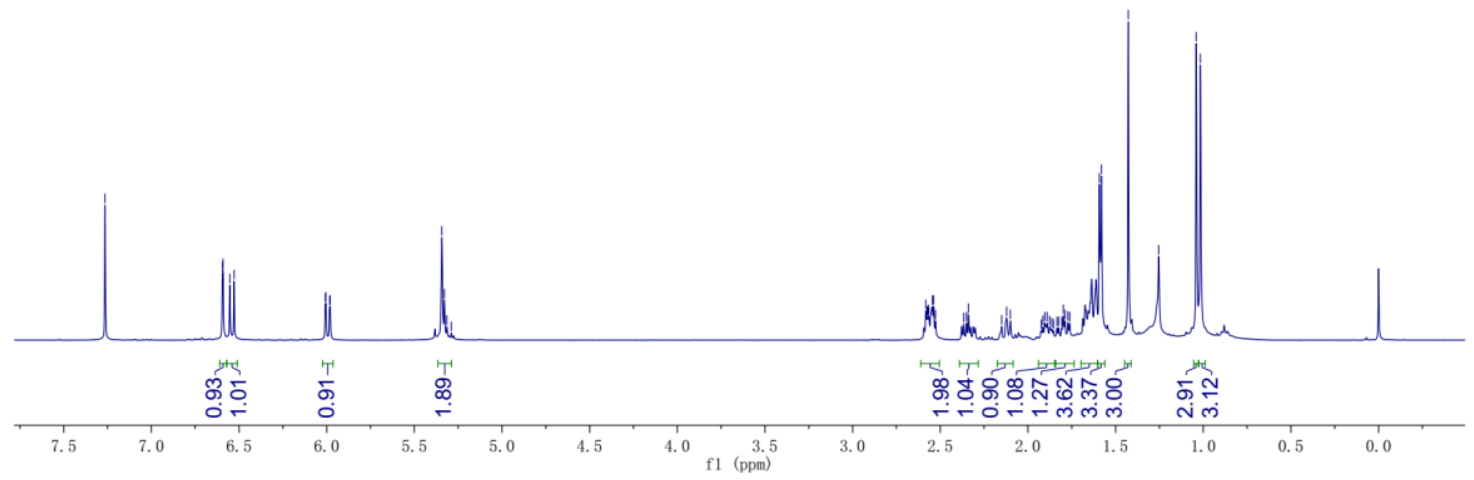

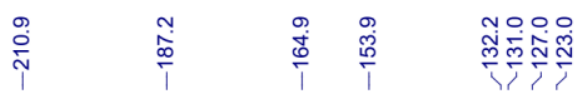
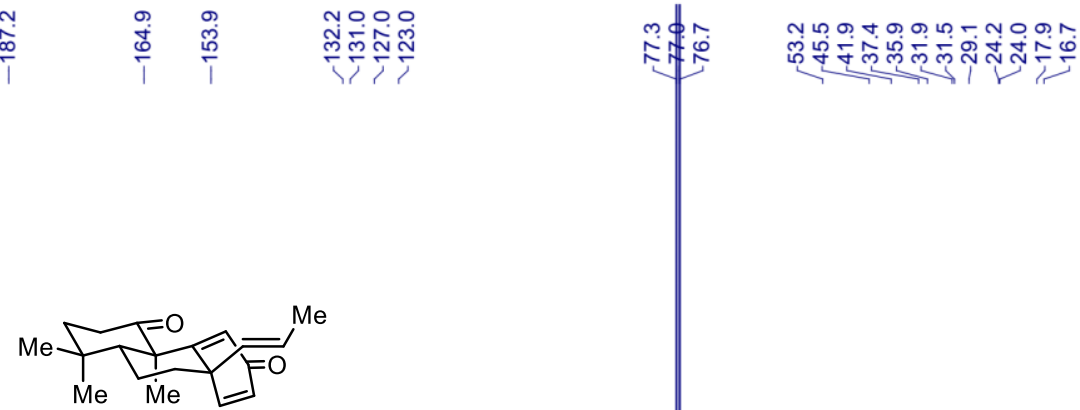

15

${ }^{13} \mathrm{C}-\mathrm{NMR}, \mathrm{CDCl}_{3}$ $100 \mathrm{MHz}, 298 \mathrm{~K}$

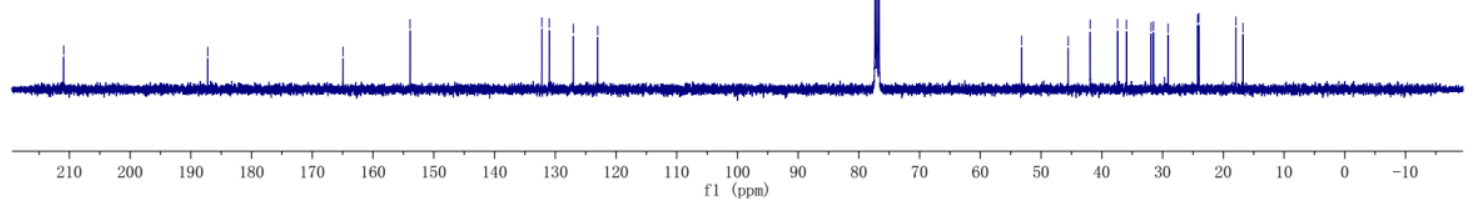




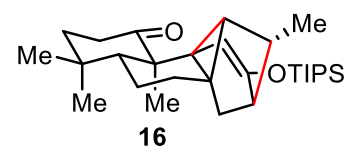

${ }^{1} \mathrm{H}-\mathrm{NMR}, \mathrm{CDCl}_{3}$

$600 \mathrm{MHz}, 298 \mathrm{~K}$

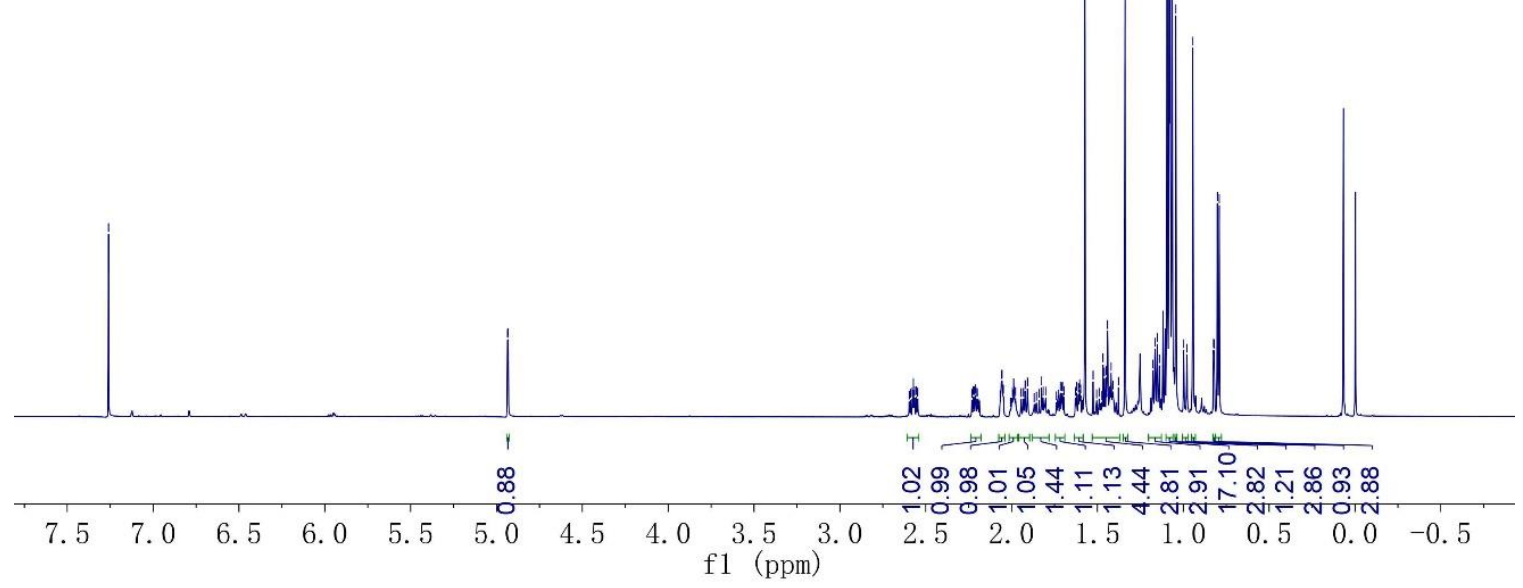

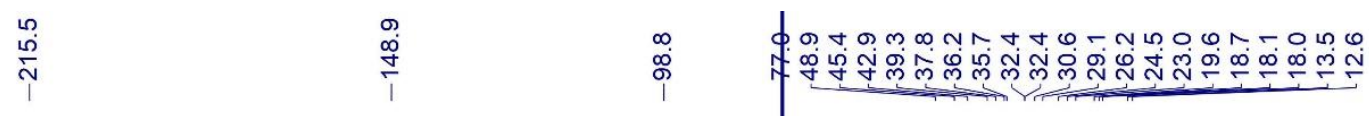

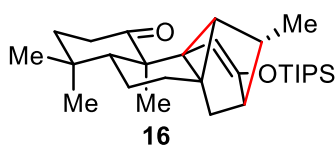

${ }^{13} \mathrm{C}-\mathrm{NMR}, \mathrm{CDCl}_{3}$

$150 \mathrm{MHz}, 298 \mathrm{~K}$

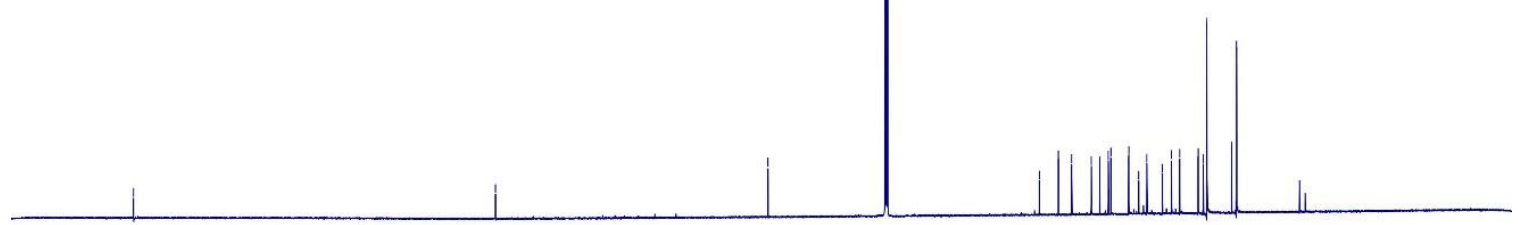

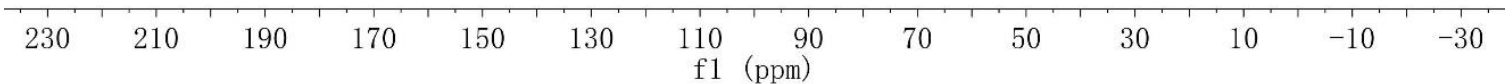




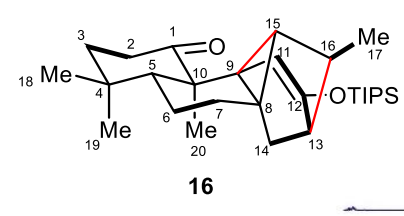

${ }^{1} \mathrm{H}-{ }^{1} \mathrm{H}$ COSY spectrum of 16

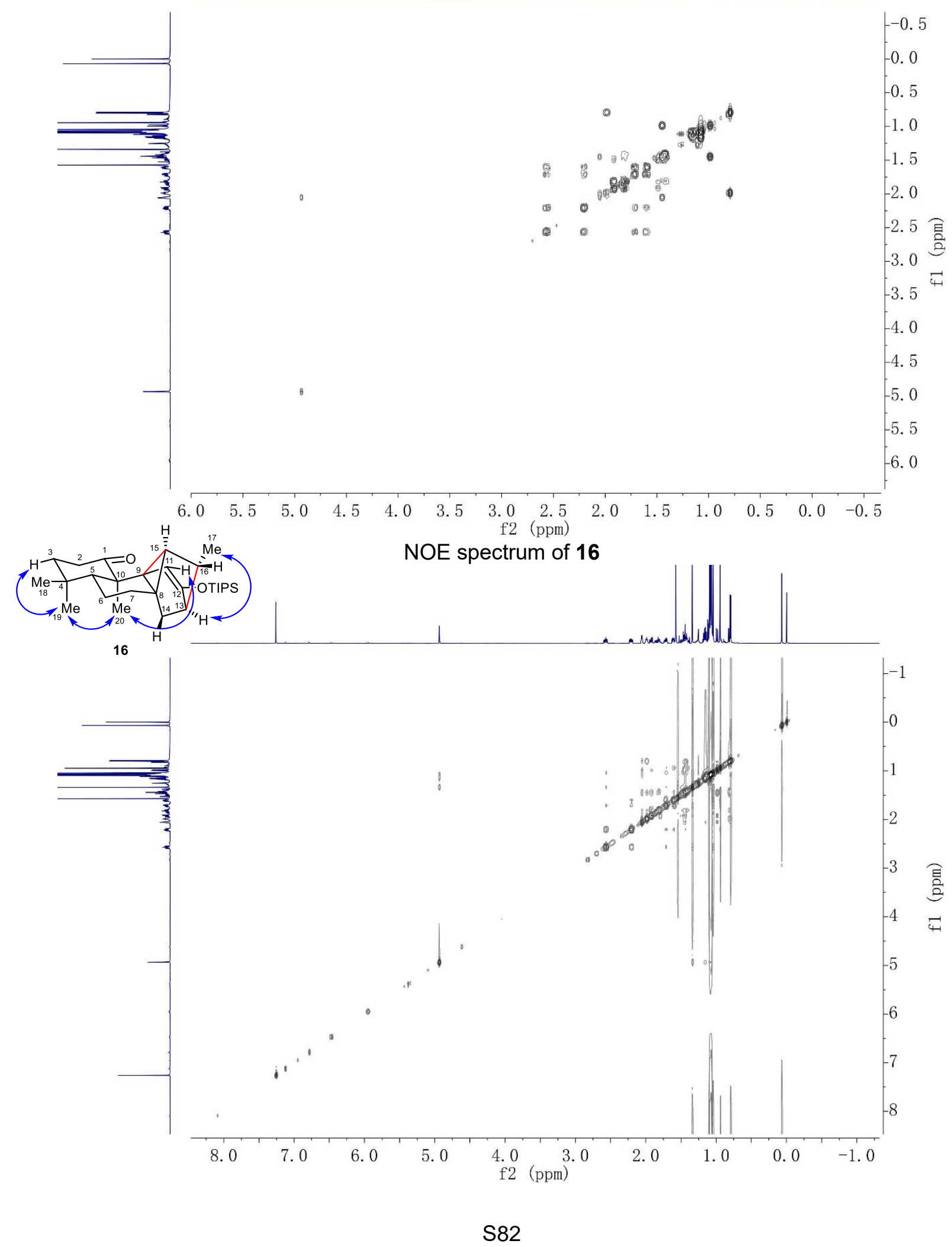



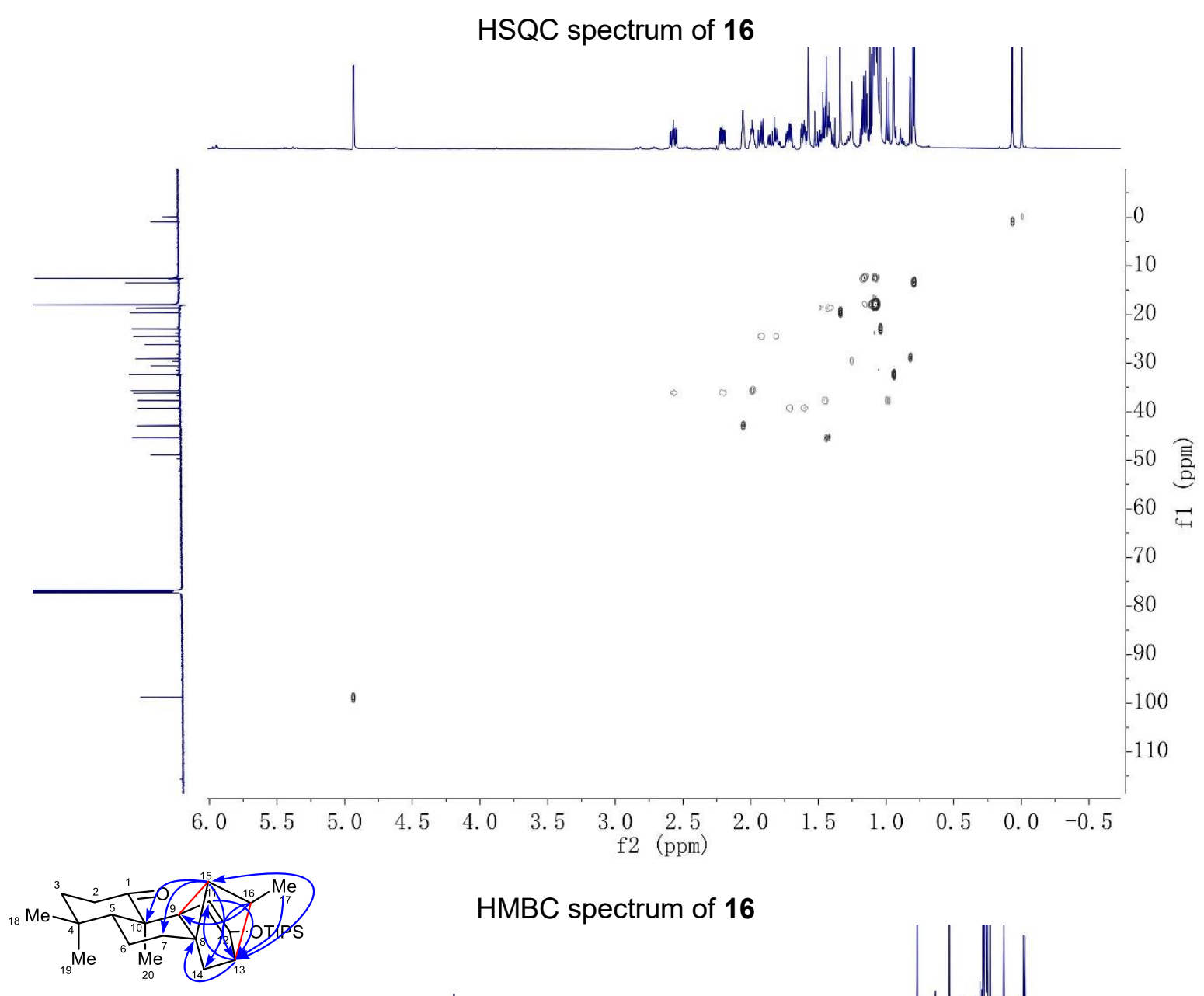

\section{HMBC spectrum of 16}

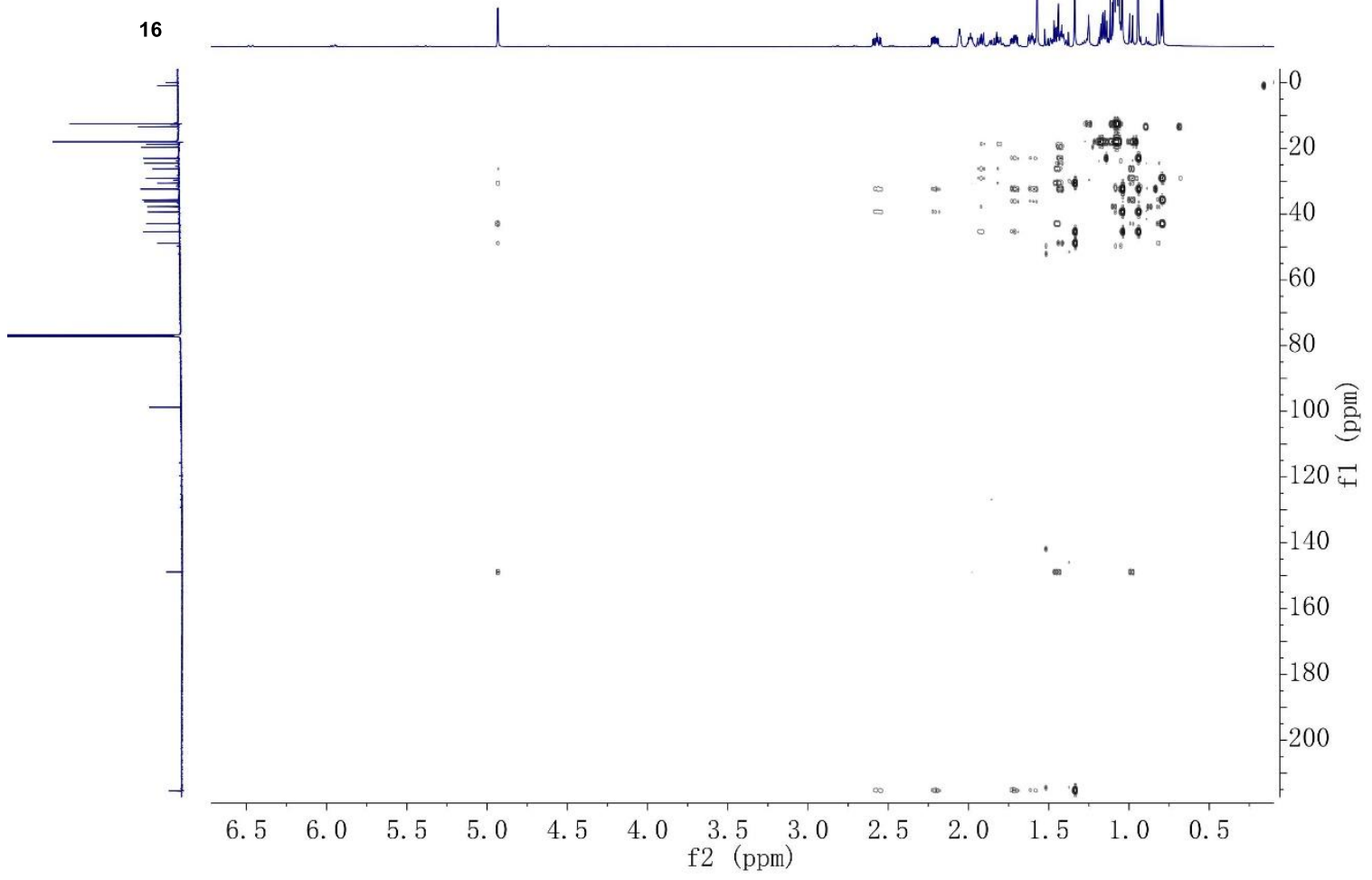




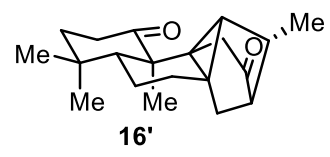

${ }^{1} \mathrm{H}-\mathrm{NMR}, \mathrm{CDCl}_{3}$ $500 \mathrm{MHz}, 298 \mathrm{~K}$

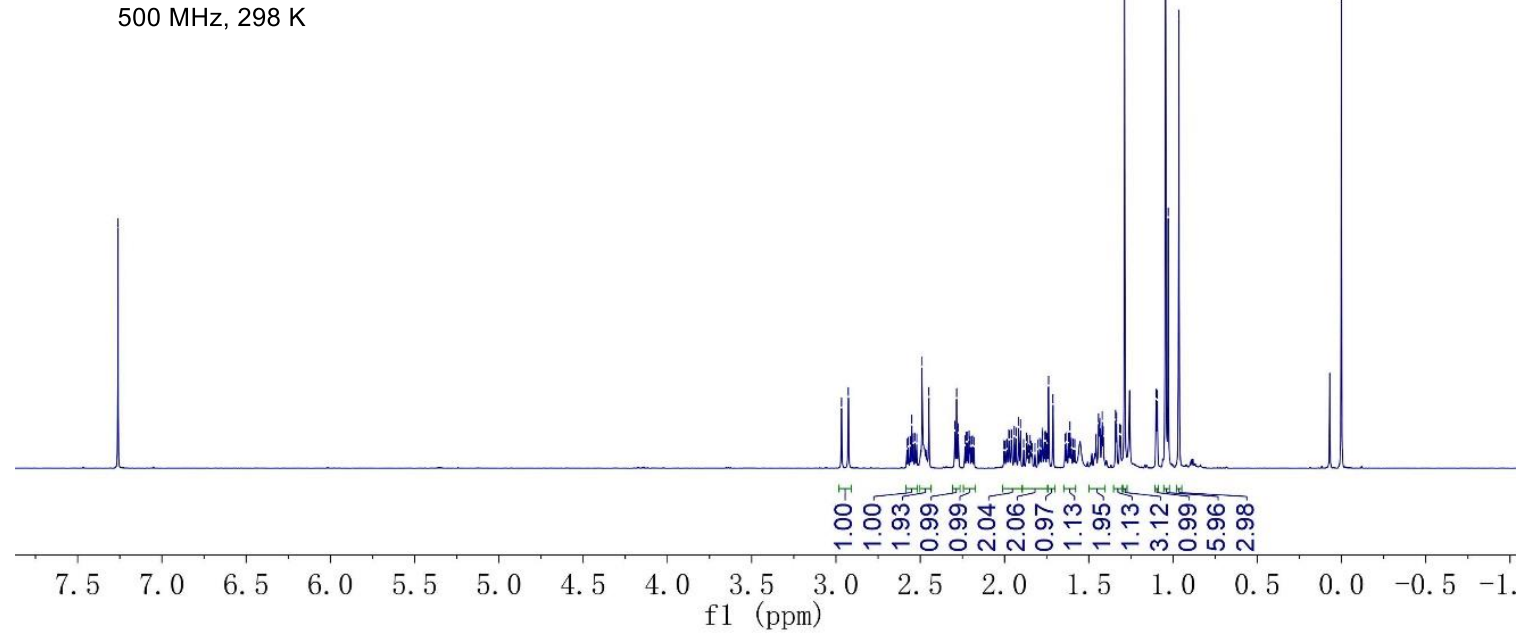

$\stackrel{\text { กิำ }}{\stackrel{n}{N}}$

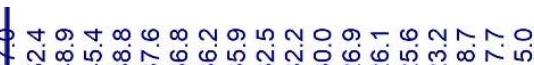

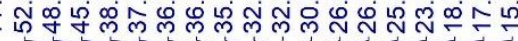

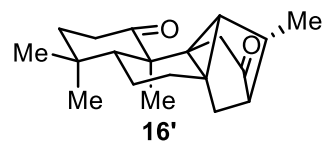

${ }^{13} \mathrm{C}-\mathrm{NMR}, \mathrm{CDCl}_{3}$

$126 \mathrm{MHz}, 298 \mathrm{~K}$

$\begin{array}{rlllllllllllllllllllllll}220 & 210 & 200 & 190 & 180 & 170 & 160 & 150 & 140 & 130 & 120 & 110 & 100 & 90 & 80 & 70 & 60 & 50 & 40 & 30 & 20 & 10 & 0 & -1( \\ \mathrm{f} 1 & (\mathrm{ppm})\end{array}$ 


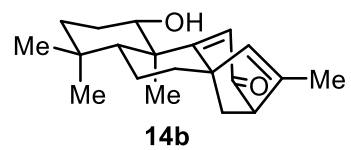

${ }^{1} \mathrm{H}-\mathrm{NMR}, \mathrm{CDCl}_{3}$

$500 \mathrm{MHz}, 298 \mathrm{~K}$
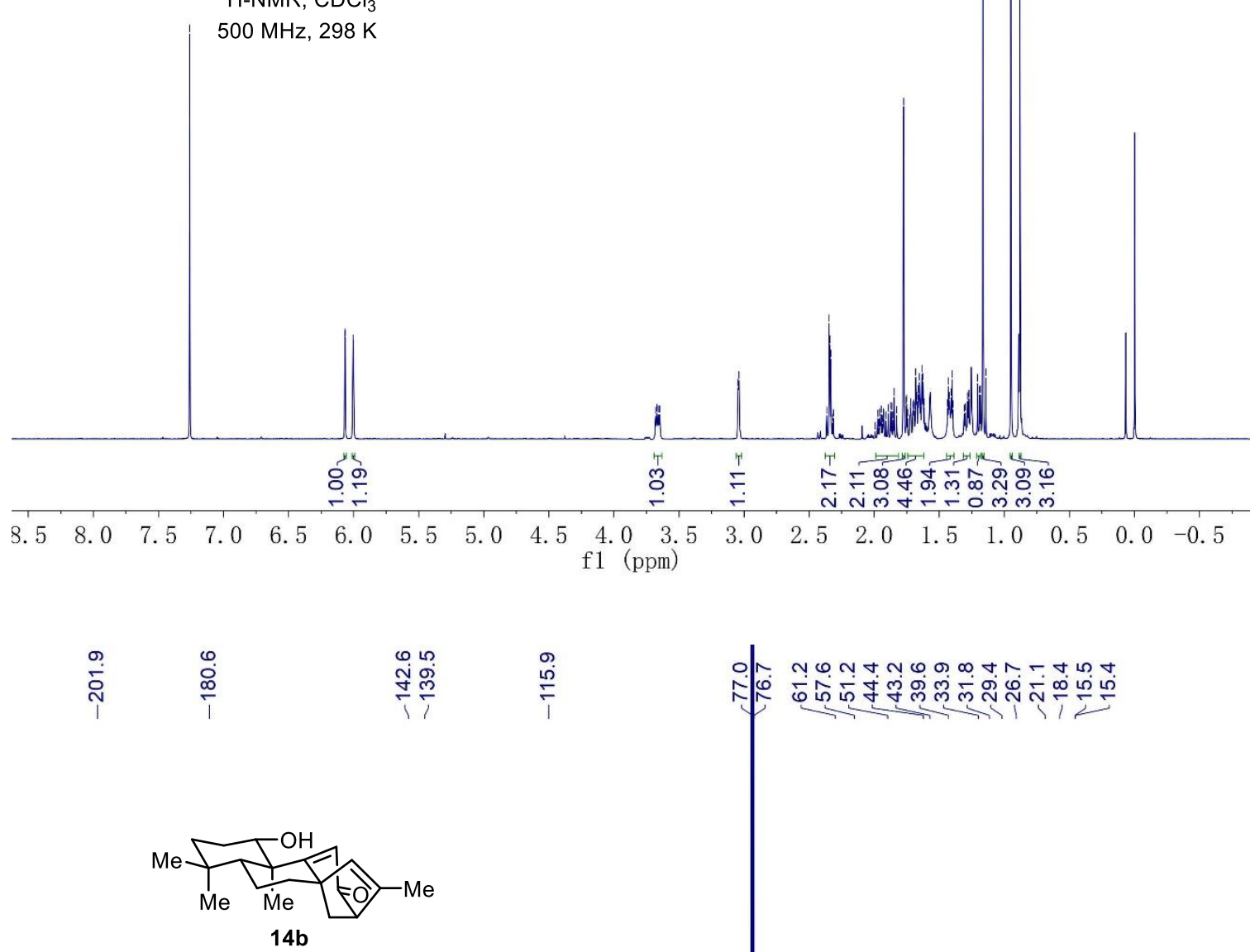

${ }^{13} \mathrm{C}-\mathrm{NMR}, \mathrm{CDCl}_{3}$

$126 \mathrm{MHz}, 298 \mathrm{~K}$

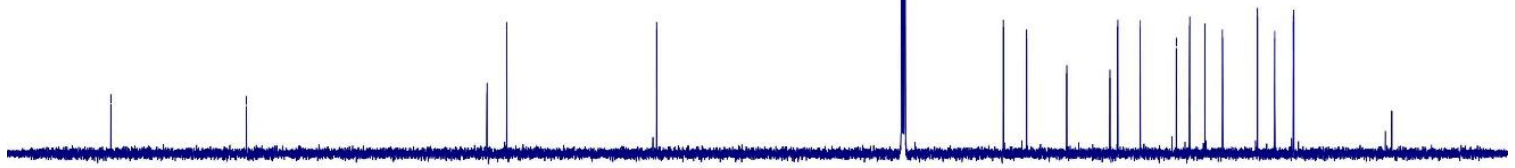

$\begin{array}{lllllllllllllllllllllll}210 & 200 & 190 & 180 & 170 & 160 & 150 & 140 & 130 & 120 & 110 & 100 & 90 & 80 & 70 & 60 & 50 & 40 & 30 & 20 & 10 & 0 & -10\end{array}$ 


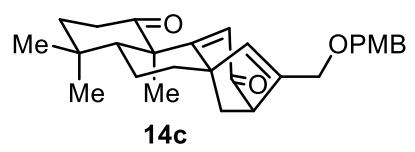

${ }^{1} \mathrm{H}-\mathrm{NMR}, \mathrm{CDCl}_{3}$

$500 \mathrm{MHz}, 298 \mathrm{~K}$
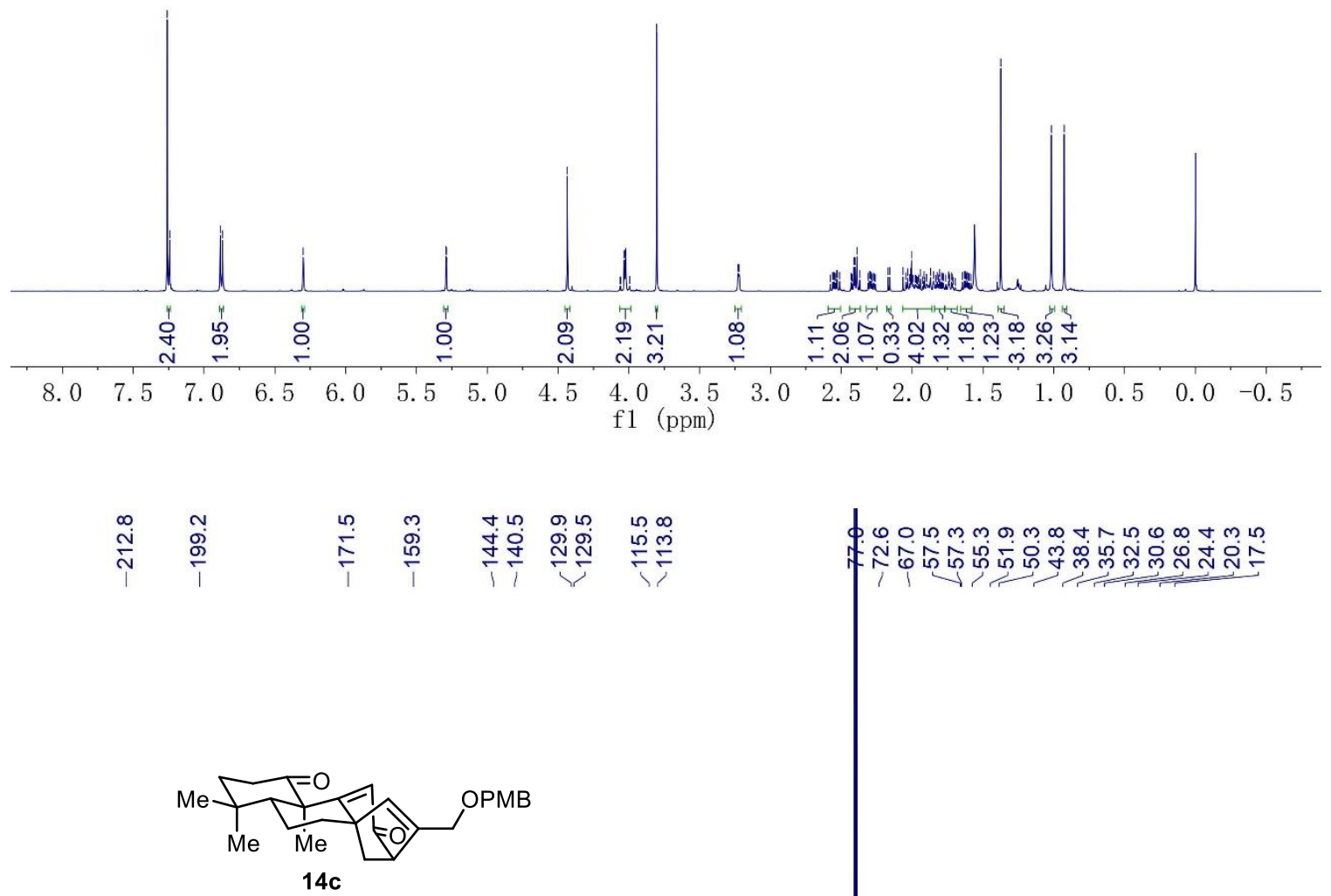

${ }^{13} \mathrm{C}-\mathrm{NMR}, \mathrm{CDCl}_{3}$

$126 \mathrm{MHz}, 298 \mathrm{~K}$

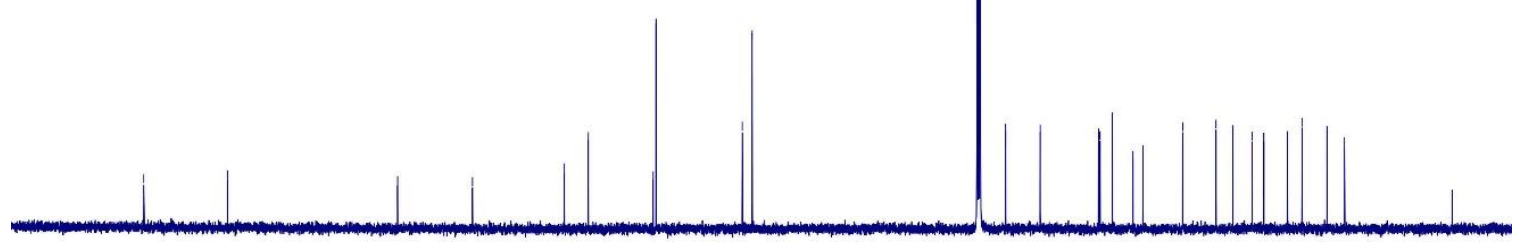

$\begin{array}{lllllllllllllllllllllllll}230 & 220 & 210 & 200 & 190 & 180 & 170 & 160 & 150 & 140 & 130 & 120 & 110 & 100 & 90 & 80 & 70 & 60 & 50 & 40 & 30 & 20 & 10 & 0\end{array}$ 


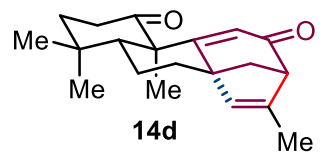

${ }^{1} \mathrm{H}-\mathrm{NMR}, \mathrm{CDCl}_{3}$

$500 \mathrm{MHz}, 298 \mathrm{~K}$
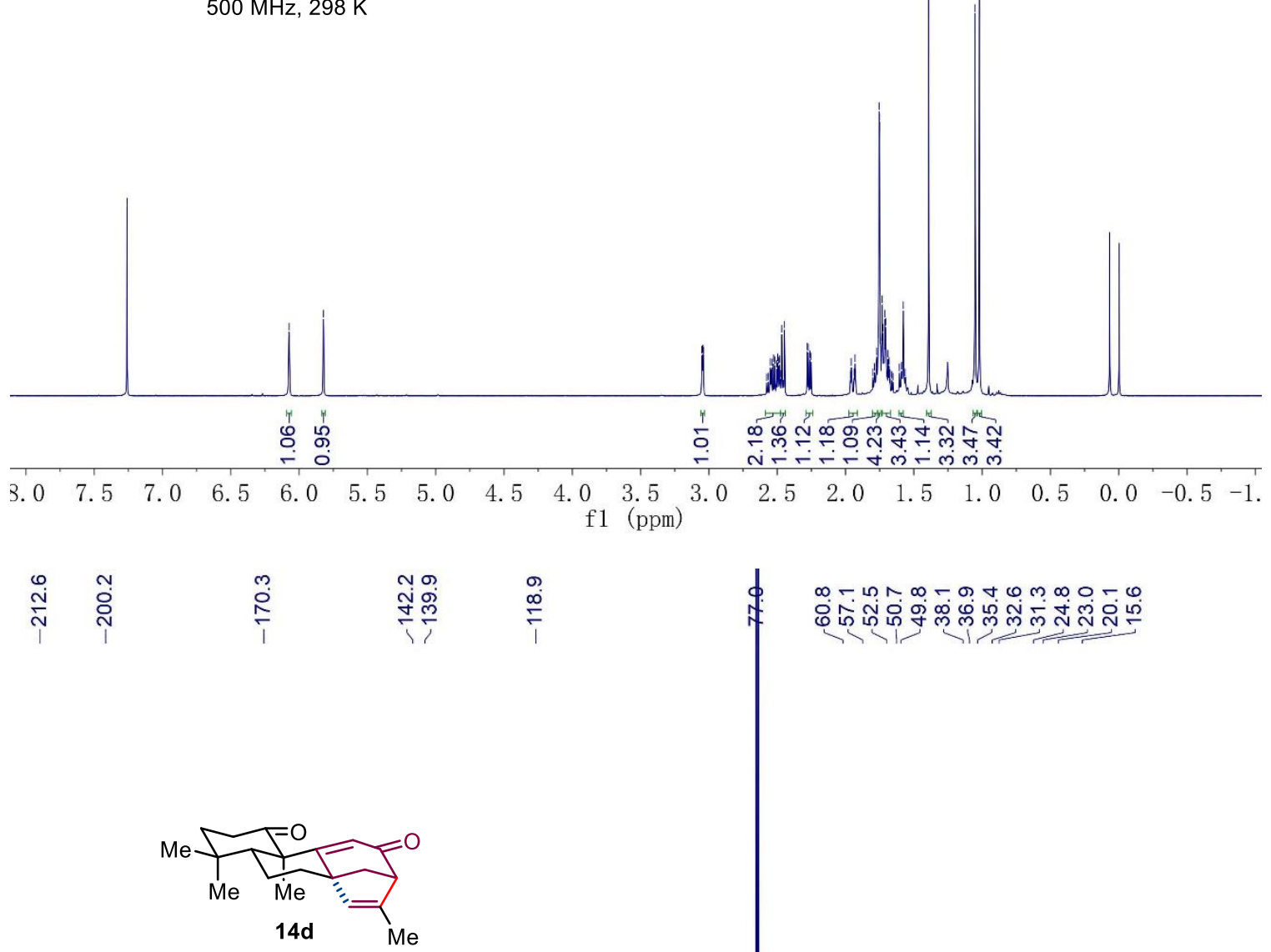

${ }^{13} \mathrm{C}-\mathrm{NMR}, \mathrm{CDCl}_{3}$

$126 \mathrm{MHz}, 298 \mathrm{~K}$

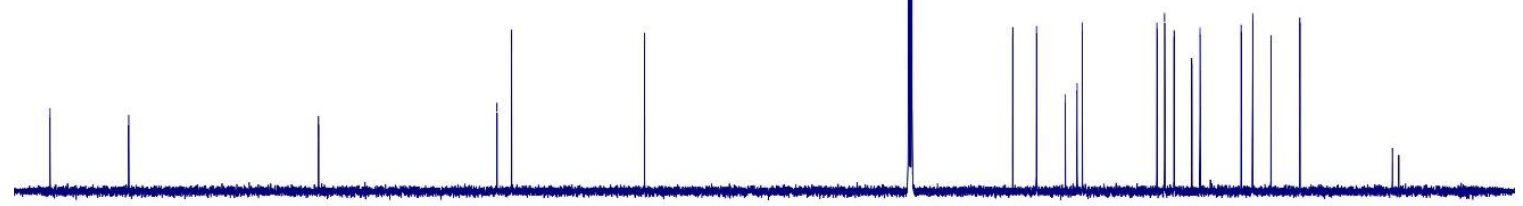

$\begin{array}{lllllllllllllllllllllll}210 & 200 & 190 & 180 & 170 & 160 & 150 & 140 & 130 & 120 & 110 & 100 & 90 & 80 & 70 & 60 & 50 & 40 & 30 & 20 & 10 & 0 & -10\end{array}$ 


\section{${ }^{1} \mathrm{H}-{ }^{1} \mathrm{H}$ COSY spectrum of $\mathbf{1 4 d}$}
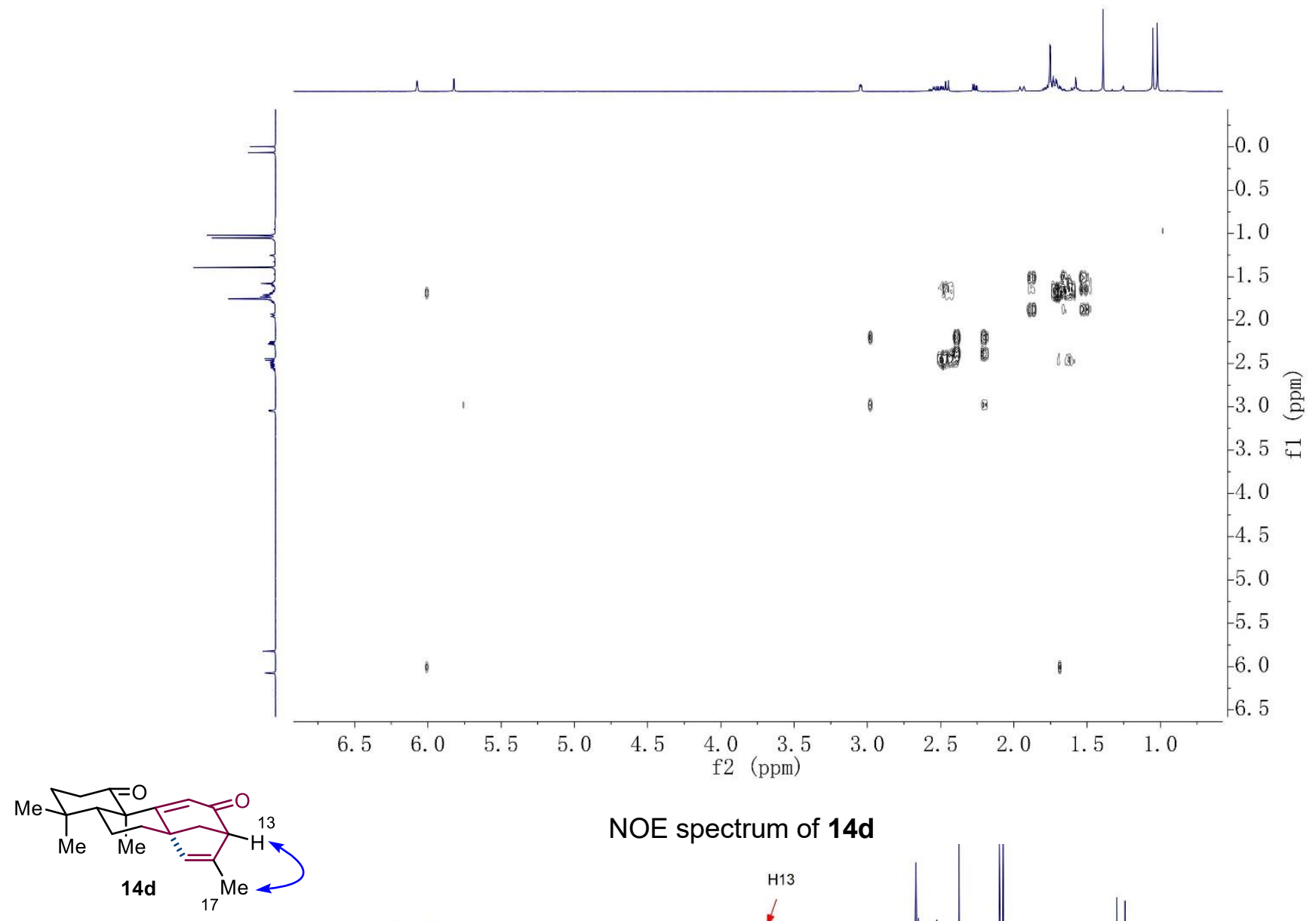

NOE spectrum of $\mathbf{1 4 d}$

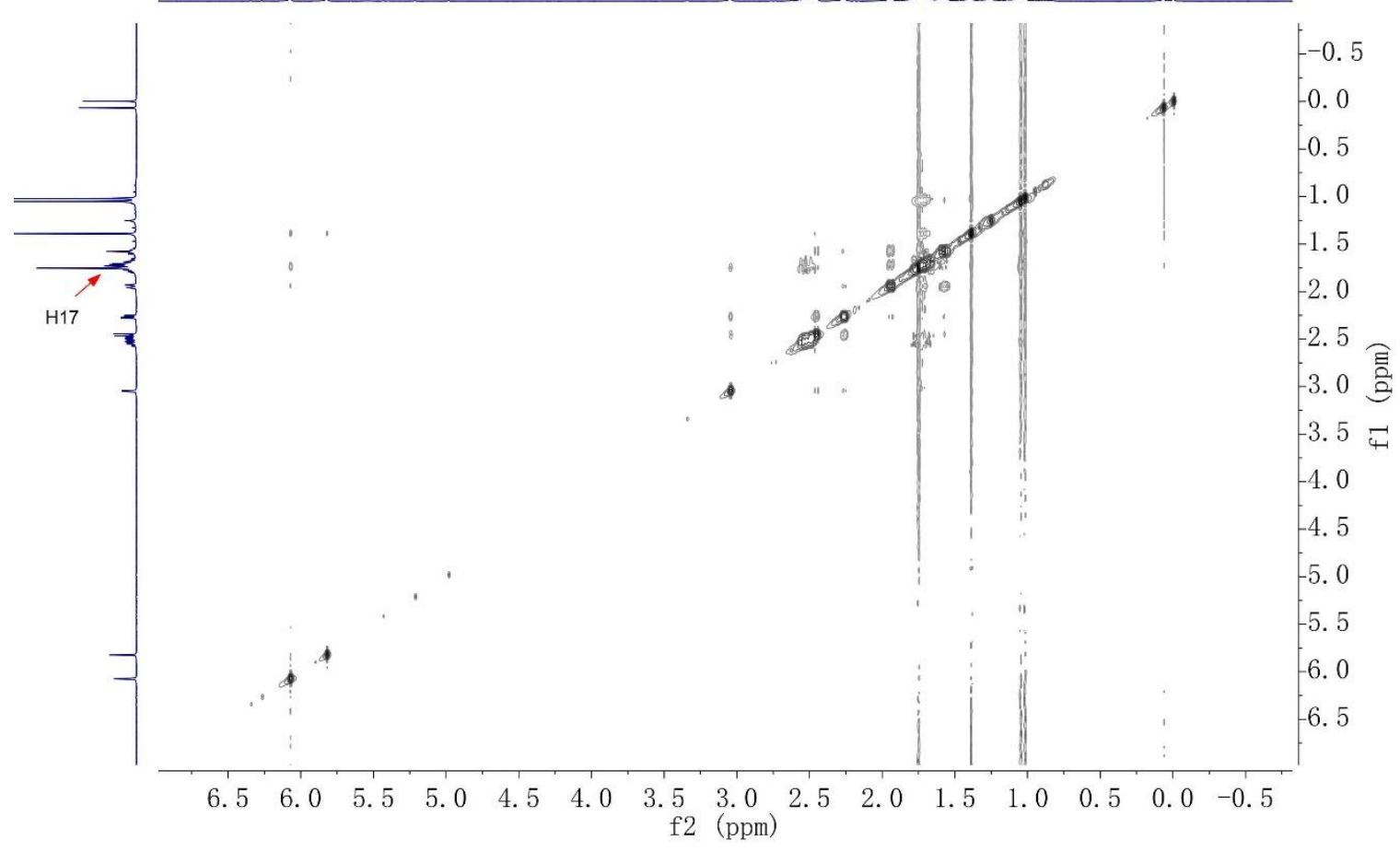




\section{HSQC spectrum of $\mathbf{1 4 d}$}
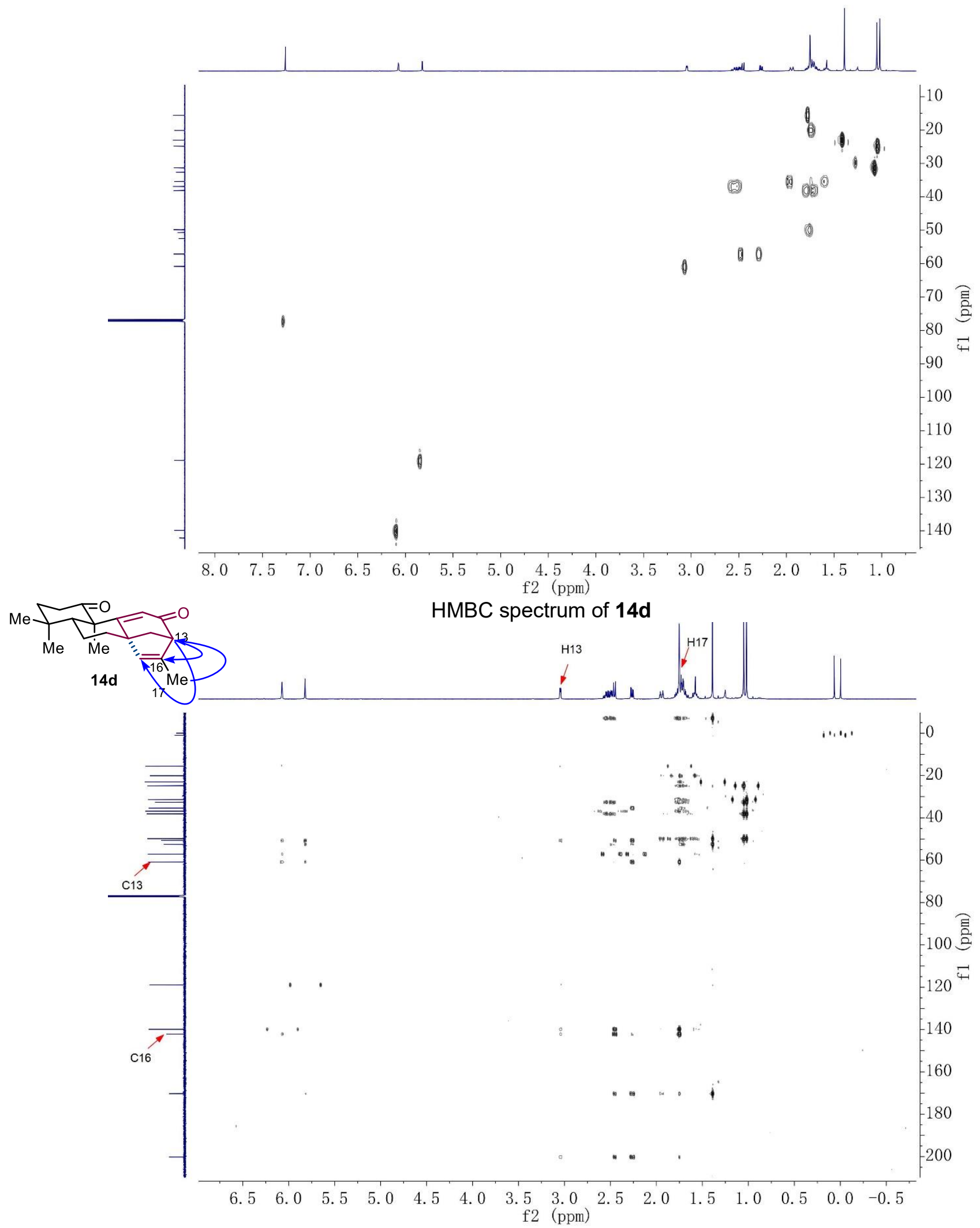


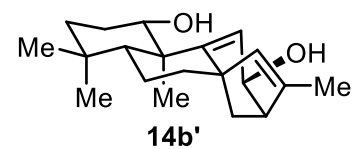

${ }^{1} \mathrm{H}-\mathrm{NMR}, \mathrm{CDCl}_{3}$

$126 \mathrm{MHz}, 298 \mathrm{~K}$
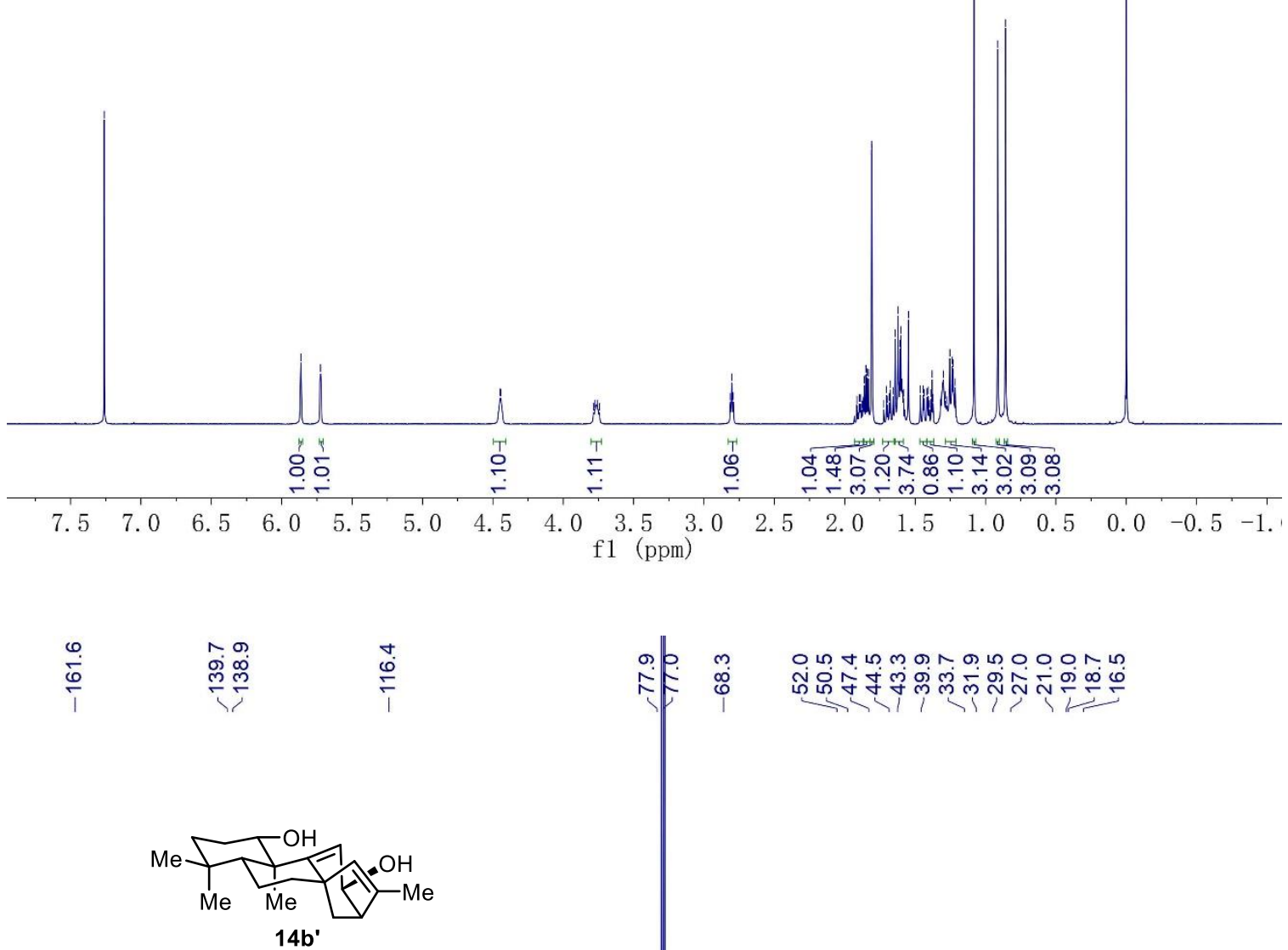

${ }^{13} \mathrm{C}-\mathrm{NMR}, \mathrm{CDCl}_{3}$

$126 \mathrm{MHz}, 298 \mathrm{~K}$

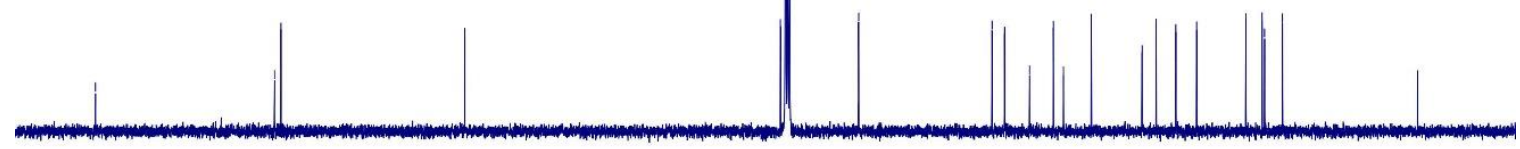

$\begin{array}{rllllllllllllllllll}70 & 160 & 150 & 140 & 130 & 120 & 110 & 100 & 90 \underset{\mathrm{f} 1}{8} \underset{(\mathrm{ppm})}{80} & 70 & 60 & 50 & 40 & 30 & 20 & 10 & 0 & -1(\end{array}$ 

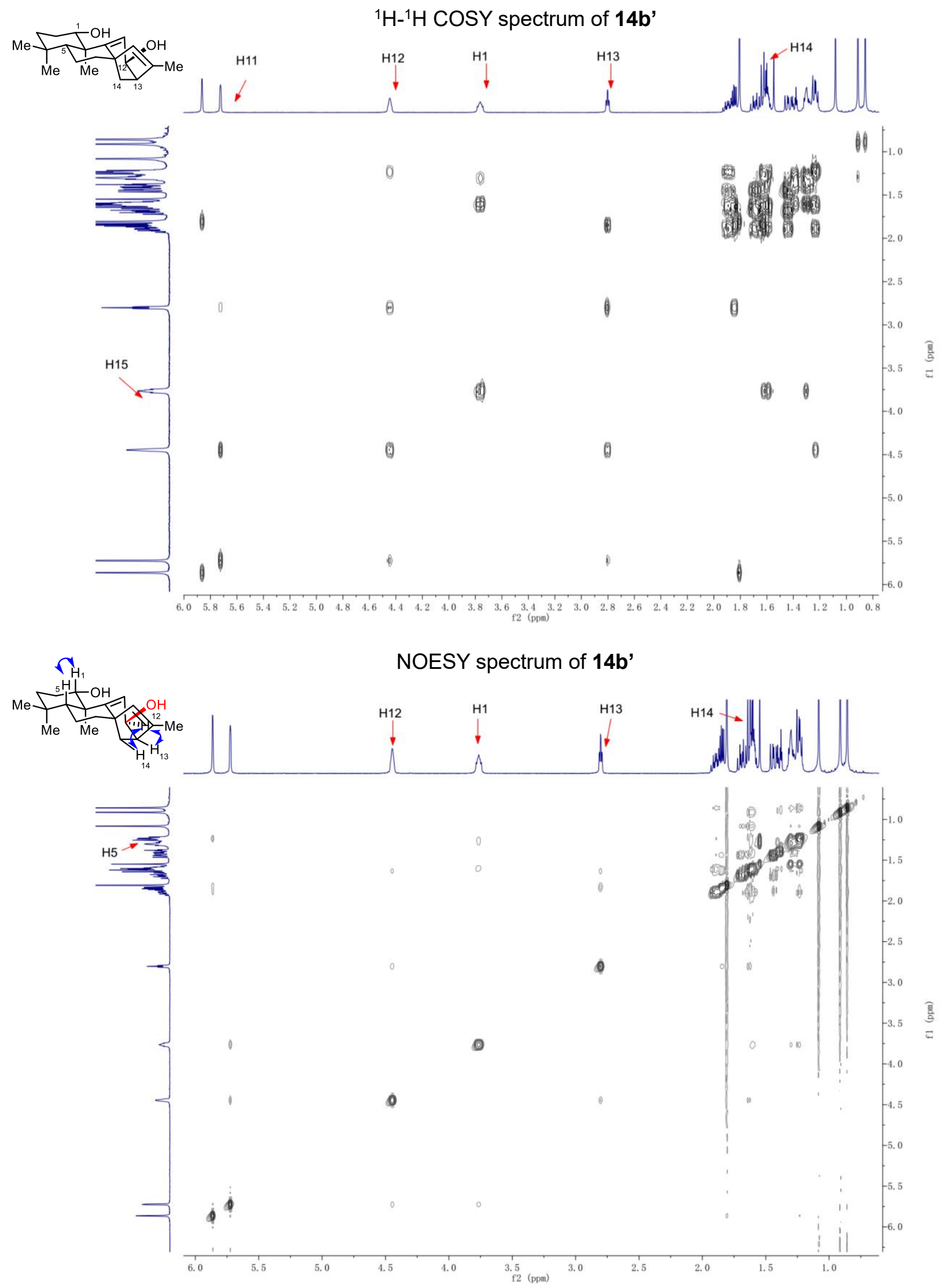
HSQC spectrum of 14b'

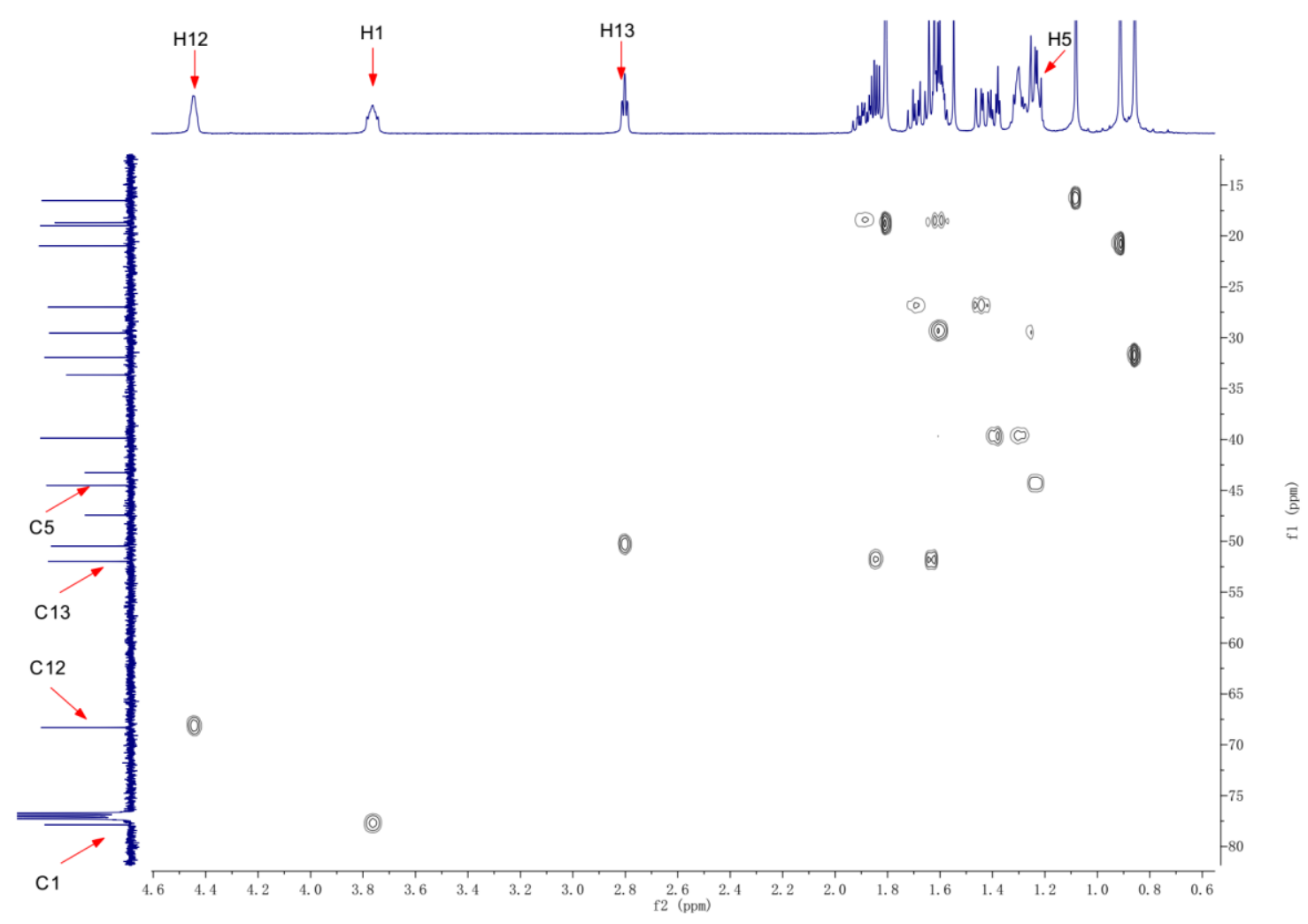

HMBC spectrum of 14b'

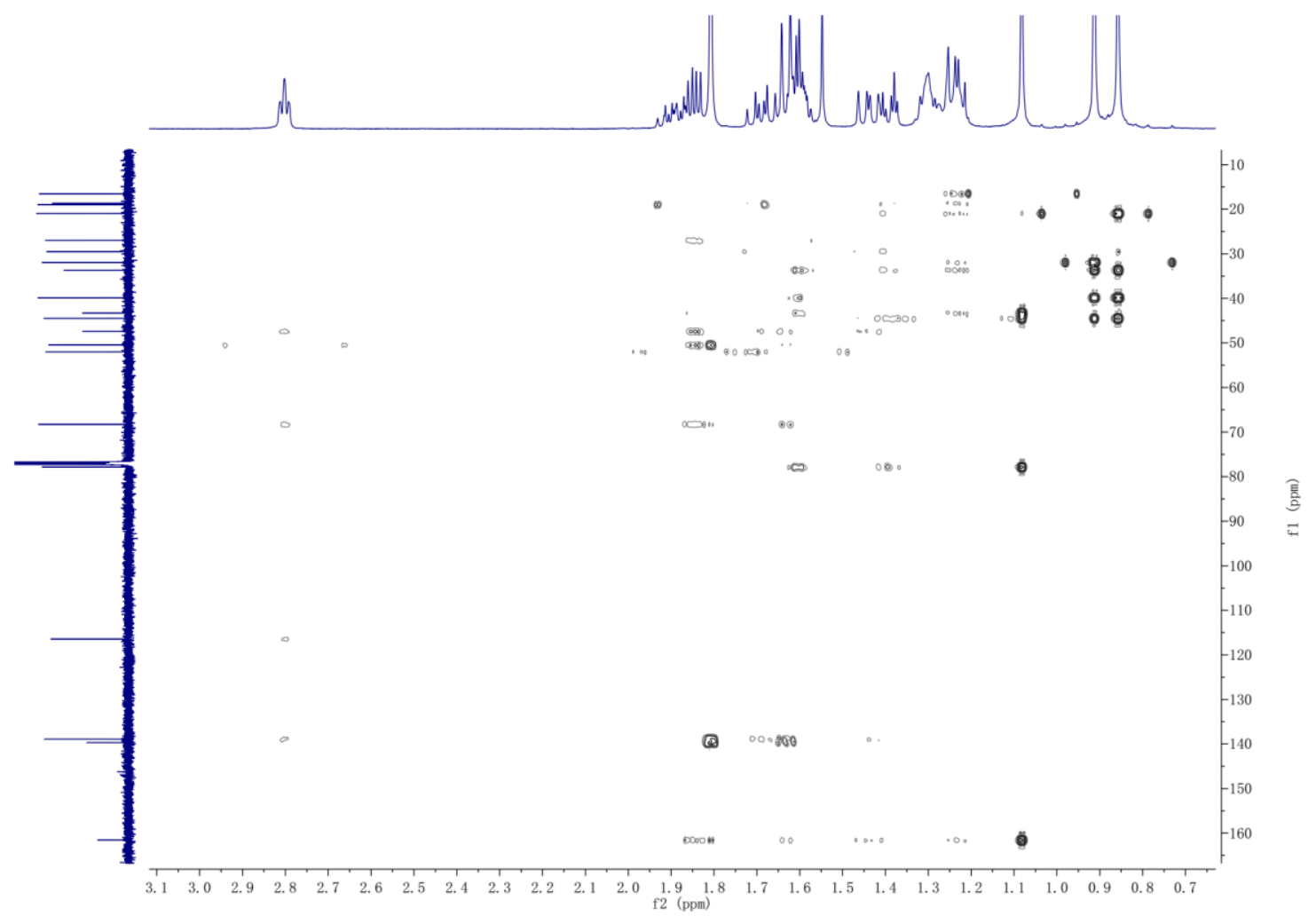



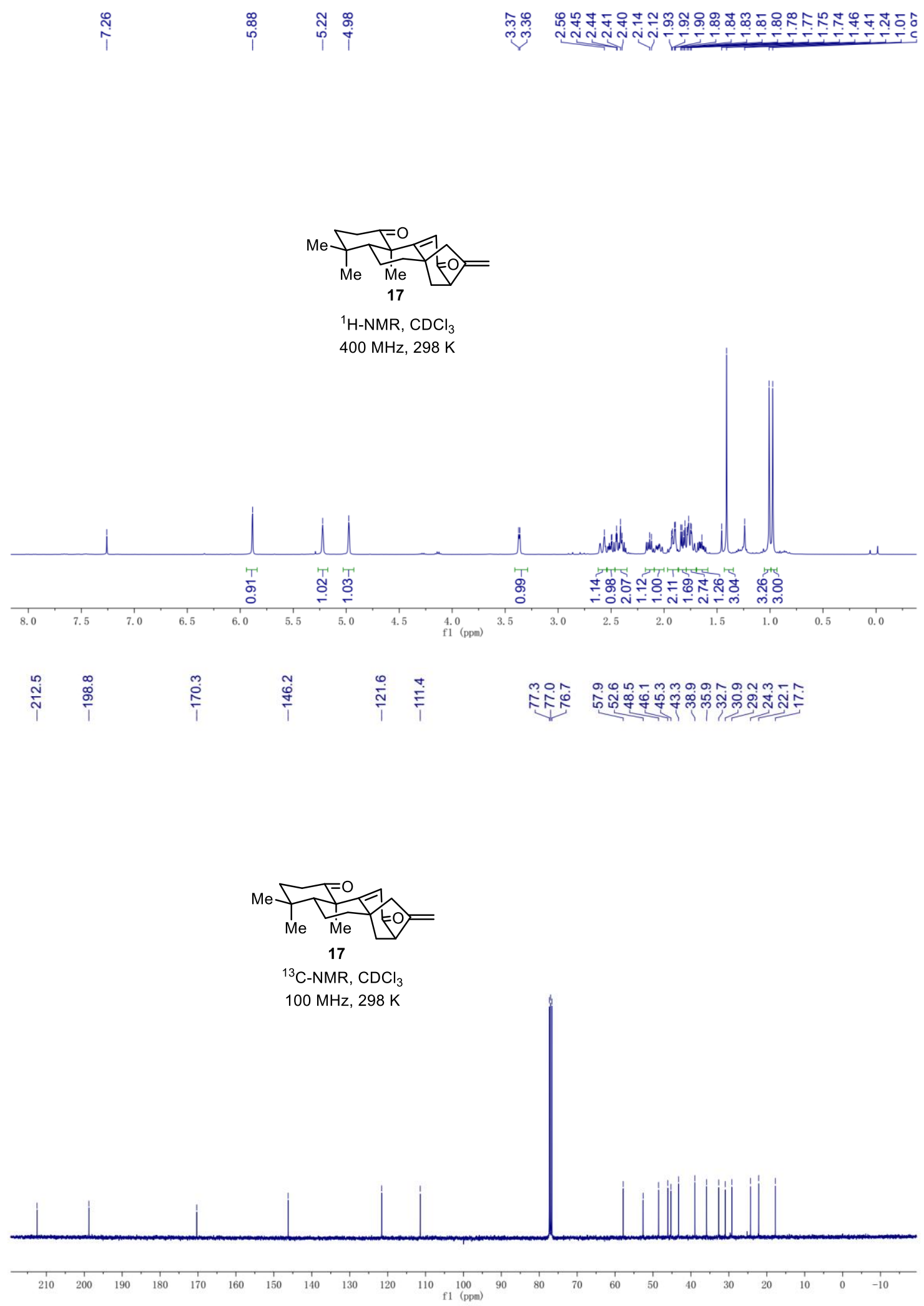

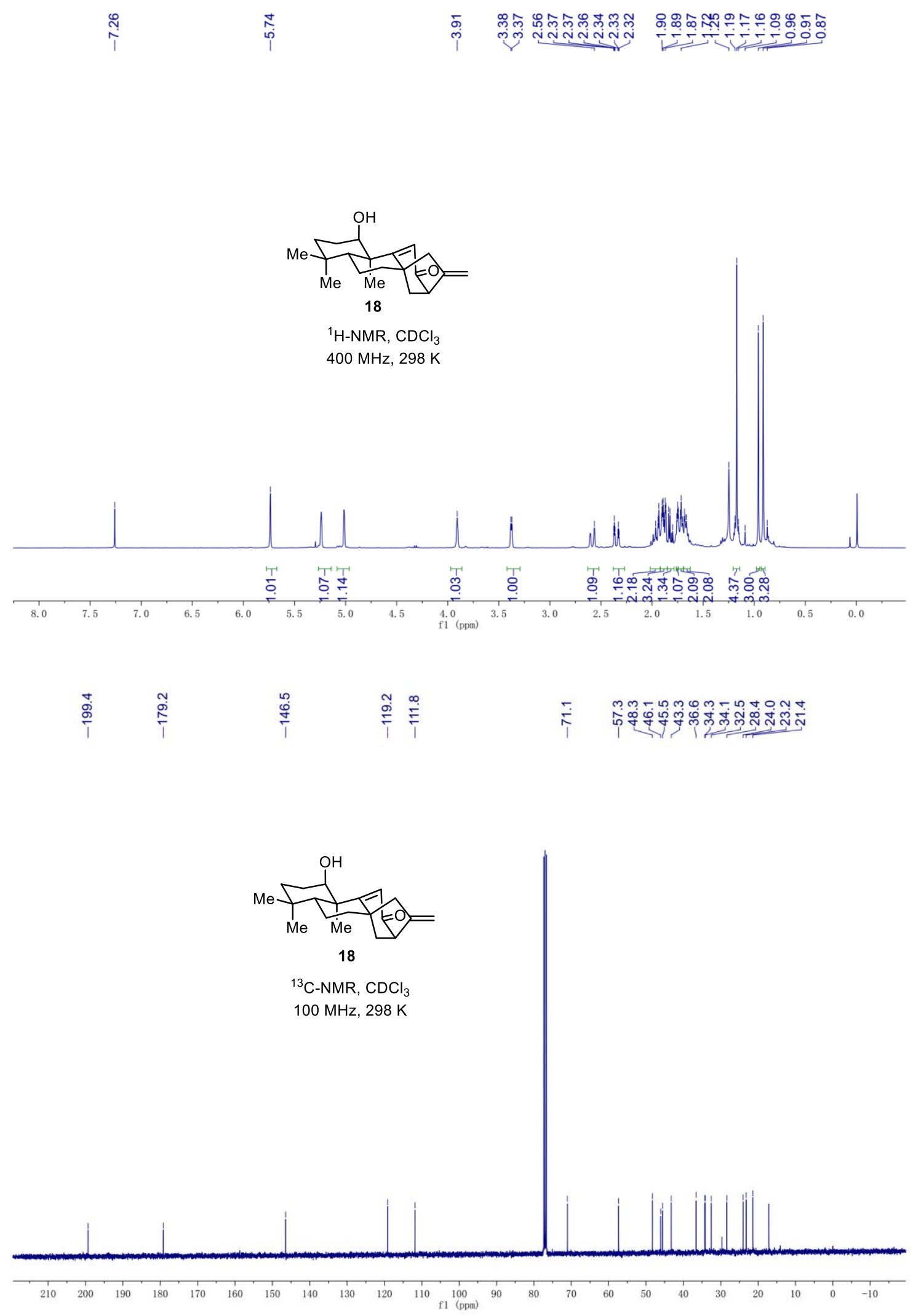
${ }^{1} \mathrm{H}-{ }^{1} \mathrm{H}$ COSY spectrum of 18
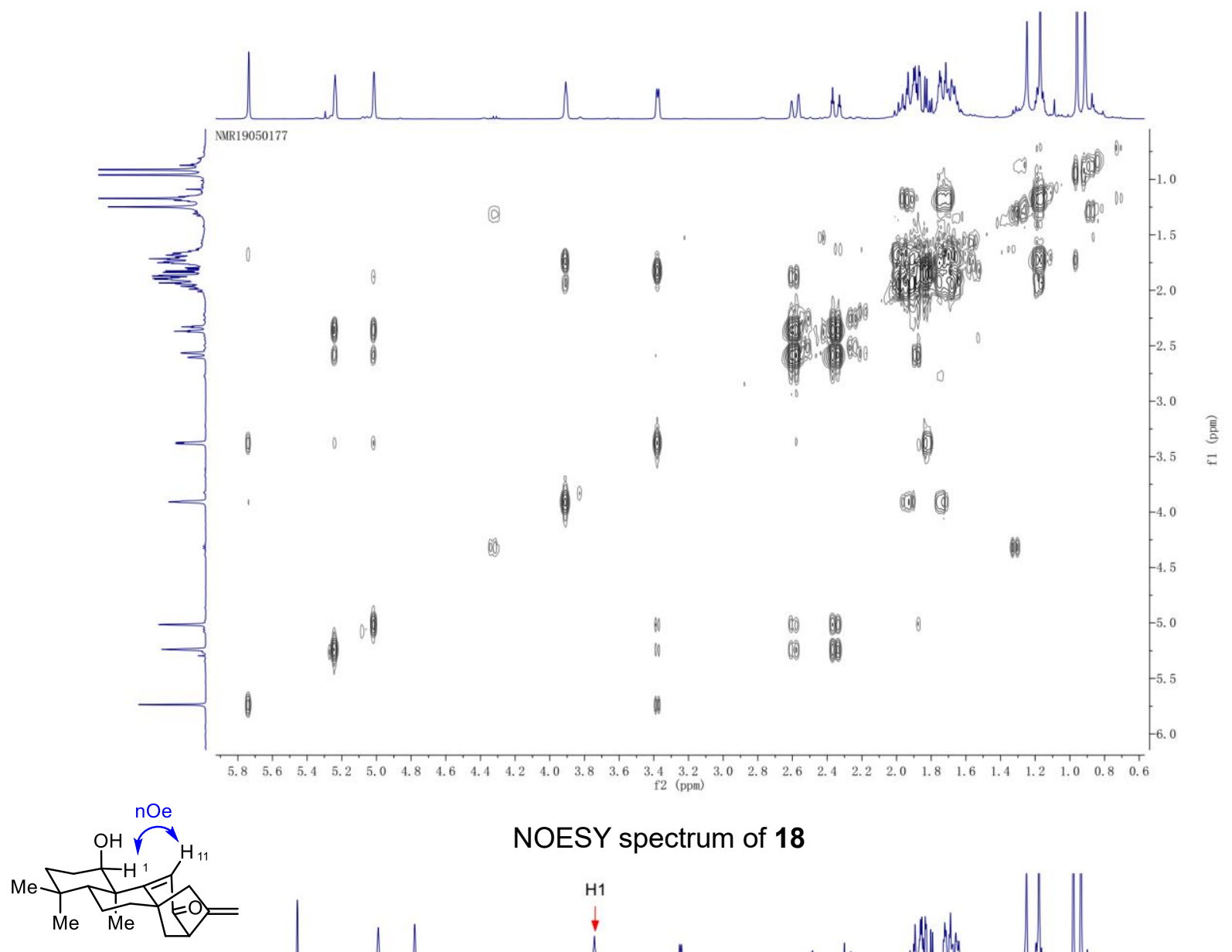

NOESY spectrum of 18

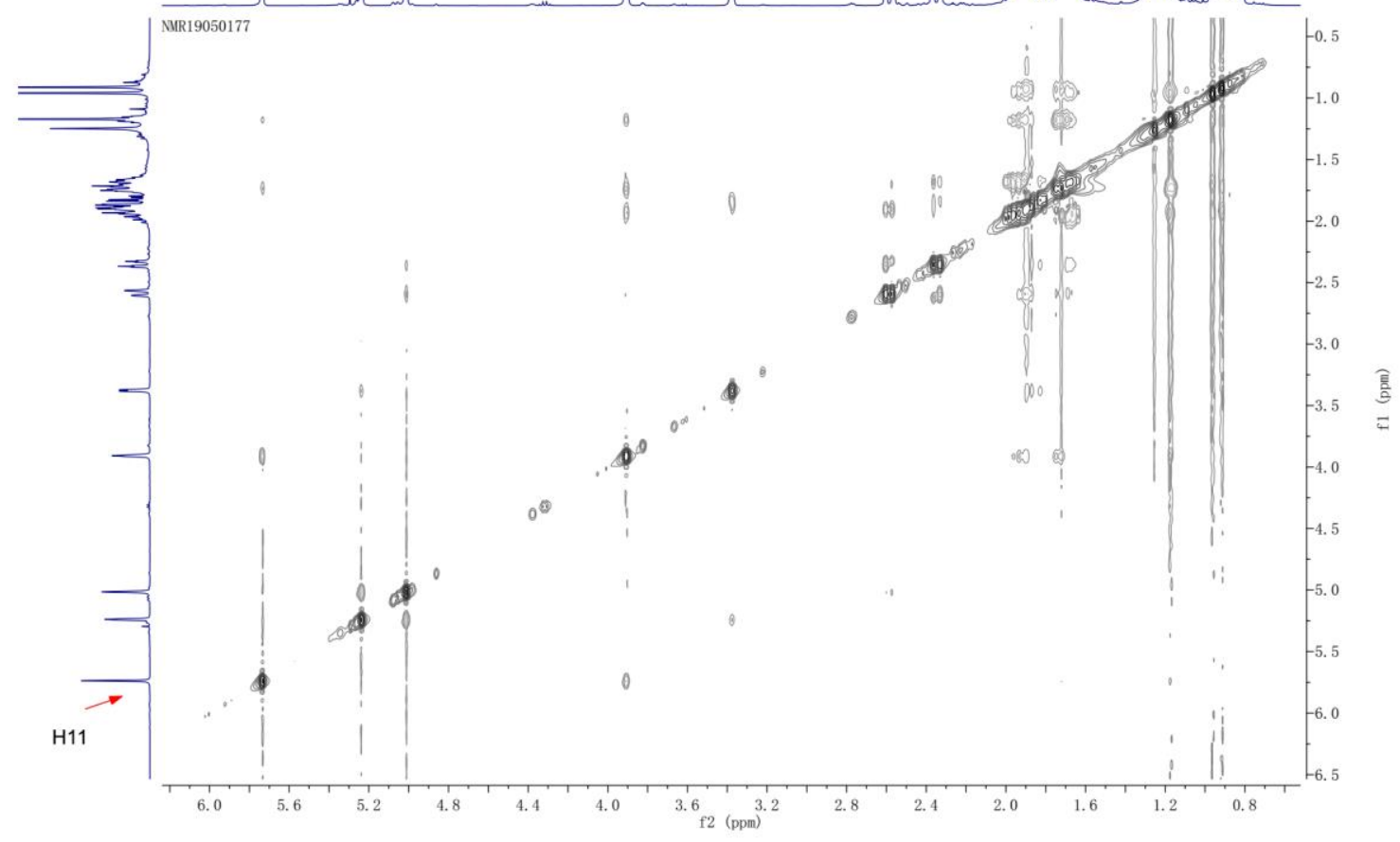




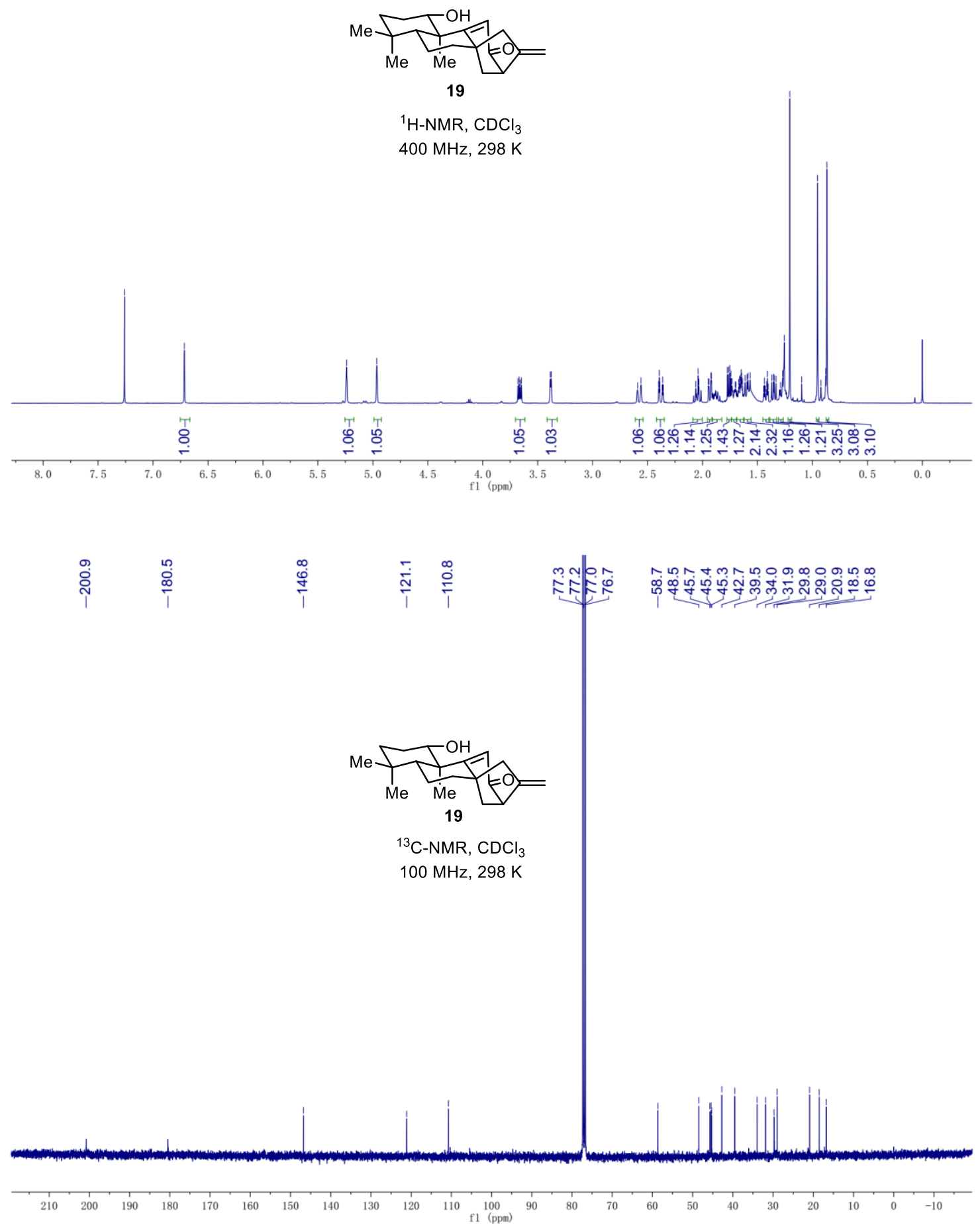


HSQC spectrum of 19

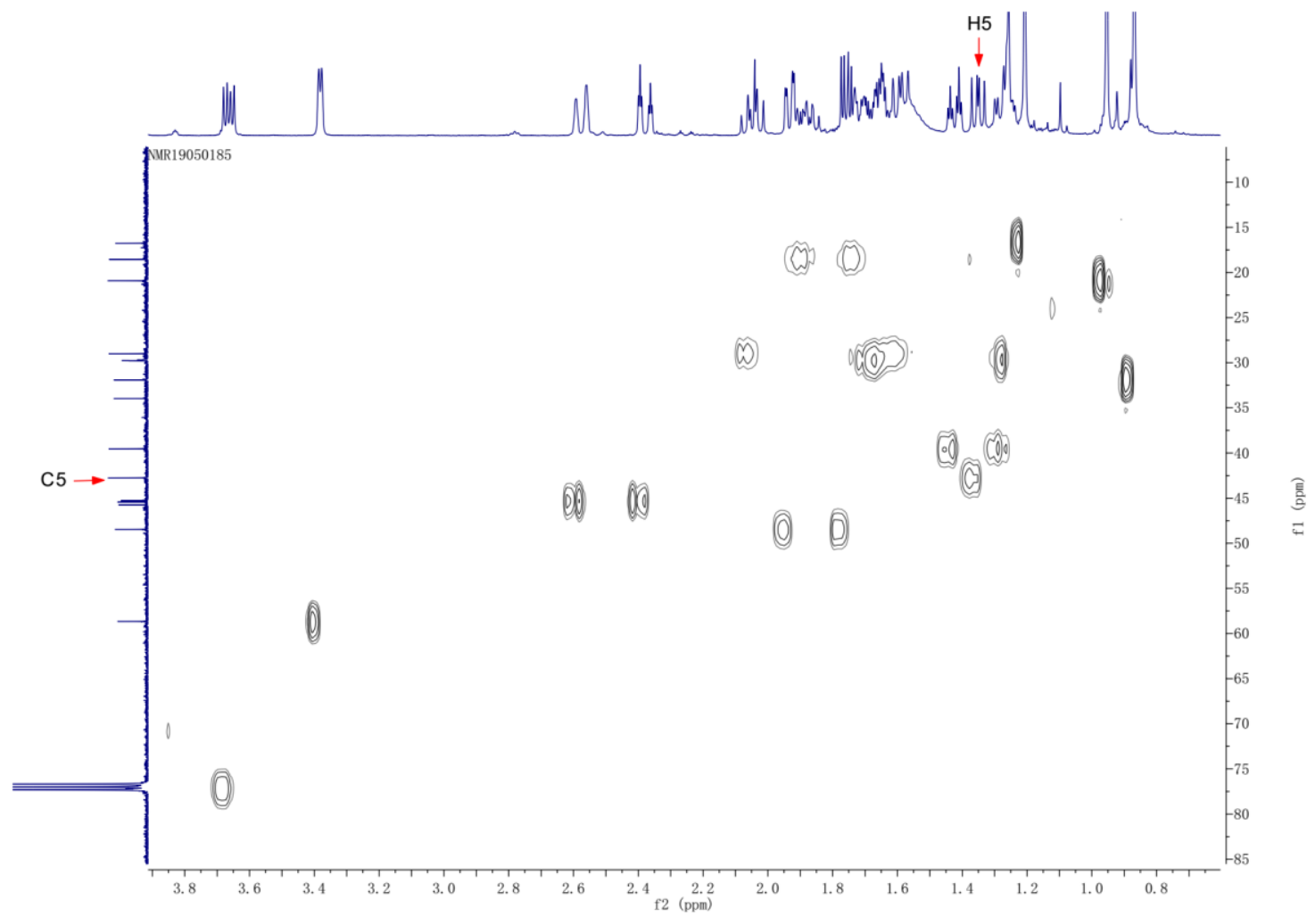

NOESY spectrum of 19

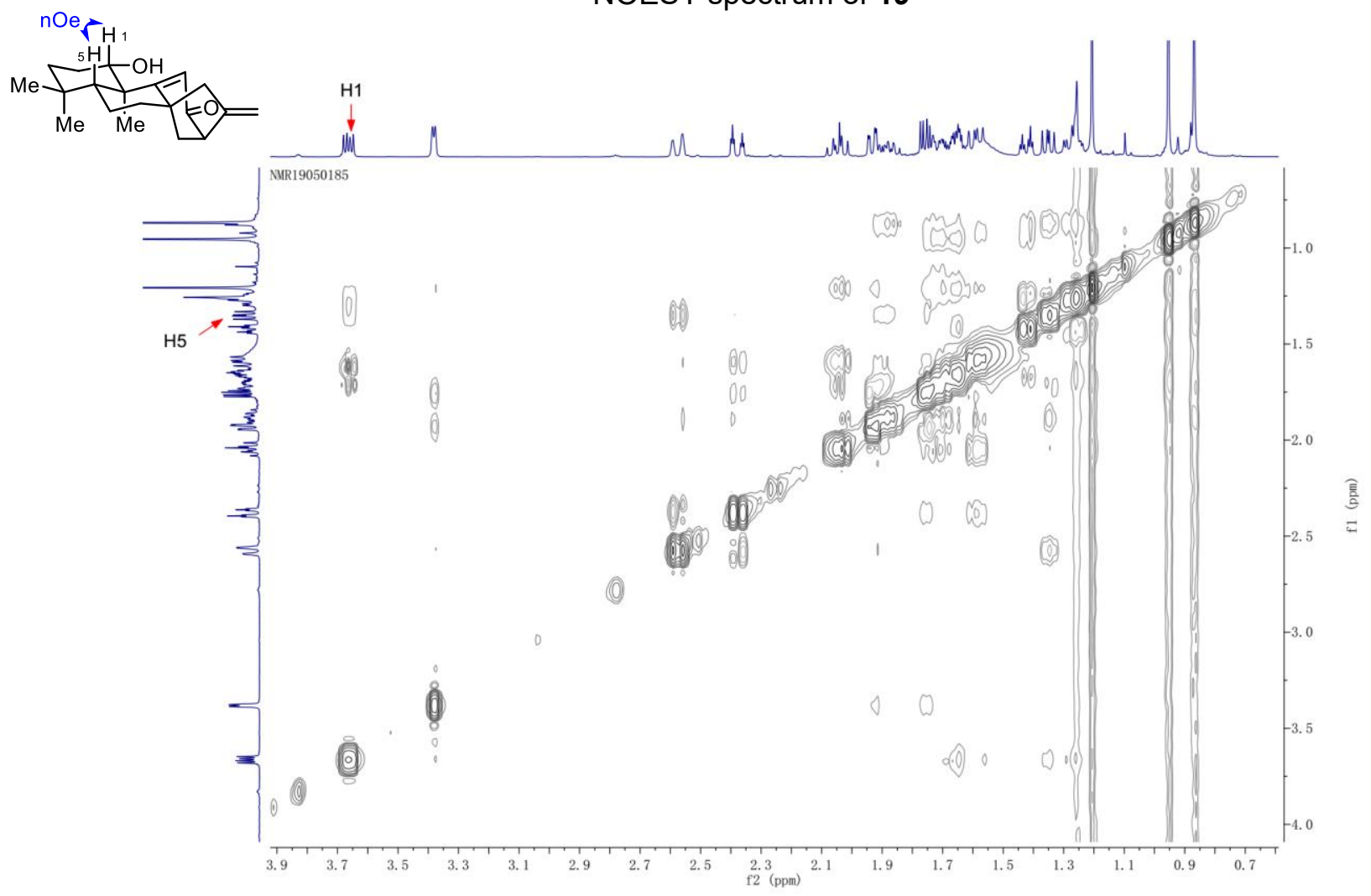




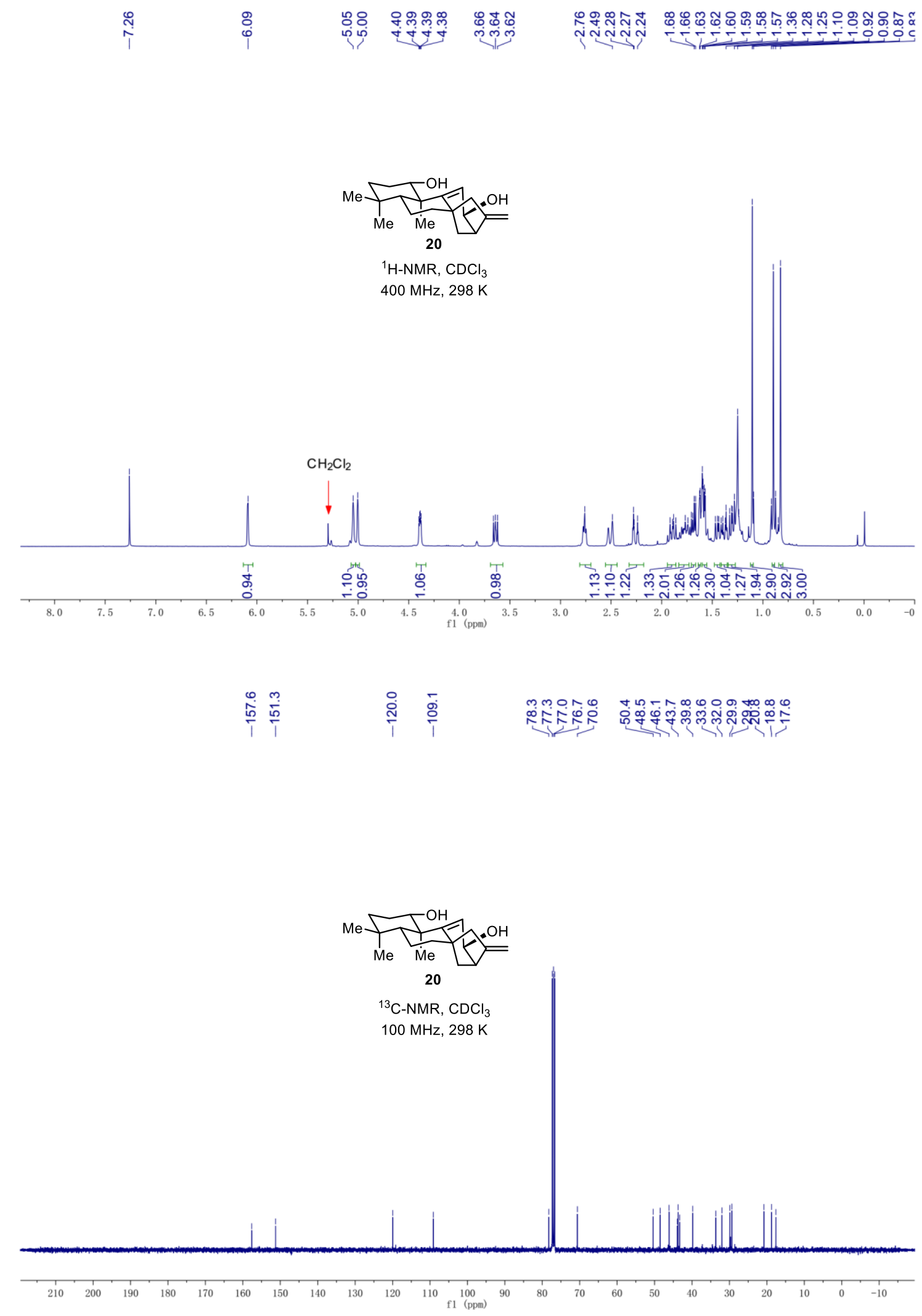


${ }^{1} \mathrm{H}-{ }^{1} \mathrm{H}$ COSY spectrum of 20

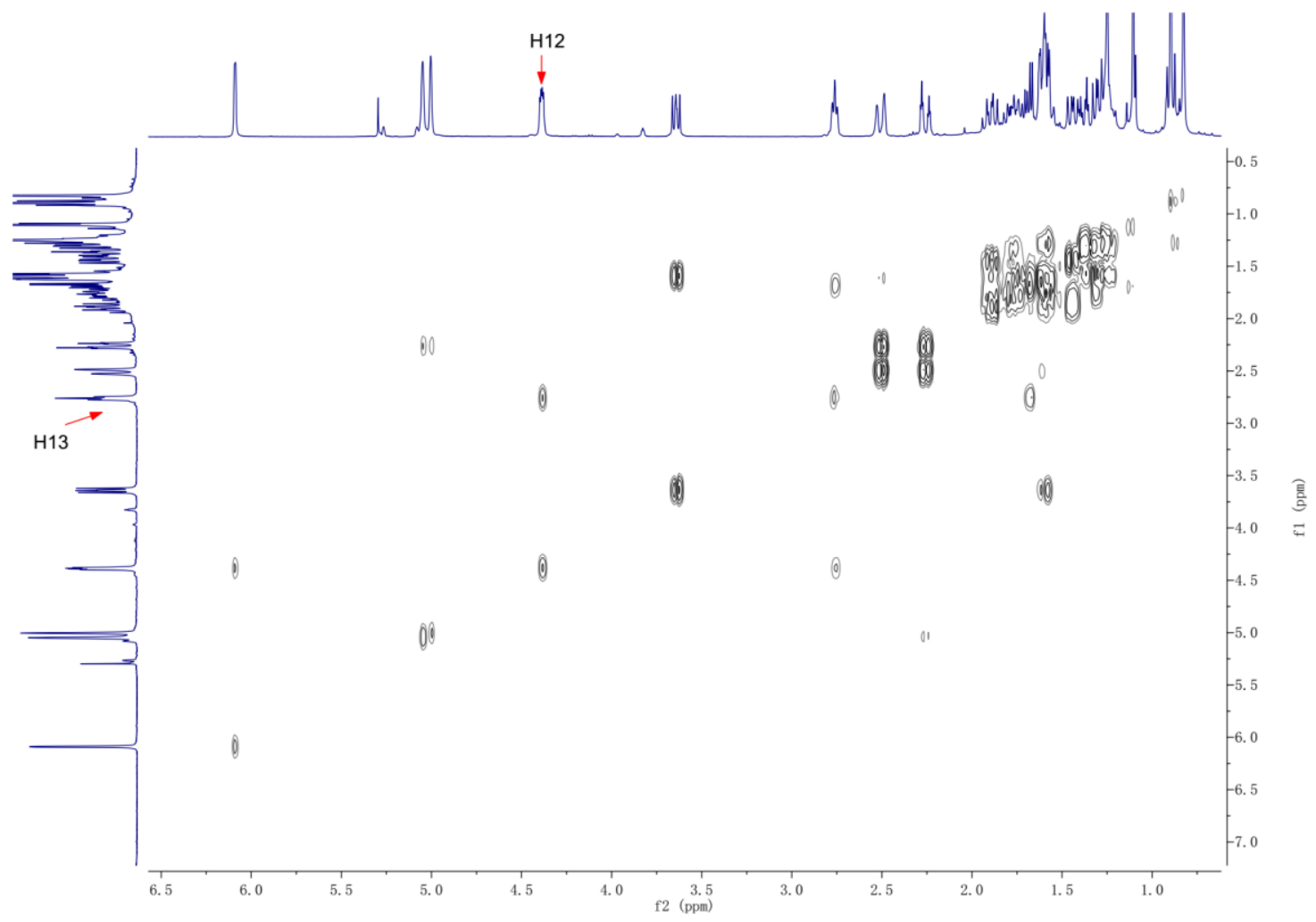

NOESY spectrum of $\mathbf{2 0}$

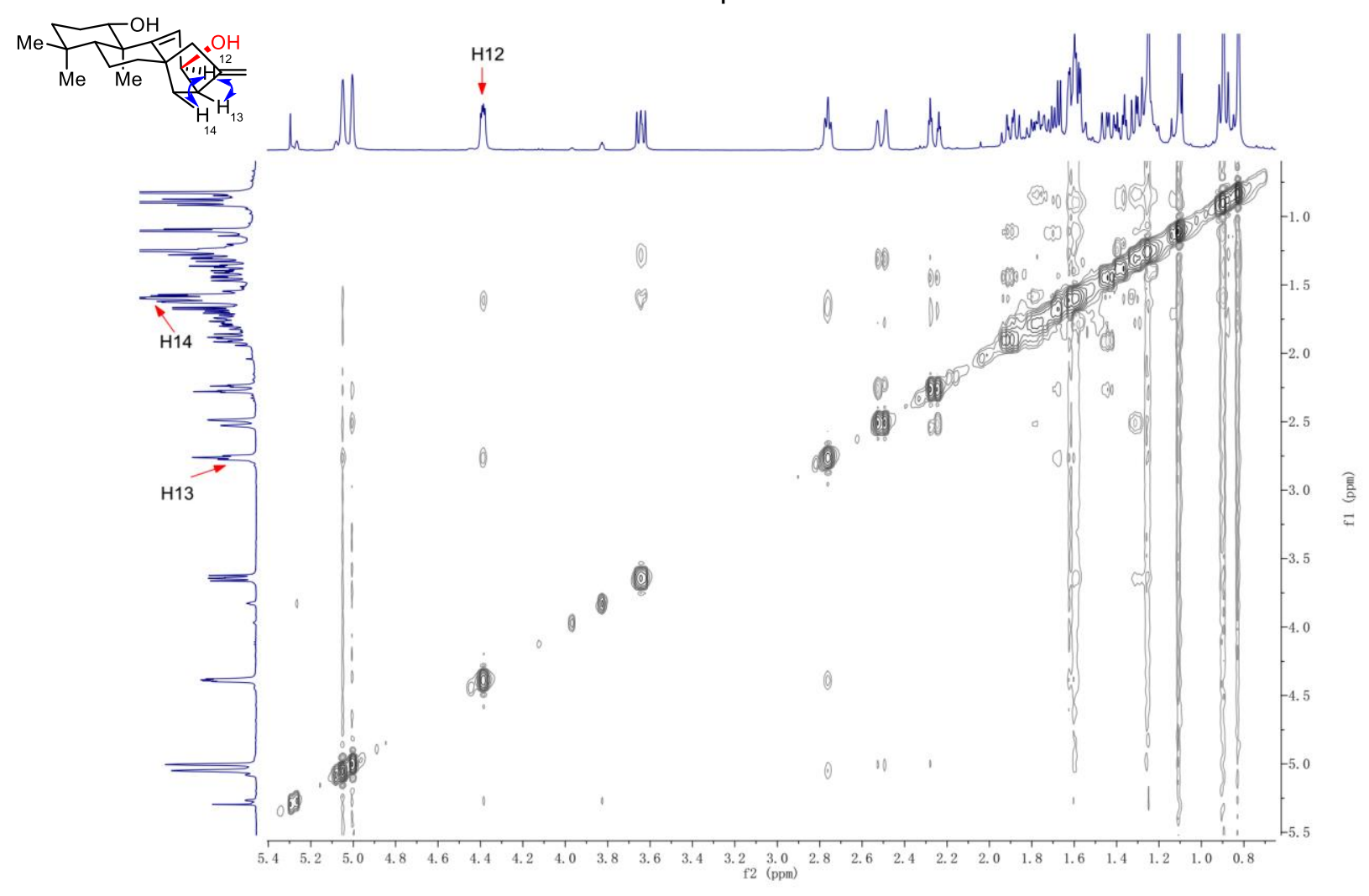




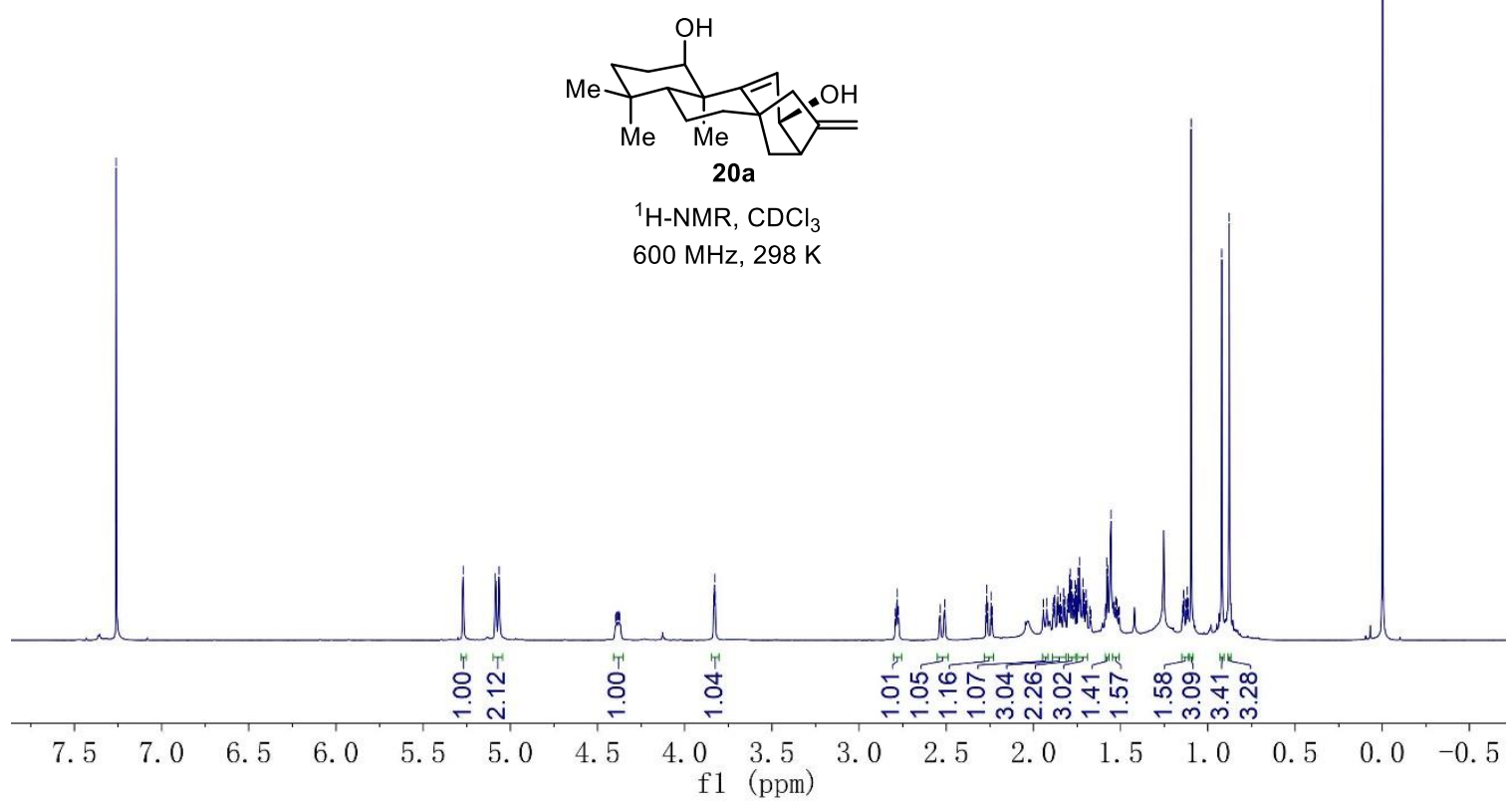

${ }^{13} \mathrm{C}-\mathrm{NMR}, \mathrm{CDCl}_{3}$ $150 \mathrm{MHz}, 298 \mathrm{~K}$
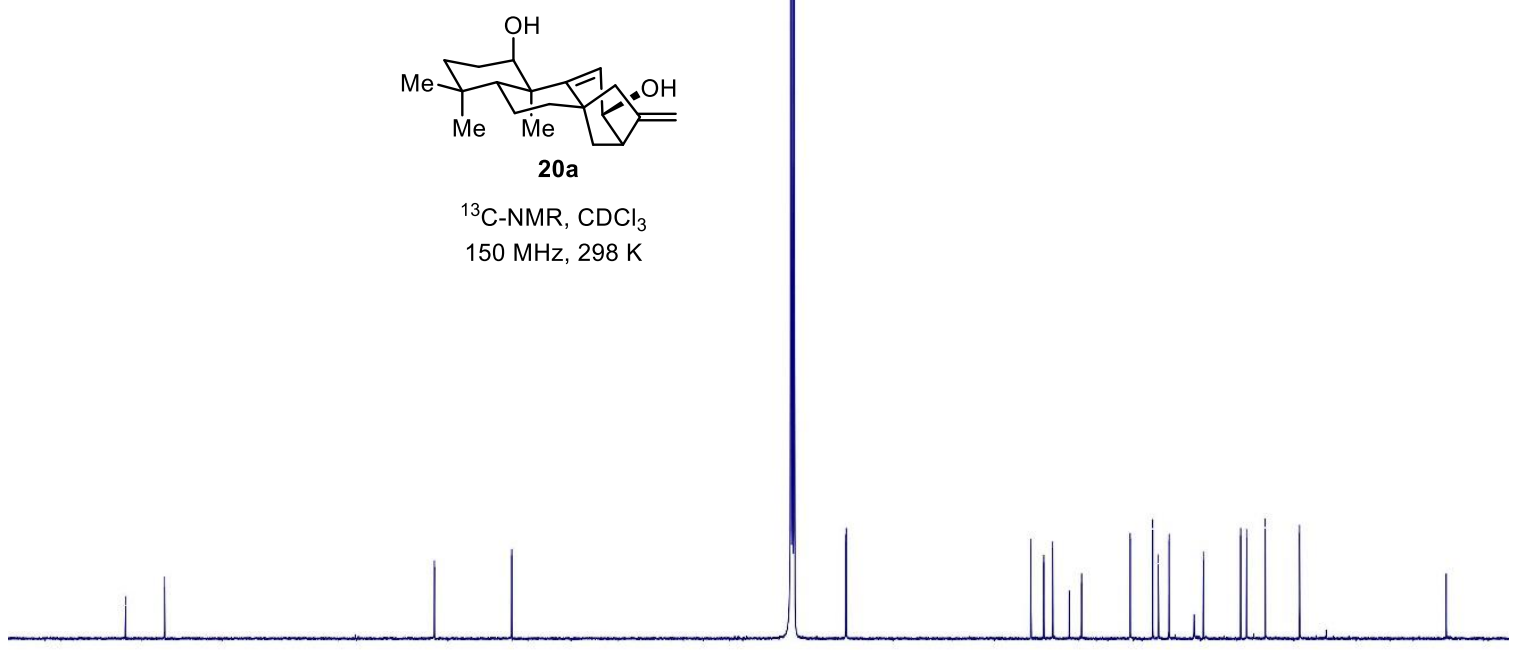

$\begin{array}{llll}160 & 150 & 140 & 130\end{array}$

120

90

f1 $(\mathrm{ppm})$ 
${ }^{1} \mathrm{H}-{ }^{1} \mathrm{H}$ COSY spectrum of $\mathbf{2 0 a}$
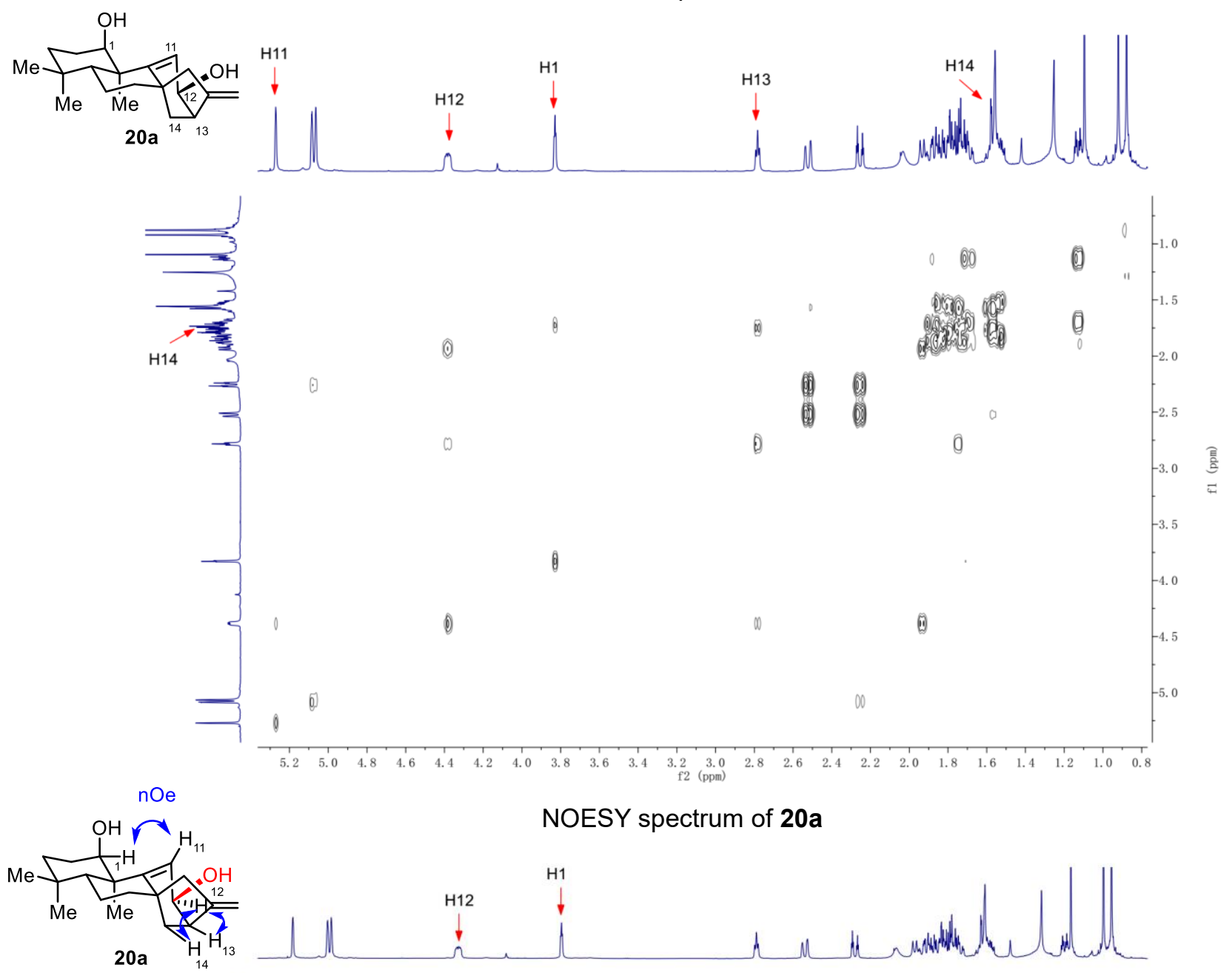

\section{NOESY spectrum of $20 a$}

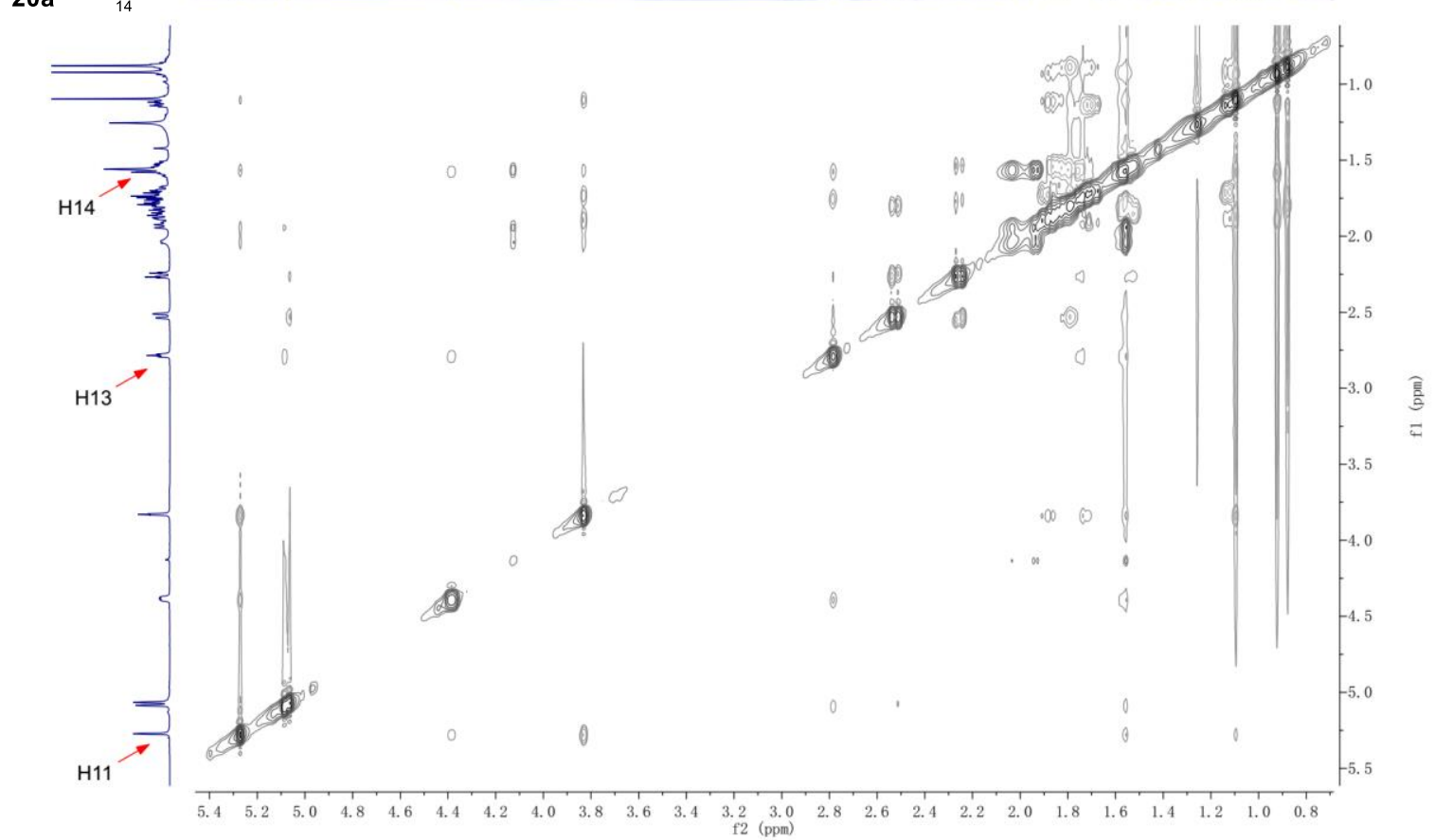



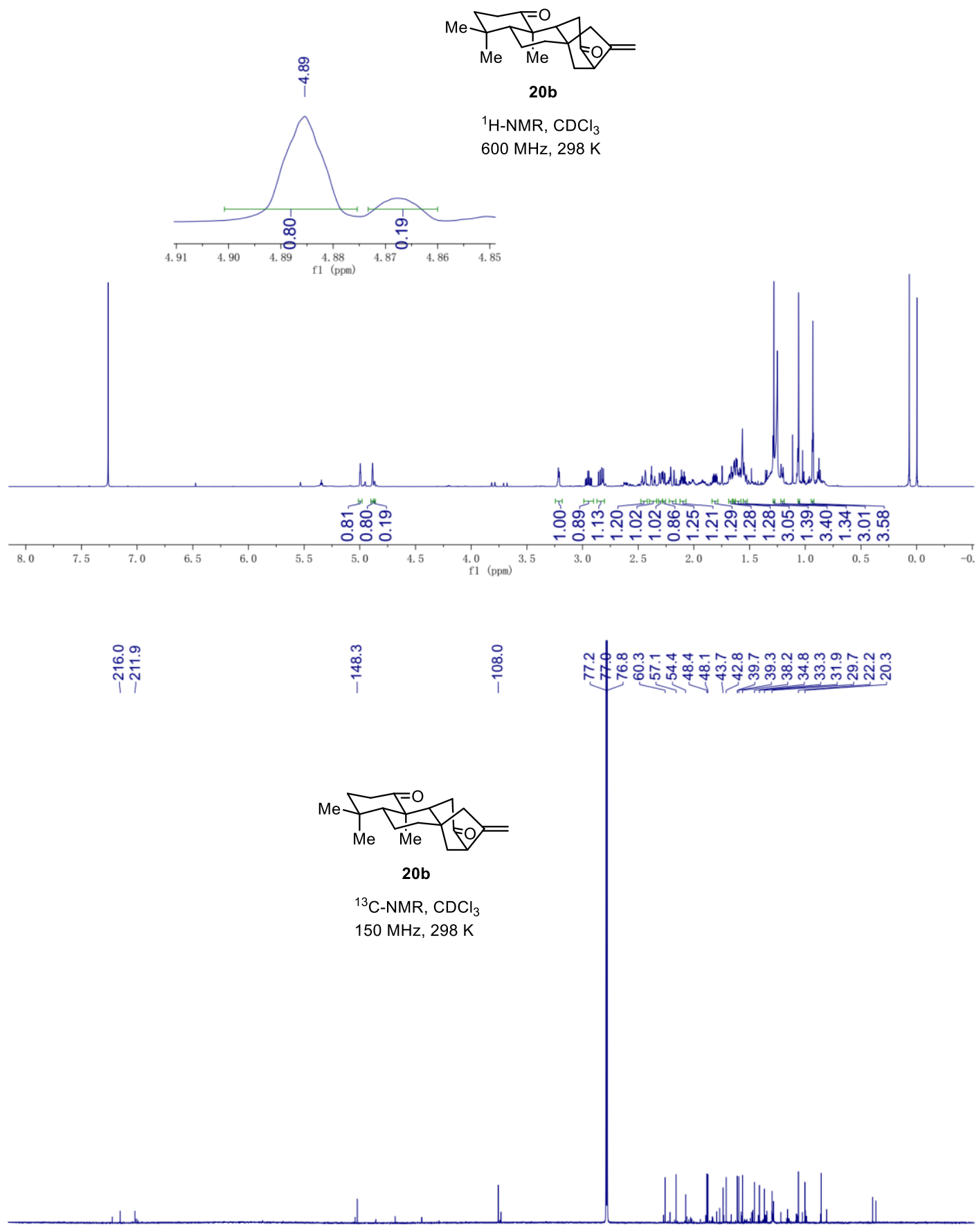

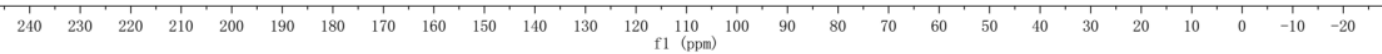




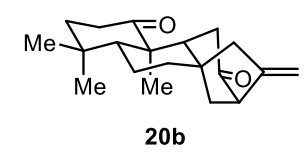

DEPT, $\mathrm{CDCl}_{3}$ $150 \mathrm{MHz}, 298 \mathrm{~K}$

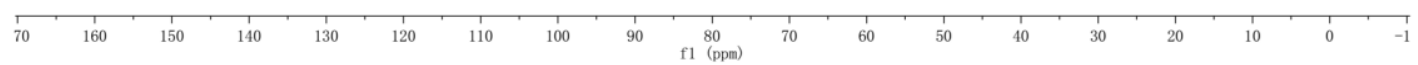

HSQC spectrum of $\mathbf{2 0 b}$

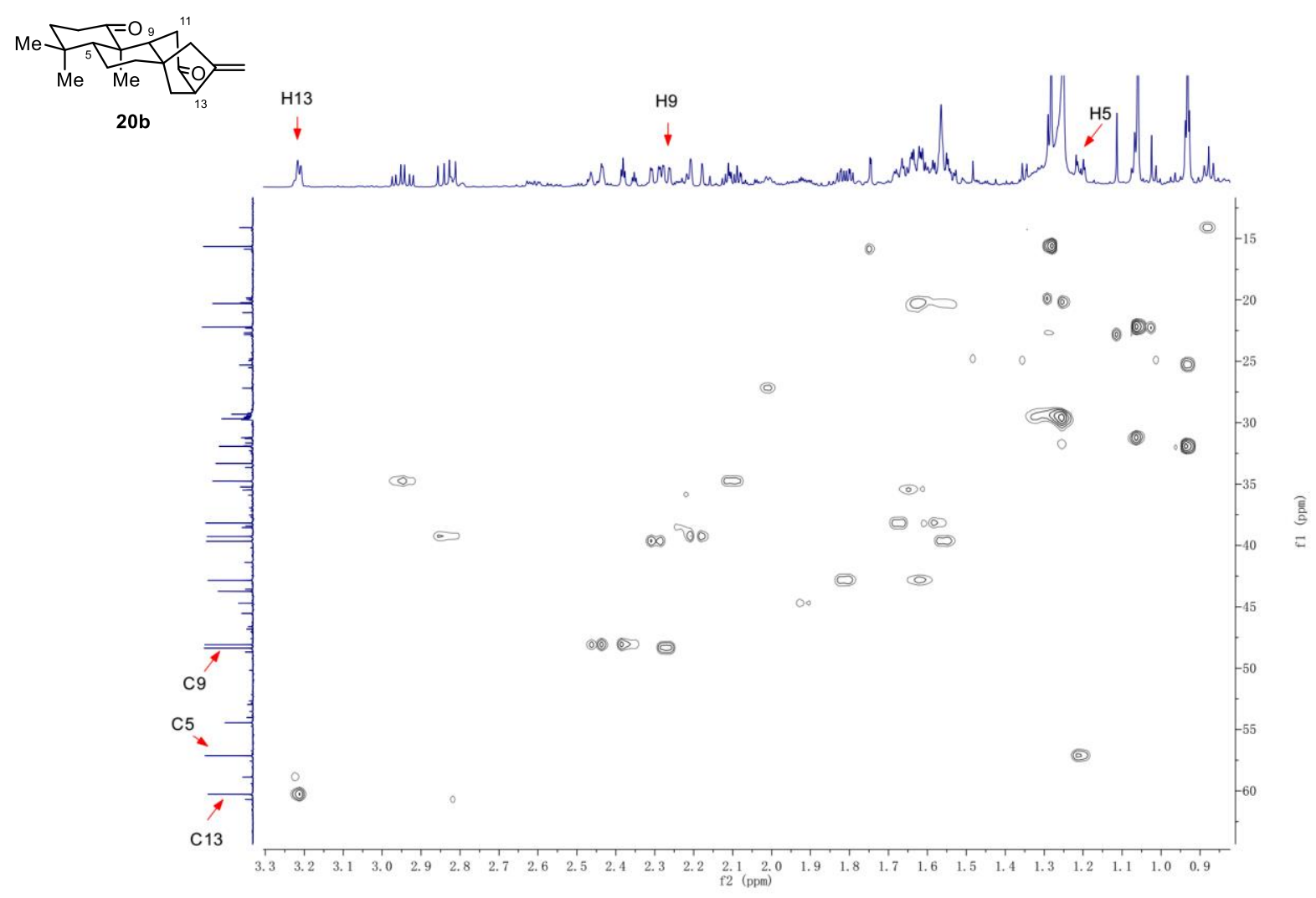




\section{${ }^{1} \mathrm{H}-{ }^{1} \mathrm{H}$ COSY spectrum of $20 \mathrm{~b}$}
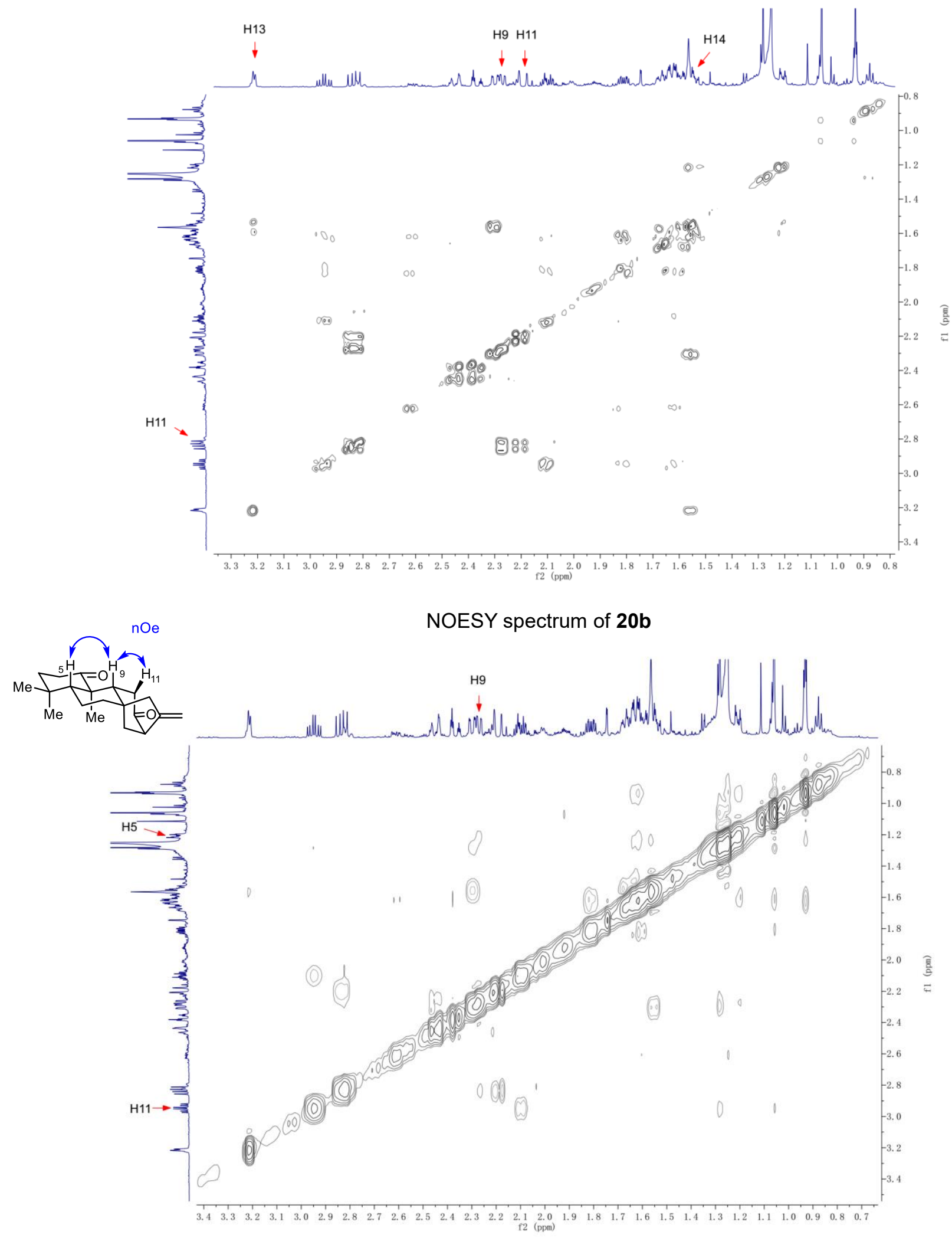


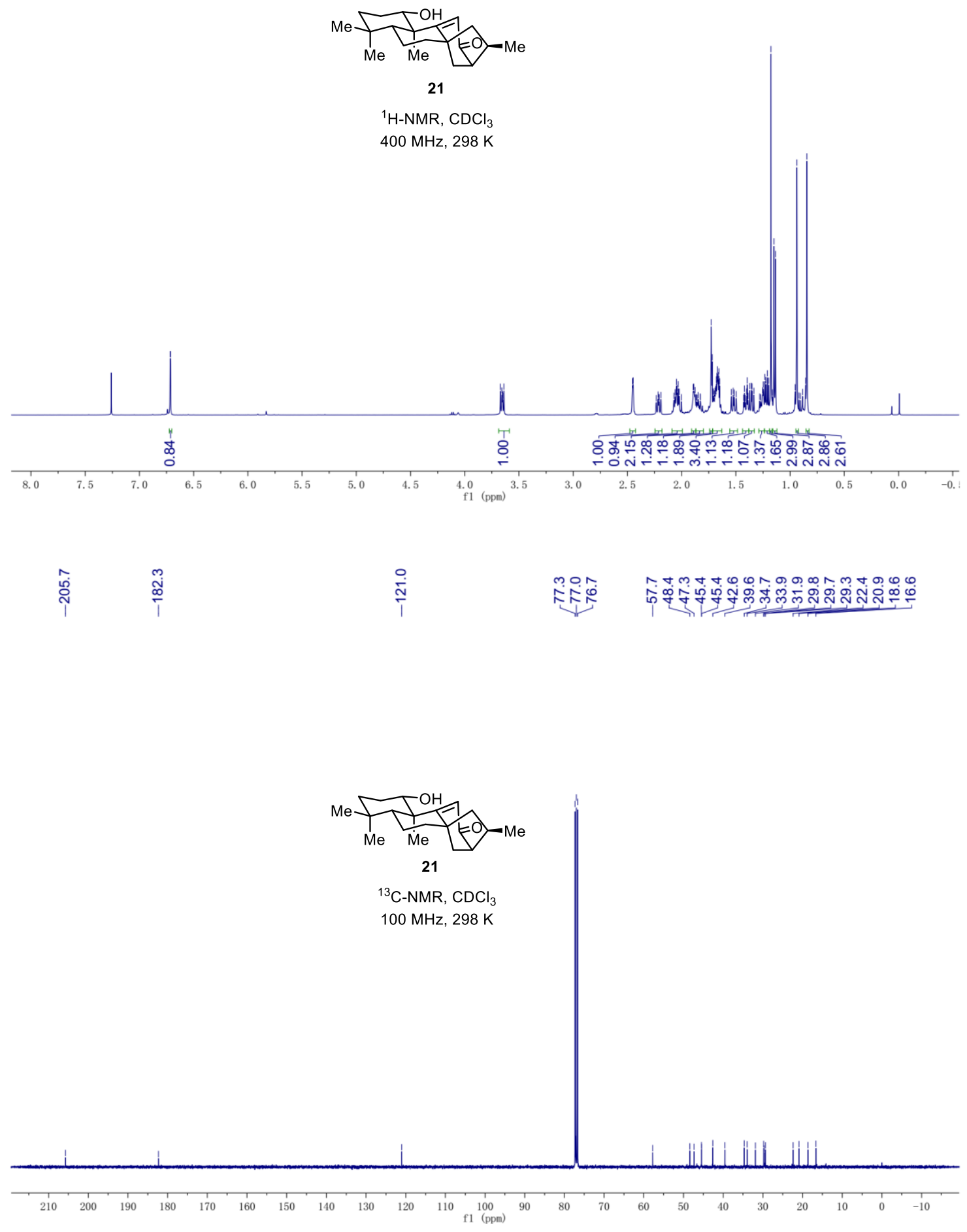


${ }^{1} \mathrm{H}-{ }^{1} \mathrm{H}$ COSY spectrum of $\mathbf{2 1}$

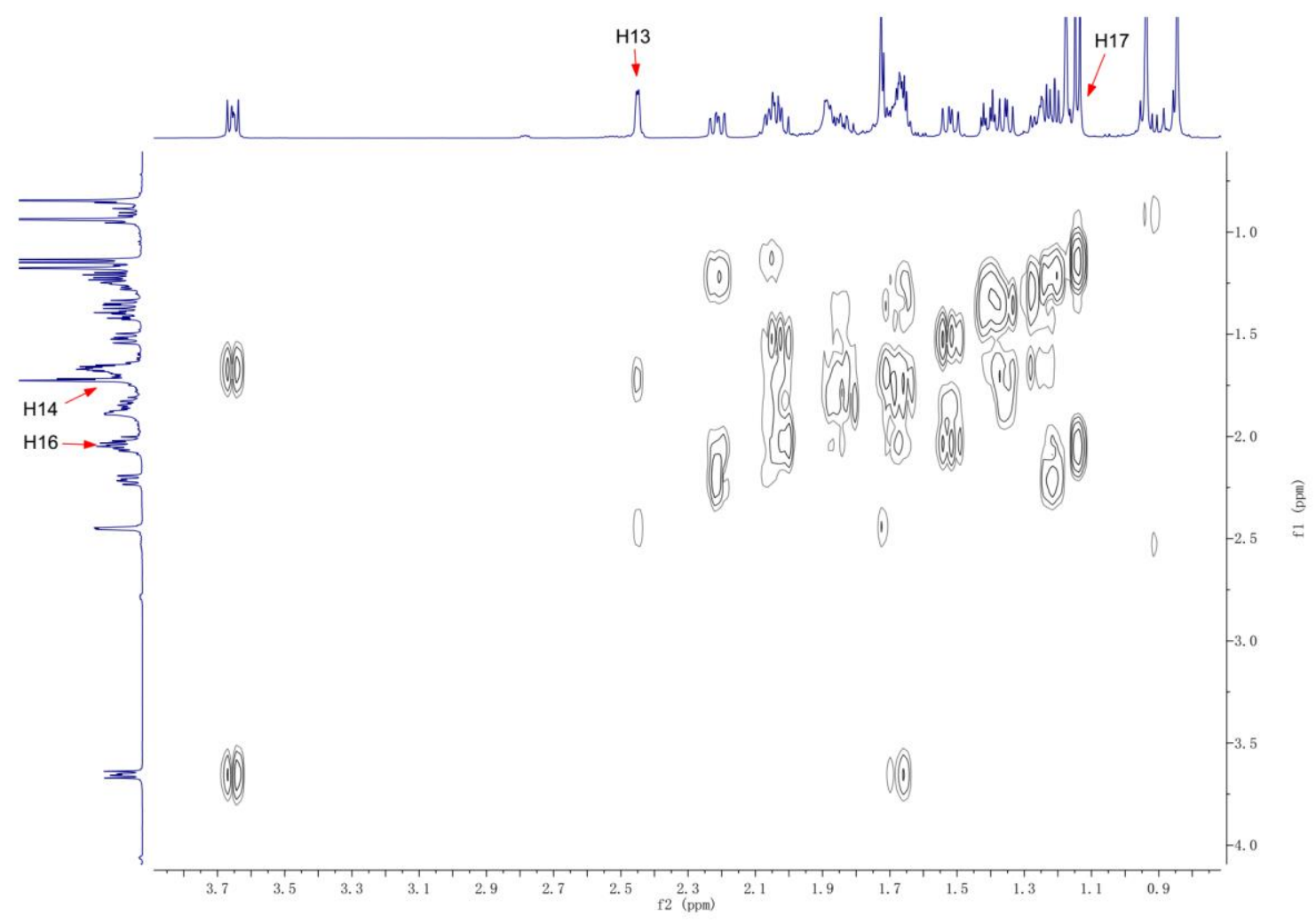

NOESY spectrum of $\mathbf{2 1}$

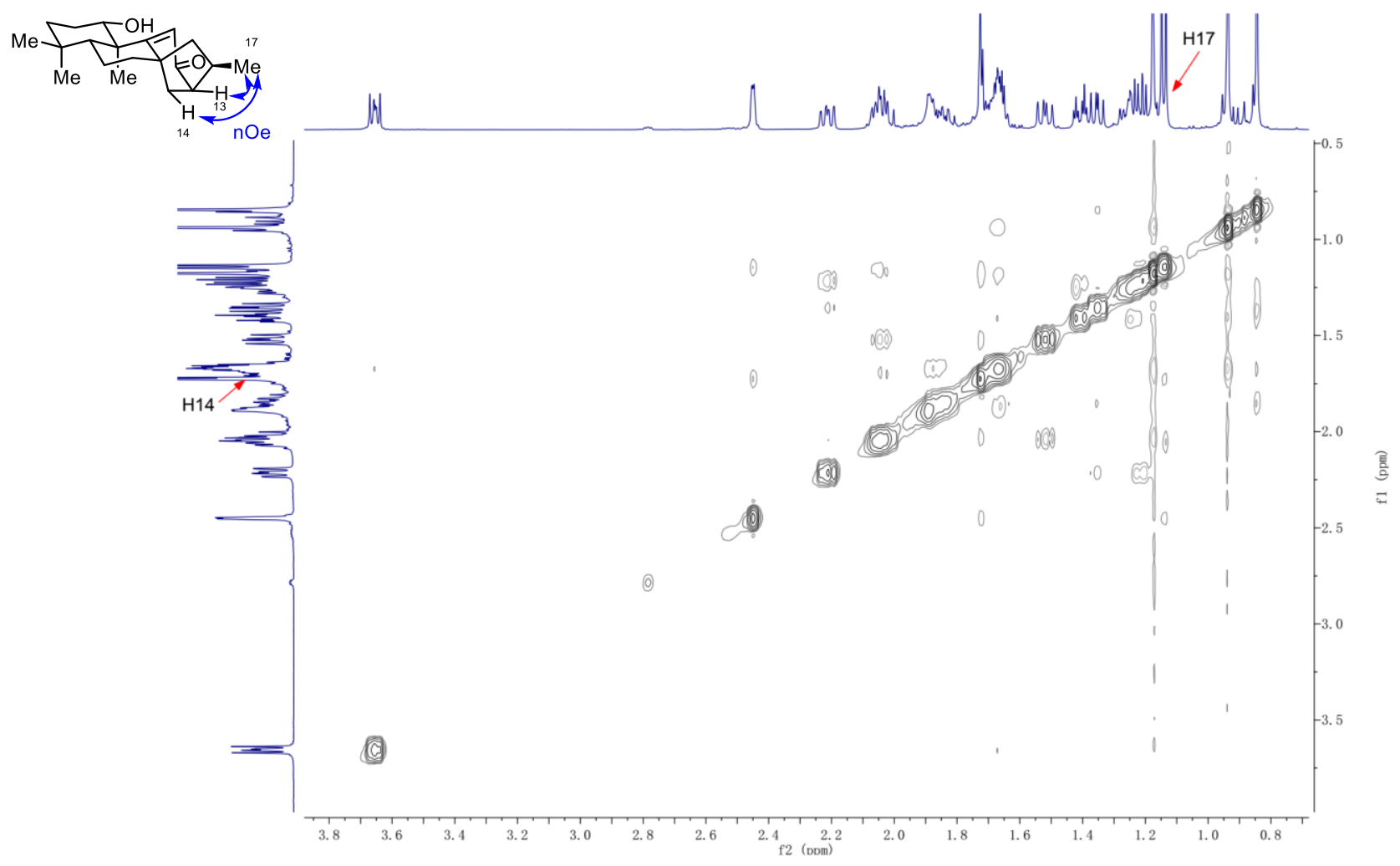



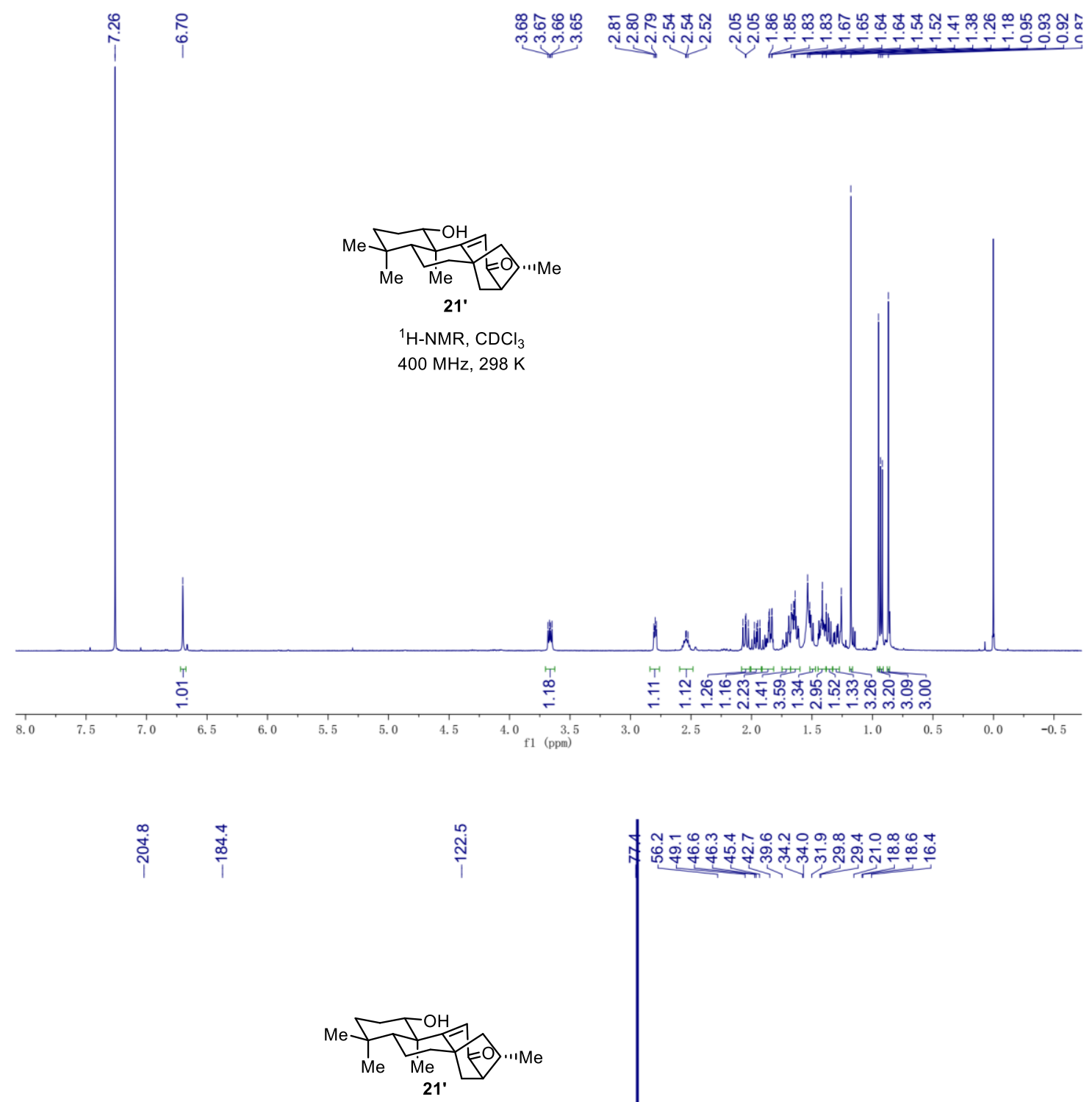

${ }^{13} \mathrm{C}-\mathrm{NMR}, \mathrm{CDCl}_{3}$ $100 \mathrm{MHz}, 298 \mathrm{~K}$ 


\section{${ }^{1} \mathrm{H}-{ }^{1} \mathrm{H}$ COSY spectrum of 21'}

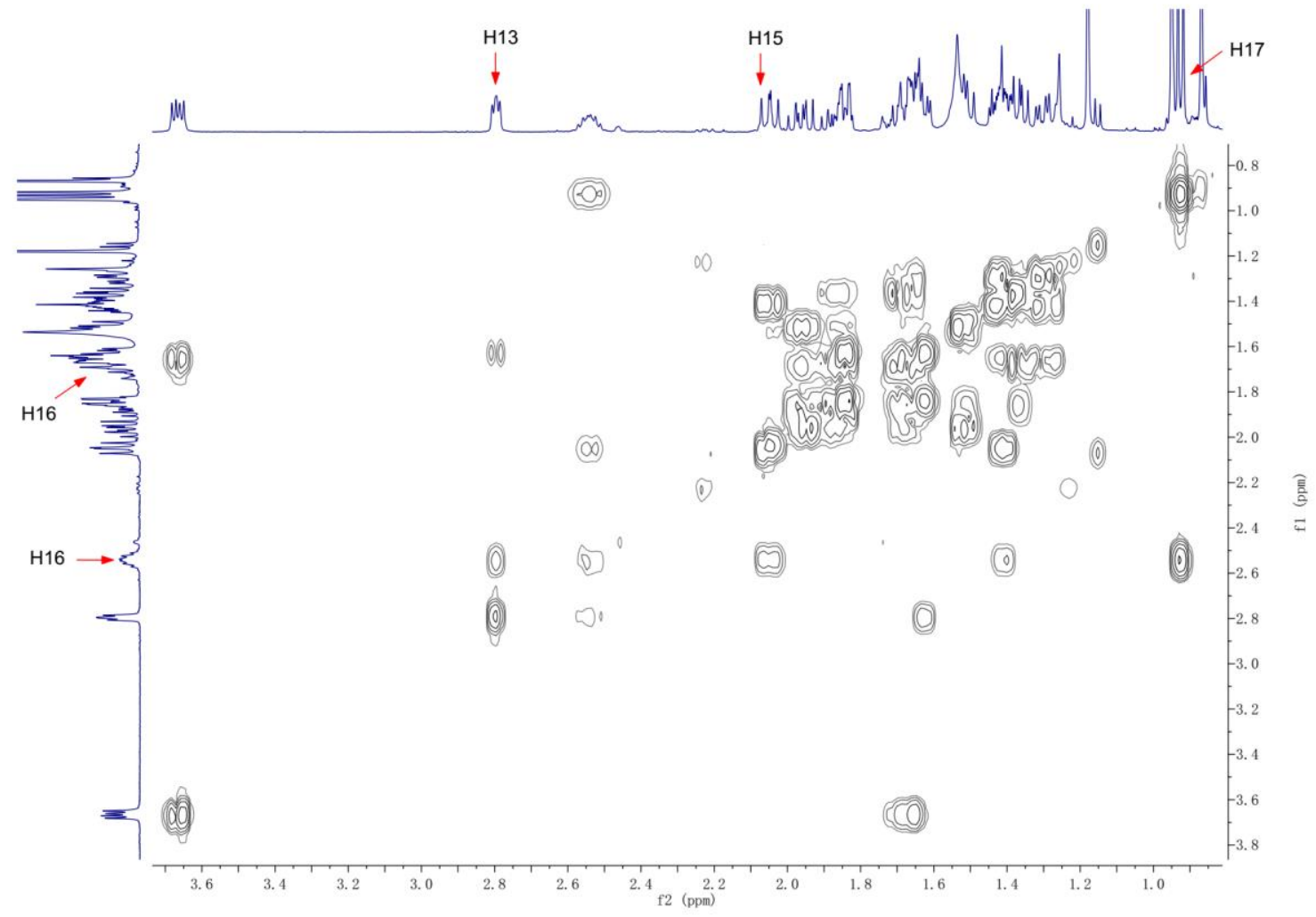

NOESY spectrum of 21'

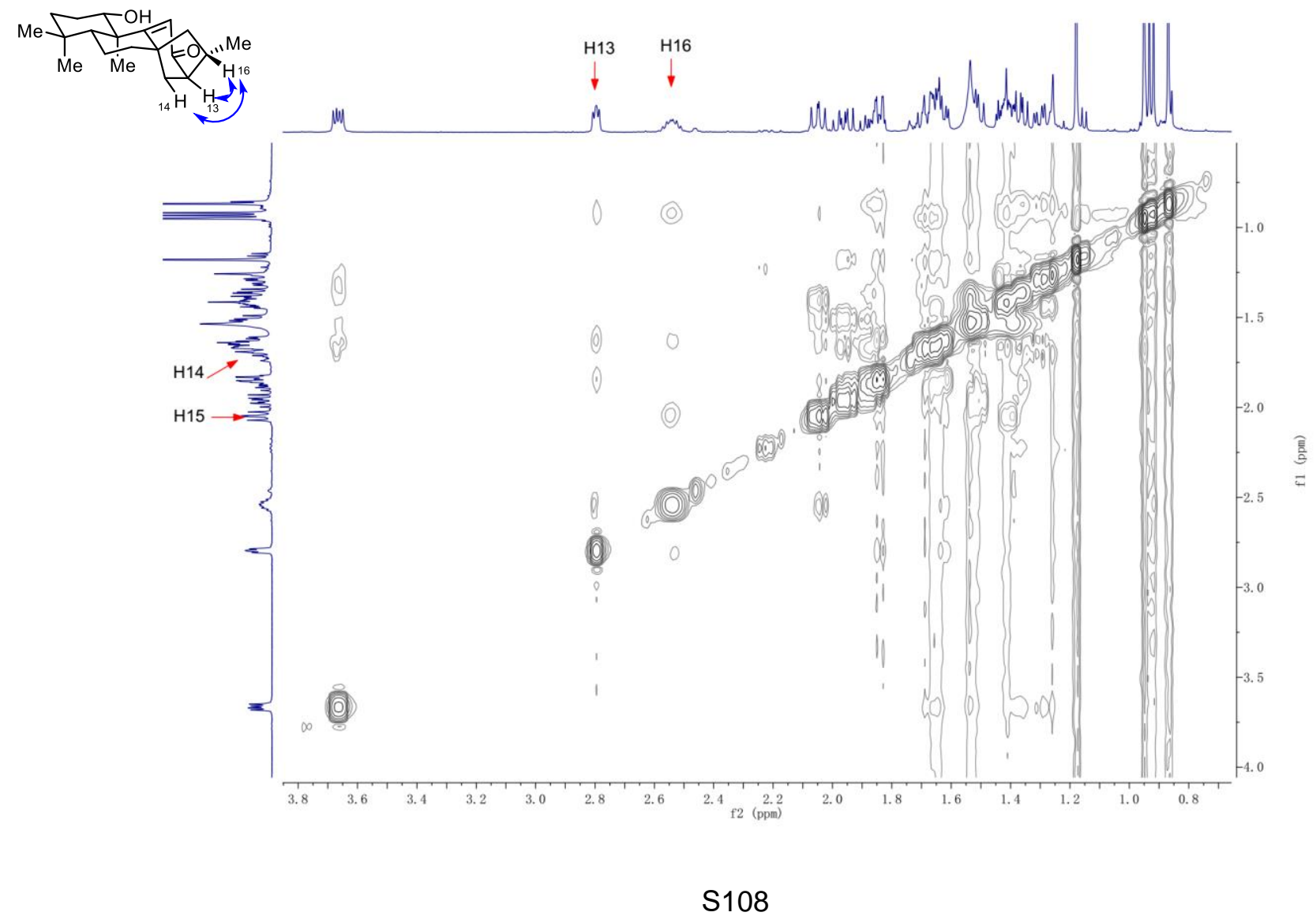




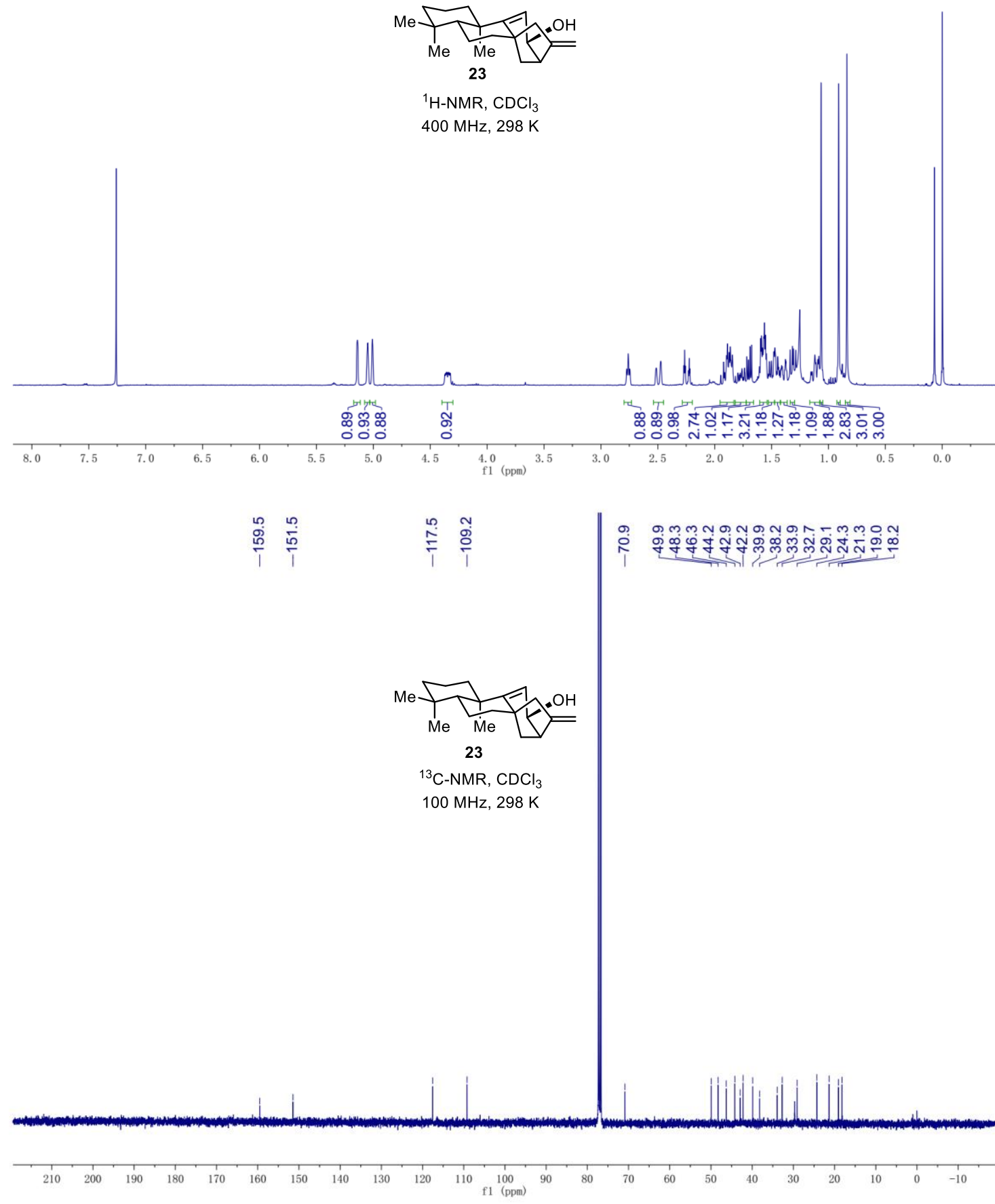


${ }^{1} \mathrm{H}-{ }^{1} \mathrm{H}$ COSY spectrum of 23

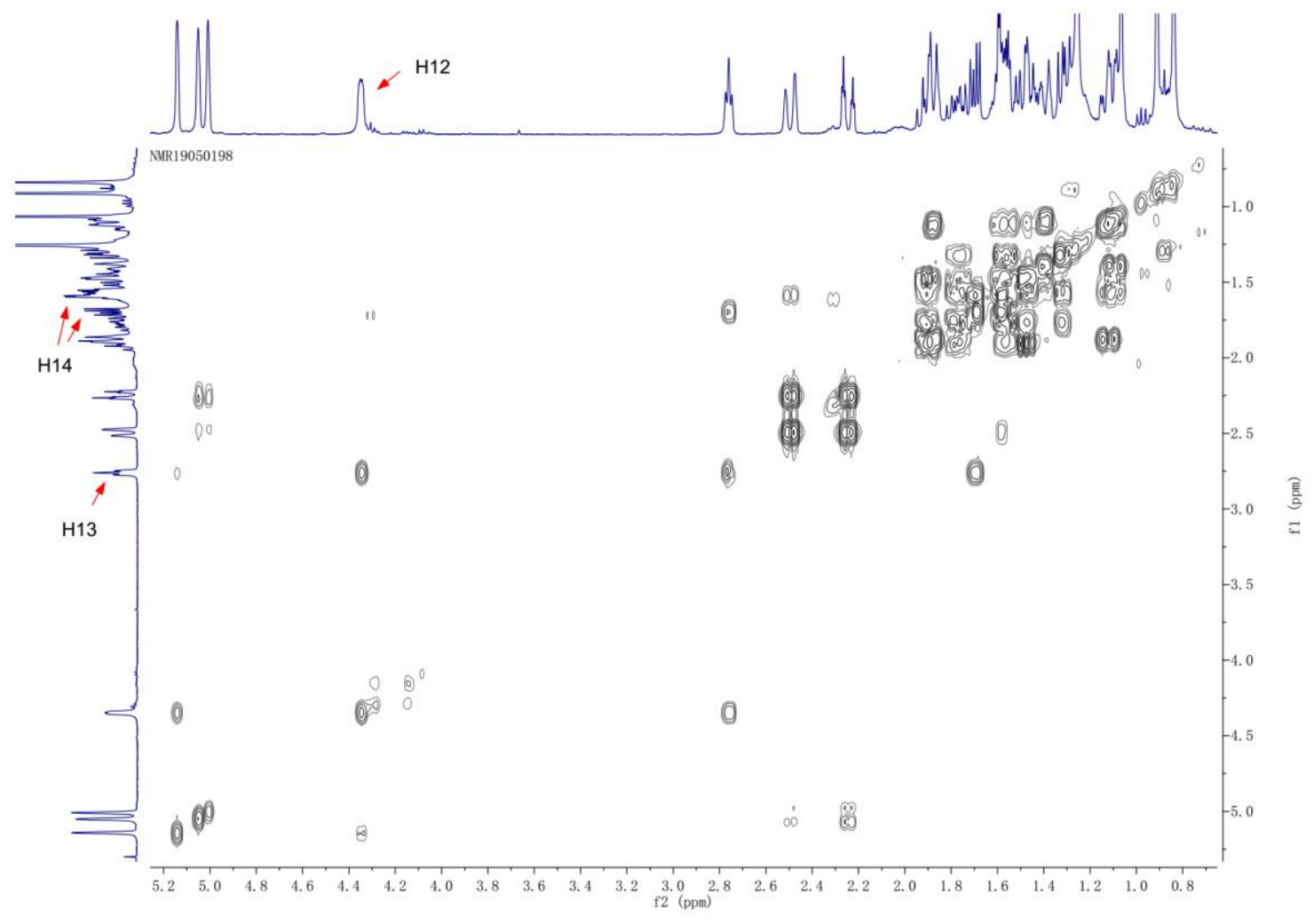

NOESY spectrum of 23

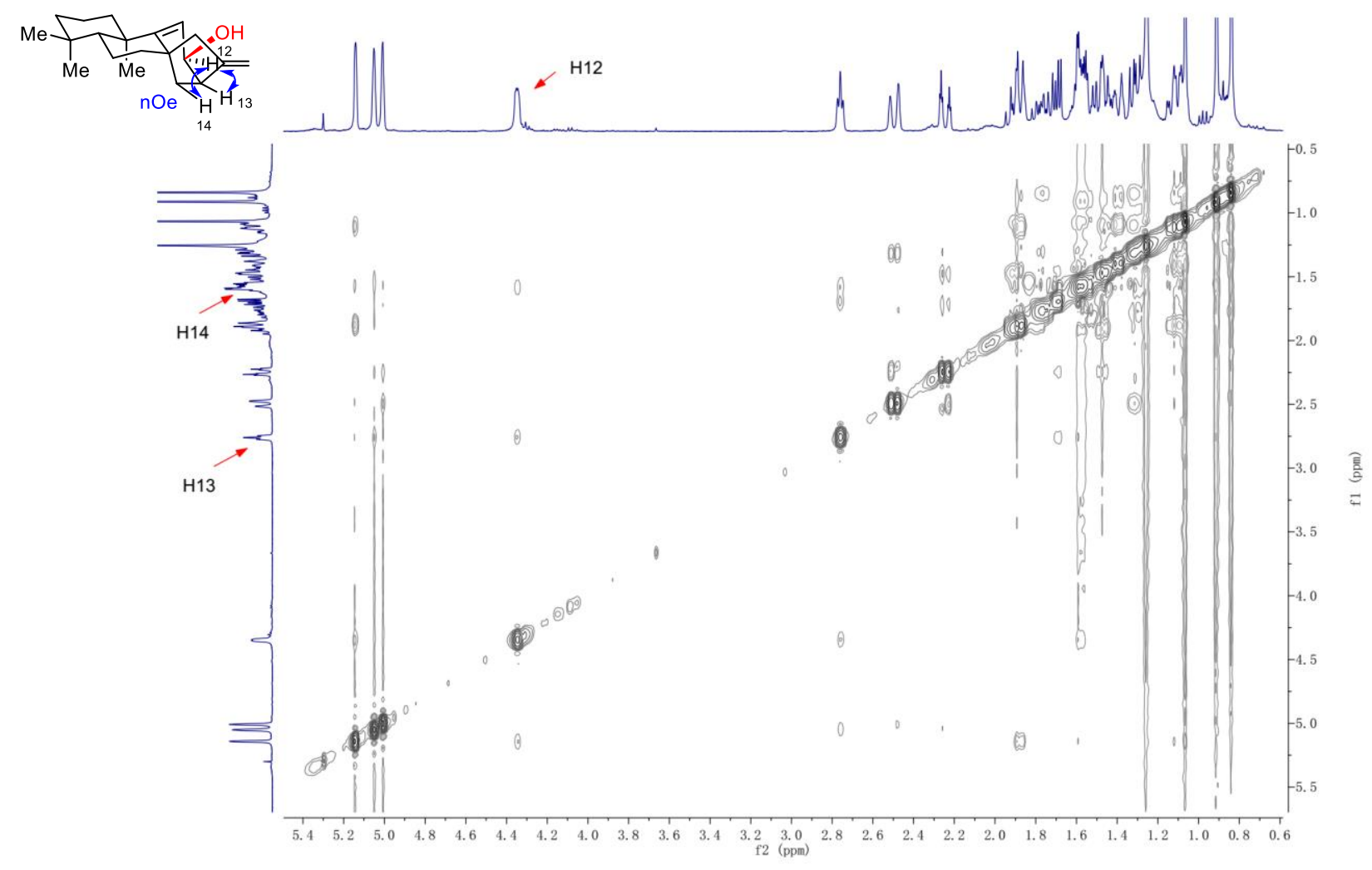




\section{X-Ray crystallographic data}

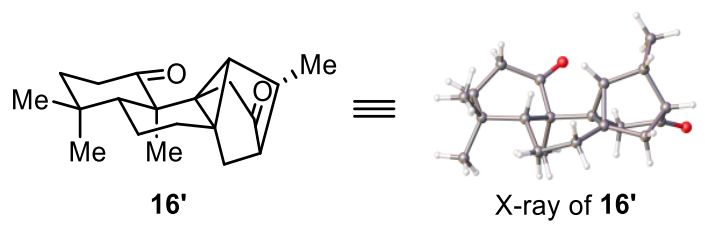

Identification code

CCDC 1972698

Empirical formula

$\mathrm{C}_{20} \mathrm{H}_{28} \mathrm{O}_{2}$

Formula weight

300.42

Temperature/K

293(2)

Crystal system

orthorhombic

Space group

Pbca

a/Å

11.9584(2)

$\mathrm{b} / \AA ̊$

26.4385(7)

$c / \AA$

31.6565(10)

$\alpha /^{\circ}$

90

$\beta /^{\circ}$

90

$\mathrm{Y} /{ }^{\circ}$

90

Volume/ $/ \AA^{3}$

10008.6(4)

Z

24

$\rho_{\text {calc }} \mathrm{g} / \mathrm{cm}^{3}$

1.196

$\mu / \mathrm{mm}^{-1}$

0.075

$F(000)$

3936.0

Crystal size $/ \mathrm{mm}^{3}$

$0.33 \times 0.11 \times 0.02$

Radiation

Mo Ka $(\lambda=0.71073)$

$2 \Theta$ range for data collection/ ${ }^{\circ}$

4.77 to 50.054

Index ranges

$-14 \leq \mathrm{h} \leq 14,-31 \leq \mathrm{k} \leq 27,-37 \leq \mathrm{I} \leq 36$

Reflections collected

63395

Independent reflections

$8758\left[R_{\text {int }}=0.0431, R_{\text {sigma }}=0.0360\right]$

Data/restraints/parameters

$8758 / 0 / 607$

Goodness-of-fit on $\mathrm{F}^{2}$

1.028

Final $R$ indexes $[I>=2 \sigma(I)]$

$\mathrm{R}_{1}=0.0635, \mathrm{wR}_{2}=0.1504$

Final $\mathrm{R}$ indexes [all data]

$\mathrm{R}_{1}=0.0949, \mathrm{wR}_{2}=0.1789$

Largest diff. peak/hole / e $\AA^{-3}$

$0.60 /-0.39$ 

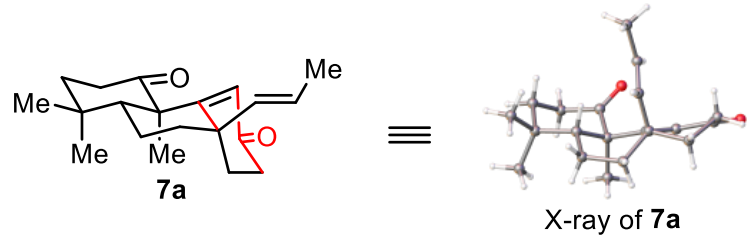

Identification code

CCDC 1959117

Empirical formula

$\mathrm{C}_{20} \mathrm{H}_{28} \mathrm{O}_{2}$

Formula weight

300.42

Temperature/K

180.00(12)

Crystal system

orthorhombic

Space group

Pca21

$\mathrm{a} / \AA ̊ \AA$

12.2894(2)

$\mathrm{b} / \AA ̊ A$

$8.57810(10)$

$c / \AA ̊$

16.1793(2)

$\alpha /^{\circ}$

90

$\beta /^{\circ}$

90

$\mathrm{Y} /{ }^{\circ}$

90

Volume $/ \AA^{3}$

1705.62(4)

Z

4

$\rho_{\text {calc }} / \mathrm{cm}^{3}$

1.170

$\mu / \mathrm{mm}^{-1}$

0.569

$\mathrm{F}(000)$

656.0

Crystal size/ $/ \mathrm{mm}^{3}$

$0.34 \times 0.08 \times 0.04$

Radiation

$\mathrm{Cu} \mathrm{Ka}(\lambda=1.54184)$

$2 \Theta$ range for data collection/ ${ }^{\circ}$

10.312 to 133.156

Index ranges

$-14 \leq \mathrm{h} \leq 11,-10 \leq \mathrm{k} \leq 9,-19 \leq \mathrm{I} \leq 19$

Reflections collected

14636

Independent reflections

$2883\left[R_{\text {int }}=0.0395, R_{\text {sigma }}=0.0298\right]$

Data/restraints/parameters

$2883 / 1 / 203$

Goodness-of-fit on $\mathrm{F}^{2}$

1.057

Final $R$ indexes [ $I>=2 \sigma(I)]$

$\mathrm{R}_{1}=0.0321, w R_{2}=0.0866$

Final $R$ indexes [all data]

$\mathrm{R}_{1}=0.0328, \mathrm{wR}_{2}=0.0873$

Largest diff. peak/hole / e $\AA^{-3}$

$0.15 /-0.15$

Flack parameter

$0.05(13)$ 


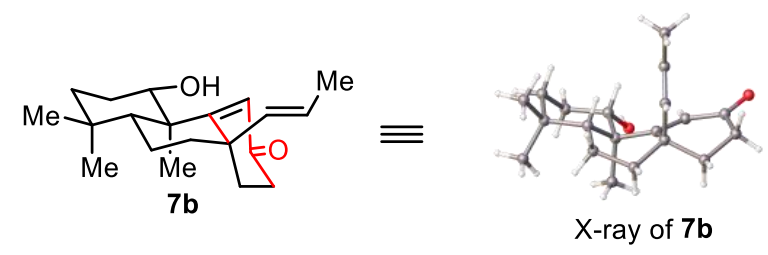

Identification code

Empirical formula

Formula weight

Temperature/K

Crystal system

Space group

a/Å

$\mathrm{b} / \AA$

$\mathrm{c} / \AA$

$\alpha /{ }^{\circ}$

$\beta /^{\circ}$

$\mathrm{y} /{ }^{\circ}$

Volume/ $\AA^{3}$

Z

$\rho_{\text {calc }} \mathrm{g} / \mathrm{cm}^{3}$

$\mu / \mathrm{mm}^{-1}$

$\mathrm{F}(000)$

Crystal size $/ \mathrm{mm}^{3}$

Radiation

$2 \Theta$ range for data collection/ ${ }^{\circ}$

Index ranges

Reflections collected

Independent reflections

Data/restraints/parameters

Goodness-of-fit on $\mathrm{F}^{2}$

Final $R$ indexes $[l>=2 \sigma(I)]$

Final $R$ indexes [all data]

Largest diff. peak/hole / e $\AA^{-3}$
CCDC 1972707

$\mathrm{C}_{20} \mathrm{H}_{30} \mathrm{O}_{2}$

302.44

179.99(14)

triclinic

P-1

$6.5447(2)$

$11.3048(4)$

12.0755(3)

103.670(2)

$90.651(2)$

94.336(3)

865.24(5)

2

1.161

0.561

332.0

$0.16 \times 0.12 \times 0.06$

$\mathrm{Cu} \mathrm{Ka}(\lambda=1.54184)$

7.538 to 133.184

$-7 \leq \mathrm{h} \leq 7,-13 \leq \mathrm{k} \leq 13,-14 \leq \mathrm{I} \leq 14$

7740

3057 [ $\left.R_{\text {int }}=0.0163, R_{\text {sigma }}=0.0207\right]$

$3057 / 0 / 204$

1.084

$\mathrm{R}_{1}=0.0374, w \mathrm{R}_{2}=0.1017$

$\mathrm{R}_{1}=0.0415, \mathrm{wR}_{2}=0.1046$

$0.23 /-0.17$ 


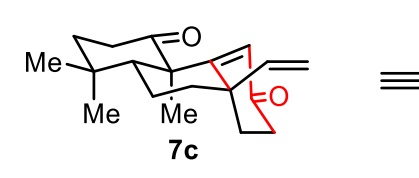

Identification code

Empirical formula

Formula weight

Temperature/K

Crystal system

Space group

a/A

$\mathrm{b} / \AA ̊ \AA$

c/Å

$\alpha /{ }^{\circ}$

$\beta /{ }^{\circ}$

$\gamma /^{\circ}$

Volume/ $/ \AA^{3}$

Z

$\rho_{\text {calc }} / \mathrm{cm}^{3}$

$\mu / \mathrm{mm}^{-1}$

$\mathrm{F}(000)$

Crystal size $/ \mathrm{mm}^{3}$

Radiation

$2 \Theta$ range for data collection ${ }^{\circ}$

Index ranges

Reflections collected

Independent reflections

Data/restraints/parameters

Goodness-of-fit on $F^{2}$

Final $R$ indexes $[I>=2 \sigma(I)]$

Final $R$ indexes [all data]

Largest diff. peak/hole / e $\AA^{-3}$

Flack parameter

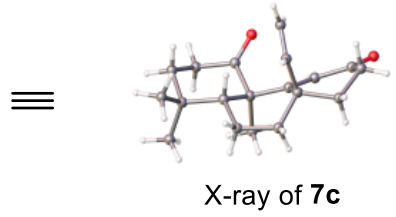

CCDC 1972699

$\mathrm{C}_{19} \mathrm{H}_{26} \mathrm{O}_{2}$

286.40

179.99(10)

orthorhombic

P212121

8.8797(3)

11.8527(4)

14.9997(5)

90

90

90

1578.69(9)

4

1.205

0.076

624.0

$0.35 \times 0.24 \times 0.19$

Mo Ka $(\lambda=0.71073)$

5.332 to 54.966

$-11 \leq \mathrm{h} \leq 11,-15 \leq \mathrm{k} \leq 14,-15 \leq \mathrm{I} \leq 19$

10392

$3628\left[R_{\text {int }}=0.0308, R_{\text {sigma }}=0.0342\right]$

$3628 / 0 / 193$

1.033

$\mathrm{R}_{1}=0.0352, \mathrm{wR}_{2}=0.0939$

$\mathrm{R}_{1}=0.0392, \mathrm{wR}_{2}=0.0960$

$0.20 /-0.17$

$0.8(5)$ 


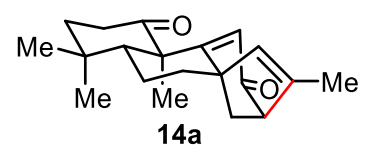

Identification code

Empirical formula

Formula weight

Temperature/K

Crystal system

Space group

$\mathrm{a} / \AA$

$\mathrm{b} / \AA ̊ \AA$

c/Å

$\alpha /^{\circ}$

$\beta /^{\circ}$

$\mathrm{Y}^{\circ}$

Volume $/ \AA^{3}$

Z

$\rho_{\text {calc }} \mathrm{g} / \mathrm{cm}^{3}$

$\mu / \mathrm{mm}^{-1}$

$\mathrm{F}(000)$

Crystal size $/ \mathrm{mm}^{3}$

Radiation

$2 \Theta$ range for data collection $/{ }^{\circ}$

Index ranges

Reflections collected

Independent reflections

Data/restraints/parameters

Goodness-of-fit on $\mathrm{F}^{2}$

Final $R$ indexes $[I>=2 \sigma(I)]$

Final $R$ indexes [all data]

Largest diff. peak/hole / e $\AA^{-3}$

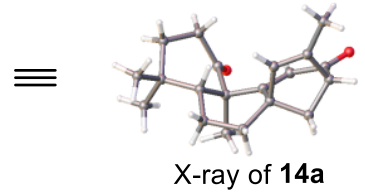

CCDC 1951764

$\mathrm{C}_{20} \mathrm{H}_{26} \mathrm{O}_{2}$

298.41

180.01(10)

monoclinic

$\mathrm{P} 21 / \mathrm{c}$

20.5218(4)

11.9368(2)

$13.4260(2)$

90

93.652(2)

90

3282.22(10)

8

1.208

0.591

1296.0

$0.45 \times 0.24 \times 0.18$

$\mathrm{Cu} \mathrm{Ka}(\lambda=1.54184)$

8.574 to 149.872

$-25 \leq \mathrm{h} \leq 22,-11 \leq \mathrm{k} \leq 14,-16 \leq \mathrm{I} \leq 16$

12645

$6561\left[R_{\text {int }}=0.0217, R_{\text {sigma }}=0.0293\right]$

$6561 / 0 / 405$

1.045

$\mathrm{R}_{1}=0.0556, \mathrm{wR}_{2}=0.1521$

$\mathrm{R}_{1}=0.0647, \mathrm{wR}_{2}=0.1594$

$0.70 /-0.37$ 


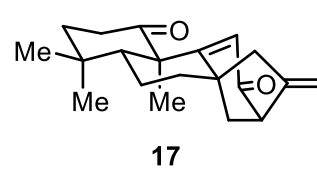

Identification code

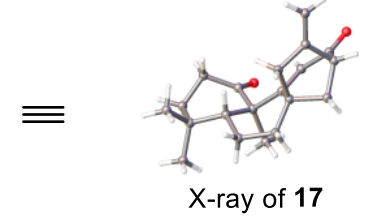

Empirical formula

CCDC 1951765

Formula weight

$\mathrm{C}_{20} \mathrm{H}_{26} \mathrm{O}_{2}$

Temperature/K

298.41

Crystal system

179.99(10)

monoclinic

Space group

$\mathrm{P} 2{ }_{1} / \mathrm{c}$

$\mathrm{a} / \AA$

7.9564(4)

b/Å

8.9245(5)

c/Å

23.0248(10)

$\alpha /^{\circ}$

90

$\beta /^{\circ}$

96.003(4)

$\gamma^{\circ}$

90

Volume/ $\AA^{3}$

1625.95(14)

Z

4

$\rho_{\text {calc }} \mathrm{g} / \mathrm{cm}^{3}$

1.219

$\mu / \mathrm{mm}^{-1}$

0.077

$\mathrm{F}(000)$

648.0

Crystal size $/ \mathrm{mm}^{3}$

$0.34 \times 0.11 \times 0.08$

Radiation

Mo Ka $(\lambda=0.71073)$

$2 \Theta$ range for data collection/ ${ }^{\circ}$

3.558 to 54.968

Index ranges

$-10 \leq h \leq 10,-11 \leq k \leq 10,-28 \leq \mathrm{I} \leq 29$

Reflections collected

11647

Independent reflections

$3738\left[R_{\text {int }}=0.0459, R_{\text {sigma }}=0.0529\right]$

Data/restraints/parameters

$3738 / 0 / 202$

Goodness-of-fit on $\mathrm{F}^{2}$

1.002

Final $R$ indexes $[I>=2 \sigma(I)]$

$R_{1}=0.0546, w R_{2}=0.1388$

Final $\mathrm{R}$ indexes [all data]

$\mathrm{R}_{1}=0.0722, \mathrm{wR}_{2}=0.1497$

Largest diff. peak/hole / e $\AA^{-3}$

$0.59 /-0.29$ 


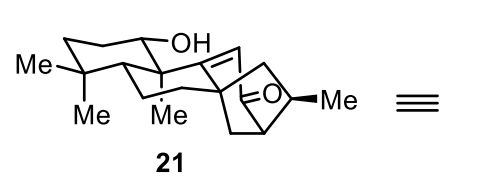

Identification code

Empirical formula

Formula weight

Temperature/K

Crystal system

Space group

$\mathrm{a} / \AA$

$\mathrm{b} / \AA ̊ \AA$

c/Å

$\alpha /{ }^{\circ}$

$\beta /^{\circ}$

$\gamma /{ }^{\circ}$

Volume/ $\AA^{3}$

Z

$\rho_{\text {calc }} / \mathrm{cm}^{3}$

$\mu / \mathrm{mm}^{-1}$

$\mathrm{F}(000)$

Crystal size $/ \mathrm{mm}^{3}$

Radiation

$2 \Theta$ range for data collection/ ${ }^{\circ}$

Index ranges

Reflections collected

Independent reflections

Data/restraints/parameters

Goodness-of-fit on $\mathrm{F}^{2}$

Final $R$ indexes $[l>=2 \sigma(I)]$

Final $\mathrm{R}$ indexes [all data]

Largest diff. peak/hole / e $\AA^{-3}$

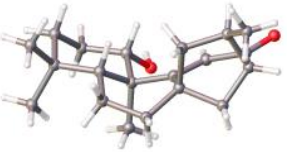

X-ray of 21

CCDC 1951825

$\mathrm{C}_{20} \mathrm{H}_{30} \mathrm{O}_{2}$

302.44

179.99(10)

triclinic

P-1

7.0073(3)

11.0777(4)

12.3625(6)

114.095(4)

94.197(4)

97.996(3)

858.49(7)

2

1.170

0.073

332.0

$0.37 \times 0.24 \times 0.13$

Mo Ka $(\lambda=0.71073)$

5.932 to 54.954

$-9 \leq h \leq 9,-14 \leq k \leq 14,-16 \leq \mathrm{I} \leq 16$

10054

$3915\left[R_{\text {int }}=0.0313, R_{\text {sigma }}=0.0396\right]$

$3915 / 0 / 204$

1.047

$R_{1}=0.0520, w R_{2}=0.1451$

$\mathrm{R}_{1}=0.0638, \mathrm{wR}_{2}=0.1529$

$0.38 /-0.22$ 


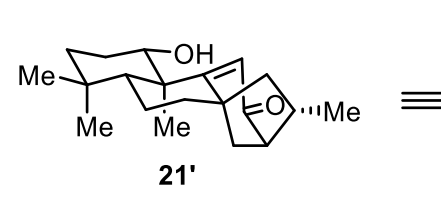

Identification code

Empirical formula

Formula weight

Temperature/K

Crystal system

Space group

$\mathrm{a} / \AA$

$\mathrm{b} / \AA$

C/Å

$\alpha /{ }^{\circ}$

$\beta /^{\circ}$

$\gamma /{ }^{\circ}$

Volume $/ \AA^{3}$

Z

$\rho_{\text {calc }} / \mathrm{cm}^{3}$

$\mu / \mathrm{mm}^{-1}$

$F(000)$

Crystal size $/ \mathrm{mm}^{3}$

Radiation

$2 \Theta$ range for data collection ${ }^{\circ}$

Index ranges

Reflections collected

Independent reflections

Data/restraints/parameters

Goodness-of-fit on $F^{2}$

Final $R$ indexes $[I>=2 \sigma(I)]$

Final $\mathrm{R}$ indexes [all data]

Largest diff. peak/hole / e $\AA^{-3}$

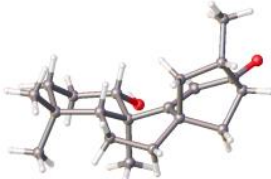

X-ray of 21'

CCDC 1951826

$\mathrm{C}_{20} \mathrm{H}_{30} \mathrm{O}_{2}$

302.44

$180.00(10)$

monoclinic

$\mathrm{P} 2{ }_{1} / \mathrm{c}$

20.4927(5)

13.2198(3)

12.8593(3)

90

102.596(2)

90

3399.86(14)

8

1.182

0.074

1328.0

$0.24 \times 0.22 \times 0.18$

$\operatorname{Mo~Ka~}(\lambda=0.71073)$

4.614 to 54.968

$-26 \leq \mathrm{h} \leq 26,-17 \leq \mathrm{k} \leq 15,-16 \leq \mathrm{I} \leq 16$

27165

$7778\left[R_{\text {int }}=0.0361, R_{\text {sigma }}=0.0420\right]$

$7778 / 0 / 407$

1.058

$R_{1}=0.0485, w R_{2}=0.1279$

$\mathrm{R}_{1}=0.0687, \mathrm{wR}_{2}=0.1381$

$0.35 /-0.27$ 


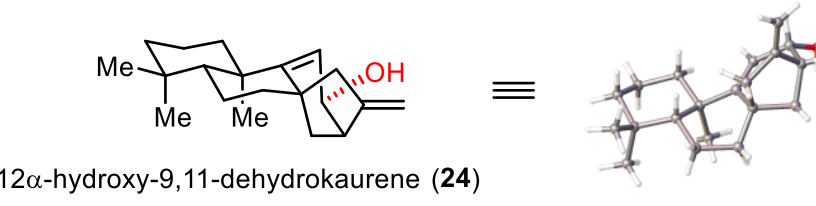

X-ray of $\mathbf{2 4}$

Identification code

Empirical formula

Formula weight

Temperature/K

Crystal system

Space group

$\mathrm{a} / \AA$

$b / \AA$

c/Å

$\alpha /^{\circ}$

$\beta /^{\circ}$

$\gamma /^{\circ}$

Volume $/ \AA^{3}$

Z

$\rho_{\text {calc }} \mathrm{g} / \mathrm{cm}^{3}$

$\mu / \mathrm{mm}^{-1}$

$\mathrm{F}(000)$

Crystal size $/ \mathrm{mm}^{3}$

Radiation

$2 \Theta$ range for data collection $/{ }^{\circ}$

Index ranges

Reflections collected

Independent reflections

Data/restraints/parameters

Goodness-of-fit on $\mathrm{F}^{2}$

Final $R$ indexes $[I>=2 \sigma(I)]$

Final $\mathrm{R}$ indexes [all data]

Largest diff. peak/hole / e $\AA^{-3}$
CCDC 1951766

$\mathrm{C}_{20} \mathrm{H}_{30} \mathrm{O}$

286.44

179.99(10)

tetragonal

$\mathrm{P} 4{ }_{2} / \mathrm{n}$

20.9667(3)

20.9667(3)

7.7032(3)

90

90

90

3386.35(16)

8

1.124

0.066

1264.0

$0.57 \times 0.035 \times 0.03$

Mo Ka $(\lambda=0.71073)$

5.496 to 54.944

$-27 \leq \mathrm{h} \leq 21,-24 \leq \mathrm{k} \leq 27,-10 \leq \mathrm{I} \leq 9$

23661

$3868\left[R_{\text {int }}=0.0457, R_{\text {sigma }}=0.0413\right]$

$3868 / 0 / 194$

1.066

$\mathrm{R}_{1}=0.0516, \mathrm{wR}_{2}=0.1133$

$\mathrm{R}_{1}=0.0736, \mathrm{wR}_{2}=0.1220$

$0.21 /-0.17$ 


\section{References}

1. Alexakis, A.; Frutos, J. C.; Mangeney, P. A easy and fast way to determine the enatiomeric purity of substituted cyclanones. Tetrahedron: Asymmetry 1993, 4, 2431-2434.

2. Maksymowicz, R. M.; Roth, P. M. C.; Fletcher, S. P. Catalytic asymmetric carbon-carbon bond formation using alkenes as alkylmetal equiva-lents. Nat. Chem. 2012, 4, 649-654.

3. Wu, J.; Kadonaga, Y.; Hong, B.; Wang, J.; Lei, X. Enantioselective total synthesis of (+)jungermatrobrunin A. Angew. Chem., Int. Ed. 2019, 58, 10879-10883

4. Lorimer, S. D.; Perry, N. B.; Burgess, E. J.; Foster, L. M. 1-Hydroxyditerpenes from two New Zealand liverworts, paraschistochila pinnatifolia and trichocolea mollissima. J. Nat. Prod. 1997, 60, 421-424.

5. The literature (Ref. 4: J. Nat. Prod. 1997, 60, 421-424.) doesn't give the spectra of 12a-hydroxy9,11-dehydrokaurene (2).

6. Pinto, A. C.; Prado, S. K.; Pinchin, R. Two kaurenes from Vellozia caput-ardeae. Phytochemistry $1981,20,520-521$. This isolated paper only reported several proton NMR data.

7. The literature (Ref. 6: Phytochemistry 1981, 20, 520-521.) doesn't give the spectra of 12-oxo9,11-dehydrokaurene (22).

8. This is the active proton of $\mathrm{C} 12-\mathrm{OH}$

9. The literature (Ref. 6: Phytochemistry 1981, 20, 520-521.) doesn't give the spectra of 12ahydroxy-9,11-dehydrokaurene (24).

10. Boeckman, Jr. R. K.; Breining, S. R. Molecular Cascades. 1. Tandem Cyclopropyl Iminium Ion Rearrangement-[4+2] Cycloaddition Reactions. Tetrahedron. 1997, 53, 8941-8962.

11. Paquette, L, O.; Oplinger, J. A. Limitations in the application of anionic oxy-cope sigmatropy to elaboration of the forskolin nucleus. Tetrahedron 1989, 45, 107-124. 